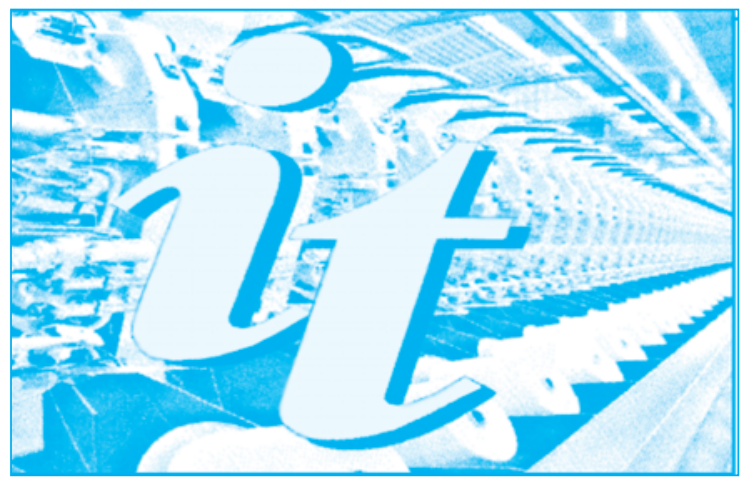

ISI rated journal, included in the ISI Master Journal List of the Institute of Science Information, Philadelphia, USA, starting with vol. 58, no. 1/2007, with impact factor 0.504 and AIS 0.046 in 2018

The journal is indexed by CrossRef, starting with no. 1/2017 having the title DOI: https://doi.org/10.35530/IT.

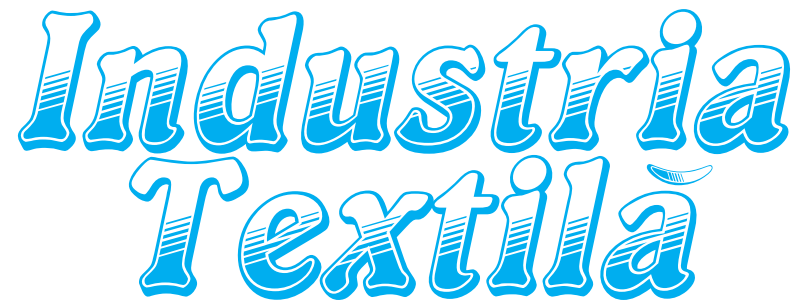

ISSN $1222-5347$

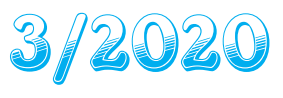

Edited in 6 issues per year, indexed and abstracted in: Science Citation Index Expanded $\left(\right.$ SciSearch $\left.^{\circledR}\right)$, Materials Science Citation Index ${ }^{\circledR}$, Journal Citation Reports/Science Edition, World Textile Abstracts, Chemical Abstracts, VINITI, Scopus, Toga FIZ technik ProQuest Central, Crossref

Edited with the Romanian Ministry of Education and Research support

\section{INIDUSTRIA TEXTILA EIDITDIRIAL BDARID:}

Dr. Eng. CARMEN GHITULEASA GENERAL MANAGER

National R\&D Institute for Textiles and Leather Bucharest, Romania

Dr. Eng. SABINA OLARU CS II, EDITOR IN CHIEF

National R\&D Institute for Textiles and Leather, Bucharest, Romania

Dr. Eng. EMILIA VISILEANU

National R\&D Institute for Textiles and Leather, Bucharest, Romania Prof. XIANYI ZENG

Ecole Nationale Superieure des Arts et Industries Textiles (ENSAIT), France

Prof. Dr. Eng. LUIS ALMEIDA University of Minho, Portugal

Prof. Dr. STJEPANOVIČ ZORAN University of Maribor, Faculty of Mechanical Engineering, Department of Textile Materials and Design, Maribor, Slovenia Lec. ALEXANDRA DE RAEVE University College Ghent, Fashion, Textile and Wood Technology Department, Belgium

Prof. Dr. Eng. ERHAN ÖNER

Marmara University, Turkey

Prof. Dr. S. MUGE YUKSELOGLU

Marmara University, Turkey

$$
\text { Dr. MAZARI ADNAN }
$$

ASSISTANT PROFESSOR

Department of Textile Clothing, Faculty of Textile Engineering, Technical University of Liberec Czech Republic Dr. AMINODDIN HAJI

$P h D, M S c, B S c$, Textile Chemistry and Fiber Science ASSISTANT PROFESSOR

Textile Engineering Department

Yazd University, Yazd, Iran

Prof. Dr. Eng. CARMEN LOGHIN PRO-RECTOR

Faculty of Industrial Design and Business Management, Technical University

"Gh. Asachi”, laşi, Romania

Associate Prof. Dr. Eng. MARIANA URSACHE DEAN

Faculty of Industrial Design and Business Management, Technical University "Gh. Asachi", laşi, Romania

Prof. Dr. GELU ONOSE CSI

"Carol Davila" University of Medicine and Pharmacy, Bucharest, Romania

Prof. Dr. DOINAI. POPESCU

The Bucharest University of Economic Studies, Bucharest, Romania

Prof. Dr. MARGARETA STELEA FLORESCU

The Bucharest University of Economic Studies, Bucharest, Romania
FUNDA BUYUK MAZARI, ADNAN MAZARI, ADNAN CIRKL,

ANTONIN HAVELKA

Comparison of different interlining materials of car seat cover under

repeated loadings

199-203

SHAO FEN-JUAN, XU PINGHUA, FAN WEICHAO, YAN YULONG, DING XUEMEI,

WU XIONGYING

Evaluation of stain release based on image histogram analysis

JIA-HONG QIAN, YU-YING QIU, YI-DUO YANG, YI LI, PING-HUA XU, LAI-LI WANG Accounting and evaluation of chemical footprint of cotton woven fabrics

ABDULLAH EJAZ, RAMONA BIRAU, CRISTI SPULBAR, RAMONA BUDA, ANDREI COSMIN TENEA

The impact of domestic portfolio diversification strategies in Toronto stock exchange on Canadian textile manufacturing industry

POLONA DOBNIK DUBROVSKI

Breaking force analysis of cotton ring-spun yarns

SHUMAILA KIRAN, SHAHID ADEEL, MUHAMMAD SAJJAD YOUSAF, NOMAN HABIB, ATYA HASSAN, MUHAMMAD ABDUL QAYYUM,

\section{MUHAMMAD ABDULLAH}

Green dyeing of microwave treated silk using coconut coir based tannin natural dye

YULIIA MELNYCHUK, IRYNA TKACHUK, LIUDMYLA CHVERTKO, MAKSYM SLATVINSKYI, OKSANA VINNYTSKA, TETIANA KORNIIENKO Assessment of financial and investment activity of textile enterprises as a guarantee of successful business in the region

TIRSO JAVIER HERNÁNDEZ-GRACIA, DANAE DUANA-AVILA

Creators of competitiveness in the textile and clothing industry from

the Hidalgo state

DENISA BOGDANA ABRUDAN, MĂDĂLINA DUMITRITA MATICIUC, MARIAN NĂSTASE, MARGARETA STELA FLORESCU,'DANA CODRUȚA DĂIANU The challenge of young Romanian designers: creativity in business

IULIANA DUMITRESCU, OVIDIU-GEORGE IORDACHE, CORNELIA-ELENA MITRAN, ELENA PERDUM, IRINA-MARIANA SĂNDULACHE, LUCIA OANA SECĂREANU, LAURENTIU CHRISTIAN DINCĂ, ARCADII SOBETKII, LUCIAN DIAMANDESCU Attempts to improve the self-cleaning effect of the textile materials

LUCIA OANA SECĂREANU, CORNELIA-ELENA MITRAN,

IRINA-MARIANA SĂNDULACHE, MIHAELA-CRISTINA LITE, ELENA PERDUM, OVIDIU-GEORGE IORDACHE

Validation method and proficiency test for the determination of free and hydrolysed formaldehyde

KALKANCI MIHRIBAN

Investigation of surface defects and apparel manufacturing efficiency of fabrics woven from recycled cotton and blends

INETA VILUMSONE-NEMES, DANA BELAKOVA

Reduction of material consumption for garments from checked fabrics

LI BIN, ZHAO HONGYAN, LI YIXIAO, JIANG XUEWEI, HONG YU, TAO HU

Study on the origin and evolution of the Chinese batik

MIHAI CRISTIAN ORZAN, MARGARETA STELA FLORESCU,

OCTAV IONUT MACOVEI, SORIN BURLACU, OLGUTA ANCA ORZAN

The effects of online marketing on financial performance in the textile industry

$288-293$ 


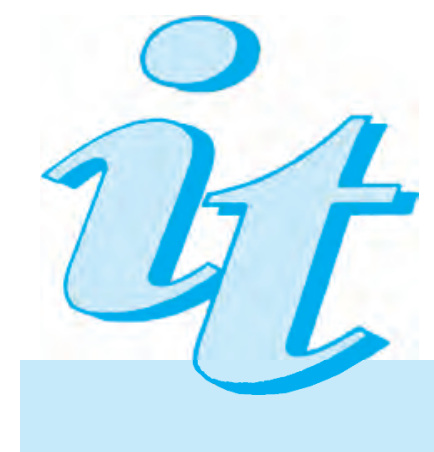

Scientific reviewers for the papers published in this number:

Assoc. Prof. Deborah Beard, Chair of Technical Design, Fashion Institute of Technology, New York, USA

Assit. Prof. Catalin Macarie, Carl H. Lindner College of Business, University of Cincinnati, USA

Assist. Prof. Qi Han, Deakin University, Australia

Prof. Kjartan Sigurdsson, Reykjavik University, Iceland

Assoc. Prof. PhD Anita Tarbuk, University of Zagreb, Faculty of Textile Technology, Croatia

Prof. Dr. Stana Kovačević, University of Zagreb, Faculty of Textile Technology, Croatia

Prof. Dr. Elsayed Ahmed Elnashar, Kafrelsheikh University, Faculty of Specific Education, Egypt

$P h D$. Dagoberto Torres Florez, Los Llanos University, Colombia

Dr. Marina Sierra, Universidad Paulo de Santander, Colombia

Prof. Univ. Dr. Doina I. Popescu, Bucharest University of Economic Studies, Romania

Assist. Prof. Dr. Aminoddin Haji, Yazd University, Textile Engineering Department, Iran

Dr. Rym Mansour, Unit of Textile research ISAM Kairouan, Tunisia

Assoc. Prof. Hakan Ozdemir, Dokuz Eylül University, Department of Textile Engineering, Turkey

Assoc. Prof. Zümrüt Bahadır Ünal, Ege University, Department of Textile Engineering, Turkey

Dr. Gordana Colovic, The College of Textile Design, Technology and Management, Serbia

Dr. Danijela Paunovic, The College of Textile Design, Technology and Management, Serbia

Dr. Usman Javaid, National Textile University, Pakistan

Dr. Memik Bunyamin Uzumcu, Gaziantep University, Turkey

Assoc. Prof. Dr. Jatin Trivedi, Amity University Mumbai, Faculty of Finance, India

Dr. Zlatina Kazlacheva, Trakia University, Faculty of Technics and Technologies, Bulgaria

Prof. PhD. Ivana Kovacevic, University of Belgrade, Serbia

Prof. Dr. Aurelia Litvin, State Agrarian University of Moldova, Department of Business and Aministration, Moldova Republic

\begin{tabular}{|c|}
\hline EDITORIAL STAFF \\
General Manager: Dr. Eng. Carmen Ghițuleasa \\
Editor-in-chief: Dr. Eng. Sabina Olaru \\
Onorific editor: Dr. Eng. Emilia Visileanu \\
Graphic designer: Florin Prisecaru \\
Translator: Cătălina Costea \\
Site administrator: Constantin Dragomir \\
e-mail: industriatextila@incdtp.ro \\
\hline
\end{tabular}

INDUSTRIA TEXTILA journal, edited by INCDTP BUCHAREST, implements and respects Regulation 2016/679/EU on the protection of individuals with regard to the processing of personal data and on the free movement of such data ("RGPD"). For information, please visit the Personal Data Processing Protection Policy link or e-mail to DPO rpd@incdtp.ro

Journal edited in colaboration with Editura AGIR, 118 Calea Victoriei, sector 1, Bucharest, tel./fax: 021-316.89.92; 021-316.89.93; e-mail: editura@agir.ro,www.edituraagir.ro 


\title{
Comparison of different interlining materials of car seat cover under repeated loadings
}

\author{
DOI: $10.35530 / 1 T .071 .03 .1704$
}

\section{ABSTRACT - REZUMAT}

\section{Comparison of different interlining materials of car seat cover under repeated loadings}

In this article, four most commonly used interlining materials (3D spacer fabric, non-woven felt, reticulated foam, and classic Poly-Urethane foam) are tested for comfort and durability. All four layers are tested initially for the air and moisture permeability, then for water vapour permeability under loading and finally tested for compressibility and durability. The repeated loading equivalent to real human pressure was inserted on the samples for 40,000 times to analyse the effect of repeated compression on the interlining materials. This research work gives a very in-depth knowledge of performance of car seat interlining material related to thermophysiological comfort and durability/lifetime.

Keywords: $3 D$ spacer fabric, compressibility, thermophysiological comfort

\section{Analiza comparativă a diferitelor inserții pentru husele scaunelor auto aflate sub solicitări repetate}

În acest articol, patru materiale de tip inserție utilizate cel mai frecvent (material distanțier 3D, material nețesut, spumă reticulată și spumă clasică din poliuretan) au fost testate din punctul de vedere al confortului și durabilității. Toate cele patru straturi au fost testate inițial din punctul de vedere al permeabilității la aer și vapori de apă, apoi din punctul de vedere al permeabilității la vapori de apă sub greutate și în final au fost testate din punctul de vedere al compresibilității și durabilității. Solicitarea repetată echivalentă cu presiunea umană reală a fost introdusă pe eșantioane de 40.000 de ori, pentru a analiza influența compresiei repetate asupra inserțiilor. Această lucrare de cercetare oferă o cunoaștere aprofundată a performanței inserțiilor pentru scaunele auto, din punctul de vedre al confortului termofiziologic și durabilității/duratei de viață.

Cuvinte-cheie: material distanțier 3D, compresibilitate, confort termofiziologic

\section{INTRODUCTION}

Generally, car seats are composed of the following elements:

- Metal structure;

- Filling, cushion padding;

- Seat cover:

- Exterior fabric;

- Foam (interlining);

- Support material (reinforcement material) [1-2]. The parts of the car seat in cross-section view are shown in figure 1.

On the top of metal frame, the most common filling material as a cushion is molded polyurethane foam. Polyurethane foam is commonly used as padding in car seats despite some problems concerning comfort and recycling. Their thermal properties are poor because they are not breathable [2]. Because of this problem, a lot of research has been made and today the new developments and the testing are going on to improve the thermal comfort of the car seats

Unlike regular, 2D fabrics, Spacer uses two separate fabrics, joined by microfilament yarn, to create a breathable, 3D free space between layers [3] as shown in figure 2.

Spacer textiles in upholstery are made from warp knitted (double-Raschel machine) or knitted (circular knitting machine) fabrics. Spacer structures have an

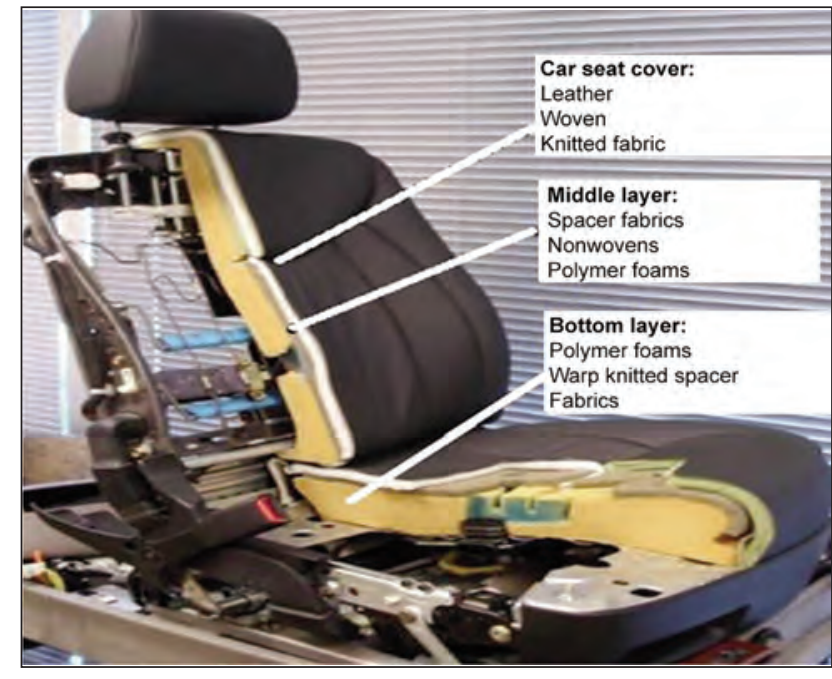

Fig. 1. The parts of the classical car seat [1-2]

elastic pressure behavior: by pressing on the surface they are compressed. When the pressure is released, they relax in an elastic way. The space between the two layers is an air-filled cavity from which the air is removed during compression, and into which air is sucked during decompression. Unlike foam constructions, these textile constructions are able to breathe [4-7]. 


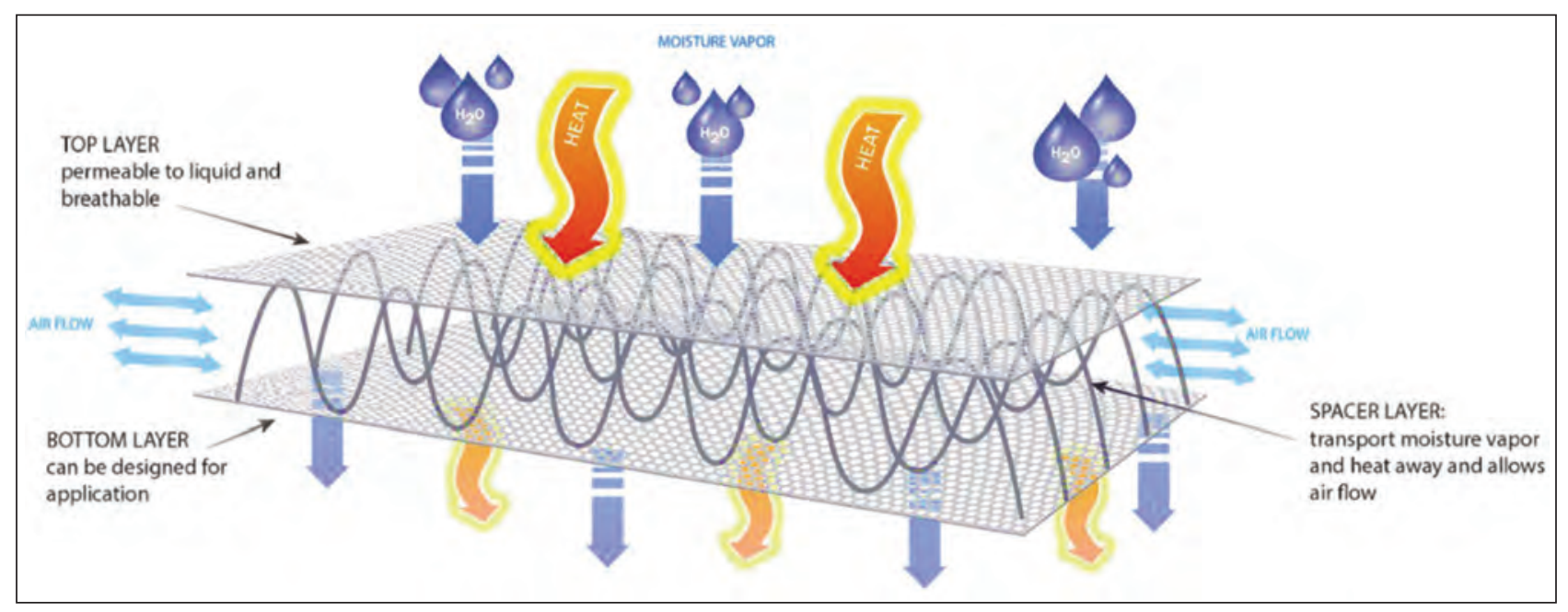

Fig. 2. 3D Spacer Knitted Fabric Schematic design [3]

For the car seat cover on the top of the cushion part of the car seat, many manufacturers find that a threelayer composite fabric is most successful in performance, costing, and in the process of upholstering or trimming the seat. The most common three layers are composed of a top layer which is polyester and a middle layer of polyurethane foam. The foam, varies from 3 millimeters to $12 \mathrm{~mm}$, and it has function of absorbing the seat surface irregularities, improves the comfort (compressibility, resilience) and indicates the stitches of the sewing lines with an adequate depth [8]. The bottom layer is composed by a polyamide knitted scrim [9]. Knit Scrim material has the task to give the dimensional stability to sandwich structure, facilitates the sewing and seam resistance. It can be a polyamide mesh or polyester and a nonwoven as well [10-14].

For the last layer of the car seat which is at the bottom is the polymer mesh fabric, highly used material is polyamide, but different polymers also can be used [15-17]. It is a high porous layer so that has high permeability. The biggest reason to use this layer is the PU foam, it smooth the back side of the PU so that the sewing and the covering of the car seat process is easier and faster.

\section{EXPERIMENTAL PART}

The seat cover of a car includes the following 3 layers, where: $X$ is top fabric layer which touches the person/driver, $Y$ is interlining layer (focus of research is on this layer), $Z$ is thin porous polyester mesh and $P$ is the thick PU form as cushion material (figure 3 ).

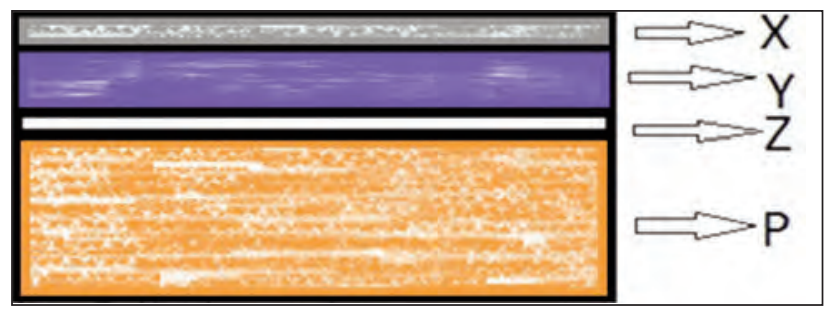

Fig. 3. Seat cover layers
The top layer's properties are shown in table 1 . The car seat covers are made of multiple layers and Layer $Y$ (figure 3) is responsible for the non-breathability of the car seat's cover material. Following different kinds of material are tested which are used as layer $Y$ in car seat cover.

\begin{tabular}{|c|c|}
\hline \multicolumn{2}{|c|}{ TESTING OF INTERLINING MATERIALS } \\
\hline $\begin{array}{c}\text { Top layer backing material } \\
\text { (layer } \text { Y) }\end{array}$ & $\begin{array}{c}\text { Thickness } \\
(\mathbf{m m})\end{array}$ \\
\hline 3D spacer fabric & 5 \\
\hline Non -woven felt & 5 \\
\hline Reticulated foam & 5 \\
\hline Classic PU-foam & 5 \\
\hline
\end{tabular}

Considering the comfort part, we need the top layer to be highly breathable, the moisture and air permeability of top layer are shown in figures 4 and 5 .

The air permeability is measured using the Air permeability tester (FX-3300) and SDLMO21S by using standard ISO9237 and the water vapour permeability is measured using the The sweating guarded hot plate, skin model (ISO 11092)

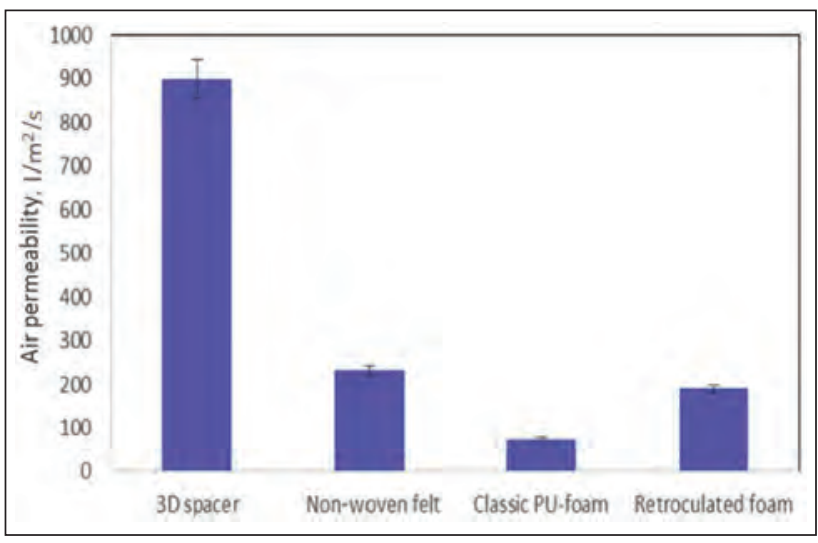

Fig. 4. Air permeability of top layers 


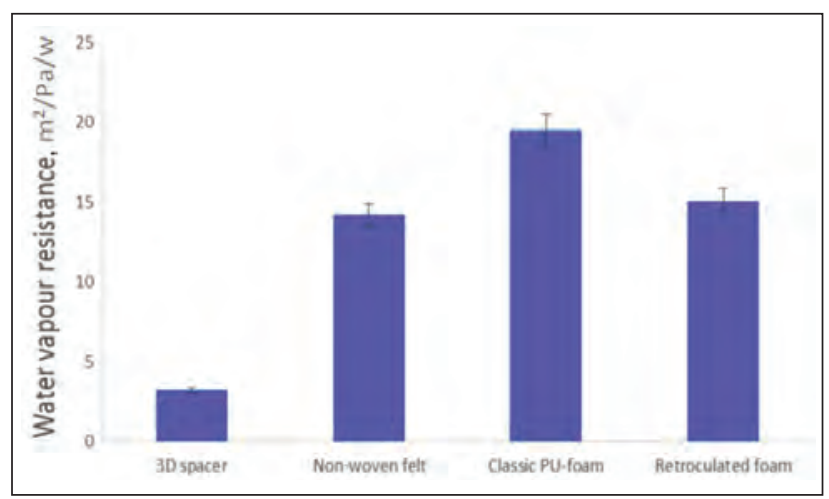

Fig. 5. Water vapour resistance of top layer

It is visible for figures 4 and 5 , that the 3D spacer fabric is highly permeable to air and has comparatively lower water vapour permeability.

\section{IMPERMEABLE PU-FOAM}

Lastly, it is clearly observed that the PU-foam is almost impermeable to air. The classic PU-foam and 3D spacer fabric are also examined under the X-ray tomography machine to see the internal structure of the material, and shows that the spacer fabric is almost open to movement of air whereas the PUfoam has a close pore structure and pores are not connected from one side to another face of the foam, which makes them impermeable to air.

The figures 6 and 7 clearly shows by X-RAY tomography that the PU-foam has closed pore structure which makes the material almost impermeable to the flow of air and moisture, where as in the case of the $3 \mathrm{D}$ space knitted fabric there is high porosity and the air can pass from one side to another side of the material which makes it highly permeable.

\section{MEASUREMENT OF MOISTURE PERMEABILITY UNDER LOAD}

The car seat cover materials are compressible, that means that their structure, porosity and thickness changes under load. A driver sitting on a car seat can totally change the defined performance of the car seat material.

A unique modification is made to the classical CUP METHOD for testing the moisture permeability with

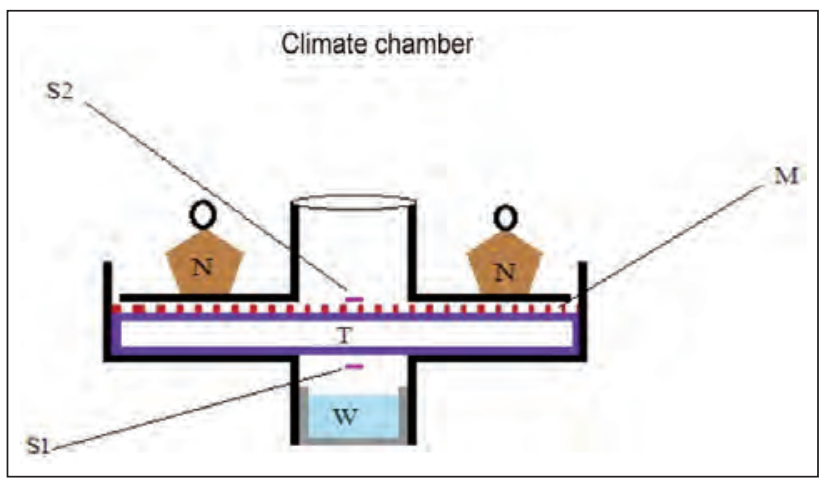

Fig. 8. Schematic diagram of the measuring device under load

and without load. A self-fabricated frame is used to hold the testing material with a constant pressure on it by using perforated metal mesh (figure 8). In figure $8, \mathrm{~W}$ is distilled water for moisture source, $\mathrm{T}$ is the car seat cover material, $\mathrm{N}$ is the load on the sample, $\mathrm{S} 1$ and S2 are the humidity sensors and $M$ is a porous sheet on the sample to apply even pressure.

Calculation of the water vapour transmission, and permeability is as follows.

$$
W V T=\frac{G}{t \cdot A}
$$

where $G$ is weight change (g), $t$ - time (h), $A$ - test area of $20 \mathrm{~cm}^{2}, W V T$ - rate of water vapour transmission $\left(\mathrm{g} / \mathrm{h} \cdot \mathrm{m}^{2}\right)$.

The experiment is performed in climate chamber with a controlled environment according to standard ASTM E 96-66. The sample properties are shown in table 2.

Table 2

\begin{tabular}{|c|c|}
\hline \multicolumn{2}{|c|}{ SAMPLE PROPERTIES } \\
\hline Sample & Thickness (mm) \\
\hline 3D spacer-1 & 10 \\
\hline 3D spacer-2 & 5 \\
\hline PU-foam 1 & 5 \\
\hline PU-foam 2 & 3 \\
\hline Retroculated foam & 5 \\
\hline Non-woven felt & 5 \\
\hline
\end{tabular}

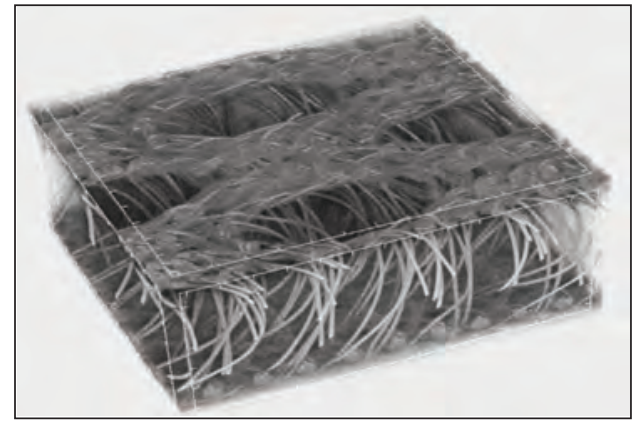

Fig. 6. X-ray tomography image of 3D spacer fabric

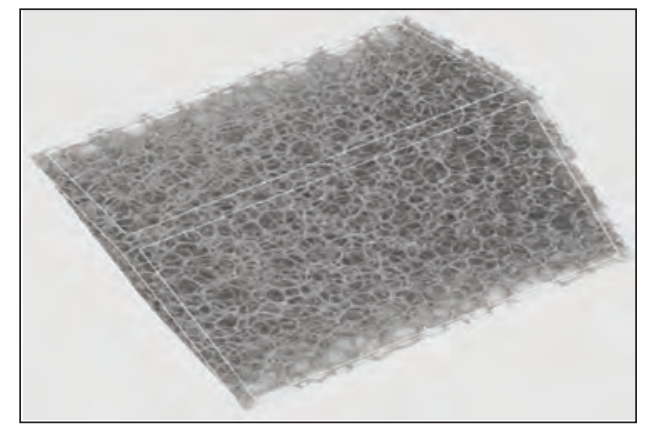

Fig. 7. X-ray tomography image of PU foam
To see the effect of the pressure on the moisture permeability the car seat materials are tested with and without loads. The moisture permeability of different car seat materials under two different pressure (5 and $10 \mathrm{kPa}$ ) and without pressure is 2020, vol. 71, no. 3 


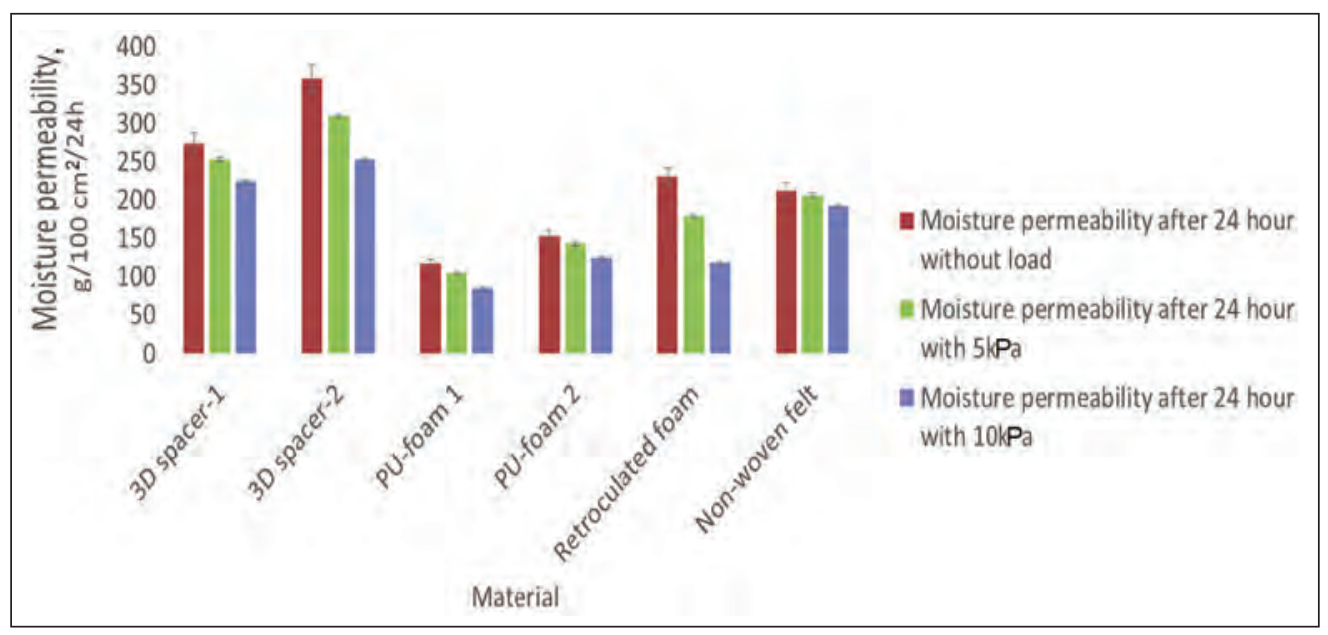

Fig. 9. Moisture permeability under load

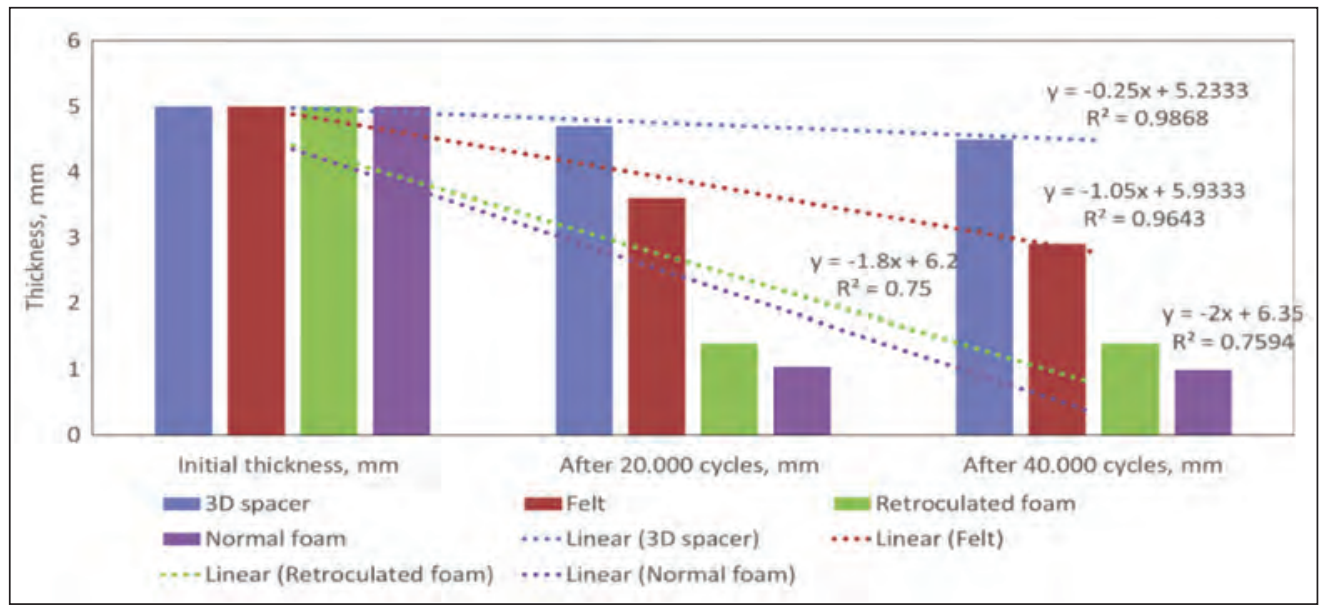

Fig. 10. Compressibility properties of the car seat cover

shown in figure 9. The experiment was performed 5 times for each sample and the error bars in the graph represent standard deviation.

The figure 9 shows that there is a significant effect of pressure on the permeability of the car seat material. This test method is unique and can show us experimentally how material behaves under load. It is visible that there is a significant decrease in moisture permeability when there is pressure on the car seat cover, which can be because of the closing of pores due to the pressure. All the materials are affected by the pressure but the permeability of $3 \mathrm{D}$ spacer is still higher as compared to any other material even after loading.

The effect of repeated loading of 40,000 cycles is shown in the figure 10 and 3D spacer shows better properties even after 40,000 cycles of repeated loading of $13 \mathrm{kPa}$.

Figure 10 clearly shows that the 3D spacer fabric has shown better compression properties and maintained its reasonable thickness after repeated loading of 40,000 times, followed by the nonwoven felt, reticulated foam and classic PU foam.

Whereas the classical PU-foam and reticulated foam loses its thickness in very early stages of the com- pression testing and then maintain a fixed compressed thickness. This shows that for the durability of car seats it's better to use 3D spacer or non-woven felt and considering the breathability, 3D spacer inhibit better performance than any other car seat material.

\section{CONCLUSION}

The research work shows an in-depth comparison of interlining car seat cover materials. Mostly the research focuses on the air and moisture permeability of different layers related to comfort. But in this research the performance of textile layers after static pressure and also compressibility properties of material after repeated loadings is tested. The results show that the $3 \mathrm{D}$ spacer fabric is the most permeable, followed by reticulated foam, non-woven web and classic PU foam, respectively. This research shows that 3D spacer fabrics are good alternatives for classic materials with better thermo-physiological comfort properties and better lifetime.

\section{ACKNOWLEDGEMENT}

This work was supported by the Ministry of Education, Youth and Sports in the Czech Republic under the "Inter 
Excellence - Action programme" within the framework of project "Micro-struCtural imaging as a Tool for modelinG fibrOus materiALS ( $\mu$-CT GOALS)" (registration number LTAUSA18135). This work was also supported by the Ministry of Education, Youth and Sports of the Czech
Republic and the European Union - European Structural and Investment Funds in the frames of Operational Programme Research, Development and Education - project Hybrid Materials for Hierarchical Structures $(\mathrm{HyHi}$, Reg. No. CZ.02.1.01/0.0/0.0/16_019/0000843).

\section{REFERENCES}

[1] Jerkovic, I., Pallares, J.M., Capdevila, X., Study of the Abrasion Resistance in the Upholstery of Automobile Seats, In: AUTEX Research Journal, 2010, 10, 14-20

[2] Fung, W., Hardcastle, M., Textiles in Automotive Engineering, Woodhead Publishing Ltd., Cambridge, England, 2001, ISBN: 1-58716-080-3

[3] Erth, H., Gulich Stfi, B., Three-dimensional textiles and nonwovens for polyurethane foam substitution in car seats, In: Textile advances in the automotive industry, Woodhead Publishing in Textiles, 2008, 79, 140-149, ISBN 978-184569-331-2

[4] Stegmaier, T., Mavely, J., Schweins, M., Arnim, V.V., Schmeer-Lioe, G., Schneider, P., Finckh, H., Planck, H., Woven and knitted fabrics used in automotive interiors, In: Textile advances in the automotive industry, Woodhead Publishing in Textiles, 2008, 79, 43-62, ISBN 978-1-84569-331-2

[5] Boussu, F., Cochrane, C., Lewandowski, M., Koncar-Ensait, V., Smart textiles in automotive interiors, In: Textile advances in the automotive industry, Woodhead Publishing in Textiles, 2008, 79, 172-197, ISBN 978-1-84569-331-2

[6] Parts for the Automotive industry, History of Car Seat Padding, Available at: http://www.euromoulders.org/ polyurethane-foam/history-of-car-seat-padding [Accessed March 31th 2017]

[7] Powell, N.B., Design of automotive interior textiles, In: Textile advances in the automotive industry, Woodhead Publishing in Textiles, 2008, 79, 113-139, ISBN 978-1-84569-331-2

[8] Ye, X., Fangueiro, R., Hu, H., Araújo, M., Application of warp knitted spacer fabrics in car seats, In: The Journal of The Textile Institute, 2007, 98, 337-344

[9] Powell, N.B., Design of automotive interior textiles, In: Textile advances in the automotive industry, Woodhead Publishing in Textiles, 2008, 79, 113-139, ISBN 978-1-84569-331-2

[10] Shim, E., Bonding Requirements in Coating and Laminating of Textiles, In: Joining Textiles: Principle and Applications, Woodhead Publishing, 2013, 110, 309-347, ISBN 9781845696276

[11] Normand, X., Recycling of automotive textiles, In: Textile advances in the automotive industry, Woodhead Publishing in Textiles, 2008, 79, 86-110, ISBN 978-1-84569-331-2

[12] Mazari, A., Bal, K., Havelka, A., Prediction of needle heating in an industrial sewing machine, In: Textile research Journal, 2016, 86, 3, 302-310

[13] Madsen, T.L., Thermal effects of ventilated car seats, In: International Journal of Industrial Ergonomics, 1994, 13, 253-258

[14] Snycerski, M., Frontczak-Wasiak, I., Influence of Furniture Covering Textiles on Moisture Transport in a Car Seat Upholstery Package, In: AUTEX Research Journal, 2002, 2, 3, 126-131

[15] Aniket, Gabhane, A., Waghmare, A.V., Design of Comfortable Advanced Ventilated Automotive Seat for Driver using CFD simulation, In: International Research Journal of Engineering and Technology, 2016, 3, 1979-1985

[16] Mangat, A.E., Hes, L., Bajzik, V., Mazari, A., Thermal Absorptivity Model of Knitted Rib Fabric and its Experimental Verification, In: Autex Research journal, 2018, 18, 1, 20-27

[17] Hänel, S.E., Dartman, T., Shishoo, R., Measuring methods for comfort rating of seats and beds, In: International Journal of Industrial Ergonomics, 1997, 20, 2, 163-172

Authors:

FUNDA BUYUK MAZARI ${ }^{1}$, ADNAN MAZARI ${ }^{1}$, ADNAN CIRKL $^{2}$, ANTONIN HAVELKA ${ }^{1}$

${ }^{1}$ Department of Clothing Technologies, Faculty of Textile Engineering, Technical University of Liberec, Liberec, Czech Republic

2Department of Applied Mechanics, Technical University of Liberec,

Liberec, Czech Republic

Corresponding author:

FUNDA BUYUK MAZARI

e-mail: fundabuyuk@hotmail.com 


\section{Evaluation of stain release based on image histogram analysis}

DOI: 10.35530/IT.071.03.1641

SHAO FEN-JUAN

YAN YULONG

XU PINGHUA

FAN WEICHAO

\section{ABSTRACT - REZUMAT}

\section{Evaluation of stain release based on image histogram analysis}

In our daily life, subjective and objective method were used to evaluate the washing condition of the stain. But they have some disadvantages, such as subjectivity, special operation in laboratory, limited area, and so on. With the development of technology, the image analysis was widely used in industry. In this article, the pictures of stains before and after being washed were got through image acquisition system. And then histogram based on distance were draw and similarity of stain before and after was calculated. The similarity described the degree of washing. The higher the similarity, the more similar the image, the less stain was washed out. Two different results got from washing efficiency and image analysis were analyzed through SPSS software, the results showed that in less than 0.05 level, two groups of data had a significant correlation. This means that the image analysis could be used to evaluate the stain release well.

Keywords: stain release, washing, objective instrument, image analysis, correlation

\section{Evaluarea eficienței îndepărtării petelor pe baza analizei histogramei imaginii}

În viața de zi cu zi, se folosesc metode subiective și obiective pentru evaluarea eficienței îndepărtării petelor. Dar acestea prezintă unele dezavantaje, cum ar fi subiectivitatea, echipamente speciale de laborator, zona limitată etc. Odată cu dezvoltarea tehnologiei, analiza imaginii a fost utilizată pe scară largă în industrie. În acest articol, imaginile petelor înainte și după ce au fost spălate au fost obținute prin intermediul sistemului de achiziție de imagini. Ulterior, s-a obținut histograma bazată pe distanță și s-a calculat similitudinea petei înainte și după spălare. Similitudinea a descris gradul de spălare. Cu cât similitudinea este mai mare, cu atât imaginea este mai asemănătoare, iar pata mai puțin îndepărtată. Două rezultate diferite obținute prin eficiența spălării și analiza imaginii au fost studiate prin intermediul software-ului SPSS, rezultatele arătând că, la un nivel mai mic de 0,05, două grupuri de date au avut o corelație semnificativă. Aceasta înseamnă că analiza imaginii ar putea fi folosită pentru a evalua corespunzător eficiența îndepărtării petelor.

Cuvinte-cheie: îndepărtare petelor, spălare, instrument obiectiv, analiza imaginii, corelație

\section{INTRODUCTION}

Staining on fabric is a major concern to consumers. The evaluation of stain release has long been an important issue for researchers in the laundry and dry-cleaning industries and for others studying aspects of fabric-appearance retention [1-2].

Methods to evaluate stain release traditionally have involved visual assessment. The test used most often is AATCC Test Method 130 (Soil Release: Oily Stain Release Method) [3]. Due to the subjective nature of the rating method and the limited types of stains, the reliability and accuracy of the results are sometimes questioned [4-6]. More objective instrumental methods such as Datacolor, WSB-L and so on based on reflectance measurements and calculations are also widely used in industry. Other instrumental for example, microscopy, fluorometry, were also used in the test. All of them had some disadvantages, such as it must be tested in laboratory by special researcher and it had limited tested area [7-10]. Recently, image analysis has been applied into evaluating fabric performance, such as colour fastness, pilling, wrinkling and so on [11-17]. It could analyse the whole image of stain.

The image analysis based on the luminance histogram is used to analysis the image, but it lost many colour information. Then the colour histogram of an image is being studied. The colour histogram of an image represents the distribution of the composition of colours in the image. It shows different types of colours appeared and the number of pixels in each type of the colours appeared [18].

In this paper, standard stain cloths were being studied, such as sebum, carbon black, blood and so on. They were being washed under different washing conditions, then we analyzed the washing efficiency. We also analyzed the colour histogram of stain image which was got through Fuji film before and after being washed. The relationship between the results got by image analysis and objective instrument was discussed. 


\section{EXPERIMENTAL DETAILS}

\section{Experimental materials}

Five different kinds of stain cloth were used in our study, they were shown in table 1. Color Tester (7000A, EYE Macbeth) and Digieye Digital imaging quick rating system (d/8), England were used.

Table 1

\begin{tabular}{|c|c|c|}
\hline \multicolumn{3}{|c|}{ DIFFERENT KINDS OF STAINS CLOTH } \\
\hline No. & Stain cloth & Brand \\
\hline 106 & $\begin{array}{c}\text { Cotton soiled with IEC carbon } \\
\text { black/mineral oil }\end{array}$ & EMPA \\
\hline 111 & Cotton soiled with blood & EMPA \\
\hline 112 & Cotton soiled with cocoa & EMPA \\
\hline 114 & Cotton soiled with red wine & EMPA \\
\hline 118 & Cotton soiled with sebum/pigmen & EMPA \\
\hline
\end{tabular}

\section{Sample treatments}

The stain cloth were being washed in Front-loading Washing Machine (JW75-12SUJB, JiDe), and the washing conditions were shown in table 2. 20 groups were being discussed. During each washing, five kinds of stain $(6 \mathrm{~cm} \times 6 \mathrm{~cm})$ were sewed on the load cloth and being washed together. In order to reduce the error, five pieces of each stain cloth were placed.

Table 2

\begin{tabular}{|c|c|c|c|}
\hline \multicolumn{4}{|c|}{ DIFFERENT WASHING CONDITIONS } \\
\hline No. & $\begin{array}{c}\text { Hardness } \\
\text { of water }\end{array}$ & Load & $\begin{array}{c}\text { Dose } \\
\text { of detergent }\end{array}$ \\
\hline 1 & 50 & 1 & 20 \\
\hline 2 & 50 & 1 & 60 \\
\hline 3 & 50 & 3 & 40 \\
\hline 4 & 50 & 3 & 40 \\
\hline 5 & 50 & 5 & 20 \\
\hline 6 & 50 & 5 & 60 \\
\hline 7 & 200 & 1 & 40 \\
\hline 8 & 200 & 1 & 40 \\
\hline 9 & 200 & 3 & 20 \\
\hline 10 & 200 & 3 & 20 \\
\hline 11 & 200 & 3 & 60 \\
\hline 12 & 200 & 3 & 60 \\
\hline 13 & 200 & 5 & 40 \\
\hline 14 & 200 & 5 & 40 \\
\hline 15 & 350 & 1 & 20 \\
\hline 16 & 350 & 1 & 60 \\
\hline 17 & 350 & 3 & 40 \\
\hline 18 & 350 & 3 & 40 \\
\hline 19 & 350 & 5 & 20 \\
\hline 20 & 350 & 5 & 60 \\
\hline
\end{tabular}

\section{Washing efficiency}

Washing efficiency, a measure of the wash effect, is an important index to evaluate the quality of cleaning (equation 1). Y represented the Green primary stimulus of tristimulus values. $Y$ of the stain before and after was got through the Color Tester. And the washing efficiency was calculated as follows, the final result of washing efficiency is the average of all the result in the group.

$$
D_{r}=\frac{Y_{w}-Y_{s}}{Y_{O}-Y_{s}} \times 100
$$

In the equation, $D_{r}$ is Washing Efficiency, $Y_{w}-$ Postwash Green primary stimulus of stained fabric, $Y_{s}-$ Before-wash Green primary stimulus of stained fabric and $Y_{O}$ - Original Green primary stimulus of fabric.

\section{Image analysis}

Image acquisition was the first step of the machine vision system for the stain release evaluation. The stain cloth was photographed in a standard, black box [19]. There is a circular standard light inside the top of the box. The camera was put in the middle. In the box, there was a sample holder in the box. Then the samples were put on it to be photographed. After the images were got, they were cut into uniform size to be analyzed in the later discussion.

\section{Image processing}

The distinctive features of a stain are its colour and intensity. In order to get accurate information, the colour information was discussed. This was achieved by transforming the image from RGB plane to the I, a, b. And the colour histogram of stain image was studied via Matlab software. The average distance of each pot of the histogram was calculated. Through this, the similarity of two images before and after being washed was calculated.

\section{RESULTS AND DISCUSSION}

\section{Washing efficiency}

JMP is a common experimental design software, which is used to analysis the level of multiple factors experiment. In our study, we chose "automatic detergent on the optimization of experimental data" for analysis. As is shown in table 2, the hardness of water, dosage of detergent and the load were changed. After being washed, the washing efficiency of stains was got according to equation 1. On the surface of the stain, five small areas of both sides were tested, and the average were got. The results were shown in table 3 . The stains which were being washed under different washing conditions had different washing efficiencies. This was because those different stains had different performances, then the washing efficiencies of stains were different from each other. But for each stain, the washing efficiency changed between certain ranges. 
Table 3

WASHING EFFICIENCY OF DIFFERENT STAINS UNDER DIFFERENT WASHING CONDITIONS

\begin{tabular}{|c|c|c|c|c|c|}
\hline Group & $\begin{array}{c}\text { Sebum } \\
(\%)\end{array}$ & $\begin{array}{c}\text { Carbon } \\
\text { black } \\
(\%)\end{array}$ & $\begin{array}{c}\text { Blood } \\
(\%)\end{array}$ & $\begin{array}{c}\text { Cocoa } \\
(\%)\end{array}$ & $\begin{array}{c}\text { Red } \\
\text { wine } \\
(\%)\end{array}$ \\
\hline 1 & 29.04 & 15.32 & 54.02 & 22.58 & 29.53 \\
\hline 2 & 29.19 & 15.07 & 58.74 & 21.12 & 34.58 \\
\hline 3 & 26.78 & 12.69 & 55.00 & 15.16 & 30.44 \\
\hline 4 & 24.90 & 11.93 & 55.57 & 17.28 & 30.52 \\
\hline 5 & 17.40 & 8.73 & 48.71 & 12.32 & 26.82 \\
\hline 6 & 21.91 & 9.41 & 52.12 & 12.52 & 28.45 \\
\hline 7 & 28.27 & 13.54 & 49.16 & 18.87 & 26.43 \\
\hline 8 & 27.10 & 13.77 & 54.25 & 19.04 & 29.54 \\
\hline 9 & 22.50 & 10.12 & 45.61 & 16.11 & 22.00 \\
\hline 10 & 22.75 & 8.19 & 46.28 & 17.08 & 22.10 \\
\hline 11 & 24.59 & 11.01 & 51.01 & 13.56 & 25.51 \\
\hline 12 & 24.94 & 8.96 & 42.95 & 11.98 & 24.27 \\
\hline 13 & 17.21 & 7.15 & 43.60 & 10.43 & 23.45 \\
\hline 14 & 17.44 & 8.56 & 45.34 & 12.30 & 25.77 \\
\hline 15 & 26.21 & 14.05 & 43.98 & 19.81 & 23.34 \\
\hline 16 & 25.83 & 11.03 & 47.32 & 16.72 & 26.98 \\
\hline 17 & 23.01 & 10.14 & 41.75 & 15.07 & 24.68 \\
\hline 18 & 21.26 & 10.95 & 40.97 & 14.28 & 24.03 \\
\hline 19 & 15.54 & 7.05 & 37.54 & 9.89 & 20.23 \\
\hline 20 & 18.25 & 7.39 & 40.11 & 11.20 & 25.21 \\
\hline & & & & & \\
\hline
\end{tabular}

Image analysis

According to measurements mentioned above, the image of the stain cloth before and after being washed was got through standard image acquisition system, which was listed in experimental details. The pictures of five kinds of stains from left to right were shown in figures 1 and 2 . Figure 1 showed the five kinds of stain before being washed. Figure 2 showed the five kinds of stain after being washed. It could be seen from figures 1 and 2 that the colours of stains were changed before and after being washed.

Five pieces of each stain cloth were got, and each image was analyzed. Take one stain for example,

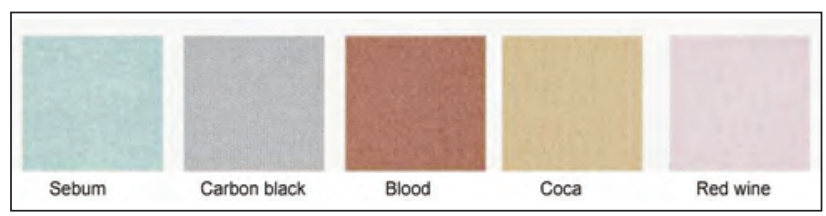

Fig. 1. Stain before being washed

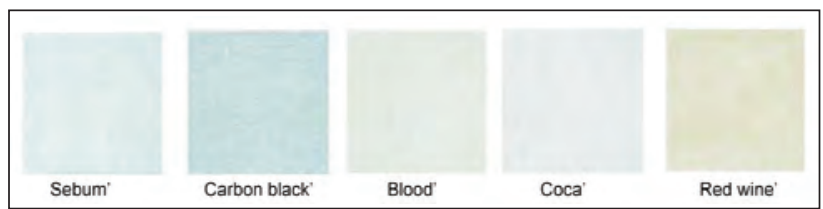

Fig. 2. Stain after being washed figure 3 showed the five pieces of blood being washed in Group 2. As is shown in figure 4, X-axis represented the value of $\mathrm{I}, \mathrm{a}, \mathrm{b}$, and $\mathrm{Y}$-axis represented the distribution at each position. We extracted the distribution of $\mathrm{I}, \mathrm{a}, \mathrm{b}$ of each image, calculated the distance of histogram of stains before (blue line) and after (red line) being washed. Then we averaged the results, the results were shown in table 4 . The value of similarity meant the degree of the similarity of two images. The higher the similarity, the more similar the image. This meant the stain was largely unwashed. The results of 20 groups were got in the same way and were shown in table 5 . It described the similarities of stains before and after being washed, which were got through the image analysis.

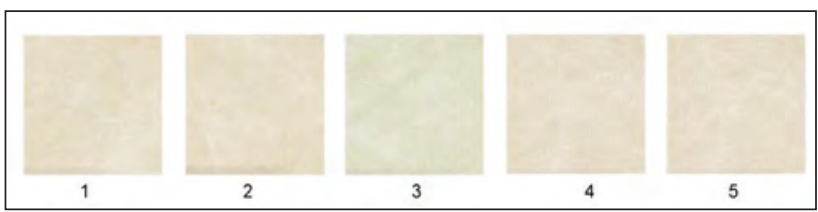

Fig. 3. Five pieces of blood of Group 2

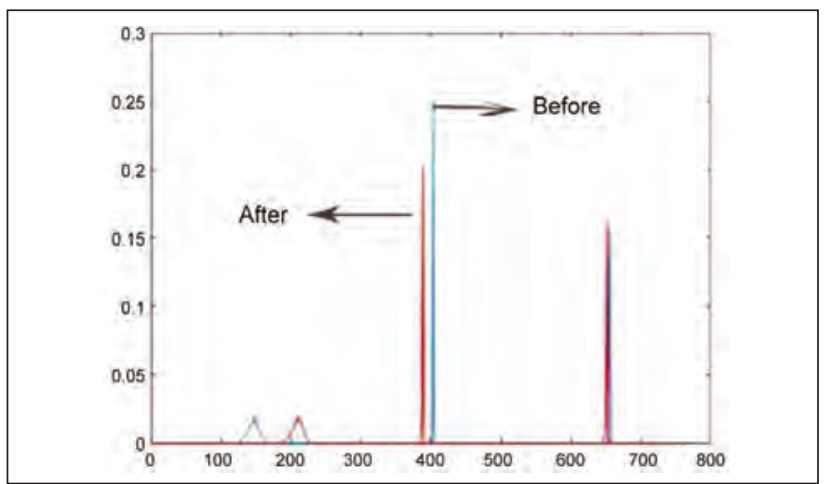

Fig. 4. Histogram distribution of blood before and after being washed

Table 4

THE SIMILARITY OF BLOOD BEFORE AND AFTER BEING WASHED

\begin{tabular}{|c|c|c|c|c|c|c|}
\hline \multirow{2}{*}{$\begin{array}{c}\text { Similarity } \\
\text { (\%) }\end{array}$} & $\mathbf{1}$ & $\mathbf{2}$ & $\mathbf{3}$ & $\mathbf{4}$ & $\mathbf{5}$ & Average \\
\cline { 2 - 7 } & 87.54 & 87.24 & 87.46 & 87.87 & 87.42 & 87.51 \\
\hline
\end{tabular}

It could be seen from table 5 that after being washed, the stain had a similarity with the original stain.

\section{Date analysis}

In order to evaluate the results of the image analysis, we use SPSS to discuss the relationship between the data got by objective instrument and image analysis. The results were shown in table 6 .

The higher the similarity, the more similar the image. This meant the stain was largely unwashed. On the contrary, the higher the washing efficiency, the more clean the stain cloth. So the Pearson correlation coefficient was negative. Table 6 showed the relationship between the data got by two different ways 
in the condition of $95 \%$ confidence interval. From table 6 , we could see that in less than 0.05 level, two groups of data had a significant correlation, the results varied from 0 to 0.030 . But the absolute value of Pearson correlation coefficient was not up to $85 \%$. It was because the image analyzed the whole image, meanwhile the certain area were taken for analysis in the test of objective instrument. In addition, the stain was uneven distributed. It could be seen in figure 3, there was white mask on the stain after being washed.

The cloths were got duty through the way of pad, there are stains on both sides of cloth. The stain was used in the test of detergent ad washing machines as standard cloth. Except this, we change the cloth, such as the material (polyester) of the cloth, the kinds of stain, and so on. We tested the cloth contained stains through painting stains on the cloth. The results of image analysis and objective instrument were coefficient.

\section{CONCLUSIONS}

The study presents a computer vision for evaluate the degree of stain release. Pictures of stains before and after being washed were got through image acquisition system and the histogram based on distance were draw and similarity of stain before and after was calculated. The similarity described the

Table 6

RELATIONSHIP BETWEEN THE DATA GOT BY TWO DIFFERENT WAYS

\begin{tabular}{|c|c|c|c|c|c|}
\hline & Sebum & $\begin{array}{c}\text { Carbon } \\
\text { black }\end{array}$ & Blood & Cocoa & $\begin{array}{c}\text { Red } \\
\text { wine }\end{array}$ \\
\hline $\begin{array}{c}\text { Pearson } \\
\text { correlation } \\
\text { coefficient }\end{array}$ & -0.511 & -0.712 & -0.598 & -0.671 & -0.498 \\
\hline Significance & 0.030 & 0 & 0.005 & 0.001 & 0.029 \\
\hline
\end{tabular}

degree of washing. The higher the similarity, the more similar the image, the less stain was washed out. The results showed that different results got from washing efficiency and image analysis had a significant correlation. The image analysis could be used to evaluate the stain release well.

\section{ACKNOWLEDFMENTS}

This work was supported by Found for daily work of postdoctoral of Shanghai (2017).

\section{REFERENCES}

[1] Kuo, C.F.J., Lee, C.J., Tsai, C.C., Using a netural network to identify fabric defects in dynamic cloth inspection, In: Textile Res. J., 2003, 73, 3, 238-244

[2] Xu, P.H., Ding, X.M., Wu, X.Y., Wang, R.W., Characterization and assessment of fabric smoothness appearance based on sparse coding, In: Textile Res. J., 2018, 88, 4, 367-378

[3] IEC 60456-2010, Clothes washing machines for household use - Methods for measuring the performance, International standard

[4] Xu, B., Reed, J.A., Instrumental evaluations of stains release in fabric, In: J. Textile Inst., 1996, 87, 1, 203-211

[5] Gururajan, A., Hequent, F., Sari-Sarraf, E.H., Objective evaluation of soil release in fabric, In: Textile Res. J., 2008, $78,9,782-79$

[6] Shen, J., Liu, J., Gao, W., Evalaution of satin release rating based on image analysis, In: Textile Res. J., 2013, 34, 3, 50-54

[7] Mao, C., Gururajan, A., Sari-Sarraf, E.H., Machine vision scheme for stain-release evaluation using Gabor filters with optimized coefficients, In: Mach. Vision Appl., 2012, 23, 2, 349-361

[8] Kuo, C.F.J., Su, T.L., Gray relational analysis of recognizing fabric defects, In: Textile Res. J., 2003, 73, 5, 461-465

[9] Kuo, C.F.J., Lee, C.-J., A back-propagation neural network for recognizing fabric defects, In: Textile Res. J., 2003, $73,2,147-151$ 
[10] Celik, H.I., Dulger, L.U., Topabekiroglu, M., Development of a machine vision system: real-time fabric defect detection and classification with neural networks, In: J. Textile Inst., 2014, 105, 6, 575-585

[11] Bugao, X., Evaluation of color alterations on fabrics by image analysis, In: Aatcc Review, 2009, 37-42

[12] Goncalves, P.L.S., Furtao, H.A.M., Morato, J.P.F.R., Goncalves, M.A.C., Automatic fabric inspection by machinevision, applying simple algorithms, In: Machine vision application in industrial inspection, 2002, 4664, 198-206

[13] Hu, Y., Long, Z., AIRegib, G., A high-speed, real-time vision system for texture tracking and tracking and thread counting, In: IEEE SIGNAL processing letters, 2018, 25, 6, 758-762

[14] Deng, D., Wang, R., Wu, H., Learning deeping similarity models with focus ranking for fabric image retrievals, In: Image Vision Comput., 2018, 70, 11-20

[15] Li, C., Gao, G., Liu, Z., Fabric defect detection based on biological vision modeling, In: IEEE ACCESS, 2018, 6 , 27659-27670

[16] Koya, Y., Yue, B., Nakata, T., Araki, M., Vision inspection automation for yarn breakage of warp knitted fabric, In: Transactions of the society of instrument and control engineers, 2017, 53, 2, 134-143

[17] Hill, M., Kamalakannan, S., Gururajan, A., Dimensional change measurement and stain segmentation in printed fabrics, In: Textile Res. J., 2011, 81, 16, 1655-1672

[18] Ghosh, A., Guha, T., Bhar, R.B., Pattern classification of fabric defects using supports vector machines, In: International Journal of clothing science and technology, 2011, 23, 2-3, 142-151

[19] Xuemei, D., Hong, L., Pinghua, X., Xiongying, W., Objective evaluation methods based on the visual perception of washing device about detergency, 2016109125764

Authors:

SHAO FEN-JUAN ${ }^{1}$, XU PINGHUA ${ }^{2}$, FAN WEICHAO ${ }^{1}$, YAN YULONG $^{3}$, DING XUEMEI ${ }^{1,2}$, WU XIONGYING ${ }^{1,3}$

${ }^{1}$ College of Fashion and Design, Donghua University, 200051, Shanghai, China

${ }^{2}$ Key Laboratory of Clothing Design \& Technology, Donghua University, Ministry of Education, 200051, Shanghai, China

${ }^{3}$ Shanghai customs district, 200002, Shanghai, China

Corresponding author:

DING XUEMEI

e-mail: fddingxm@163.com 


\title{
Accounting and evaluation of chemical footprint of cotton woven fabrics
}

\author{
DOI: 10.35530/IT.071.03.1678
}

JIA-HONG QIAN

\section{ABSTRACT - REZUMAT}

\section{Accounting and evaluation of chemical footprint of cotton woven fabrics}

The major environmental impacts of textile products tend to arise from emissions of toxic substances in the production phase of the life cycle. The theory of chemical footprint (ChF) can be used to study the environmental impact of textile products and leads a new way to quantitatively assess impacts of toxic substances. In this paper, environmental impacts of $1 \mathrm{~kg}$ cotton woven fabric were assessed from yarn to finished fabric in terms of its contributions to the ecological system. The results showed that the total ChF in the calculation boundary associated with ecotoxicity was approximately $41526.10 \mathrm{PAF} \cdot \mathrm{m}^{3} \cdot d$. The largest ChF for cotton woven fabric mainly came from weaving process, followed by cultivation and harvesting and fabric processing phases. Sizing agent and all kinds of base potentially created the large ecotoxicity and there are considerable differences in magnitude from other materials' ecotoxicity. It also revealed that the selection of auxiliaries was more important than that of dyestuffs. ChF does well in drawing more focus on the source of industry pollution and plays an important role in improving management efficiency in assessing and choosing chemicals.

Keywords: chemical footprint, environmental load, cotton woven fabrics, productive technologies

\section{Evidența și evaluarea amprentei chimice a țesăturilor din bumbac}

Impactul major asupra mediului al produselor textile apare din emisiile de substanțe toxice în faza de producție a ciclului de viață. Teoria amprentei chimice (ChF) poate fi utilizată pentru a studia impactul asupra mediului al produselor textile și conduce la o nouă modalitate de evaluare cantitativă a impactului substanțelor toxice. În această lucrare, impactul asupra mediului al țesăturii din bumbac de $1 \mathrm{~kg}$ a fost evaluat de la fire până la țesăturile finite, din punctul de vedere al contribuțiilor la sistemul ecologic. Rezultatele au arătat că ChF total în limita de calcul asociată cu ecotoxicitatea a fost de aproximativ de 41526,10 $\mathrm{PAF} \cdot \mathrm{m}^{3} \cdot d$. Cea mai mare valoare ChF pentru țesătura din bumbac a provenit în principal din procesul de țesere, urmat de cultivare și recoltare și fazele de prelucrare ale țesăturilor. Agentul de încleiere a creat o posibilă ecotoxicitate ridicată și există diferențe considerabile de ecotoxicitate față de alte materiale. De asemenea, s-a constatat că selecția substanțelor auxiliare a fost mai importantă decât cea a coloranților. ChF identifică sursa de poluare din industrie și deține un rol important în managementul eficient de evaluarea și selecție al substanțelor chimice.

Cuvinte-cheie: amprenta chimică, protecția mediului, țesături din bumbac, tehnologii de producție

\section{INTRODUCTION}

Chemicals play a crucial role in providing function for materials and products among other things. The textile industry, one of the world's largest industries, is an intense user of chemicals. Currently, millions of chemicals are consumed in the manufacturing of textiles products. A study showed that between 1.5 to $6.9 \mathrm{~kg}$ of chemicals are used per kg textiles, which means that the weight of chemicals used in the production process is larger than that of the finished garment [1]. Not only will chemical pollution influence economic development [2], but also they can reach environmental compartments and do damage to human health and ecological environment.

Commonly, chemicals tend to be released in the form of mixture. As a result, it is almost impossible to know the potential impact that all these chemical compounds and their mixtures might generate, unless a large amount of money, resources and time are spent [3].
The theory of chemical footprint (ChF) provides a new idea for environmental load assessment that recommends people to keep a watchful eye on the chemicals' toxicity in the production and makes it possible for civil society and companies to be the important subject in regulating pollution as a quantitative evaluation tool [4]. The idea of ChF was first introduced in a commercial report in 2011 [5] and has gained extensive interest since then. The ChF research is still in its early stages. In summary, the concepts of ChF can be grouped into three categories: toxic stress, environmental space or mass of chemicals and the first explanation is considered more reasonable in product level [1]. It means that it is a method characterized by the potential human toxicity and ecological toxicity of chemical pollutants discharged by human activities. ChF tends to be estimated by using the existing mature models in the field of ecotoxicology and USEtox model is the consensus model resulting from extensive comparison of existing Life Cycle Assessment (LCA) methods for 
toxicity impact assessment by an international team of LCA experts [6]. For example, Sala and Goralczyk [7] used the concept of comparative toxic unit for freshwater ecosystem in that model to characterize the ecological toxic effects of chemicals in European Union. In 2014, combining with the weight of chemical emission, Bjørn et al. [8] gave the chemical footprint calculation formula and calculated the region scale ChF. Roos et al. [9] firstly introduced USEtox model into textile and apparel industry, and concluded that the unbleached garments were not better than bleached ones when taking the service life into account.

Cotton textiles are one of the most important products for good performance, such as durability, easy washability and comfort. According to statistics, the global cotton fiber output in 2016 was 23.21 million tons, accounting for nearly a quarter of the total fiber output [10]. In the production of cotton textiles, wet treatment, including pre-treatment, mercerizing, dyeing and finishing, is considered as an infamous source of the environmental load, in which abundant chemicals, water resources and energy will be consumed [11]. Attention has increasingly been paid to the environmental problems in the production of cotton textiles, and climate change and water use are well-developed impact categories in assessing environmental load [12]. Both semi-finished products and finished products like cotton woven bags [13], T-shirts [14], fabrics [15-16], yarns [17] and fibres [18] have been studied, aiming at evaluating the greenhouse gases, water shortage or other categories in their life cycle. However, there is negligible literature published on the impacts of toxicity on the environment that brought about by chemical use in cotton textile production based on chemical footprint theory, though the effects of chemicals are more profound and lasting.

Therefore, this study is aimed at assessing and comparing the potential ecotoxicity impacts of different processes in cotton woven fabric production by accounting $\mathrm{ChF}$, and raising public attention on the use and election of textile chemicals. The main part of the article includes the following aspects: the first part is methodology and data, the second is results and discussion, and the last is conclusion.

\section{METHODOLOGY AND DATA}

\section{Method}

USEtox is generally recognized as the most advanced model currently available for comparative assessment of chemicals and their toxic effects on humans and freshwater ecosystems [19]. The paper mainly aimed at the impacts on aquatic ecosystem, therefore the impact score in the model is described as followed:

$$
I S=\sum_{i, j} Q_{i, j} \times C F_{i, j}
$$

where IS is the impact score for ecological toxicity $\left(\mathrm{PAF} \cdot \mathrm{m}^{3} \cdot \mathrm{d}\right), C F_{i, j}$ - the characterisation of substance $i$ released to compartment $j\left(\mathrm{PAF} \cdot \mathrm{m}^{3} \cdot \mathrm{d} / \mathrm{kg}\right)$ and $Q_{i, j}$ the quality of emission $i(\mathrm{~kg})$. The equation has summed over all chemicals and emission compartments in the emissions inventory [8]. The CFs of chemicals are computed as the result of the product of three factors: a fate factor (FF), an exposure factor $(\mathrm{XF})$ and an effect factor (EF). The fate factor represents the residence time of a chemical in a specific compartment, which is directly connected with the degradation capabilities. The effect factor reflects the change in the PAF of species due to change in ecotoxicant concentration and the exposure factor for ecotoxicity is the fraction of a chemical dissolved in a medium.

To calculate the ChF of an emission inventory, equation 2 was put forward by equation 1 . In equation 2 , 290 is dimensionless and is an Correction factor to balance the result of impact scores and ChFs.

$$
C h F=290 \times I S
$$

\section{Calculation boundary}

The first step in accounting chemical footprint is to determine the calculation boundary. The textile production chain is often described as long and complex and includes several production steps, like yarn spinning, weaving, dyeing, sewing and so on. In this paper, the calculation boundary of chemical footprint was from yarn to fabric. Figure 1 briefly shows the industrial production chain of cotton woven fabric in this paper in which processes potentially create more pollution, including weaving and dyeing \& finishing. The weaving was conducted in a weaving factory, while dyeing \& finishing was conducted in a printing and dyeing factory. All the aspects that should be taken into account were both input and output dyes and auxiliaries in these processes. The focus has been on the textile production processes and indirect emissions occurring in the textile life cycle, such as pollutants from fuel combustion and the production of chemicals, were not taken into account.

\section{Data}

In the calculation boundary, chemical species include dyestuffs, bases, sizing agents, desizing agents, stabilizers, bleach, softeners and so on. The main data in the life cycle inventory, like chemical input and output and chemical compositions were provided by two enterprises. The two enterprises that are above designated size have built a relation of upstream and downstream. This article has represented the actual situation of pollution production. Therefore, the data about chemical emissions was all measured before wastewater treatment systems. Characterisation factors were mainly accounted in USEtox model. The left were in Cosmede database and some published literature [20-21]. After the conversion of annual output and consumption data, the functional unit was defined as $1 \mathrm{~kg}$ of cotton woven fabric. The basic information of the fabric is shown in the table 1. 


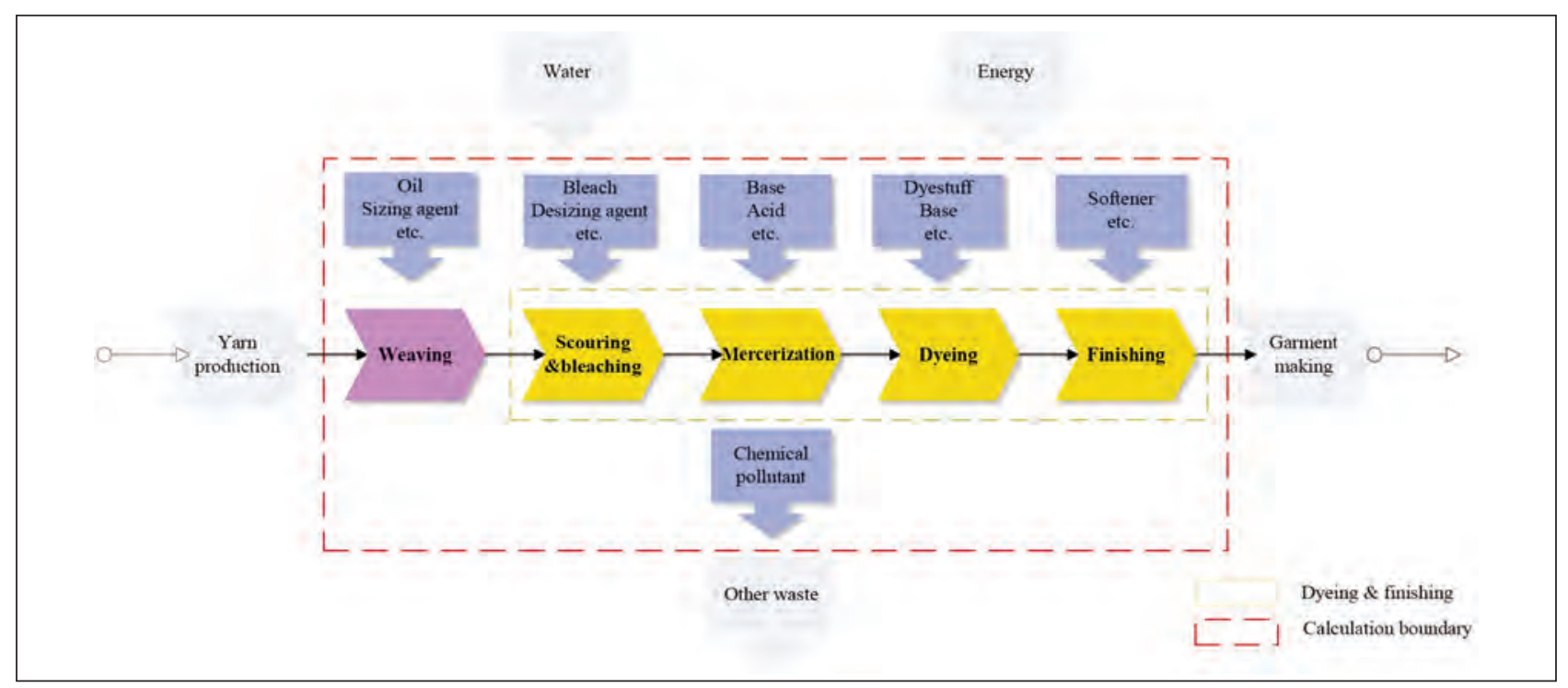

Fig. 1. The calculation boundary of chemical footprint of cotton woven fabric

Table 1

\begin{tabular}{|c|c|}
\hline \multicolumn{2}{|c|}{ FABRIC BASIC INFORMATION } \\
\hline Property & Value \\
\hline Raw material & $100 \%$ cotton \\
\hline Texture & Tabby weaving \\
\hline Weight $\left(\mathrm{g} / \mathrm{m}^{2}\right)$ & 158.5 \\
\hline Warp density $($ yarn $/ \mathrm{cm})$ & 100.4 \\
\hline Weft density $($ yarn $/ \mathrm{cm})$ & 101.6 \\
\hline Thickness $(\mathrm{mm})$ & 0.24 \\
\hline
\end{tabular}

\section{RESULTS AND DISCUSSION}

Figure 2 shows the potential contribution to freshwater ecotoxicity of per $\mathrm{kg}$ cotton woven fabric. According to the results, the total chemical footprint associated with ecotoxicity in the calculation is approximately $41526.10 \mathrm{PAF} \cdot \mathrm{m}^{3} \cdot \mathrm{d}$. The $\mathrm{ChFs}$ of the production processes are obviously different from each other. Weaving process stands for the largest contribution to freshwater ecotoxicity impact and takes more than two thirds of the referred fabric's ChF, then followed by Scouring \& bleaching, Mercerization. Surprisingly, the dyeing process is proved to contribute the least to ecotoxicity and the $\mathrm{ChF}$ was below $10 \mathrm{PAF} \cdot \mathrm{m}^{3} \cdot \mathrm{d}$.

In weaving, yarn especially the warp yarn is required with high strength, on account of subjecting to greater tension. Therefore, before weaving the yarn are sized to lower friction and increase tensile properties during weaving. To improve the sizing performance, the sizing percentage should be limited in a certain range, which means most of the sizing agents will discharge into the environment with waste water [22] and it was the most significant reason why the process contributed a lot to ChF. The one-step pretreatment in wet treatment in this paper is regarded as higher efficient and shorter process. However, due to reduce the impurities of cotton fabrics to low levels, it is necessary to increase the amount of chemical agent, especially for fabrics with high sizing percentage, which increase the burden of wastewater treatment [23]. More eco-friendly chemicals are used in this process, like alpha-amylase, hydrogen peroxide and so on. Mercetization is to improve the luster of cotton woven fabric after alkali treatment. Aimed at lowering the $\mathrm{pH}$ of the fabrics, the residual base on the fabric is neutralized to generate salts. Contrary to expectation, the ChF of dyeing process is not large. It may be assumed that the use and discharge of chemicals are concentrated in the early stage and it costs more time and water to wash in order to achieve the inspection requirements such as $\mathrm{pH}$ value and colour fastness.

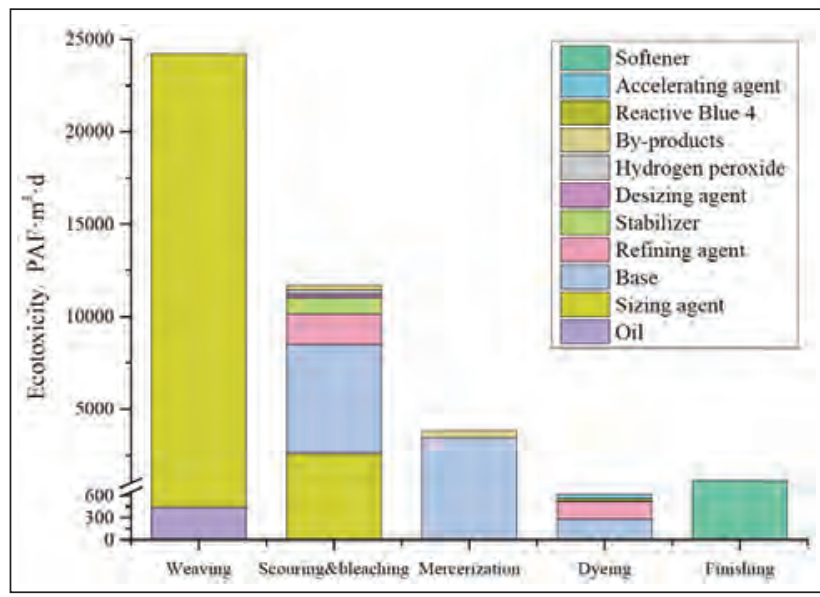

Fig. 2. Comparison of ecotoxicity of process chain segment

Figure 3 shows the process of substances transforming from textile chemicals to chemical pollutants in the calculation boundary. The conversion process of chemical with a larger contribution to the results is represented by a thicker connecting line between the input and output, which we should draw more 
attention to. It is shown that triphenyl phosphate potentially creates the largest ecotoxicity, about 26282.49 $\mathrm{PAF} \cdot \mathrm{m}^{3} \cdot \mathrm{d}$ among all the pollutants, which was generated by sizing agent in the production. Besides, base used in the production also accounts for a large proportion of the total ecotoxicity footprint, nearly $24 \%$. On the other side, pollutants like 1,2propanediol, acetaldehyde and acetaldehyde have little influence on ecotoxicity, with more than 2 orders of magnitude less than other pollutants. Among all the textile chemicals, the sizing agent obviously tends to create a considerable influence on the results.

The size selected in this paper was starch, which had characteristics of cheap price and little pollution to the environment. In order to improve the stiff and brittle performance of starch size film and increase the starch adhesion for cotton, a small amount of plasticizer will be added [24], like triphenyl phosphate in this case. As a persistent organic pollutant, research indicates that a certain dose of triphenyl phosphate has an ecological toxic effect on aquatic organisms [25]. Thus, the CF of this substance is much bigger than others in this paper. Refining agents consist of high-quality environmentally friendly formula, including dodecyl sulfonate, sodium salt lauryl phosphate and primary alcohol ethoxylate. Primary alcohol ethoxylate is the substitute for alkylphenol ethoxylates, which are potential hazardous to environment because of its toxicity and poor biodegradability [26]. The usage of the agent was the largest among all the organic chemicals and a lot of residual agent and the by-products will spew into the water. The impact of the refining agent can by no means be overlooked.
Hydrogen peroxide bleaching agent is proved greener and more environmentally friendly as its degradation products, water and oxygen are harmless [27]. Because darker shades of blue would be added, the amount of bleach is relatively small. But in the scouring \& bleaching, stabilizers are used to control the decomposition rate of hydrogen peroxide. According to the semi-lethal concentration, the stabilizer, silicic acid, sodium is a low-toxic chemical. However, in order to fully improve the utilization rate of hydrogen peroxide, the usage of silicic acid, sodium should be twice as much as that of hydrogen peroxide in beaching. It is the major reason why silicic acid, sodium have great effect on ChF.

In this paper, we focus on the chemical consumption and eco-environmental stress caused by chemical pollution along industrial production chain from yarn to fabric. The weaving process cannot be ignored or underestimated. Large quantity of sizing agent will be directly converted into wastewater if the factory does not carry out recycling. It means that the factory should pay more attention to recycling of size and the recycling equipment. Nowadays, the development of ultrafiltration technology makes it possible for the recovery rate of size to reach $85 \%$ in production. Also, citrate and epoxy vegetable oil plasticizers are kinds of sustainable development of environmental protection plasticizers in industrial production to further reduce the pollution [28]. Minimizing the pollution brought about by sizing agent is highly possible. The process scouring \& bleaching plays an important role in dyeing and finishing. It is claimed that around $45 \%$ quality problems of fabrics are caused by improper pre-treatment [29]. Enzymes tend to be utilized in the

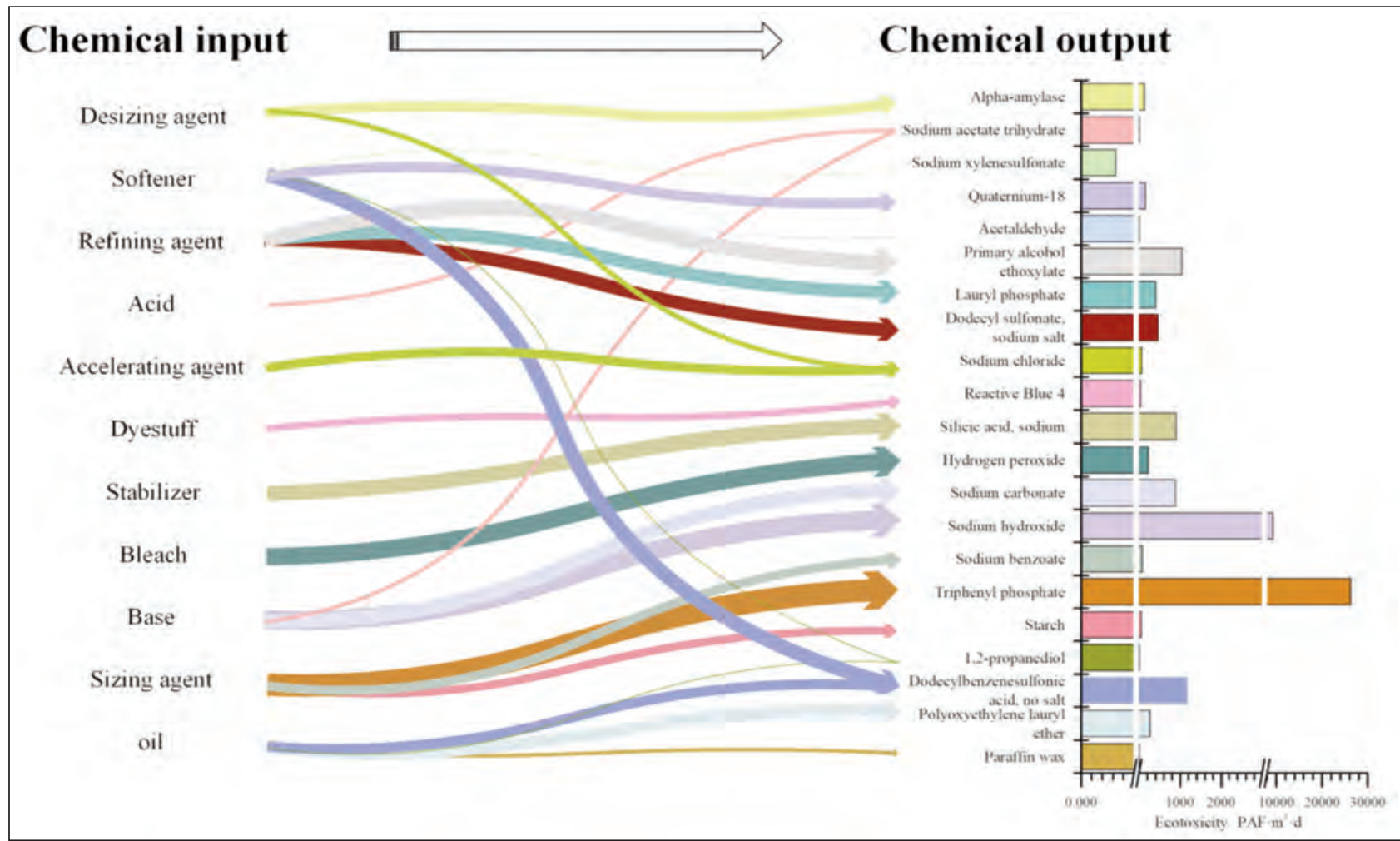

Fig. 3. Sources and ecotoxicity of chemical pollutants 
pre-treatment process of cotton fabrics, which generates minimum by-products and minimizes the risks to humans, wildlife and the environment [30-31]. In mercerizing process, part of the enterprises choose to directly discharge mercerizing wastewater before treating, which results in not only a waste of alkali liquor but also an enormous threat to the environment. Through a reasonable alkali recovery project, dilute alkali can be used in desizing, scouring, mercerizing and other processes [31]. Besides, Liquid ammonia tend to be used as an alternative to sodium hydroxide in mercerization [32-33].

\section{CONCLUSIONS}

The use and emission of toxic chemicals from cotton woven fabric production are an important aspect to include in the impacts on environmental load studies of cotton woven fabrics. In order to mitigate the pollution, wastewater treatment techniques, like physical and chemical techniques, biotechnology and membrane separation technology will be most commonly adopted. However, the treatments just succeed in transferring chemical pollutants to other agents, but essentially fail to put an end to pollution. ChF is a way to help tackle the pollution problems at its source in chemical management.

In this paper, the ecotoxicity of $1 \mathrm{~kg}$ cotton woven fabric was assessed based on ChF methodology. It was shown that the total ecotoxicity was approximately 41526.10 PAF $\cdot \mathrm{m}^{3} \cdot \mathrm{d}$. and weaving was the most typical high toxicity technology. Generally, this might be one of the typical features of cotton woven fabrics. Among all the materials, triphenyl phosphate had the biggest impact on ecotoxicity of ChF due to its persisting pollution and high toxicity to ecosystem. To relieve the environmental load caused by alkaline substances, amylases are recommended in several processes, like desizing. With the prohibiting of high toxicity azo dyestuffs, more environmentally friendly dyestuffs are used as substitutes. Consequently it seems that the selection of auxiliaries is more important than the selection of dyestuffs, which is contrary to the common view that heavy focus should be put on how to choose dyestuffs.

As a quantitative assessment tool, ChF allows for identification of the technologies, pollution sources and pollutants, which can help companies recognize and prioritize opportunities for improvement to save cost and materials. Besides, ChF methodology also provides a new way of thinking for the development of future industrial emission standards in a more reasonable way of considering the toxic effects of pollutants.

Currently, there are still many challenges to overcome when it comes to the sustainable use of chemicals in the textile industry. The secret formula is one of them and it means more requirements will be set to chemical manufacturers. In future research, efforts are needed to be done to enrich the database and develop a model in order to make the evaluation process more systematized and efficient.

\section{ACKNOWLEDGMENTS}

The paper was supported by the National Key R\&D Program Subsidized Projects (2018YFF0215703), Zhejiang Provincial Natural Science Foundation of China (LY20G030001), the Young Researchers Foundation of Zhejiang Provincial Key Laboratory of Fiber Materials and Production Technology, Zhejiang Sci-Tech University (Project No. 2016QN06) and the Natural Science Foundation of China (Grant No. 61702460). The authors are also thankful to Sandra Roos, the researcher of Swerea IVF, for the guidance about how to select the CF of a specific substance.

\section{REFERENCES}

[1] Tian, Z., Wang, L., Li, Y., Calculation and assessment of chemical footprint of textiles and apparel, In: Silk, 2018, 56, 1, 33-37

[2] Barbi, F., Ferreira, L.C., Guo, S., Climate change challenges and China's response: mitigation and governance, In: Journal of Chinese Governance, 2016, 1, 2, 324-339

[3] Ortiz de García, S., García-Encina, P.A., Irusta-Mata, R., The potential ecotoxicological impact of pharmaceutical and personal care products on humans and freshwater, based on USEtoxTM characterization factors. a Spanish case study of toxicity impact scores, In: Science of the Total Environment, 2017, 609, 429-445

[4] Tan, Y., Fang, K., Environmental governance in China, In: Journal of Chinese Governance, 2016, 1, 1, 191-194

[5] Du, C., Wang, Z., Chen, J., Qian, X., Li, X., Xie, H., Cai, X., Chemical Footprint: Concepts, Research Progress and Challenges, In: Asian Journal of Ecotoxicolog, 2018, 11, 2, 18-26

[6] Rosenbaum, R.K., Huijbregts, M.J.A., Henderson, A.D., Margni, M., McKone, T.E., Meent, D., Hauschild, M.Z., Shaked, S., Li, D.S., Gold, L.S., Jolliet, O., USEtox human exposure and toxicity factors for comparative assessment of toxic emissions in life cycle analysis: sensitivity to key chemical properties, In: The International Journal of Life Cycle Assessment, 2011, 16, 8, 710-727

[7] Sala, S., Goralczyk, M., Chemical footprint: A methodological framework for bridging life cycle assessment and planetary boundaries for chemical pollution, In: Integrated Environmental Assessment and Management, 2013, 9, 4, 623-632

[8] Bjørn, A., Diamond, M., Birkved, M., Hauschild, M.Z., Chemical footprint method for improved communication of freshwater ecotoxicity impacts in the context of ecological limits, In: Environmental Science \& Technology, 2014, 48, 22, 13253-13262

[9] Roos, S., Posner, S., Jönsson, G., Peters, G.M., Is Unbleached Cotton Better Than Bleached? Exploring the Limits of Life-Cycle Assessment in the Textile Sector, In: Clothing and Textiles Research Journal, 2015, 33, 4, 231-247

[10] Wang, Y., Global fiber production: Slowdown of growth to only 1.7\%, In: Melliand China, 2018, 46, 3, 4-12 
[11] Hasanbeigi, A., Price, L., A technical review of emerging technologies for energy and water efficiency and pollution reduction in the textile industry, In: Journal of Cleaner Production, 2015, 95, 30-44

[12] Hellweg, S., Milà i Canals, L., Emerging approaches, challenges and opportunities in life cycle assessment, In: Science, 2014, 344, 6188, 1109

[13] Muthu, S.S., Yi, L., Hu, J., Mok, P., Lin, M., Modelling and quantification of Eco-functional Index: The concept and applications of eco-functional assessment, In: Ecological Indicators, 2013, 26, 33-43

[14] Gondran, N., The ecological footprint as a follow-up tool for an administration: Application for the Vanoise National Park, In: Ecological Indicators, 2012, 16, 157-166

[15] Wang, L., Wu, X., Ding, X., Wang, L., Yu, J., Case study on industrial carbon footprint and industrial water footprint of cotton knits, In: China Dyeing \& Finishing, 2012, 38, 2, 43-46

[16] Yan, Y., Jia, J., Wang, L., Du, C., Liu, X., Fu, X., Liu, X., Wu, G., The industrial water footprint of several typical cotton textiles in China, In: Acta Ecologica Sinica, 2014, 34, 23, 7119-7126

[17] Li, X., Xu, W., Zhu, J., Yang, Y., Calculation method of cotton carded yarn carbon footprint, In: Cotton Textile Technology, 2014, 42, 9, 19-23

[18] Wang, Z., Chen, J., Zhang, L., Chen, F., Sun, H., Liu, L., Song, W., Li, C., Li, Y., Carbon footprint analysis of cotton production in Hebei Province, In: Journal of Cotton Science, 2016, 28, 6, 594-600

[19] Hauschild, M.Z., Huijbregts, M., Jolliet, O., Macleod, M., Margni, M., van De Meent, D., Rosenbaum, R.K., Mckone, T.E., Building a model based on scientific consensus for life cycle impact assessment of chemicals: the search for harmony and parsimony, In: Environmental Science \& Technology, 2008, 42, 7032-7037

[20] Roos, S., Holmquist, H., Jönsson, C., Arvidsson, R., USEtox characterisation factors for textile chemicals based on a transparent data source selection strategy, In: The International Journal of Life Cycle Assessment, 2018, 23, 4, 890-903

[21] Roos, S., Peter, G.M., Three methods for strategic product toxicity assessment - the case of the cotton T-shirt, In: The International Journal of Life Cycle Assessment, 2013, 20, 7, 903-912

[22] Guo, Q., Cui, X., Control Measures of Stabilizing Sizing Percentage, In: Cotton Textile Technology, 2017, 45, 7, 60-63

[23] Wu, J., High Efficient and Short Process of Pre-treatment Process of Cotton and T/C Fabric, In: China Textile Leader, 2016, 4, 36-39

[24] Zhou, D., Shen, Y., Qian, X., Influence of plasticizer on starch size performance, In: Progress in Textile Science \& Technology, 2012, 1, 17-18, 92

[25] Luo, Y., Liu, N., Xu, J., Hu, X., Xu, Y., Jin, X., A tiered ecological risk assessment of triphenyl phosphate in Chinese surface waters, In: Asian Journal of Ecotoxicolog, 2018, 13, 5, 87-96

[26] Chen, R., Prohibition and substitution of APEO, In: China Dyeing \& Finishing, 2016, 32, 12, 45-49

[27] Sujata, S., Raja, A.S.M., Arputharaj, A., Challenges in Sustainable Wet Processing of Textiles. Textiles and Clothing Sustainability, Springer Singapore, 2017, 46-47

[28] Chen, R., Development of phthalate and environmental friendly plasticizer substitute, In: Textile Auxiliaries, 2011, $28,12,1-8$

[29] Liu, J., New energy conservation and emission reduction technologies in dyeing and finishing, In: China textile \& apparel press, Beijing, 2015, 10-12

[30] Choudhury, AK.R., Sustainable textile wet processing: applications of enzymes. Roadmap to Sustainable Textiles and Clothing, Springer Singapore, 2014, 1-36

[31] Buschle-Diller, G., Yang, X.D., Yamamoto, R., Enzymatic bleaching of cotton fabric with glucose oxidase, In: Textile Research Journal, 2001, 71, 5, 388-394

[32] Wang, J., Yu, C., Jiang, S., Yu, W., Application of recycling of dilute alkali from mercerizing, In: Textile Dyeing and Finishing Journal, 2013, 35, 1, 47-50

[33] Arputharaj, A., Raja, A.S.M., Saxena, S., Developments in Sustainable Chemical Processing of Textiles. Green Fashion, Springer Singapore, 2016, 224

Authors:

JIA-HONG QIAN ${ }^{1,3}$, YU-YING QIU ${ }^{2}$, YI-DUO YANG ${ }^{1,3}$, YI LI $^{4}$, PING-HUA XU1,3, LAI-LI WANG 1,3,4

1Zhejiang Provincial Research Center of Clothing Engineering Technology, Hangzhou, 310018, Zhejiang, China

${ }^{2}$ College of Design, Jiaxing University, Jiaxing, 314001, Zhejiang, China

${ }^{3}$ Silk and Fashion Culture Research Center of Zhejiang Province, Sci-Tech University, Hangzhou, 310018, Zhejiang, China

${ }^{4}$ Zhejiang Ecological Civilization Research Center, Hangzhou, 310018, Zhejiang, China e-mail: 201720401008@mails.zstu.edu.cn; skyqyy@163.com; 2017328420054@mails.zstu.edu.cn; liyi2009@zstu.edu.cn; shutexph@163.com

Corresponding author:

LAI-LI WANG

e-mail: wangll@zstu.edu.cn 


\title{
The impact of domestic portfolio diversification strategies in Toronto stock exchange on Canadian textile manufacturing industry
}

\author{
DOI: 10.35530/IT.071.03.1696
}

The impact of domestic portfolio diversification strategies in Toronto stock exchange on Canadian textile manufacturing industry

The aim of this research study is to examine the impact of domestic portfolio diversification strategies in Toronto Stock Exchange (TSX) on Canadian textile manufacturing industry in order to obtain attractive investment opportunities. Dissipation of benefits of globally diversified portfolios due to overwhelming convergence among the international and regional stock markets around the globe have given rebirth to the idea of domestic portfolio diversification particularly after the global financial crisis of 2008. Textile industry in Canada is challenging but can achieve higher performance based on Toronto Stock Exchange behavior. Therefore, this is a complex applied research focused on investigating TSX as standalone stock market for domestic diversification opportunities. For this purpose, correlation coefficients, pairwise cointegration, multiple cointegration and causality of sectors in TSX have been examined. The empirical results show that majority of the sectors in TSX do not share high correlation with each other and they are also not highly cointegrated. These empirical findings indicate that TSX presents attractive opportunities for domestic portfolio diversification.

Keywords: TSX, cointegration, Granger causality test, global financial crisis, international diversification of investment portfolios

Impactul strategiilor de diversificare internă a portfoliului de pe piața bursieră din Toronto asupra industriei textile din Canada

Obiectivul acestui studiu de cercetare este de a analiza impactul strategiilor interne de diversificare a portofoliului de pe piața bursieră din Toronto (TSX) asupra industriei textile din Canada, pentru a identifica oportunități investiționale atractive. Disiparea profitului portofoliilor diversificate la nivel global, datorită convergenței semnificative existente între piețele bursiere regionale și internaționale, a condus la renaşterea ideii de diversificare internă a portofoliului, în special după criza financiară globală din anul 2008. Industria textilă din Canada reprezintă o provocare, dar se poate obține un nivel mai ridicat de performanță pe baza dinamicii comportamentului Bursei de Valori din Toronto. În consecință, acest studiu reprezintă o cercetare aplicativă complexă focalizată pe investigarea comportamentului TSX ca piață bursieră de sine stătătoare, pentru identificarea oportunităților interne de diversificare a portofoliului. În acest scop, s-au analizat coeficienții de corelație, cointegrarea și relațiile de cauzalitate existente la nivelul sectoarelor de activitate ale TSX. Rezultatele empirice arată că majoritatea sectoarelor din TSX nu indică o corelație semnificativă și, de asemenea, nu prezintă un nivel foarte ridicat de cointegrare. Aceste constatări empirice sugerează faptul că TSX prezintă oportunități atractive pentru diversificarea internă a portofoliului investițional.

Cuvinte-cheie: TSX, cointegrare, testul de cauzalitate Granger, criză financiară globală, diversificarea internațională a portofoliului investitional

\section{INTRODUCTION}

Portfolio formation and its management is one of the widely debated and researched topics across the financial fraternity. From investor's view point, choosing stocks for portfolio formation is one of the important decisions. Before the emergence of Modern Portfolio Theory (MPT afterwards) designed by Harry Markowitz in 1952 to use time horizons for financial markets, investments were regarded as standalone securities without realizing the concept of portfolio. MPT introduced a new concept to institutional and individual investors alike in the field of investments by giving the understanding of correlations among stocks and their prices. This concept enabled the potential investors to look at systematic risk as only priced risk in the context of extremely diversified portfolio while diversifying away standalone risks of other securities by including uncorrelated securities. Following the footsteps of MPT, investors started diversifying their portfolio in the local stock market (also known as domestic diversification) only to use this concept to form a globally diversified portfolio at a later stage. International and cross border diversification opportunities started to see the light of the day in the 1980s when researchers, academicians and 
investors started to investigate integration among international stock markets. Global investors perceived the opportunity of investing in the international financial markets while holding a diversified portfolio and minimizing risk as fruitful and luxurious.

The trend of investing in the international stock markets exploded with the rise of emerging stock markets which provided better global diversification opportunities than the global investment opportunities offered by developed stock markets. Globalization, advent of multinational companies, electronic trading and better means of communication reduced blockade to international investment and only escalated and encouraged international portfolio diversification trend. As a result, an overwhelming surge in global diversification of portfolios has been observed. Such rapid, bulk and huge investment in this arena has made international stock markets more integrated while fading away the benefits of international diversification. High degree of integration was realized when most of the international developed and emerging financial stock markets experienced jolts of uncertainty, volatility and stock market crashes after the Asian financial crisis of 1997 and global financial crisis of 2008 which made investors and researchers realized that perhaps international portfolio diversification is not as effective as it used to be. Financial crises are caused by various cause such as: over shooting of markets, excessive leverage of debt and credit booms, miscalculation of risks, the rapid outflow of capital from a country (capital flight), mismatches between asset types, such as investing in short term assets to fund long term assets [1].

Despite the worldwide acceptance of MPT among researchers and practitioners, "under-diversification" is still a relevant phenomenon where investors do not diversify their portfolio to a larger extent.

The government of Canada stated that textile manufacturing industry in Canada comprises of establishments primarily engaged in manufacturing goods and products for traditional and non-traditional textile markets. Traditional textile markets are destined to apparel and accessories; households; furnishings; and floor coverings. Non-traditional markets are defined as technical textiles and "other valued-added textiles". The textile manufacturing industry exhibited limited growth in output between 2011 and 2015 while domestic market for textile goods and products increased by $\$ 1.4$ billion between 2011 and 2015. In case of developed countries such as Canada, there is a tendency to support the development of national systems with complex international interactions. Moreover, textile companies in Canada manufacture for a wide variety of technical and niche applications and are integral to the supply chains of the various important industries in this country.

The Canadian government suggested that advances in the global textile industry have resulted in textiles increasingly competing with other materials such as metals, wood, and plastics for applications that have traditionally been held by these other materials. Therefore, the management of any apparel/textile company has significantly endeavoured to improve, support and expand its activities, both in serving the domestic market and, most of all, with the aim to export and be competitive at the global market.

\section{LITERATURE REVIEW}

This literature review surveys the financial literature on financial integration among stock markets. It presents view of proponents and opponents of international financial integration of stock markets. Billio et al. [2] examined diversification opportunities among international stock markets and found that an increase in financial integration at international level would lead to decline in portfolio diversification internationally. These findings give rise to the idea of domestic diversification. However, international portfolio diversification has its advantages and disadvantages. Caporale et al. [3] found that financial integration is followed by financial disintegration. Menon et al. [4] suggested that national economies are responsive to international events and consequences of international events can effectively change the prices of securities in the stock market. Bundoo [5] examined diversification opportunities between US stock market and Southern African stock markets and concluded that stock markets in southern Africa are not cointegrated with the stock markets of US. Moreover, Moerman [6] revealed that sectorial portfolio diversification's benefits outperformed international portfolio diversification's benefits. Therefore, the aim of this empirical research study is to examine the stock market of Toronto Stock Exchange (TSX hereafter) for domestic sectorial diversification opportunities regarding textile industry.

On the other hand, Balli et al. [7] examined ASEAN stock markets for domestic and international sectorial diversification opportunities and reported that domestic diversification outperformed international sectorial diversification. Alam et al. [8] investigated the sectorial performance of conventional and Islamic indices. They found that in short run conventional and Islamic indices follow same patterns of efficiency and perform well. However, Islamic indices remain attractive and proved to be resilient throughout the sample period which lead to a finding that Islamic indices are weakly form efficiency market. As per best of our knowledge, there is no study in recent financial literature which has examined the TSX for domestic sectorial diversification opportunities. It is the first attempt to expose the TSX as standalone stock market to sectorial diversification opportunities. In this study, domestic sectorial integration opportunities will be examined through multiple and pairwise cointegration and granger causality tests among sectors of TSX.

Domestic portfolio diversification opportunities will be examined through the sectors of TSX. It will be 
examined if the sectors of TSX are highly correlated or not. Similarly, pairwise and multiple cointegration among sectors will be examined to inspect if sectors offer diversification opportunities or not. Sectors' causality will also be examined through granger causality test. Toronto stock exchange is a thriving stock exchange and is also the largest stock exchange in the world by number of listed companies. TSX presents a great domestic sectorial diversification opportunity for academics as well as domestic institutional and individual investors. According to official statistics, Toronto Stock Exchange is one of the global leaders in diversified industries, including companies involved in relevant areas such as: communications and media, consumer products and services, financial services, industrial products and services (includes also manufacturing companies), and real estate.

\section{DATA AND METHODOLOGY}

Toronto Stock Exchange or TSX, hereafter, has been selected to examine the domestic diversification opportunities among sectors. The index is TSX composite. Daily stock prices of the companies have been downloaded from Datastream on sectorial basis. Time period of the data started from December $1^{\text {st }}, 2008$ and ended on March $8^{\text {th }}, 2019$ [9-10]. In order to check for the diversification among sectors, price weighted index has been developed. It is developed by calculating the average prices of companies in each sector on daily basis. The return of these average prices is calculated to get returns of price weighted index. Following formula has been used to calculate returns:

$$
\text { Returns }=\frac{\text { Index }_{t}-\text { Index }_{t-1}}{\text { Index }_{t-1}} \times 100
$$

where: Index $t$ is closing index and Index $t-1$ - opening index.

The total number of activity sectors included on TSE is 20 and total number of companies in all 20 sectors for the above-mentioned time period is 356 . The exact situation is provided in table 1. To examine domestic diversification opportunities among sectors of TSE, pairwise correlation, cointegration and causality tests have been run and their results are examined. For analytical purposes, the following statistical and econometrics technique have been applied using STATA econometric software.

\section{Correlation matrix}

Correlation measures how two stocks are closely related. It captures the movement of two stocks. Its value ranges from +1 to -1 . The value +1 indicates that stocks have tandem movements whereas -1 shows that movements of two stocks are not tandem. 0 correlation coefficient indicates that there is no relationship in two stocks. Marokowitz's Modern Portfolio Theory considers correlation as its integral part and states that investor should go for diversification when

\begin{tabular}{|c|c|}
\hline \multicolumn{2}{|c|}{ SECTORS AND NUMBER OF COMPANIES } \\
\hline Sector & No. of companies \\
\hline Air Space and Defence & 8 \\
\hline Alternative Energy & 9 \\
\hline Automobile and Parts & 6 \\
\hline Beverages & 9 \\
\hline Chemical & 12 \\
\hline Construction and Material & 23 \\
\hline Electricity & 17 \\
\hline Electronic and Electrical Material & 21 \\
\hline Fixed line and Telecommunication & 3 \\
\hline Food and Drug Retailers & 8 \\
\hline Food Producers & 22 \\
\hline Forestry and Paper & 12 \\
\hline Gas, Water and Multi Utilities & 6 \\
\hline General Industries & 8 \\
\hline General Retailers & 25 \\
\hline Health Care Equipment Services & 38 \\
\hline Industrial Engineering & 24 \\
\hline Oil Equip and Services & 46 \\
\hline Personal Goods & 5 \\
\hline Pharmaceutical and Biotechnology & 54 \\
\hline Total & 356 \\
\hline
\end{tabular}

correlation coefficient between two securities is low. MPT theory used the following equation to measure the portfolio's variance [11]:

$$
\sigma 2 p=\omega 2 A \sigma 2 A+\omega 2 \sigma 2 B+2 \omega A \omega B \sigma A \sigma B \rho A B
$$

where $\sigma 2 p$ is variance of portfolio, $\omega 2 A$ - weight of a security in portfolio and $\rho$-correlation coefficient.

\section{Unit root test}

Efficient market hypothesis [12] states that stock prices reflect all private and publicly available information. Information efficiency is divided in three main categories, such as: weak form, semi-strong form and strong form [13]. Efficient market hypothesis includes some essential aspects such as: investor rationality, uncorrelated errors, and the assumption that there are no limits to arbitrage [14]. Unit root test is applied to examine the stationarity of the data. Dickey Fuller test is used frequently to examine the stationarity of time series data. It may or may not reveal trend in the data which indicates inefficiency in sectors. Unit root test has null and alternate hypothesis. Its null hypothesis states that data is non stationary:

$$
y t=\rho y t-1+\mu t
$$

where $y$ - sector index for a given day, $y t-1$ - sector index for previous day, $\rho$ - co-efficient and $\mu t$ - error term. 
Johansen's multivariate co integration test

If two sectors have tandem movements and are showing the tendency of moving together, they are said to be integrated. To examine the equilibrium relationship in short run and long run among non-stationary indices of all sectors, Johansen's Multivariate Co-integration Test will be examined as follows:

$$
\lambda \text { trace }=-T \sum \ln (1-\lambda i)
$$

where $\lambda i$ is estimated eigen value and $\lambda$ trace - trace statistic.

\section{Granger Causality Test}

This test is used to determine how one sector is impacting the other sector. There may be a unidirectional or bi-directional relationship between two sectors, if they are integrated. Unidirectional sector indicates that one sector is impacting the other sector whereas bi directional relationship among both sectors shows that both are impacting each other.

\section{EMPIRICAL RESULTS}

The following table 2 provides descriptive statistics of selected databases based on stock returns. It shows the mean daily return of the sectors. Health care equipment services sector is posting the highest average return which is $0.105 \%$ followed by automobile parts sector which posted a return of $0.095 \%$. The table also shows standard deviation value. Standard deviation value shows how volatile the sector is. It shows that highest volatile sector is health care equipment services which is posting standard deviation value of 4.535 followed by Pharmaceutical and Biotechnology sector with standard deviation value of 2.98. It is important to note the health care equipment services sector is the one with highest return and it is also the most volatile sector as well. The table also shows the minimum and maximum returns for each sector. Interestingly, healthcare services sector is the one which has posted lowest minimum and highest maximum return which is $-57.73709 \%$ and $51.13089 \%$ respectively.

The correlation matrix examines the relationship between two sectors. It shows that if two sectors are related to each other or not? It inspects if two sectors dependent upon each other or not. Correlation's coefficients values range from +1 to -1 . +1 coefficient value suggests that there is a strong relationship between two sectors and -1 coefficient value states that two sectors are independent of each other. Airspace and Defence sector does not share strong relationship with any sector. It is not highly correlated with any sector. Similarly, Alternative energy sector is not highly correlated with any sector. It is clear from the table that the correlation coefficients among sectors are extremely low. The general trend from the table shows low correlation coefficient values for all the sectors. It means that all the sectors are not highly correlated with each other, in other words, they are independent of each other. Correlation coefficient results suggest that TSE presents excellent domestic diversification opportunity among sectors because their movements are not tandems. It means that loss of investment in one sector will not put the investment

Table 2

\begin{tabular}{|l|c|c|c|c|c|}
\hline \multicolumn{7}{|c|}{ DESCRIPTIVE STATISTICS } \\
\hline \multicolumn{1}{|c|}{ Sector name } & Obs. & Mean (\%) & Std. dev. & Min (\%) & Max (\%) \\
\hline Air Space and Defence & 2679 & 0.055647 & 1.279235 & -15.2679 & 9.346304 \\
\hline Alternative Energy & 2679 & 0.026001 & 2.760541 & -18.7148 & 19.74444 \\
\hline Automobile and Parts & 2679 & 0.095963 & 1.750812 & -9.03341 & 11.50117 \\
\hline Beverages & 2679 & 0.040732 & 0.8380914 & -5.60183 & 4.894431 \\
\hline Chemical & 2679 & 0.053355 & 1.517616 & -7.71385 & 6.452939 \\
\hline Construction and Material & 2679 & 0.033793 & 1.548734 & -12.5662 & 16.35021 \\
\hline Electricity & 2679 & -0.02469 & 3.360679 & -28.6107 & 52.5243 \\
\hline Electronic and Electrical Material & 2679 & 0.012184 & 1.299013 & -8.34414 & 8.115792 \\
\hline Fixed line and Telecommunication & 2679 & 0.038065 & 0.8373267 & -5.75896 & 7.186808 \\
\hline Food and Drug Retailers & 2679 & 0.041232 & 0.8114182 & -5.01 & 4.565838 \\
\hline Food Producers & 2679 & 0.034508 & 0.906451 & -5.81748 & 4.144572 \\
\hline Forestry and Paper & 2679 & 0.045439 & 1.528355 & -9.28537 & 6.995167 \\
\hline Gas, Water and Multi Utilities & 2679 & 0.010186 & 1.779282 & -9.38685 & 18.04949 \\
\hline General Industries & 2679 & 0.07842 & 1.521718 & -9.90595 & 8.653371 \\
\hline General Retailers & 2679 & 0.04426 & 0.7015473 & -3.68192 & 3.389365 \\
\hline Health Care Equipment Services & 2679 & 0.105062 & 4.535045 & -57.7371 & 51.13089 \\
\hline Industrial Engineering & 2679 & 0.034942 & 0.9846312 & -4.91691 & 5.10728 \\
\hline Oil Equip and Services & 2679 & 0.022193 & 0.9342339 & -5.70999 & 4.631205 \\
\hline Personal Goods & 2679 & 0.06548 & 2.053176 & -23.6146 & 25.76177 \\
\hline Pharmaceutical and Biotechnology & 2679 & -0.01149 & 2.948174 & -53.3728 & 22.57859 \\
\hline
\end{tabular}


at risk in the other sector since there is no strong correlation among activity sectors.

Table 3 provides empirical results on stationarity based on Unit Root Test at Level 0 and Level 1. Cointegration will be examined among sectors. One of the pre-conditions of co-integration test is data must be stationary. Time series grows in value if data is not stationary. In order to run co-integration test, several times series should be stationary at same level. To examine whether times series is stationary or not, Dicky-fuller test has been used. Hypothesis for Dickey-fuller test is data has a unit root which indicates that time series is not stationary. For data to be stationary at $1 \%$ level of significance with critical value of -3.430 , the $t$-stat value of time series must be less than critical value with $p$ value less than $5 \%$.
Above table shows that all sectors are non-stationary at level 0 because $t$-stat value is greater than critical value with $p$ value greater $5 \%$. The results show that null hypothesis could not be rejected, and time series has unit root hence data is nonstationary. However, all-time series are found to be stationary at first order difference because $t$ stat value is lower than critical value with $0 p$ value which is lower than $5 \%$ which indicates that null hypothesis is rejected, time series is stationary at level 1.

Table 4 provides empirical results on VAR Lag length Selection Criteria. The precondition of co-integration and granger causality test is to determine the lag length, after that, it will be determined if two sectors are integrated or not. VAR lag length test is used to select the lag length for the granger causality test.

Table 3

\begin{tabular}{|c|c|c|c|c|c|c|c|}
\hline \multicolumn{8}{|c|}{ STATIONARITY CHECK: UNIT ROOT TEST AT LEVEL 0 AND LEVEL 1} \\
\hline \multirow{2}{*}{ Sector name } & \multirow{2}{*}{$\begin{array}{l}1 \% \text { Critical } \\
\text { value }\end{array}$} & \multicolumn{2}{|c|}{ Level 0} & \multirow{2}{*}{ Remarks } & \multicolumn{2}{|c|}{ Level 1} & \multirow{2}{*}{ Remarks } \\
\hline & & t-stat & prob. & & t-stat & prob. & \\
\hline Air Space and Defence & -3.43 & -0.705 & 0.8454 & Non stationary & -51.617 & 0 & Stationary \\
\hline Alternative Energy & -3.43 & -2.742 & 0.067 & Non stationary & -55.124 & 0 & Stationary \\
\hline Automobile and Parts & -3.43 & -1.485 & 0.5409 & Non stationary & -49.192 & 0 & Stationary \\
\hline Beverages & -3.43 & -1.058 & 0.7315 & Non stationary & -52.738 & 0 & Stationary \\
\hline Chemical & -3.43 & -2.059 & 0.2613 & Non stationary & -48.751 & 0 & Stationary \\
\hline Construction and Material & -3.43 & -2.787 & 0.0602 & Non stationary & -56.213 & 0 & Stationary \\
\hline Electricity & -3.43 & -1.206 & 0.671 & Non stationary & -57.134 & 0 & Stationary \\
\hline Electronic and Electrical Material & -3.43 & -2.015 & 0.2802 & Non stationary & $-50.9-$ & 0 & Stationary \\
\hline Fixed line and Telecommunication & -3.43 & -1.3 & 0.6292 & Non stationary & -52.833 & 0 & Stationary \\
\hline Food and Drug Retailers & -3.43 & -0.392 & 0.9114 & Non stationary & -51.339 & 0 & Stationary \\
\hline Food Producers & -3.43 & -1.717 & 0.4225 & Non stationary & -49.793 & 0 & Stationary \\
\hline Forestry and Paper & -3.43 & -1.998 & 0.2875 & Non stationary & -48.536 & 0 & Stationary \\
\hline Gas, Water and Multi Utilities & -3.43 & -2.362 & 0.1529 & Non stationary & -55.349 & 0 & Stationary \\
\hline General Industries & -3.43 & -0.456 & 0.9004 & Non stationary & -51.315 & 0 & Stationary \\
\hline General Retailers & -3.43 & -0.971 & 0.7637 & Non stationary & -47.805 & 0 & Stationary \\
\hline Health Care Equipment Services & -3.43 & -1.515 & 0.5258 & Non stationary & -52.17 & 0 & Stationary \\
\hline Industrial Engineering & -3.43 & -2.48 & 0.1204 & Non stationary & -47.731 & 0 & Stationary \\
\hline Oil Equip and Services & -3.43 & -2.013 & 0.2811 & Non stationary & -47.012 & 0 & Stationary \\
\hline Personal Goods & -3.43 & -0.44 & 0.9032 & Non stationary & -54.739 & 0 & Stationary \\
\hline Pharmaceutical and Biotechnology & -3.43 & -1.929 & 0.3185 & Non stationary & -51.873 & 0 & Stationary \\
\hline \multicolumn{8}{|c|}{$1 \%$ Critical value $=-3.430$} \\
\hline
\end{tabular}

Table 4

\begin{tabular}{|c|c|c|c|c|c|c|c|c|}
\hline \multicolumn{9}{|c|}{ VAR LAG LENGTH SELECTION CRITERIA } \\
\hline Lag & LL & LR & df & $\mathbf{p}$ & FPE & AIC & HQIC & SBIC \\
\hline 0 & -82384.9 & - & - & - & 125.286 & 61.5881 & 61.6041 & 61.6322 \\
\hline 1 & 25600.1 & $2.20 E+05$ & 400 & 0 & $1.5 e-33^{*}$ & $-18.8192^{*}$ & $-18.4847^{*}$ & $-17.8945^{*}$ \\
\hline 2 & 25947.8 & 695.34 & 400 & 0 & 1.60E-33 & -18.7801 & -18.1269 & -16.9746 \\
\hline 3 & 26178.4 & 461.17 & 400 & 0.019 & 1.80E-33 & -18.6535 & -17.6817 & -15.9673 \\
\hline 4 & 26432.2 & $507.56^{*}$ & 400 & 0 & 2.00E-33 & -18.5442 & -17.2537 & -14.9773 \\
\hline
\end{tabular}

Note: * indicates lag order selected by the criterion 
Five methods are used in the tests when it comes to selecting the lag length number. These methods are LR test Statistics, Final Predication Error (FPE), Akaike information Criterion (AIC), Schwarz Bayesian information criterion (SBIC) and Hannan-Quinn information criterion (HQIC). Rule of thumb suggests that lag length will be selected which has a support of most tests or methods. It is clear from the table that FPE, AIC, SBIC and HQIC are supporting lag length 2 and it should be selected whereas LR test is supporting lag length 4 . Therefore, lag length 1 will be selected for empirical analysis.

Table 5 provides empirical results on Multivariate Johansen's Co-integration Tests. The interpretation of the Johansen's Multivariate Co-integration tests depends on Trace Statistics or Eigen Value. The null hypothesis for Trace Statistics is that there is no cointegration among sectors and alternate hypothesis states that there is minimum one co-integration among sectors. For Eigen value, hypothesis is same as the hypothesis of Trace Statistics as far as null hypothesis is concerned, however, its alternate hypothesis is different than the alternate hypothesis of Eigen value. Alternate hypothesis of Eigen value states that there is only one co-integration exists. For co-integration to exist, Trace Statistics value should be less than critical value for the given rank. The rank represents the number of possible co-integrated equations. Eigen value suggests that no cointegra- tion exists in two sectors. Similarly, trace statistics value suggests that series are not cointegrated with each other. Pairwise co-integration will be run to examine if individual sectors are co-integrated with each other or not.

Pairwise Co-integration test has been run to examine if one sector is integrated to another sector. If the one sector is integrated to another sector, provided they are statistically significant, then, diversification cannot happen between them. For diversification to happen, a sector must be statistically significant and must not be co-integrated to another sector. If sectors are co-integrated to each other or not. * sign indicates that values are significant. Rank " 0 " indicates that there is no co-integration and " 1 " indicates that there is co-integration. Some pairwise co-integration sectors have results which are statistically not significant. One pair is alternative energy sector and gas and water and multi utilities sector, second pair is chemical sector and construction and material sector, third pair is chemical sector and industrial engineering sector and fourth pair is construction material sector and industrial engineering sector. The empirical results revealed that there is no relationship between the pairs mentioned above.

According to our empirical analysis 11 pairs of sectors are co-integrated with each other whereas rest of the pair sectors are not co-integrated with each other. It is clear that most of the pair sectors are significant and are not co-integrated, as well which can provide a great diversification opportunity. For instance, air space and defence sector are not co-integrated with each other which presents a great diversification opportunity. It means that if a portfolio manager has invested in both above mentioned sector, a loss in one sector can be off-set with the profit in another sector. However, some pair of sectors are co-integrated. For instance, construction material and electricity are co-integrated with each other which means there is no diversification opportunity between these two sectors and perhaps the loss in one sector will also lead to loss in another sector. TSE presents excellent opportunity for diversification because most pair sectors are not statistically significant and have no co-integration with each other. In order to determine if one sector causes another sector in short run and if the series can be used for forecasting purposes, granger causality test is run. Granger causality test has null and alternate hypothesis. Its null hypothesis states that no granger causality among specific sectors. To prove that there is granger causality 
between two sectors, null hypothesis should be rejected when p-value is less than $5 \%$. Like any other test, it has its short coming. For instance, it only gives information about existence or non-existence of Granger causality, but it is silent on coefficient of causality. It is important to remember that relationship between two sectors in granger causality test is unidirectional which means one sector causes another sector but not the other way around. It is clear from the results that some sectors cause other sectors. For instance, air space and defence sector cause alternative energy sector. It also causes beverages sector, forestry and paper, general industries and general retailers sectors respectively. But the relationship is unidirectional. It means that there exists a causality between air and defence sector and sectors it has relationship with, but this relationship is unidirectional not a bidirectional and this relationship only exists in short run. It indicates that a rise or fall in prices of air and defence sector may cause rice or fall in the prices of other sector with whom it shares a unidirectional relationship. But two things are important to note here. Firstly, a rise or fall in the prices fair and defence sector and other sectors with whom it has unidirectional relationship is only established in short run and secondly, the rise and fall in prices of other sectors, with whom air and defence sector shares a relationship, is caused by a rise and fall in prices of air and defence sector since the relationship is unidirectional only. Therefore, diversification is not possible in short run with air and defence sectors and sectors associated with it through a unidirectional relationship.

Similar trend can be observed in other sectors as well. For instance, alternative energy sector causes "food producers" sector and forestry and paper sector causes construction material sector and food and "drug retailers" sectors. Therefore, diversification cannot happen for a portfolio manager in such sectors in short run. However, diversification is possible in such sectors where unidirectional relationship and granger causality do not exist among sectors. For example, Alternative energy sector does not share any unidirectional relationship with any sector other than "food producers" sector. It means portfolio manager, or an investor can diversify the portfolio by investing in alternative energy sector and other sectors as well. This trend is also observable throughout the table. Many sectors in TSE present a fruitful diversification opportunity. All the empirical results suggest that TSE is an attractive stock market for domestic portfolio diversification. It gives fruitful diversification opportunities to investors who invest domestically for diversification and maximize their portfolio wealth without investing in international stock markets. It is evidenced from the results of multivariate cointegration tests, pairwise cointegration tests and granger causality tests that TSE has ample amount of domestic diversification opportunities in short run and long run. Most of its sectors are not cointegrated to each other which provides an excellent opportunity for investors to maximize their portfolios' value. These findings are line with the findings of previous literature on domestic diversification opportunities.

\section{CONCLUSIONS}

In 1952, Harry Markowitz has made a significant contribution to financial economics by introducing the new idea of portfolio selection and diversification. Since then investors started looking investment opportunities and offsetting their risk by diversifying their portfolios regionally and globally. International portfolio diversification started in early 1980s and reached its peak in 2000s resulting in overwhelming financial integration among international and regional stock markets. As a result of extreme convergence among stock markets, benefits of global portfolio diversification started to dissipate, and this notion was further confirmed by Asian financial crisis of 1997 and global financial crisis of 2008. Due to frequent financial crisis, high uncertainty at political arena and extreme integration among financial markets, the idea of domestic portfolio integration started getting attention day by day. Therefore, this study aims to study domestic portfolio diversification opportunities in the TSX. It is a prosperous stock exchange which offers ample amount of diversification opportunities in domestic context. In order to identify diversification opportunities in TSX of Canada, correlation coefficients of the sectors have been examined using correlation tests. Their pairwise and multiple cointegration have also been examined and causality among sectors have also been tested through granger causality test. It is very clear from the results that TSX offers excellent domestic portfolio diversification opportunities. Most of its sector does not share high correlation with each other and they are also not highly cointegrated with each other which means that investors can diversify their portfolio by investing in different sectors and maximize their portfolios' wealth. Future research should focus on predicting the future trends of the sectors of TSX in order to make the investment horizon more certain and avoiding any volatilities in stock prices. Textile industry in Canada is challenging, rather heterogeneous and not very representative but can achieve higher performance based on optimizing investments on Toronto Stock Exchange of Canada.

\section{REFERENCES}

[1] Naeem, M.Z., Spulbar, C., Birau, R., Ejaz, A., Minea, E.L., Imran, A.I., Disseminating the History of the Major Financial Crises and Their Multidimensional Implications, In: Revista de Științe Politice. Revue des Sciences Politiques, 2019, 64, 12-34 
[2] Billio, M., Donadelli. M., Paradiso, A., Riedel, M. Which market integration measure?, In: Journal of Banking and Finance, 2017, 76, 150-174

[3] Caporale, G.M., Erdogan, B., Kuzin, V., Testing stock market convergence: a non-linear factor approach, In: Empirica, 2015, 42, 481-498

[4] Menon, N.R., Subha, M.V., Sagaran, S., Cointegration of Indian stock markets with other leading stock markets, In: Studies in Economics and Finance, 2009, 26, 2, 87-94

[5] Bundoo, S.K., Stock market development and integration in SADC (Southern African development Community), In: Review of Development Finance, 2017, 7, 64-72

[6] Moerman, G.A., Diversification in Euro Area stock markets: Country vs. industry, In: Journal of International Money and Finance, 2008, 27, 1122-1134

[7] Balli, F., Balli, H.O., Luu, M.N., Diversification across ASEAN-wide sectoral and national equity returns, In: Economic Modelling, 2014, 41, 398-407

[8] Alam, N., Arshad, S., Rizvi, S.A., Do Islamic stock indices perform better than conventional counterparts? An empirical investigation of sectoral efficiency, In: Review of Financial Economics, 2016, 31, 108-114

[9] Official website of the Toronto Stock Exchange of Canada, Available at: https://www.tsx.com/ [Accessed April 2019]

[10] Official website of the government of Canada, Available at: https://www.ic.gc.ca/ [Accessed April 2019]

[11] Markowitz, H., Portfolio Selection, In: Journal of Finance, 1952, 7, 1, 77-91

[12] Fama, E., Random Walks in Stock Market Prices, In: Financial Analysts Journal, 1965, 21, 5, 55-59

[13] Spulbar, C., Birau, R., Emerging Research on Monetary Policy, Banking, and Financial Markets, In: IGI Global USA, 2019, 322, http://doi.org/10.4018/978-1-5225-9269-3

[14] Spulbar, C., Ejaz, A., Birau, R., Trivedi, J., Sustainable Investing Based on Momentum Strategies in Emerging Stock Markets: A Case Study for Bombay Stock Exchange (BSE) of India, In: Scientific Annals of Economics and Business, 2019, XX, X, 1-11, http://doi.org/10.2478/saeb-2019-0029

\section{Authors:}

ABDULLAH EJAZ¹, RAMONA BIRAU², CRISTI SPULBAR ${ }^{3}$, RAMONA BUDA $^{4}$, ANDREI COSMIN TENEA ${ }^{3}$

${ }^{1}$ Bredin College of Business and Health Care, Edmonton, AB, Canada e-mail: ejazabdullah03@gmail.com;

${ }^{2}$ Faculty of Social Science, University of Craiova, 200585, Craiova, Romania

${ }^{3}$ University of Craiova, Faculty of Economics and Business Administration, 200585, Craiova, Romania

e-mail: cristi_spulbar@yahoo.com, andrei.tenea@ymail.com

${ }^{4}$ Robertson College, Canada

e-mail: ramonabuda@hotmail.com

Corresponding author:

BIRAU RAMONA

e-mail: ramona.f.birau@gmail.com 


\title{
Breaking force analysis of cotton ring-spun yarns
}

\author{
DOI: 10.35530/IT.071.03.1650
}

\section{ABSTRACT - REZUMAT}

\section{Breaking force analysis of cotton ring-spun yarns}

The most important factor influencing the production efficiency of final textile products made from yarns as well as the product performance are the tensile properties of the yarn. The breaking force of spun yarns, assessed with standard static procedure, depends on several parameters, one of them being the testing conditions. In our research, the effect of testing conditions (climatic conditions, the ratio gauge length/constant rate of extension and sampling, which refers to the number of yarn package and the position of package winding, taken from the bobbin) on the breaking force of $100 \%$ cotton ring-spun yarns was analyzed using the statistical evaluation method "ANOVA". The results clearly indicate that indeed all input parameters of testing conditions have a statistically significant effect on the breaking force of the yarn. When we judge the suitability of yarns to withstand a certain tension produced by technological procedures, not only average breaking force should be focused on. The information regarding the tested minimum breaking force of yarn becomes very important regarding our decision whether yarn fulfills the prescribed value of breaking force.

Keywords: ring-spun yarns, breaking force, testing conditions

\section{Analiza privind rezistența la rupere a firelor din bumbac filate cu inele}

Cel mai important factor care influențează eficiența producției de produse textile finale obținute din fire, precum și performanța produsului este reprezentat de proprietățile de tracțiune ale firelor. Rezistența la rupere a firelor filate, evaluată cu procedura statică standard, depinde de mai mulți parametri, unul dintre aceștia fiind condițiile de testare. În această lucrare a fost analizată, folosind metoda de evaluare statistică „ANOVA”, influența condițiilor de testare (condițiile climatice, raportul dintre distanța între cleme și viteza constantă a alungirii epruvetei și eșantionarea, care se referă la numărul de formate de fire și poziția înfășurării firelor, preluate din bobină), asupra rezistenței la rupere a firelor filate cu inele, din 100\% fibre de bumbac. Rezultatele au indicat clar că, într-adevăr, toți parametrii de intrare ai condițiilor de testare au un efect semnificativ statistic asupra rezistenței la rupere a firului. Atunci când se evaluează capacitatea firelor de a rezista la o anumită solicitare produsă în timpul proceselor tehnologice, nu trebuie să se țină cont numai de forța de rupere medie. Informațiile privind forța de rupere minimă obținută la testarea firelor devin foarte importante pentru a decide dacă firul corespunde valorii impuse pentru rezistența la rupere.

Cuvinte-cheie: fire filate cu inele, rezistență la rupere, condiții de testare

\section{INTRODUCTION}

The tensile properties of spun yarns are one of the basic performance properties of a product and as such, are important not just in the case of post spinning mechanical operations (like warping, weaving, braiding, knitting, production of direct oriented structures and composites), but also in operations needed to assemble the yarns into a final product. For example, spun yarns are used in the production of women's tampons, where inappropriate or insufficient yarn tensile strength can lead to the breaking of yarns, and consequently, to a lower efficiency of production. Tensile properties are characterized by two parameters: a) breaking tenacity, which is a ratio between breaking load and yarn linear density, expressed in N/tex, and b) breaking strain, which is a ratio between breaking extension and initial length of yarn, expressed in \% [1]. Breaking strength could be also expressed as absolute value, e.g. as breaking force, which is the maximum force applied to the testing yarn in a tensile test carried to rupture, expressed in $\mathrm{cN}$ or $\mathrm{N}$. There are several factors, which have an impact on the tensile properties of spun yarn. These can be grouped into the following categories: a) properties of spinning material (tensile strength of used fibers, fiber length, fiber cross-section etc.); b) yarn structure (arrangement of fibers in the yarn, yarn fineness, the number of fibers in yarn cross-section, adhesion, twist, type of spinning technologies, yarn irregularities); c) testing conditions (gauge length, rate of extension/loading, humidity, temperature, the manner of sampling).

In a standard test procedure, a gauge length of 500 $\mathrm{mm}$ is employed, whilst having $20 \pm 2 \mathrm{~s}$ of time available in order to cause breaking. A clamped yarn breaks in its weakest point according to the principle of the "weakest link" and this strength value is then assigned to the whole length of yarn [2]. As the test sample is gripped at the two ends and maintains such a static state during the duration of the testing process, the evaluated tensile properties are treated as static tensile properties [3]. It is worth mentioning that in actual practice the yarns undergo stress and strains that are substantially different from those 


\begin{tabular}{|l|c|}
\hline \multicolumn{2}{|c|}{ TEST OF NULL HYPOTHESES } \\
\hline \multicolumn{1}{|c|}{ Null hypotheses $-\mathbf{H}_{0}$} & Confirmation of $\mathbf{H}_{0}$ \\
\hline Climatic conditions don't have an effect on yarn braking strength & no \\
\hline Gauge length/rate of extension doesn't have an effect on yarn breaking strength & no \\
\hline Number of the package doesn't have an effect on yarn breaking strength & no \\
\hline The position of package winding doesn't have an effect on yarn breaking strength & \\
\hline
\end{tabular}

applied in standard testing conditions. Therefore, the results obtained under a standard test method cannot always be expected to fully reflect the end-use performance of the yarns [4]. The tensile strength and breaking extension of the yarns are not unique functions, but they are dependent upon the rate of extension and gauge length. To compare tensile properties of yarns, it is thus important to indicate if the tester uses a constant rate of loading (CRL) or a constant rate of extension (CRE) [5], and what is the distance between gauges. The results of some researches indicate the following:

- yarn tenacity increases with the extension rate for all spinning system [4] and that the relationship between yarn tenacity and the logarithm of rate of extension is approximately linear [6]; the effect of rate of extension on breaking extension is lesser than its effect on strength [7];

- yarn tenacity decreases with higher gauge length for ring and friction spinning systems; the strength of ring- and friction-spun yarns show a sharp drop, as the gauge length increases from $1 \mathrm{~mm}$ to $40 \mathrm{~mm}$ and from $1 \mathrm{~mm}$ to $20 \mathrm{~mm}$, respectively; as for gauge length greater than $40 \mathrm{~mm}$, the strength of ringspun yarns appears fairly constant, whereas the strength of friction-spun yarns is reduced continuously with the increase of gauge length [8].

In this work, the influence of testing conditions (climatic conditions, gauge length/rate of extension, the number of package, the position of package winding taken from the bobbin) on the breaking force of ringspun yarns produced from cotton fibers have been analyzed. The ANOVA statistical method has been used to assess the significance of the individual parameter.

\section{MATERIALS AND METHODS}

Carded, bleached and hydrophobic (Sevophob) $100 \%$ cotton ring-spun yarns used for the production of women's tampons were analyzed in this research. The fineness of used yarns was $60 \times 4$ tex. Breaking force was measured according to the ISO 2062 from the same yarn lot using Tinius Olsen universal tester (Model H10KT) under following testing conditions:

- climatic conditions: standard $(65 \pm 2 \%$ relative humidity; $\left.20 \pm 2^{\circ} \mathrm{C}\right)$ and non-standard conditions $(40 \pm 2 \%$ relative humidity; $23 \pm 2^{\circ} \mathrm{C}$ );

- gauge length - constant rate of extension: $200 \mathrm{~mm}$ - $100 \mathrm{~mm} / \mathrm{min} ; 250 \mathrm{~mm}-250 \mathrm{~mm} / \mathrm{min}$, and 500 $\mathrm{mm}-500 \mathrm{~mm} / \mathrm{min}$;
- number of the package: No. 1, No. 2, and No. 3;

- position of package winding taken from the bobbin: outer, middle, and inner winding;

- number of measurements per sample: 60 .

Altogether $3240(60 \times 2 \times 3 \times 3 \times 3)$ tests were conducted to determine the mean value of breaking force and elongation of tested spun yarns. To determine if there was any difference among the testing conditions according to the breaking force of spun yarns and to test null hypotheses (table 1), analysis of variance procedure (ANOVA) was performed using IBM SPSS 22 statistical software package. The selected value of significance level for this procedure was 0.05 (or $95 \%$ confidence level).

\section{RESULTS AND DISCUSSIONS}

The results of ANOVA analysis are presented in table 1. The input parameters (climatic conditions, gauge length/rate of extension, the number of the package and the position of package winding taken from the bobbin) with $p$-values lower than 0.05 are expected to be significant. Since the results showed that all input parameters had $p$-value lower than 0.05 , all null hypotheses were rejected. This means that testing conditions significantly affect the yarn breaking force at $95 \%$ of confidence level.

\section{The effect of climatic conditions}

Figure 1 shows the results of breaking force of cotton yarns regarding the standard and non-standard climatic conditions at different positions of package winding. The breaking force measured by standard climatic conditions is higher than by non-standard climatic conditions. Cotton yarns absorb more water vapour at higher relative humidity, thus resulting in

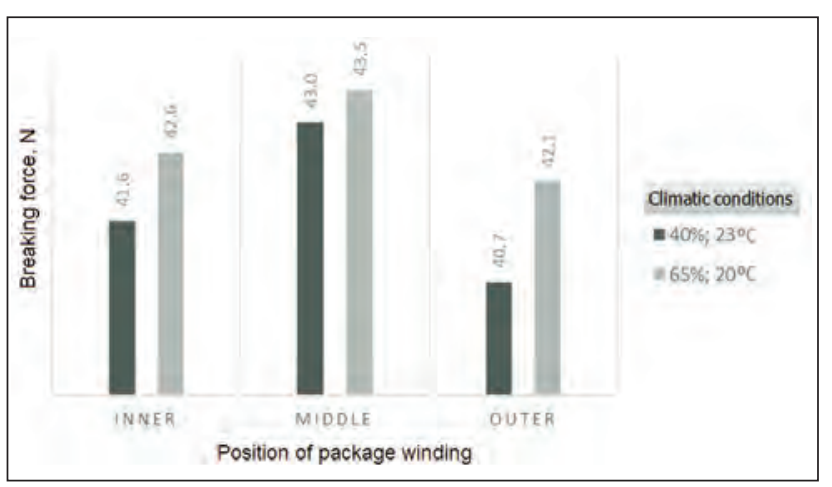

Fig. 1. The effect of climatic conditions on yarn breaking force 
higher breaking strength. This is valid for all positions of package windings.

\section{The effect of gauge length/rate of extension}

Figure 2 shows the results of breaking force of cotton yarns regarding the gauge length - GL/constant rate of extension - CRE at different number of the package.

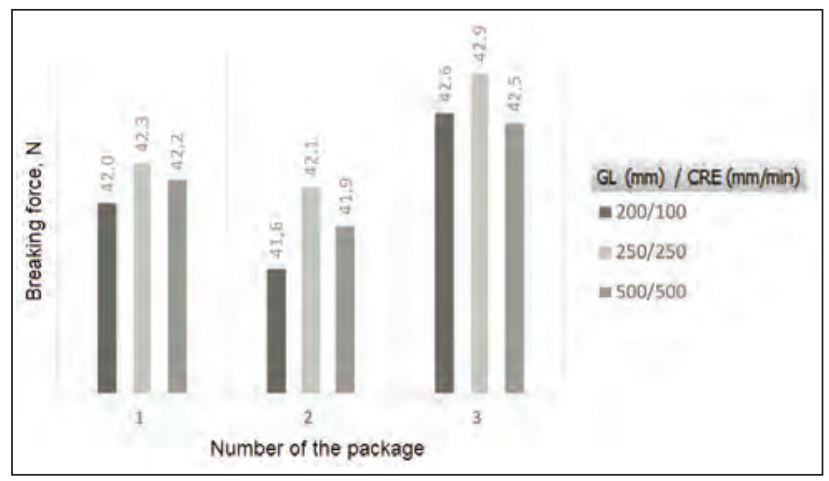

Fig. 2. The effect of gauge length/rate of extension on yarn breaking force

We should have in mind that the rate of extension was not the same during the increase of gauge length from $200 \mathrm{~mm}$ to $500 \mathrm{~mm}$. The ratio between the gauge length and the constant rate of extension was 2, 1 and 1 for 200, 250 and $500 \mathrm{~mm}$ of gauge length, respectively (table 2 ).

Table 2

\begin{tabular}{|c|c|c|}
\hline \multicolumn{2}{|c|}{ GAUGE LENGTH AND RATE OF EXTENSION RATIO } \\
\hline $\begin{array}{c}\text { Gauge length - } \\
\text { GL (mm) / constant } \\
\text { rate of extension - } \\
\text { CRE (mm/min) }\end{array}$ & $\begin{array}{c}\text { Ratio } \\
\text { GL/CRE }\end{array}$ & $\begin{array}{c}\text { Ratio } \\
\text { CRE/GL }\end{array}$ \\
\hline $200 / 100$ & 2 & 0.5 \\
\hline $250 / 250$ & 1 & 1 \\
\hline $500 / 500$ & 1 & 1 \\
\hline
\end{tabular}

If we compare the results of breaking force for yarns with the same ratio between the gauge length and rate of extension, this following conclusion can be made: yarn breaking force decreases with higher gauge length (from 250 to 500). At higher gauge lengths, there is more slippage and breakage of fibers compared to shorter gauge lengths. If we observe the ratio between the constant rate of extension and gauge length, we can conclude that these ratios were $0.5,1$ and 1 for 200,250 and $500 \mathrm{~mm}$ of gauge length, respectively. If we compare the results of breaking force for yarns with an increasing ratio between the constant rate of extension and gauge length, this following conclusion can be made: yarn breaking force increases with increasing constant rate of extension per gauge length. This is valid mostly for all numbers of the yarn package. As the rate of extension increases, the percentage of ruptured fibres increases (the inter-fibre pressure tends to increase), resulting in a higher breaking force, while greater numbers of fibres are contributing to the breaking load.

\section{The effect of sampling}

According to the standard, sampling should be performed according to the procedures; namely if only mean values are required, then 10 packages shall be taken from the bulk sample, distributed as evenly as possible among the cases and among the levels in each case. In our case, 3 bobbins (packages) were taken from the testing material, marked as package 1 , package 2 and package 3 . Then, from each package, the appropriate lengths of yarn were taken at three different positions of package winding, namely: from the outer, middle and inner package winding. From each package winding position, 60 specimens were tested. Figures 3 and 4 show the results of breaking force of cotton yarns in regards to the number of package and the position of package winding taken from the bobbin (outer, middle, and inner winding) at different climatic conditions, respectively.

From the figure 3 , the differences between the packages can be seen, which are according to the ANOVA analysis, statistically important.

Results show that the middle package winding has the highest breaking force in comparison with the outer and inner package winding, thus implying that yarn structure in the middle of the bobbin is more homogenous, with less weak points. We assume that in this case the tension at winding was not kept at the

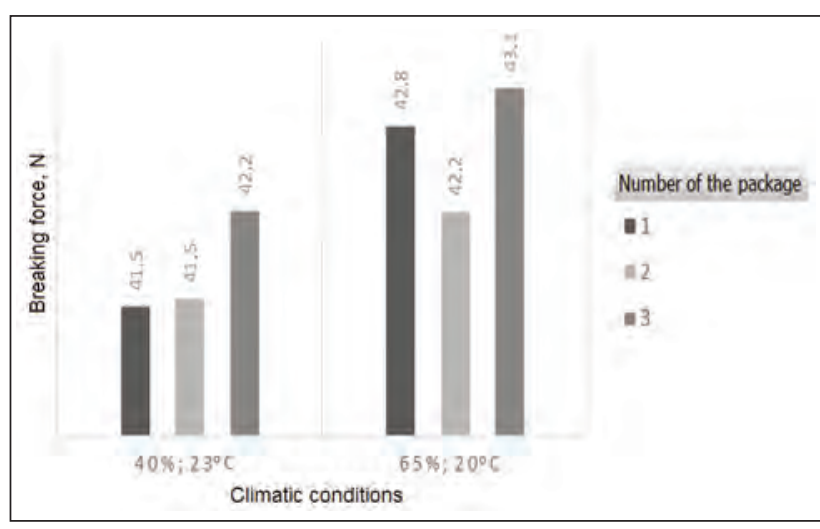

Fig. 3. The effect of the number of yarn package on yarn breaking force

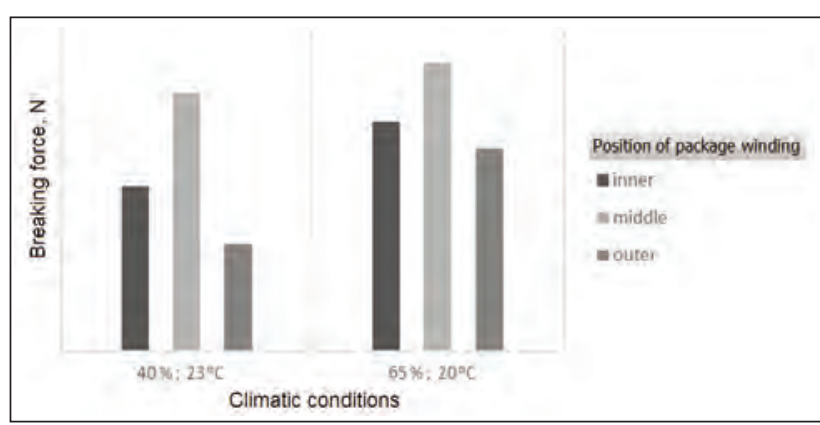

Fig. 4. The effect of the position of package winding on yarn breaking force 
same level with the increase of bobbin diameter, thus resulting in different yarn breaking strength. Yarn damage is highest at yarn taken from the outer package winding.

\section{CONCLUSIONS}

The breaking strength of spun yarns is essential during the production of the final product. Consequently, it is important to use those yarns, which will be able to maintain tension produced by technological processes. There are several factors influencing the breaking strength of yarns; one of them is testing conditions. In our research, the testing conditions, namely climatic conditions, the gauge length/constant rate of extension, the number of bobbin (package), the position of package winding taken from the bobbin, were analyzed using standard static test procedure and statistical evaluation of the results (ANOVA analysis). The results clearly indicate that all input parameters of testing conditions have a statistically significant effect on the yarn breaking force (95\% confidence level). This implies that even if the declared breaking force of spun yarns is achieved (assessed with standard test procedure), the results cannot be taken as reliable in actual practice, as they are dependent upon our subjective decision - which package we will take from the lot and how evenly we will take the yarn from the packages. For the producers of the final product, the information regarding the tested minimum breaking strength of yarns is more appropriate in comparison to mean breaking strength, when we judge the suitability of yarn to withstand a certain tension produced by technological procedures.

\section{ACKNOWLEDGEMENT}

The author acknowledges the financial support from the Slovenian Research Agency (research core funding No. P2-0063).

\section{REFERENCES}

[1] Ghosh, A., Majumdar, A., Characterizing the Tensile Properties of Spun Yarns Using Bivariate Normal Distribution. In: Fibers and Polymers, 2010, 11, 4, 642-647

[2] Lizàk, P., Yarn Strength Dependence on Test Length, In: Fibers \& Textiles in Eastern Europe, 2002, 38, 3, 32-34

[3] Das, B.R., Ishtiaque, S.M., Rengasamy, R.S., Study on the Static and Dynamic Strength and Weavability of Spun Yarns, In: Fibers and Polymers, 2012, 13, 2, 231-236

[4] Ghosh, A., Ishtiaque, S.M., Rengasamy, R.S., Analysis of Spun Yarn Failure. Part I: Tensile Failure of yarns as a Function of Structure and Testing Parameters, In: Textile Research Journal, 2005, 75, 10, 731-740

[5] Das, B.R., Tensile Behavior of Spun Yarns under Static State, In: Journal of Engineered Fibers and Fabrics, 2010 , $5,1,1-9$

[6] Meredith, R., The Effects of Rate of Extension on the Tensile Behavior of Viscose and Acetate Rayons, Silk and Nylon, In: Journal of the Textile Institute, 1954, 26, 4, 354-357

[7] Majumdar, A., Assessment of Tensile Properties of Cotton Yarns, In: Indian Journal of Fiber \& Textile Research, 2001, 11, 4, 642-647

[8] Oxenham, W., Zhu, R.Y., Leaf, G.A.V., Observation on the Tensile Properties of Friction-Spun Yarns, In: Journal of the Textile Institute, 1992, 83, 4, 621-623

\section{Author:}

\section{POLONA DOBNIK DUBROVSKI}

University of Maribor, Faculty of Mechanical Engineering, Textile Materials and Design Department, Smetanova ulica 17, 2000, Maribor, Slovenia

\section{Corresponding author:}

POLONA DOBNIK DUBROVSKI

e-mail: polona.dubrovski@um.si 


\title{
Green dyeing of microwave treated silk using coconut coir based tannin natural dye
}

\author{
DOI: 10.35530/IT.071.03.1666
}

\author{
SHUMAILA KIRAN \\ SHAHID ADEEL \\ MUHAMMAD SAJJAD YOUSAF \\ NOMAN HABIB
}

\author{
ATYA HASSAN \\ MUHAMMAD ABDUL QAYYUM \\ MUHAMMAD ABDULLAH
}

\section{ABSTRACT - REZUMAT}

Green dyeing of microwave treated silk using coconut coir based tannin natural dye

The resurgence of natural dyes is gaining fame in textile industry due to eco-friendly nature. The present study was done to investigate the Coconut coir as natural dye (tannin) for silk dyeing under Microwave (MW) treatment following the optimization of experimental parameters. Isolation of colorant was carried out in aqueous, acidic and organic media (methanol) under influence of MW treatment up to 6 minutes. Dyeing of silk was carried out having irradiated and unirradiated extracts. Good colour strength was achieved by dyeing unirradiated silk using methanolic extract under MW treatment for 4 minutes at $75^{\circ} \mathrm{C}$. The optimal dyeing was achieved at 75 minutes at $\mathrm{pH} 8$ while keeping fabric liquor ratio $1: 25$ having $5 \mathrm{~g} / 100 \mathrm{ml}$ table salt as an electrolyte. For development of shades, salts of $\mathrm{Al}$ and Fe and Tannic acid were used as pre- and post-chemical mordants and Acacia, Pomegranate, Turmeric and Henna as pre- and post-biomordents. Acacia (6\%) as pre-bio mordant and Turmeric (6\%) as post-bio mordant considerably improved the colour strength at optimal conditions utilizing irradiated extract of coconut coir (tannin) and un-irradiated silk under MW treatment at 4 minutes. ISO-standard shows good colour fastness and colour strength at optimal conditions using Acacia and Turmeric as bio-mordents. This research work gives information about tannin extracted from Coconut coir has great potential to dye silk fabric to produce reddish-brown colour under the influence of microwave treatment. FTIR spectral study revealed chemical changes in the silk fabric treated with microwave radiations.

Keywords: coconut coir, microwave treatment, dyeing, silk, chemical mordents, bio-mordants, K/S value, colour fastness, FTIR

\section{Vopsirea ecologică a mătăsii tratate cu microunde folosind colorant natural tanin din nucă de cocos}

Coloranții naturali câștigă notorietate în industria textilă datorită naturii ecologice a acestora. Studiul de față a fost realizat pentru a investiga nuca de cocos în calitate de colorant natural (tanin), pentru vopsirea mătăsii sub tratament cu microunde (MW), în urma optimizării parametrilor experimentali. Izolarea colorantului a fost realizată în mediu apos, acid și organic (metanol), sub influența tratamentului MW, până la 6 minute. Vopsirea mătăsii s-a realizat cu extracte iradiate și neiradiate. O rezistență bună a culorii a fost obținută prin vopsirea mătăsii neiradiate folosind extract metanolic sub tratament $\mathrm{MW}$, timp de 4 minute la $75^{\circ} \mathrm{C}$. Vopsirea optimă a fost obținută după 75 minute cu un pH 8 , păstrând un raport de flotă de 1:25, folosind $5 \mathrm{~g} / 100 \mathrm{ml}$ sare de masă ca electrolit. Pentru dezvoltarea nuanțelor, sărurile de $A /$ și $F e$ și acidul tanic au fost utilizate ca pre- și post-mordanți chimici, iar salcâmul, rodia, curcuma și henna ca pre- și postbiomordanți. Salcâmul (6\%) ca pre-biomordant și curcuma (6\%) ca post-biomordant au îmbunătățit considerabil rezistența culorii în condiții optime, folosind extract iradiat de nucă de cocos (tanin) și mătase iradiată sub tratament MW la 4 minute. Conform standardului ISO se obține o rezistență a culorii în condiții optime, folosind salcâmul și curcuma ca bio-mordanți. Această lucrare de cercetare oferă informații despre taninul extras din nuca de cocos, care are un potențial semnificativ de a vopsi țesăturile din mătase, pentru a produce o culoare maro roșiatică sub influența tratamentului cu microunde. Studiul spectral FTIR a evidențiat modificări chimice ale țesăturii din mătase tratate cu radiații de microunde.

Cuvinte-cheie: nucă de cocos, tratament cu microunde, vopsire, mătase, mordanți chimici, bio-mordanți, valoare K/S, rezistența culorii, FTIR

\section{INTRODUCTION}

Natural dyes contain pure colorant components, which are non-hazardous to environment. Mostly, these colorants are obtained from self-growing plants and non-traditional crops [1]. Natural colours are famous for utilizing in colouring of food, leather and natural protein fabrics such as silk, wool and cotton [2], as synthetic dyes generate hazardous waste which is harmful for living environment [3-5]. But majority of common hues are taken from various parts of plants such as roots (Morinda tentoria), bark (Azadirachta indica), flowers (Solidago grandis) and leaves (Tectona grandis) etc. [6]. The colour of these dyes enhanced with the passage of time unlike their synthetic counter parts which fade with time [7]. People demand that colors must have appropriate 
shades and have capacity to fix with the substrate strongly [8]. The shade of coloured substance may not have influenced by drawn out presentation to light, soap, water and colour must have colour fastness properties [9]. Synthetic dyes are hazardous for the environment and are difficult to degrade [10]. Natural colorants are renewable, agro-renewable, and biodegradable, do not cause disposal problem because their wastes become the part of fertilizers and do not pose any threat to food [1]. Natural dyes are eco-friendly and eco-label in nature [1]. Application of natural dyes for textile fabrics acquire some techniques to utilize. Dyeing parameters are, therefore, necessary for obtaining ideal shades for textile processing [11].

Many laboratory techniques are to be utilized for enhancing the extraction of colorant, dyeing behaviour, colour properties, dye sorption, colour fastness and dye uptake for fibers [9]. Radiation is the proliferation and discharge of light as waves through various media. The medium might be a few materials or space. There are diverse sorts of radiation, for example, UV [12], gamma [13], microwave, ultrasonic [14-15]. The microwave heat is very fast technique because of no loss of heat and is safe to use. Microwave radiations had many advantages such as low cost, increase of colour fastness, dye uptake and consumed less energy, power and time [16]. It was observed that by increasing the power up to 700 increased the rate of extraction and give better yield. Microwave heat is distributed uniformly throughout the material and conventional or traditional heating only heat up the surface of material. Microwave radiations are the power source of noncontact heating and in the microwave field the substance that have permanent dipoles to rotate [17].

Silk is the insect fiber which is obtained from silkworm and used as textile fiber. Historically the silk fiber has been referred to as the queen of textiles [18]. Silk fabrics due to excellence performance such as softness, smoothness, luster, breathing ability, comfortableness and hygroscopicity have been used as a textiles material for thousands of years [12]. Coconut coir is a new dye yielding plant whose common name, scientific name and plant family is coir [19] Cocos nucifera and Arecaceae (Plam), respectively [20]. The husk contains tannin which acts as

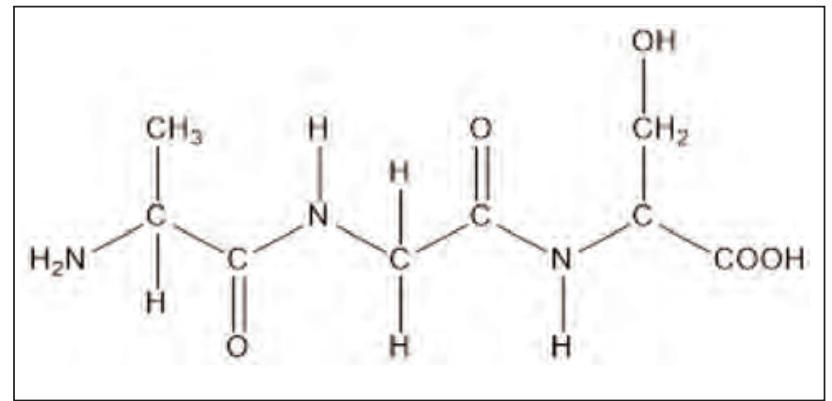

a colouring material to give brown colour on natural fabrics [21]. The alcoholic extracts of coconut husk possess antifungal and antimicrobial activities. It contains tannin as natural colorant which is used for dyeing of wool, silk and cotton (figure 1) [22].

Keeping in view the importance of natural colorants, the present study was focused:

1. To explore the extraction of microwave radiation for isolation and addition of herbal based bio-mordants of colorant from coconut coir using different media under microwave radiations.

2. To develop new shades using exploring of chemical and bio-mordents.

3. To improve the colour fastness properties of silk fabric using chemical and bio mordents.

\section{EXPERIMENTAL WORK}

\section{Materials and methods}

Coconut (Cocos nucifera) coir was collected from the Local Market Faisalabad, Pakistan. The coir was washed with water and dried under shade and cut into small pieces. The plant sources ground finely and went through a sifter of 20 work size to get powder of uniform size and stored in a plastic bag for further process of silk dyeing. Pre-treated silk fabric is purchased from local silk market in Fasialabad, Pakistan was dyed from the coconut coir.

\section{Optimization of extraction conditions under microwave irradiation}

The process of extraction of aqueous, acidic and organic (methanol) extracts were obtained from coconut coir by boiling $4 \mathrm{~g}$ of powder of coconut coir in $100 \mathrm{ml}$ of water for $60 \mathrm{~min}$. After boiling the flask were cooled and filtered. The filtrate was utilized for dyeing of natural silk fabric was treated with microwaves up to 1 to $6 \mathrm{~min}$. in a microwave oven (Orient Model ME-732 K) with power $800 \mathrm{~W}$ having frequency $450 \mathrm{MHz}$. Dyeing process was followed for treated and untreated silk fabrics [23].

It was found that optimized dyeing on silk fabric was achieved by utilizing methanolic media with $4 \mathrm{~min}$. treated with microwave radiations keeping temperature $75^{\circ} \mathrm{C}[24]$.

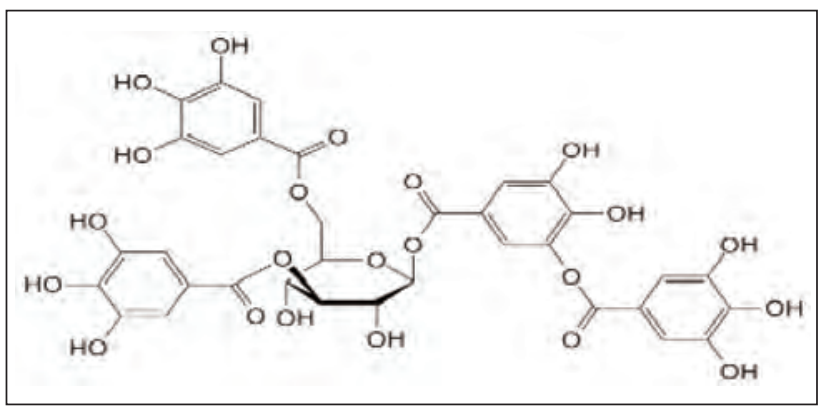

b

Fig. 1. Structure of: $a-$ silk; $b-$ tannin 


\section{Different dye bath parameters with mordents}

For optimum dyeing, different parameters like $\mathrm{pH}$ (1 to 9), Time (25 to $85 \mathrm{~min}$.), Temperature (25 to $\left.85^{\circ} \mathrm{C}\right)$ and $\mathrm{NaCl} \& \mathrm{Na}_{2} \mathrm{SO}_{4}(1-11 \mathrm{~g} / 100 \mathrm{ml})$ were applied [25]. In exhaust dyeing, salt is used as an electrolyte for level and uniform dyeing [26]. Dyeing process was completed for $75 \mathrm{~min}$. at $75^{\circ} \mathrm{C}$ [27]. Irradiated silk and un-irradiated silk was dyed by this dyeing process. Extracts of different chemical mordents (1 to $11 \mathrm{~g} / 100 \mathrm{ml}$ ) like $\mathrm{Al}$ [28], Fe [29] and Tannic acid and bio-mordents ( 1 to $11 \mathrm{~g} / 100 \mathrm{ml}$ ) like henna, acacia [12], pomegranate and turmeric [30] were also applied to improve in colour strength and fastness properties [31].

\section{Measuring colour strength and colour fastness properties}

Microwave treated and untreated silk fabrics were observed for colour strength and Lab values through Kubelka Munk equation computed in Spectra Flash (SF 600) at laboratory of the Noor Fatima Fabrics, Faisalabad, Punjab, Pakistan. Colour strength values were achieved from the equation [K/S $=(1-R) 2 / 2 R]$. ISO standard method for light (ISO 105-Bo2), rubbing (ISO 105-X12), washing (ISO 105 C03), dry cleaning (ISO 105D 01) and perspiration (ISO 105 EO4) fastness tests were used to investigate the colour fastness properties of dyed silk.

\section{FTIR analysis}

FTIR analysis was done to investigate the influence of the treatment with microwaves on the chemical structure of silk fibers. Experiments with silk fabric in a wet state under microwave irradiation for various lengths of time (1-6 min.) were carried out. This analysis uses infrared light to scan and observe chemical properties of samples. Samples were prepared using optimum irradiated microwave treatment for both silk and tannin dye solution. Control sample was also subjected to FTIR.

\section{RESULTS AND DISCUSSION}

Microwave irradiation improved the colour depth characteristics from the extract of coconut coir in methanolic media, when compared with other dyeing media. The results are shown in figure 2 .

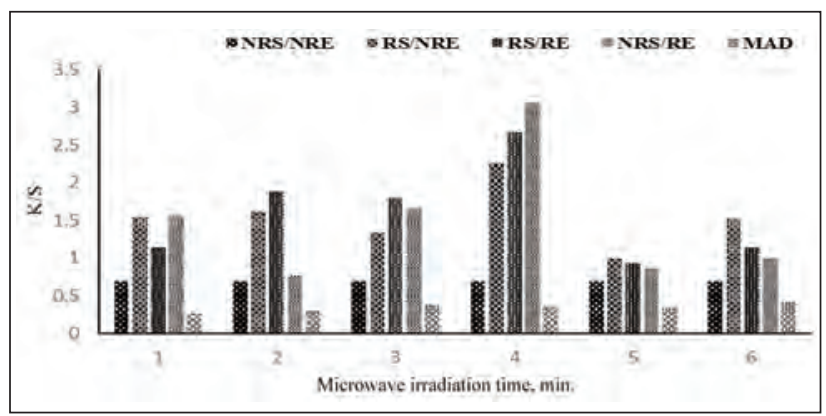

Fig. 2. Microwave treatment of pre-treated silk dyeing by methanolic extract of coconut coir: NRS - non-irradiated silk; NRE - non-irradiated extract; RS - irradiated silk; $\mathrm{RE}$ - irradiated extract
Colour characteristics of dyed silk fabric from the coconut coir in a methanol medium was enhanced by the presence of colouring part in coconut coir (phenol) which is more soluble in methanol medium [32]. During dyeing, colouring part from the coconut coir (tannin) makes strong bond with amino and carboxylic groups which are present in silk fabric. In other media impurities like dust, leaves of plants might be connected with the fabric and dye bath not make firm bonding resulted less colour depth [33]. In figure 2 result shows that high colour depth was achieved by utilizing MW treatment of $4 \mathrm{~min}$. on the silk fabric [34]. Microwave treated fabric enhanced the colour strength on the fabric by using pomegranate (Punica granatum L.) mentioned in literature [35]. However, high time microwave treatment of silk fabric not effect on the colour yields (figure 2). Similarly, low time contact of fabric under MW treatment not force the dye particles to sorb towards the fabric surface and treatment of fabric with microwave irradiation for more time period degrade the dye particles as well as he fabric surface, resulted decrease in yield of colour on silk fabric [36]. Overheating, from microwave treatment of fabric also swells the fabric surface, by which colour particles not make proper bonds with fabric [11].

\section{Optimization of experimental parameters}

$\mathrm{pH}$ in the dying bath also plays an important role in dyeing process. At optimum $\mathrm{pH}$ high colour strength is achieved on the coloured silk fabric. Role of optimum $\mathrm{pH}$ is that it accelerates the dye molecules towards the fabric surface for sorption. In figure 3, a data gives information that at $8 \mathrm{pH}$ maximum colour strength is measured as compared to the other $\mathrm{pH}$ conditions. Silk fabric is damaged on the more acidic $\mathrm{pH}$ because acid damage the silk structure [19]. So moderate $\mathrm{pH}$ was suitable for silk dyeing b/c dye molecules jump toward the fabric surface for sorption [37]. Moderate $\mathrm{pH}$ not damages the fabric surface [17]. Temperature is an important tool for the sorption of the dye particles to rush toward the fabric surface during dyeing process. Figure $3, b$ shows that best temperature for the dyeing of un-treated silk fabric under the influence of MW treatment was $75^{\circ} \mathrm{C}$ using treated methanol extract of coconut coir. It is evident from figure 5 at $75^{\circ} \mathrm{C}$ that $\mathrm{MW}$ radiations not accelerate colour particles to move on the fabric surface due to low rate of striking of dye particles and thus low colour values are obtained. Similarly, at high temperature $\left(85^{\circ} \mathrm{C}\right)$ fabric swell and change in structure both in fabric and dye particles resulted poor colour yield. Up to $75^{\circ} \mathrm{C}$, dye particles act as a unit molecule and properly absorbed on the silk fabric surface revealed the dark shade and optimal colour strength achieved [38]. In dyeing process, time parameter plays a significant impact on the fabric surface. When molecules of dye move on fabric surface it require time for making bond with fabric surface and for good sorption of the dye molecules [39]. Data given in figure 3, $C$ shows that optimal time for dye molecules to rush toward fabric for good sorption is $75 \mathrm{~min}$. Good 
colour strength of dyed silk obtained from spectra flash was at 75 min. in methanolic extract of coconut coir tannin based dye. Low dyeing time may not interact the dye molecules to rush toward the silk fabric. It may also reduce the kinetic energy of the dye molecules to sorption on the silk fabric [40]. Similarly, more dyeing time degrade the silk fabric and not favoured for sorb of the level dyeing on silk fabric. Long dyeing time may weak the $\mathrm{H}$-bonding between the dye molecules and silk fabric [41]. Hence, 75 min. is the suitable dyeing time for silk dyeing for good colour strength [11]. Adding of electrolyte in dye bath resulted in enhanced dyeing yield on silk fabric. Silk fabric produced poor colour strength contraction with colouring particle and less dye adsorbed on the fabric surface without using salt in dyeing process. However, adding electrolyte increases the dye particle adsorption on fabric. In figure $3, d$ shows that Table salt using in dyeing at $5 \mathrm{~g} / 100 \mathrm{ml}$ increased dye yield as compared the Glauber salt. It might be due to the fact that silk fabric acquired negative charge in methanolic medium and dye anions repulsion increased by fabric and not make firm bonding by colouring particles from dye towards the silk fabric [9, 42-43]. Role of using electrolyte in dyeing process is that it increases the anions on the fabric surface and minimize the force of repulsion between fabric and negative colouring particle charges and enhance the colour depth from dye bath toward the fabric surface. Low salt concentration ( 1 and $3 \mathrm{~g} / 100 \mathrm{ml}$ ) and high amounts $(7-11 \mathrm{~g} / 100 \mathrm{ml})$ not properly shift the dye particles towards the dye fabric surface because the dye equilibrium not produced between dye and fabric

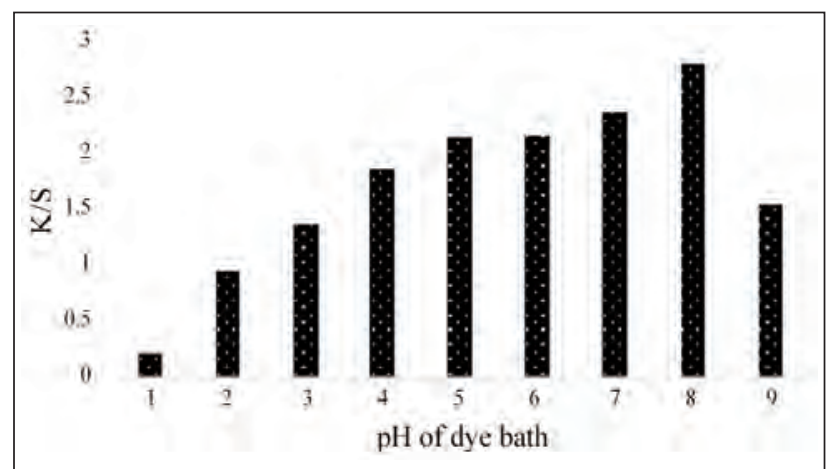

a

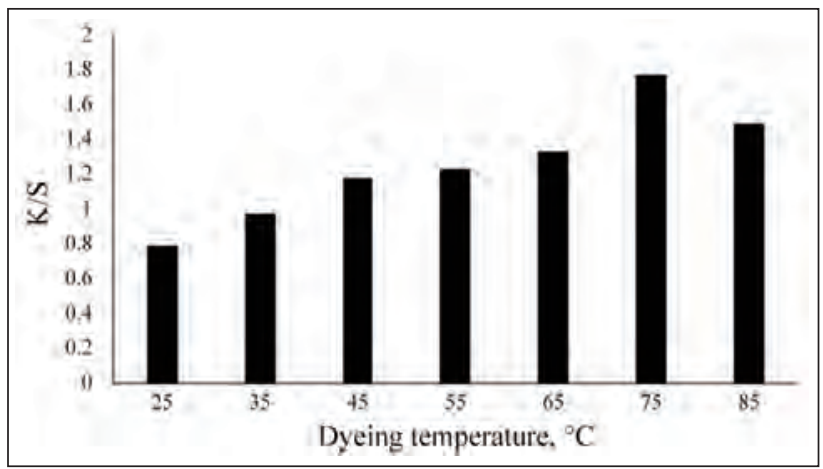

c therefore, less light shades achieved. In dyeing, treatment of microwave radiations decreases the salt consumption on the silk fabric [14]. Therefore, using $5 \mathrm{~g} / 100 \mathrm{ml}$ table salt enhanced the rate of exhaust dyeing of un-treated silk (NRS) with methanol extract of coconut coir (RE) under the influence of microwave treatment and utilized the fabric for future process for improvement in colour strength.

\section{Effect of chemical and bio-mordents on dyeing of silk fabric}

The pre-mordenting behavior of different chemical mordents (salts of Al \& Fe, Tannic acid) and bio-mordents (Acacia, Turmeric, Henna and Pomegranate) is shown in figure 4. Each chemical and bio-mordents enhanced colour strength on silk fabrics dyed with methanolic extract of coconut coir. However, Acacia (6\%) enhanced colour depth characteristics as compared to other mordents, when silk dyed from methanolic extract of coconut coir (figure 4,a). It might be due to the reason that dye particle tannin present in both coconut coir and acacia bark [43] results high shade strength and make firm bonding between fabric carboxylic group and phenolic groups present in the dye molecules [10]. In post-mordenting, Turmeric $(6 \%)$ exhibited good colour strength on the silk fabric as compared to the other chemical (Fe, Al and Tannic acid) and Bio (Henna, Pomegranate and $A$. nilotica bark) mordents (figure $4, b$ ). Turmeric as post-mordant makes strong $\mathrm{H}$-bonding with tannin dye particles and fabric surface. Turmeric also had potential to making complex bond with dye and fabric surface by this process, more colour sorbed on silk fabric and yellow colour produced rather than the

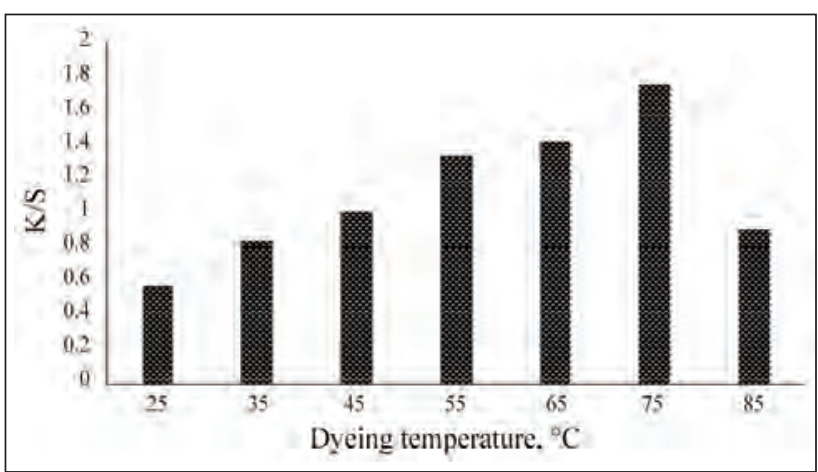
b

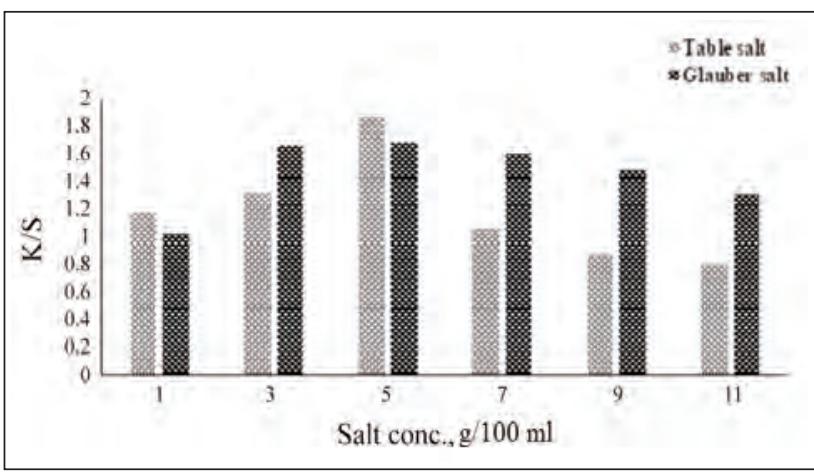

d

Fig. 3. Impacts of dyeing variables on the coloured silk fabric (NRS/RE) by extract of methanolic coconut coir 


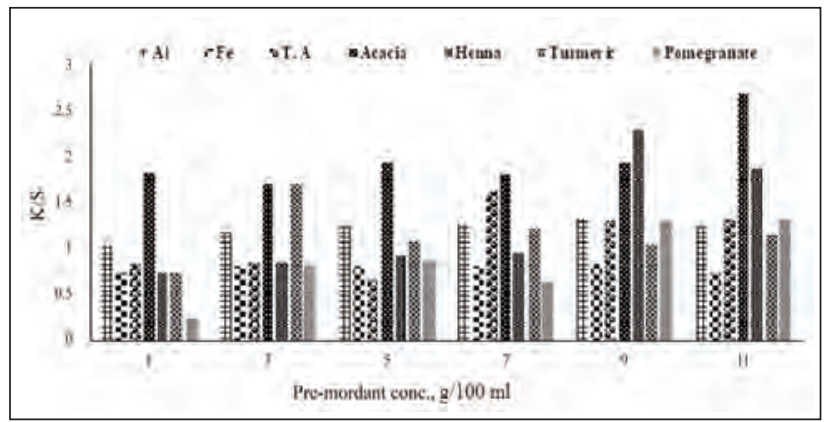

a

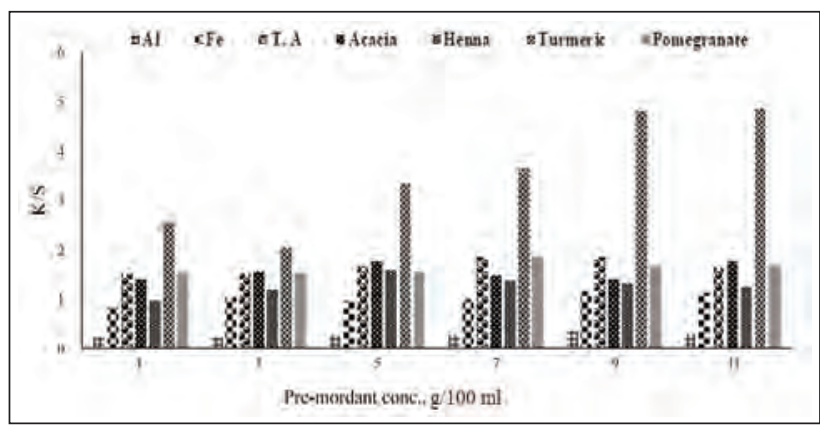

b

Fig. 4. Microwave treatment on the optimum silk dyed fabric 4 minutes (NRS/RE) of: $a$ - pre-mordants; $b$ - post-mordants

other mordents applied on the fabric with good shades strength [44-45]. It is found that low \% of chemical and bio-mordant using in silk dyeing may not made a firm stable complex with silk fabric and during washing easily washed the mordents from fabric surface and low K/S values achieved [9]. Thus, overall bio-mordents established high colour characteristics and fastness properties rather than the chemical mordents under the MW treatment of silk fabric [46]. Furthermore, Bio-mordents are more ecofriendly, sustainable and greener for the using silk dyeing under MW treatment [19].

\section{Fastness properties}

The fastness properties results show under the influence of MW treatment of methanol extract of coconut coir using untreated silk fabrics enhanced strength of colour and produced high colour depths (tables 1 and
2). This is because that methanolic extract of coconut coir for 4 minutes and mordented silk fabric make firm bonding with dye and silk fabric utilizing bio-mordents as compared to the chemical mordents due to the conjugation double bonds in natural dye (tannin in coconut coir) and auxochrome with stable complex formation of dye and chemical mordant on the silk fabric and strong $\mathrm{H}$-bonding with bio-mordents. They have resistance to eject colorant during applying fastness properties such as washing, rubbing and light [47].

Better colour strength achieved on the silk fabric to make good strength bond complex between dye and metal due to phenolic groups and double conjugate bond which present in dye molecules [48].Tannin which also present in dye molecules also had double conjugate bond helps to make firm bonding formation when bio-mordents are applied on silk fabric to

EFFECT OF CHEMICAL MORDANT BY MICROWAVE TREATMENT ON COLOUR STRENGTH VALUES OF UNTREATED SILK FABRIC UTILIZING TREATED EXTRACT OF METHANOLIC COCONUT COIR ON OPTIMAL PARAMETERS

\begin{tabular}{|c|c|c|c|c|c|c|c|c|c|c|c|c|c|c|}
\hline \multirow{3}{*}{$\begin{array}{l}\text { Chemical } \\
\text { mordant }\end{array}$} & \multicolumn{7}{|c|}{ Pre-mordanting } & \multicolumn{7}{|c|}{ Post-mordanting } \\
\hline & \multirow{2}{*}{ LF } & \multirow{2}{*}{ WF } & \multirow{2}{*}{ DRF } & \multirow{2}{*}{ WRF } & \multicolumn{2}{|c|}{ Perspiration } & \multirow{2}{*}{$\begin{array}{l}\text { Dry } \\
\text { clean }\end{array}$} & \multirow{2}{*}{ LF } & \multirow{2}{*}{ WF } & \multirow{2}{*}{ DRF } & \multirow{2}{*}{ WRF } & \multicolumn{2}{|c|}{ Perspiration } & \multirow{2}{*}{$\begin{array}{l}\text { Dry } \\
\text { clean }\end{array}$} \\
\hline & & & & & acid & alkaline & & & & & & acid & alkaline & \\
\hline Al & $4-5$ & 4 & 5 & 4 & $4-5$ & 4 & 4 & $4-5$ & $3-4$ & 4 & 3 & 4 & 3 & 4 \\
\hline $\mathrm{Fe}$ & 4 & $3-4$ & 4 & $3-5$ & 4 & $4-5$ & 5 & 4 & $4-5$ & 4 & $3-4$ & $4-5$ & 4 & $4-5$ \\
\hline TA & 4 & 4 & 5 & 4 & $4-5$ & 4 & $4-5$ & $3-4$ & $4-5$ & $4-5$ & $4-5$ & $3-4$ & 3 & 4 \\
\hline
\end{tabular}

EFFECT OF BIO MORDANT BY MICROWAVE TREATMENT ON COLOUR STRENGTH VALUES OF UNTREATED SILK FABRIC UTILIZING TREATED EXTRACT OF METHANOLIC COCONUT COIR ON OPTIMAL PARAMETERS

\begin{tabular}{|c|c|c|c|c|c|c|c|c|c|c|c|c|c|c|}
\hline \multirow{3}{*}{ Bio-mordant } & \multicolumn{7}{|c|}{ Pre-mordanting } & \multicolumn{7}{|c|}{ Post-mordanting } \\
\hline & \multirow{2}{*}{ LF } & \multirow{2}{*}{ WF } & \multirow{2}{*}{ DRF } & \multirow{2}{*}{ WRF } & \multicolumn{2}{|c|}{ Perspiration } & \multirow{2}{*}{$\begin{array}{c}\text { Dry } \\
\text { clean }\end{array}$} & \multirow{2}{*}{ LF } & \multirow{2}{*}{ WF } & \multirow{2}{*}{ DRF } & \multirow{2}{*}{ WRF } & \multicolumn{2}{|c|}{ Perspiration } & \multirow{2}{*}{$\begin{array}{c}\text { Dry } \\
\text { clean }\end{array}$} \\
\hline & & & & & acid & alkaline & & & & & & acid & alkaline & \\
\hline Acacia & $4-5$ & 4 & 5 & 4 & $4-5$ & 4 & 4 & $4-5$ & $3-4$ & 4 & $3-4$ & 4 & 4 & $3-4$ \\
\hline Henna & 4 & $3-4$ & 4 & $3-4$ & $3-4$ & $4-5$ & $4-5$ & 4 & $3-4$ & $4-5$ & 4 & $4-5$ & 4 & $4-5$ \\
\hline Turmeric & 4 & 4 & 5 & 4 & $4-5$ & 4 & $4-5$ & $3-4$ & $4-5$ & $4-5$ & 4 & $3-4$ & 3 & 4 \\
\hline Pomegranate & $3-4$ & $4-5$ & 4 & $3-4$ & 4 & $3-4$ & 4 & $4-5$ & 4 & 4 & $3-4$ & $4-5$ & $3-4$ & 4 \\
\hline
\end{tabular}




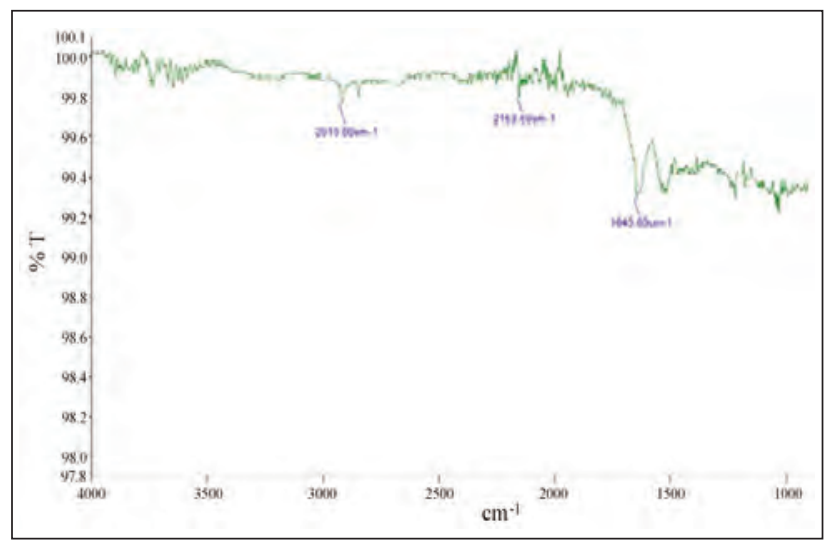

a

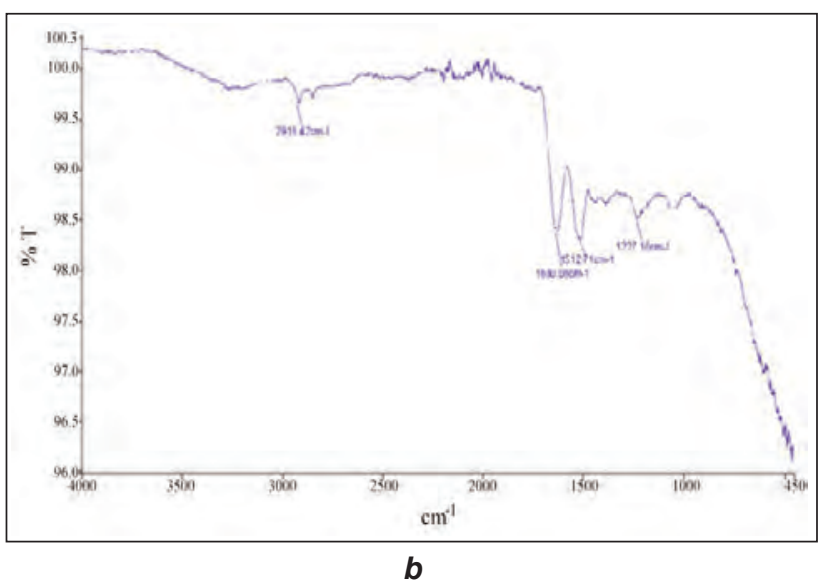

b

Fig. 5. FTIR of: $a$ - untreated silk; $b$ - microwave treated silk

improve the colour strength values [15]. Moreover, microwave treatment has ability to plays a major role enhancing colour fastness on silk fabrics. Hence, during silk dyeing MW treatment is greener, environment friendly and clean process that improved the fastness properties using coconut coir tannin based natural dye for silk dyeing [12].

\section{FTIR analysis}

FTIR analysis of untreated silk fabric and microwave treated silk fabric FTIR-ATR dyed with natural tannin dye extracted from Coconut coir are given in figure 5 . As it can be seen from figure 5, there are not any detectable significant changes in the FTIR spectra properties of microwave treated silk fabric after when compared with undyed silk fabric. According to FTIR spectra, the peaks ranged from $1630.08 \mathrm{~cm}^{-1}$, $1512.71 \mathrm{~cm}^{-1}, 1227.10 \mathrm{~cm}^{-1}$ due to C-C, C-N, and $\mathrm{N}-\mathrm{H}$ stress, are present in both untreated and microwave-treated silk fabrics depicting that MW radiation has nothing to do with the surface of the silk fabric chemically, It just physically modifies the structure of silk fabric which in turn enhanced the dye uptake capacity of silk fabric, resulting in improved colour shades of silk fabric.

\section{CONCLUSIONS}

It has been found that MW treatment during extraction and dyeing process of silk fabric by using natural coconut coir-based tannin dye has potential to dye silk fabric. This method is eco-friendly, green, less cost and less time-consuming process. Microwave assisted dyeing of silk fabric with methanolic extract of coconut coir using chemical and bio-mordants achieved reddish brown colour shades. The gaining of same colour via synthetic dyes is found to be more hazardous and non-ecofriendly. Methanolic extract of coconut coir at $\mathrm{pH} 8$ for 4 min. under MW treatment using $\mathrm{NaCl}(5 \mathrm{~g} / 100 \mathrm{ml})$ gave a good color strength and darker shade by dyeing unirradiated silk fabric for $75 \mathrm{~min}$. at $75^{\circ} \mathrm{C}$. Chemical mordants (Al, Fe and Tannic acid) and bio-mordants such as Henna, Pomegranate, Acacia and Turmeric also applied to improve the colour strength and make strong bonding with silk fabric but bio-mordents like Acacia bark gave excellent colour and high $\mathrm{K} / \mathrm{S}$ values. Furthermore, MW treatment has also tendency to improve the colour strength on silk using coconut coir extract as a natural dye under optimum conditions. More than that, the use of bio-mordants is non-hazardous for health and environment, green, eco-label and is cheaper for dyeing.

\section{ACKNOWLEDGEMENTS}

We are highly thankful to UNESCO for providing us funding to conduct the studies under PhosAgro/UNESCO/IUPAC/ GCUF Scheme Project No. 128. We are also thankful to Mr Zafar Iqbal Manager Noor Fatima Fabrics Faisalabad Pakistan and Mr Muhammad Abbas Chief Executive Harris Dyes and Chemicals Faisalabad Pakistan for technical and scientific guidance at industrial lab scale for running a part of UNESCO project.

\section{REFERENCES}

[1] Ibrahim, A.N., et al., Enhancing the UV protection and antibacterial properties of polyamide-6 fabric by natural dyeing, In: Textiles and Light Industrial Science and Technology, 2013, 2, 36-44

[2] Mongkholrattanasit, R., et al., Dyeing, fastness, and UV protection properties of silk and wool fabrics dyed with eucalyptus leaf extract by the exhaustion process, In: Fibers \& Textiles in Eastern Europe, 2011, 19, 94-99

[3] Gulzar, T., Kiran, S., Abrar, S., Rahmat, M., Haque, A., Nosheen, S., Ahmad, I., Rasul, S., Role of Enzymatic System of Screened Pleurots ostreatus IBL-02 in the Bio-Removal of Synthetic Dyes Effluent, In: J. Chem. Soc. Pak., 2019, 41, 3, 509-522

[4] Chatha, S.A.S, Kiran, S., Gulzar, T., Kamal, S., Ghaffar, A., Chatha, M.N., Comparative study on decolorisation and mineralization of synthetic and real textile effluents using advanced oxidation processes, In: Oxid. Commun., 2016, 39, 2, 1604-1614 
[5] Kiran, S., Huma, T., Jalal, F., Farooq, T., Hameed, A., Gulzar, T., Bashir, A., Rahmat, M., Rahmat, R., Rafique, M.A., Lignin degrading system of Phanerochaete chrysosporium and its exploitation for degradation of synthetic dyes wastewater, In: Pol. J. Environ. Stud., 2019, 28, 3, 1749-1757

[6] Datta, S., et al, Assessment of antimicrobial effectiveness of natural dyed fabrics, In: Bangladesh J. Sci. Ind. Res, 2013, 48, 3, 179-184

[7] Ado, A., Yahaya, H., Kwalli, A.A., Abdulkadir, R.S., Dyeing of textiles with eco-friendly natural dyes: a review, In: Int. J. Environ. Monit. Assess., 2014, 1, 76-81

[8] Yesmin, M.N., Uddin, S.N., Mubassara, S., Akond, M.A., Antioxidant and antibacterial activities of C. procera Linn, In: American-Eurasian J. Agri. Environ. Sci., 2008, 4, 5, 550-553

[9] Chengaiah, B., et al., Medicinal importance of natural dyes a review, In: Int. J. PharmTech. Res., 2010, 2, 1, $144-154$

[10] Kiran, S., et al., Recent trends in textile effluent treatments: A review, In: Advanced Materials for Wastewater Treatment, 2017, 29-49

[11] Adeel, S., et al., Dyeing of gamma irradiated cotton using Direct Yellow 12 and Direct Yellow 27: improvement in colour strength and fastness properties, In: Cellulose, 2015, 22, 2095-2105

[12] Jia, Y., et al., Dyeing characteristics and functionability of tussah silk fabric with oak bark extract, In: Textile Research Journal, 2017, 87, 1806-1817

[13] Gulzar, T., et al., Eco-friendly dyeing of gamma ray induced cotton using natural quercetin extracted from acacia bark (A. nilotica), In: J. Nat. Fibers, 2015, 12, 494-504

[14] Haji, A., Dyeing of Cotton Fabric with Natural Dyes Improved by Mordants and Plasma Treatment. Progress in Color, In: Colorants and Coatings, 2019, 12, 3, 191-201

[15] Adeel, S., Zuber, M., Zia, K.M., Microwave-assisted extraction and dyeing of chemical and bio-mordanted cotton fabric using harmal seeds as a source of natural dye, In: Environmental Science and Pollution Research, 2018, 25, $11100-11110$

[16] Haji, A., Nasiriboroumand, M., Qavamnia, S.S., Cotton Dyeing and Antibacterial Finishing Using Agricultural Waste by an Eco-friendly Process Optimized by Response Surface Methodology, In: Fibers and Polymers, 2018, 19, 11, 2359-2364

[17] Adeel, S., Bhatti, I.A., Zahid, M., Saba, S., Modification of cotton fabric for textile dyeing, industrial mercerization versus gamma irradiation, In: J. Text. Inst., 2017, 108, 287-292

[18] Kashyap, Dr.R., Sharma, N.., Lakshmi, S., Divya, Dyeing of Cotton with Natural Dye Extract from Coconut Husk, In: Int. J. Sci. Technol. Engng., 2016, 3, 92-95

[19] Kon, O., Eduok, U., Israel, A., Characterization and phytochemical screening of coconut (Cocos nucifera L.) Coir dust as a low cost adsorbent for waste water treatment, In: Elixir Appl. Chem., 2012, 47, 8961-8968

[20] Dyana, J.P., Kanchana, G., Preliminary phytochemical screening of Cocos nucifera L. flowers, In: International Journal of Current Pharmaceutical Research, 2012, 4, 3-4

[21] Singla, R.K., Jagani, H., Investigation of Antimicrobial Effect of Dry Distilled Extract of Cocos nucifera Linn Endocarp, In: Webmed Central Pharmac. Sci., 2012, 3, WMC002884

[22] Batool, F., et al., Gamma radiations induced improvement in dyeing properties and colorfastness of cotton fabrics dyed with chicken gizzard leaves extracts, In: Rad. Phy. Chem., 2013, 89, 33-37

[23] Adeel, S., et al., Dyeing of cotton fabric using UV irradiated turmeric (Curcuma longa L.) as natural dye, In: Res. J. Text. Apparel, 2011, 15, 71-76

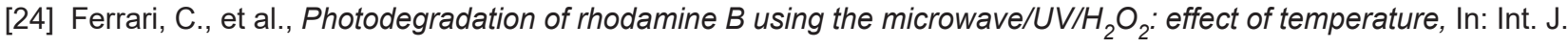
Photoen., 2013, 2, 123-127

[25] Khan A.A., et al., Extraction of natural dye from red calico leaves: Gamma ray assisted improvements in colour strength and fastness properties, In: Dyes and Pigments, 2014, 103, 50-54

[26] Israel, A.U., Ogali, R.E., Akaranta, O., Obot, I.B., Extraction and characterization of coconut (Cocos nucifera L.) coir dust, In: Songklanakarin J. Sci. Technol., 2011, 33, 717-724

[27] Doty, K., Haar, S., Kim J., Black walnut, Osage orange and eastern redcedar sawmill waste as natural dyes: effect of aluminum mordant on color parameters. In: Fashion and Text, 2016, 3, 1, 22

[28] Chhipa, M.K., Srivastav, S., Mehta, N., Study of dyeing of cotton fabric using peanut pod natural dyes using $\mathrm{Al}_{2}\left(\mathrm{SO}_{4}\right)_{3}, \mathrm{CuSO}_{4}$ and $\mathrm{FeSO}_{4}$ mordanting agents, In: Int. J. Environ. Agri. Res., 2017, 3, 2, 36-44

[29] Satyanarayana D.N.V., Chandra K.R., Dyeing of cotton cloth with natural dye extracted from pomegranate peel and its fastness, In: Int. J. Engng Sci. Res. Technol., 2013, 2, 2664-69

[30] Bhatti, I.A., et al., Influence of gamma radiation on the colour strength and fastness properties of fabric using turmeric (Curcuma longa L.) as natural dye, In: Rad. Phys. Chem., 2010, 79, 622-625

[31] Yusuf, M., Mohammad, F., Shabbir, M., Khan, M.A., Eco-dyeing of wool with Rubiacordifolia root extract: Assessment of the effect of Acacia catechu as biomordant on color and fastness properties, In: Text. Cloth. Sustain., 2017, 2, 10

[32] Wang, Y., Lee, C.H., Tang, Y.L., Kan, C.W., Dyeing cotton in alkane solvent using polyethylene glycol-based reverse micelle as reactive dye carrier, In: Cellulose, 2016, 23, 1, 965-980

[33] Hou, A., Wang, X., Wu, L., Effect of microwave irradiation on the physical properties and morphological structures of cotton cellulose, In: Carbohydrate Polym., 2008, 74, 934-937

[34] El-Khatib, E.M., Ali, N.F., Ramadan, M.A., Environmentally friendly dyeing of silk fabrics using microwave heating, In: Int. J. Curr. Microbiol. Appl. Sci., 2014, 3, 757-764 
[35] Sinha, K., Saha, P.D., Datta, S.S., Response surface optimization and artificial neural network modeling of microwave assisted natural dye extraction from pomegranate rind, In: Ind. Crops and Prod., 2012, 37, 1, 408-414

[36] Zhang, X., et al., Anti-hyperlipidemic effects and potential mechanisms of action of the caffeoylquinic acid-rich Pandanus tectorius fruit extract in hamsters fed a high fat-diet, In: PloS one, 2013, 8, 4, 61922

[37] Jose, S., Gurumallesh, H.P., Ammayappan, L., Eco-Friendly dyeing of silk and cotton textiles using combination of three natural colorants, In: J. Nat. Fib., 2017, 14, 1, 40-49

[38] Marie, M.M., Shokry, G.M., El-Khatib, H.S., Shahin, M.F., One bath cationization and dyeing of cotton fabric with Brazilwood natural dye, In: Int. J. Innov. Appl. Studies, 2015, 11, 928

[39] Periolatto, M., Ferrero, F., Migliavacca, G., Low temperature dyeing of wool fabric by acid dye after UV irradiation, In: The J. Text. Inst., 2014, 105, 10, 1058-1064

[40] Sun, S.S., Tang, R.C., Adsorption and UV protection properties of the extract from honeysuckle onto wool, In: Ind. Engng. Chem. Res., 2011, 50, 4217-4224

[41] Yusuf, M., et al., Dyeing studies with henna and madder: A research on effect of tin (II) chloride mordant, In: J. Saud. Chem. Soc., 2015, 19, 1, 64-72

[42] Iqbal, J., Bhatti, I.A., Adeel, S., Effect of UV radiation on dyeing of cotton fabric with extracts of henna leaves, 2008

[43] Adeel, S., Hanif, I., Zuber, M., Muneer, M., Ecofriendly Dyeing of UV-Irradiated Cotton Using Extracts of Acacia nilotica Bark (Kikar) as Source of Quercetin, In: Asian Journal of Chemistry, 2014, 26, 830-834

[44] Büyükakinci, B.Y., Investigation of antibacterial activities of tin ions on wool fabric, In: Industria Textila, 2013, 64, 5, 241-245

[45] Rather, L.J., et al., Ecological dyeing of Woolen yarn with Adhatodavasica natural dye in the presence of biomordants as an alternative copartner to metal mordants, In: J. Environ. Chem. Engng., 2016, 4, 3041-3049

[46] Adeel, S., et al, Microwave-assisted sustainable dyeing of wool fabric using cochineal-based carminic acid as natural colorant, In: J. Nat. Fiber, 2018, 1-9

[47] İşmal, Q.E., Greener natural dyeing pathway using a by-product of olive oil; prina and biomordants, In: Fibers and Polym., 2017, 18, 4, 773-785

[48] Ajmal, M., Modulation of pomegranate peel colourant characteristics for textile dyeing using high energy radiations, In: Ind. Crops and Production, 2014, 58, 188-193

Authors:

SHUMAILA KIRAN ${ }^{1}$, SHAHID ADEEL ${ }^{1}$, MUHAMMAD SAJJAD YOUSAF ${ }^{1}$, NOMAN HABIB ${ }^{2}$, ATYA HASSAN ${ }^{3}$, MUHAMMAD ABDUL QAYYUM ${ }^{4}$, MUHAMMAD ABDULLAH ${ }^{5}$

${ }^{1}$ Department of Applied Chemistry, Government College University, Faisalabad, Pakistan e-mail: shahidadeel@gcuf.edu.pk, msajjadyousaf1988@gmail.com

${ }^{2}$ Department of Botany, Government College University, Faisalabad, Pakistan e-mail: nomi4442003@yahoo.com

${ }^{3}$ Department of Chemistry, Federal Urdu University of Arts, Science and Technology, Gulshan-e-lqbal, Karachi, Pakistan e-mail: atya007chem@gmail.com

${ }^{4}$ Department of Chemistry, Division of Science \&Technology, University of Education Lahore, Pakistan e-mail: qayyumkh12@yahoo.com

${ }^{5}$ Department of Biochemistry, Government College University, Faisalabad, Pakistan e-mail: 234abdullah@gmail.com

Corresponding author:

\section{SHUMAILA KIRAN}

e-mail: shumaila.asimch@gmail.com 


\title{
Assessment of financial and investment activity of textile enterprises as a guarantee of successful business in the region
}

\author{
DOI: 10.35530/IT.071.03.1687
}

YULIIA MELNYCHUK

IRYNA TKACHUK

MAKSYM SLATVINSKYI

OKSANA VINNYTSKA

LIUDMYLA CHVERTKO

TETIANA KORNIIENKO

\section{ABSTRACT - REZUMAT}

\section{Assessment of financial and investment activity of textile enterprises as a guarantee of successful business in the region}

This article is devoted to the research of the interaction of theoretical and methodical bases of using analysis in the process of case management at textile enterprises. The purpose of the study is to prove the necessity of conducting an assessment of the financial status and investment activity of textile enterprises. According to the results of the research, it has been proved that the financial evaluation of the state of financial and investment activity is important in the organization of textile business. The indicators of accounting are the basis for such an analysis and assessment of the financial condition of textile companies. The research has carried out the classification of financial reporting indicators for assessing the activity of the textile enterprise. The elements of financial reporting and their characteristics are analysed. The sources of income generation and expenses of the textile manufacturing company were systematized and revealed. A plan for assessing the effectiveness of activities has been developed and proposed, which will reflect the results of the activity of the textile enterprise. The components of financial reporting are proposed and their purpose is analysed. The conclusions regarding the effectiveness of the evaluation of financial-investment activity of textile enterprises, which influences the results of successful business in the region, are presented.

Keywords: financial analysis, reporting, performance indicators, performance

\section{Evaluarea activității financiare și investiționale a întreprinderilor textile ca garanție a afacerilor de succes} în regiune

Articolul este dedicat cercetării interacțiunii dintre bazele teoretice și metodice ale utilizării analizei în managementul întreprinderilor textile. Obiectivul studiului este de a demonstra necesitatea efectuării unei evaluări a activității financiare și investiționale în întreprinderilor textile. Conform rezultatelor cercetării, s-a dovedit că evaluarea activității financiare și investiționale este importantă în organizarea afacerilor textile. Indicatorii contabili stau la baza analizei și evaluării stării financiare a întreprinderilor textile. Studiul a cuprins clasificarea indicatorilor de raportare financiară pentru evaluarea activității întreprinderii textile. Au fost analizate elementele raportării financiare și caracteristicile acestora. Sursele de generare a veniturilor și cheltuielile întrerpinderilor textile au fost sistematizate și prezentate. A fost elaborat și propus un plan de evaluare a eficienței activităților, care va reflecta rezultatele activității întreprinderilor textile. Au fost propuse componentele raportării financiare, iar scopul acestora a fost analizat. Au fost prezentate concluziile privind eficiența evaluării activității financiar-investiționale a întreprinderilor textile, care influențează rezultatele afacerilor de succes din regiune.

Cuvinte-cheie: analiză financiară, raportare, indicatori de performanță, performanță

\section{INTRODUCTION}

The assessment of the financial and investment activity of textile enterprises is a particularly topical issue in the modern textile industry. Companies that pay significant attention to business administration and business analysis have great opportunities for operating data and making important managerial decisions, including finding investors and sponsors to expand production and sales trends of the textile industry.

The successful operation of a textile enterprise in modern conditions requires an increase in the efficiency of financial and economic activity on the basis of financial analysis. It is based on reliable information reflected in the forms of financial statements. It is the financial statements that should provide complete, unbiased and reliable information about the current state and results of the operation of the company, but the indicators presented in the reports are not enough to make sound and correct management decisions. Conducting an assessment of the financial condition of the company is mandatory at modern textile manufacturing enterprises if they are to profit. Such analysis will allow to timely identify the actual indicators of liquidity, solvency, financial stability, financial attractiveness, profitability, break-even and other indicators, and respond to their changes. And in general, increase the likelihood of adopting sound, constructive and correct decisions, obtaining proposals from investors and sponsors. 


\section{REVIEW OF LITERATURE}

The questions of the analysis and evaluation of the activity of textile enterprises are carried out by foreign and domestic scientists, such as: Melnychuk Y., Berling J., Dominic-Ferreira S., Vuuren V., Justin A., Shaukhin T., Reznichenko K., Samofat I., Podolyak G., Larsson M., Lennborg M., Dubin M., Zadorozhny S., Ishchenko A., Yaremenko N., Tkachenko A., Shmatko K. At the same time, the issue of the need for an analysis of the activity of textile enterprises requires further research. Therefore, the purpose of the article is to determine the peculiarities of analysing the financial and investment situation in a textile company.

Scientists are keen to improve the system for evaluating and analysing the activities of textile companies, as this is a very topical issue today. Thus, the proposed blocks of investment potential and investment activity indices at the national, corporate and household levels for investment activity assessment. Such system of indices reflects the state of investment processes at all stages of investment movement [1]. However, investment processes should be considered in the context of financial activities in general. Investments are an integral part of the financial activity of the textile enterprise.

Human advices are useful, but they can be subjective. We are interested in the opinion of really experienced specialists on this issue. Auditors and financiers, accountants and other specialists know that the reliability of the project is determined not by words but by calculating a number of indicators of the reliability of the investment object, for example, the ratio of own and borrowed funds to the project, liquidity of assets, expected profit, probability of bankruptcy of the company, etc. There are dozens of such indicators, so it is needed to have access to information and have experience in financial and analytical work for their calculation [2]. One has to agree with this opinion, adding to the previous that the results of the assessment of the financial state of the textile enterprise affect the decision of investors. Therefore, the definition of the final financial performance of the company has a great scientific and practical significance. With their help you cannot only evaluate the company's efficiency, analyse its various structural units and activities, but also determine the development strategy, develop a forecast and action plan for the future, establish the results of using the resources spent, in particular, means of production, labour, information [3].

\section{ANALYSIS AND DISCUSSION}

The disclosure of the results of the textile company's activities, in particular, the financial support indicators, plays an important role in making decisions of the investor regarding the choice of the project and is advertising for the company itself. Such indicators are: the level of authorized capital, the level of equity, income and expenses of the company, assets of the company. All these indicators in the complex reflect the financial support of the company and its position in the textile market. However, they do not reflect the assessment of the financial condition, which is only possible, based on the analysis of financial statements.

It is generally known that financial statements are statements that contain information about the financial position, results of operations and cash flows of the enterprise during the reporting period, the purpose of which is to provide users with complete, truthful and unbiased information about the financial position, performance and operating costs of the enterprise for decision-making.

The composition of financial statements is determined by the national accounting (accounting) standards.

Balance sheet - statement of financial position of an enterprise that reflects on a certain date its assets, liabilities and equity.

Report on financial results - a report on income, expenses and financial results of the enterprise.

Cash flow statement - a statement that shows the cash flows and cash flows from the activities of the enterprise in the reporting period.

Statement of equity - a statement that reflects changes in the equity of the enterprise during the reporting period.

Notes to the financial statements are a set of indicators and explanations that provide detailed and substantiated items of the financial statements, as well as other information, disclosure of which is provided by the relevant provisions (standards).

The financial statements of textile enterprises should contain a set of components that will be used in the analysis of its financial condition (table 1).

The assessment of the effectiveness of companies in textile production is based on financial statements in the directions [2]:

- Analysis of the company's income;

- Cost analysis of the company;

- Comprehensive assessment of the financial situation of the textile enterprise: liquidity and solvency of the company, financial stability of the textile enterprise, financial attractiveness, profitability and calculation of the probability of a bankruptcy of a textile enterprise.

The assessment of the effectiveness of a textile company should be determined by the set of indicators already mentioned above. The combination of company profits and expenses with the balance sheet data in terms of financial ratios and indicators reflects the results of the activities of the manufacturer, its financial stability and solvency.

By "costs" we mean any means, money, values, etc., used in the process of doing anything. And "income" reflects the material values, the money received by the company as a result of any activity.

Indicators that reflect the financial content of the profits received at the textile manufacturing enterprises are as follows: structural analysis of company profits and a comparative analysis of profits over a number of years. 


\begin{tabular}{|c|c|c|}
\hline \multicolumn{3}{|c|}{ COMPONENTS OF FINANCIAL REPORTING AND THEIR PURPOSE } \\
\hline $\begin{array}{c}\text { Components } \\
\text { of financial statements }\end{array}$ & Content & Use of information \\
\hline Balance sheet & $\begin{array}{l}\text { Availability of economic resources, which are } \\
\text { controlled by the enterprise, at the balance } \\
\text { sheet date }\end{array}$ & $\begin{array}{l}\text { Estimation of the structure of enterprise } \\
\text { resources, their liquidity and solvency of the } \\
\text { enterprise, forecasting of future loan needs, } \\
\text { estimation and forecasting of changes in eco- } \\
\text { nomic resources that the company is likely to } \\
\text { control in the future }\end{array}$ \\
\hline $\begin{array}{l}\text { Report on financial } \\
\text { results }\end{array}$ & $\begin{array}{l}\text { Revenues, expenses and financial results of } \\
\text { the enterprise for the reporting period }\end{array}$ & $\begin{array}{l}\text { Estimation and forecast: Profitability of the } \\
\text { enterprise, income and expenditure structure }\end{array}$ \\
\hline Cash flow statement & $\begin{array}{l}\text { Changes in the equity of the enterprise during } \\
\text { the reporting period }\end{array}$ & Estimation and forecast of changes in equity \\
\hline Statement of equity & $\begin{array}{l}\text { Generation and use of cash during the report- } \\
\text { ing period }\end{array}$ & $\begin{array}{l}\text { Estimation and forecast of operating, invest- } \\
\text { ment and financial activity of the enterprise }\end{array}$ \\
\hline $\begin{array}{l}\text { Notes to the financial } \\
\text { statements }\end{array}$ & $\begin{array}{l}\text { Selected accounting policies, information is } \\
\text { not provided directly in the financial state- } \\
\text { ments, but required by the Standards of } \\
\text { Accounting, additional analysis of the articles } \\
\text { of reporting necessary to ensure its compre- } \\
\text { hensibility. }\end{array}$ & $\begin{array}{l}\text { Estimation and Forecast: accounting policies, } \\
\text { risks or uncertainties affecting the company, } \\
\text { its resources and liabilities, activities of busi- } \\
\text { ness units, etc. }\end{array}$ \\
\hline
\end{tabular}

Along with incomes, they analyze costs that are high in textile production. Indicators that reflect the financial nature of company expenses are as follows: structural analysis of company expenses and a comparative analysis of costs over a number of years.

Necessary for obtaining a certain result (effect) all expenses are divided into current (daily) and onetime. Current (everyday) expenses include labour costs for different categories of personnel (labour) and the amount of continuously used means of production (the cost of labour, the amount of depreciation), as well as some other costs included in the full cost of production. One-time costs are advanced funds for the reproduction of means of production in the form of capital investments. At the same time, capital investments produce returns (effect, result) only after a certain time equal to the duration of the reproductive cycle of labour and is taken into account when determining their effectiveness. The expenses of the company have their own specifics, which depends on the direction of production.

For textile producers, it is important to control the production process not only in terms of quality, but also in financial indicators that reflect the efficiency of production. The system of indicators of production efficiency is given in table 2 [4-6].

Wages are the main source of living for employees, accounting most of the revenues achieved and

\begin{tabular}{|c|c|c|c|}
\hline \multicolumn{4}{|c|}{ SYSTEM OF INDICATORS OF PRODUCTION EFFICIENCY } \\
\hline \multirow{2}{*}{$\begin{array}{l}\text { Summarizing } \\
\text { indicators }\end{array}$} & \multicolumn{3}{|c|}{ Performance metric } \\
\hline & labour (personnel) & production funds & financial resources \\
\hline $\begin{array}{l}\text { production per unit cost } \\
\text { of resources }\end{array}$ & $\begin{array}{l}\text { growth rate of labour } \\
\text { productivity }\end{array}$ & $\begin{array}{l}\text { total fund of return (by } \\
\text { volume of production) }\end{array}$ & turnover of working capital \\
\hline $\begin{array}{l}\text { profit per unit of total } \\
\text { expenses }\end{array}$ & \begin{tabular}{|c|} 
share of product growth at \\
the expense of productivity \\
growth
\end{tabular} & $\begin{array}{c}\text { fund of return of the active } \\
\text { part of fixed assets }\end{array}$ & profitability of working capital \\
\hline profitability of production & $\begin{array}{l}\text { relative release of } \\
\text { employees }\end{array}$ & profitability of fixed assets & relative release of working capital \\
\hline $\begin{array}{l}\text { costs per unit of } \\
\text { commodity products }\end{array}$ & $\begin{array}{l}\text { coefficient of utilization of } \\
\text { useful working time fund }\end{array}$ & $\begin{array}{l}\text { funds capacity of a } \\
\text { product unit }\end{array}$ & $\begin{array}{l}\text { specific capital investments (per } \\
\text { unit of capacity increase or output) }\end{array}$ \\
\hline $\begin{array}{l}\text { share of product growth } \\
\text { at the expense of inten- } \\
\text { sification of production }\end{array}$ & $\begin{array}{l}\text { labour capacity of the } \\
\text { product unit }\end{array}$ & $\begin{array}{l}\text { material capacity of the } \\
\text { product unit }\end{array}$ & profitability of capital investments \\
\hline $\begin{array}{l}\text { the economic effect } \\
\text { of the use of one product }\end{array}$ & $\begin{array}{l}\text { salary capacity of the } \\
\text { product unit }\end{array}$ & $\begin{array}{c}\text { coefficient of use of the } \\
\text { most important types of raw } \\
\text { materials and materials. }\end{array}$ & $\begin{array}{c}\text { payback period of capital } \\
\text { investments }\end{array}$ \\
\hline
\end{tabular}


having a decisive effect on the standard of living of the employee and its family. Labour productivity is one of the indicators that show how effective the work forces. Of all the factors of production, human capital (meaning labour) is one of the most important factors that impose effects on productivity. Increasing labour productivity means that a larger quantity of goods has been produced over a period of time in a sector or across one country [7].

The problem of improving the efficiency of production is to provide the maximum possible result for each unit spent labour, material, financial and other resources, therefore the criterion of production efficiency in the macroeconomic scale is the growth of productivity of social labour.

The next stage of the analysis is an assessment of the financial state of the textile company by means of indicators that reflect:

- Liquidity of the company:

- coefficient of general liquidity;

- ratio of current liquidity;

- absolute liquidity ratio.

- Financial stability:

- coefficient of concentration of equity capital;

- coefficient of concentration of debt capital;

- correlation coefficient;

- coefficient of financial dependence;

- coefficient of maneuverability of own capital.

- Profitability;

- Probability of bankruptcy.

In general, all measures to improve the functioning of textile enterprises can be reduced to three areas:

- management of expenses and resources of enterprises with textile profile;
- development and improvement of textile production and other activities;

- improvement of the enterprise management system and all types of its activities on the basis of evaluation of the financial and investment situation of the textile enterprise.

As you can see, all measures to improve the efficiency of the textile enterprise are interdependent. However, the most important factors are identified by the third group (direction), because their mobilization involves determining the place of implementation in the management system of activities.

Specialists know that the financial soundness of textile enterprises is determined by calculating a number of indicators: the ratio of own and attracted capital, liquid assets and short-term receivables, and others, for such calculation, indicators of financial reporting are required. In many developed countries, the calculation of indicators is carried out by rating agencies, but each company may have its own financial specialist, which will be engaged in assessing the financial condition of the enterprise.

It should be noted that the modern Ukrainian clothing market is represented by virtually all types of products: from world-famous brands related to fashion houses to unregistered producers. According to statistics, about 6,000 ready-made garments and fur companies are registered in Ukraine. Indicators of activity of enterprises of light industry (including clothing manufacturers) of Ukraine for 2013-2018 are given in the table $3[2,6]$.

The results of the analysis showed that most clothing enterprises operate at a loss, the rest - low-income enterprises. At enterprises of clothing manufacturers

\begin{tabular}{|c|c|c|c|c|c|c|c|}
\hline \multicolumn{8}{|c|}{$\begin{array}{l}\text { INDICATORS OF ACTIVITY OF LIGHT INDUSTRY ENTERPRISES (IN PARTICULAR, CLOTHING } \\
\text { PRODUCERS) OF UKRAINE FOR 2013-2018 }\end{array}$} \\
\hline \multicolumn{2}{|c|}{ Indicators of activity } & 2013 & 2014 & 2015 & 2016 & 2017 & 2018 \\
\hline \multicolumn{2}{|c|}{$\begin{array}{l}\text { Sales volumes, } \% \text { to the total volume of industrial } \\
\text { products }\end{array}$} & 1.1 & 1.1 & 1.0 & 0.9 & 0.9 & 0.8 \\
\hline \multicolumn{2}{|c|}{ Profitability of operating activities of enterprises (\%) } & -0.2 & -0.2 & 0.7 & -1.6 & 3.4 & 2.5 \\
\hline \multicolumn{2}{|c|}{ Operating expenses, mln, $\mathrm{UAH}^{*}$} & 3753.8 & 4285.5 & 4893.5 & 6113.3 & 5093.2 & 5922.4 \\
\hline \multirow{5}{*}{$\begin{array}{l}\text { Operating expenses } \\
\text { structure }(\%)^{*}\end{array}$} & material expenses & 51.6 & 53.4 & 52.7 & 52.9 & 51.0 & 55.1 \\
\hline & salary expenses & 4.9 & 4.6 & 4.6 & 4.0 & 5.0 & 4.3 \\
\hline & deductions for social events & 24.3 & 23.6 & 23.4 & 22.2 & 22.5 & 21.8 \\
\hline & amortization & 8.7 & 8.3 & 8.2 & 7.6 & 7.9 & 7.6 \\
\hline & other operating expenses & 10.5 & 10.1 & 11.1 & 13.3 & 13.6 & 11.2 \\
\hline \multicolumn{2}{|c|}{ Operating expense $1 \mathrm{UAH}$. sold products, UAH* } & 103.3 & 102.3 & 99.0 & 108.1 & 96.1 & 98.5 \\
\hline \multicolumn{2}{|c|}{ Investments in fixed capital, UAH million* } & 344 & 290 & 348 & 365 & 196 & 338 \\
\hline \multicolumn{2}{|l|}{$\begin{array}{l}\text { FDI: } \\
\quad \text { - million dollars } \\
\quad-\% \text { of total inves }\end{array}$} & $\begin{array}{c}129.1 \\
0.8\end{array}$ & $\begin{array}{c}126.6 \\
0.6\end{array}$ & $\begin{array}{c}144.4 \\
0.5\end{array}$ & $\begin{array}{c}139.7 \\
0.4\end{array}$ & $\begin{array}{c}145.5 \\
0.4\end{array}$ & $\begin{array}{c}139.3 \\
0.3\end{array}$ \\
\hline
\end{tabular}

Note: * Information is given on textile manufacturing, clothing, fur and fur products (without leather production, leather goods and other materials). 
operating costs of $1 \mathrm{UAH}$ sold products amounted to $0.96 \mathrm{UAH}$ - in 2017, and $0.98 \mathrm{UAH}$ - in 2018, sewing production of material resources. According to 2018, $55.1 \%$ of operating expenses were material costs, $4.3 \%$ - depreciation, $21.8 \%$ - labor costs, 7.6 deductions for social activities and $11.2 \%$ - other operating expenses. An in-depth financial analysis will contribute not only to enterprise management, but also to ensure the achievement of the goals of economic development of the region of the whole financial system [7].

\section{CONCLUSIONS}

For the more effective development of the garment industry, it is expedient to consider the following measures:

- ensuring the stability of economic, tax and customs legislation, which will facilitate investment attraction;

- more stringent controls during the import of sewing products to prevent smuggling;

- introduction of technical barriers to the import of second-hand, in particular sanitary-hygienic findings;

- directing the activities of enterprises to improve the quality of products and expand the range in accordance with market requirements;

- reduction of the share of production under the toll scheme due to production of the corresponding quality on the domestic market;

- promoting the certification of clothing industry enterprises in accordance with international standards.

The generalization of scientific approaches to assessing the financial and investment status of an enterprise enables us to determine the efficiency of the enterprise on various grounds. At the same time, each type of efficiency provides a separate characteristic of the effectiveness of the textile enterprise, so it is worth paying attention to all types of efficiency, because in the complex, they can significantly improve the final assessment of the enterprise. In our opinion, the assessment of the operation of an enterprise should be determined not by one but by several important criteria. Moreover, when it comes to assessing the activities of enterprises in a particular industry, in particular, textile.

Thus, the assessment of the financial and investment situation of the enterprise is of great scientific and practical importance. It helps you not only to evaluate the efficiency of the company, analyse the overall effect of its various structural units and activities, but also to determine the strategy of development, to develop a forecast and plan of action for the future, to establish the results of the use of resources spent, in particular, the means of production, labour, information. Financial evaluation of the enterprise is a complex feature of the existence of the socio-economic system. It is also necessary to use a complex approach to its definition, which includes a set of criteria for assessing the effectiveness of the enterprise, namely its cost effectiveness, target performance and competitiveness. It is the need for detailed analysis, comparison, the definition of a number of indicators that characterize the financial position of the company, led to the emergence of rating agencies that group the performance of companies and determine the level of its stability. However, an internal analysis of the effectiveness of textile companies provides improved management decision making, which is not possible without the use of accounting information.

Future areas of research can be the development of ways to expand information content, deepening the financial analysis of textile enterprises, forms of financial reporting through its convergence with other types of reporting (creation of integrated reporting) in order to perceive and interpret its indicators to improve the efficiency of management decisions.

\section{REFERENCES}

[1] Ponomarenko, T., Prokopenko, O., Slatvinskyi, M., Biloshkurska, N., Biloshkurskyi, M., Omelyanenko, V., National Investment and Innovation Security Assessment Methodology, In: International Journal of Mechanical Engineering and Technology, 2019, 10, 2, 847-857

[2] Shkolenko, O., Gumeniuk, A., Melnychuk, Y., Melnik, V., Bank deposit as a direction of investment activity's activation of insurers in life insurance, In: Financial and credit activity: problems of theory and practice, 2018, 4, 27, 41-48

[3] Korbutia, A., Sokrovolska, N., Analysis of the efficiency of the textile industry enterprises in Ukraine, In: Money, finance and credit, 2018, 19, 1034-1039

[4] Yakymchuk, T., Socio-economic efficiency of the enterprise and its importance in modern conditions, In: Bulletin of the Zhytomyr State Technological University. Series: Economics, Management and Administration, 2011, 2, 56, 184-189

[5] Rat, O., Determination of the essence of the concept of "the efficiency of the operation of the enterprise", In: Economic Space, 2008, 15, 275-285

[6] Korbutyak, A.G., Sokrovolskaya, N., Features of planning the level of profitability of domestic enterprises in modern conditions, In: Scientific herald of Uzhgorod National University, 2017, 16, 1, 153-157

[7] Melnychuk, Y., Chyrva, O.H., Chvertko, L.A., Chyrva, H.M., Berbets, V.V., The Role of Management in the Financial Independence of the Region, In: TEM Journal, 2019, 8, 2, 584-590 
Authors:

YULIIA MELNYCHUK¹, IRYNA TKACHUK², LIUDMYLA CHVERTKO ${ }^{1}$, MAKSYM SLATVINSKYI ${ }^{1}$, OKSANA VINNYTSKA ${ }^{1}$, TETIANA KORNIIENKO ${ }^{1}$

${ }^{1}$ Pavlo Tychyna Uman State Pedagogical University, Educational and Scientific Institute of Economics and Business Education, Department of Finance, Accounting and Economic Security,

Sadova street, no. 2, 20300, Uman, Ukraine

e-mail: luda_um@ukr.net, slat.maks@gmail.com, vinnytska.oksana@ukr.net, kornienkoto@ukr.net

${ }^{2}$ Vasyl Stefanyk Precarpathian National University, Faculty of Economics, Department of Finance,

Shevchenko street, no. 57, 76018, Ivano-Frankivsk, Ukraine

e-mail: kfin@pu.if.ua

Corresponding author:

YULIIA MELNYCHUK

e-mail: melnichyk_yuliya@ukr.net 


\section{Creators of competitiveness in the textile and clothing industry from the Hidalgo state}

DOI: 10.35530/IT.071.03.1705

\section{ABSTRACT - REZUMAT}

\section{Creators of competitiveness in the textile and clothing industry from the Hidalgo state}

Nowadays, technological innovation is a very important agent not only in the business sector, but also in the research sector, especially when it is related to factors such as competitiveness, since it is perceived as a determinant for the future of the industry and business development. This research presents the development of the work "Generalities of the textile industry and its relevance in the business competitiveness of medium-sized companies in the state of Hidalgo" in which the competitiveness of some Hidalgo organizations in the industrial sector is analysed based on innovation in technology. The work consists of a theoretical review and the application of instruments to medium-sized companies in the industrial sector, considering the database of the Mexican Business Information System (SIEM). Based on the above, an instrument was created that allows knowing if the competitiveness in the industries depends on the technology implemented in these organizations. The work was carried out in two stages: in principle, a brief theoretical framework is developed in which the importance of innovation in technology for the competitiveness of companies in the textile industry is explained and, subsequently, the way is opened to the Field research, where this relationship is analysed for the particular case of medium-sized Hidalgo companies. It should be noted that these are the partial results derived from the creation of the measurement instrument and the application of a pilot test to these companies.

Keywords: technology, innovation, company, industrial sector, production

\section{Creatorii de competitivitate în industria textilă și de îmbrăcăminte din statul Hidalgo}

În zilele noastre, inovarea tehnologică este un agent foarte important nu numai în sectorul de afaceri, ci și în domeniul cercetării, mai ales atunci când este legată de factori precum competitivitatea, deoarece este percepută ca un factor determinant pentru viitorul industriei și al dezvoltării afacerilor. Această lucrare prezintă rezultatele cercetării „Generalități ale industriei textile și relevanța acesteia în competitivitatea în afaceri a companiilor mijlocii din statul Hidalgo", în care este analizată competitivitatea unor organizații din Hidalgo, în sectorul industrial pe baza inovării tehnologice. Lucrarea constă într-o documentare teoretică și aplicarea instrumentelor în companii mijlocii din sectorul industrial, utilizând baza de date a Sistemului de informații despre afacerile din Mexic (SIEM). Pe baza celor de mai sus, a fost creat un instrument care permite evaluarea competitivității din industrii în funcție de tehnologia implementată în aceste organizații. Lucrarea a fost realizată în două etape: inițial, este elaborat un cadru teoretic în care este explicată importanța inovării tehnologice pentru competitivitatea companiilor din industria textilă și, ulterior, se deschide calea către cercetarea pe teren, unde această relație este analizată pentru cazul particular al companiilor mijlocii din Hidalgo. Se menționează că acestea sunt rezultatele parțiale care provin din crearea instrumentului de măsurare și din aplicarea unui test pilot pentru aceste companii.

Cuvinte-cheie: tehnologie, inovare, companie, sector industrial, producție

\section{INTRODUCTION}

The present investigation belongs to the activities developed by the academic body Management and Business Development of the Institute of EconomicAdministrative Sciences (ICEA) of the Autonomous University of the State of Hidalgo (UAEH), and whose objective was to analyse the impact of technological innovation in medium-sized companies in the industrial sector within the State of Hidalgo.

The theoretical evidence highlights the need to know the factors that affect the achievement of high levels of competitiveness by organizations, factors that seem to be oriented towards innovation and optimal application of technologies in production processes [1].

\section{GENERAL INFORMATION}

The textile industry constitutes a significant sector for the economy of many countries due to its participation in the GDP and the generation of jobs [2]. In the case of Mexico, with the implementation of the North American Free Trade Agreement (NAFTA) it represented attraction of foreign investment, development of strategic alliances and access to technology, which, finally, would result in growth of the economy. However, there have been several phenomena that have negatively affected the dynamics of trade between the United States and Mexico [3].

The socioeconomic contribution of this sector was reflected in the creation of jobs, since the number of workers in the textile sector went from 42,231 in 1990 


\begin{tabular}{|l|c|c|c|c|c|c|}
\hline \multicolumn{7}{|c|}{ ELEMENTS OF THE PILOT TEST COMPANIES (N = 10) } \\
\hline Levels & Age & $\begin{array}{c}\text { Percentage of } \\
\text { foreign capital } \\
(\%)\end{array}$ & $\begin{array}{c}\text { Export } \\
\text { percentage } \\
(\%)\end{array}$ & $\begin{array}{c}\text { Number of } \\
\text { workers }\end{array}$ & Sales (\$) & $\begin{array}{c}\text { Number of patents, } \\
\text { prototypes and } \\
\text { copyrights }\end{array}$ \\
\hline Median & 18 & 5.9 & 6.3 & 275 & $77,757,140.50$ & 12 \\
\hline Total pilot test & 18 & 5.9 & 6.3 & 275 & $77,757,140.50$ & 12 \\
\hline
\end{tabular}

\section{Table 2}

\begin{tabular}{|l|c|c|c|c|c|c|c|c|}
\hline \multicolumn{7}{|c|}{ ELEMENTS OF THE COMPANIES INTERVIEWED (N = 10) } \\
\hline \multirow{2}{*}{$\begin{array}{l}\text { Dimension of } \\
\text { the company }\end{array}$} & Turn: sector 313 & \multicolumn{2}{c|}{ Turn: sector 314 } & \multicolumn{2}{|c|}{ Turn: sector 315 } & \multicolumn{2}{c|}{ Turn: sector 316 } \\
\cline { 2 - 9 } & Number & $\begin{array}{c}\text { Percentage } \\
(\%)\end{array}$ & Number & $\begin{array}{c}\text { Percentage } \\
(\%)\end{array}$ & Number & $\begin{array}{c}\text { Percentage } \\
(\%)\end{array}$ & Number & $\begin{array}{c}\text { Percentage } \\
(\%)\end{array}$ \\
\hline Median & 3 & 30 & 3 & 30 & 2 & 20 & 2 & 20 \\
\hline Total pilot test & 3 & 100 & 3 & 100 & 2 & 100 & 2 & 100 \\
\hline
\end{tabular}

to 26,559 ten years later [4]. However, this trend weakened as globalization favoured the pressure to increase competitiveness in terms of quality, productivity and flexibility from the shift of production activities to countries with the capacity to offer costs low labour costs [3].

On the other hand, in Mexico, the contribution of the textile and clothing sector to international trade reached the export leadership in the period between 1990 and 2002 when achieving a participation in the imports of EE. UU of $11.58 \%$, but the lack of technological innovation caused the loss of competitiveness against Asian and Eastern European countries at the beginning of the first decade of the $21^{\text {st }}$ century, mainly because labour costs no longer represent a competitive advantage, because those from countries such as China and India are even lower [4].

From an organizational approach, technology is conceived as the use of knowledge for the creation of goods and services, which make it one of the main mechanisms available to design, create and distribute their products [5].

The term technology is used to refer to the process by means of which tools are developed that elevate the control and understanding of the material context, this construct is made up of two kinds of knowledge: the codified and the tacit. Additionally, technologies are affecting the economic environment and, along with them, the needs of consumers, which are increasingly difficult to satisfy, which implies a challenge for companies to implement new strategies that allow them to be more competitive. Contemporary fashion trends and modern technologies impose more requirements to the textile industry.

The innovation is one of the most important factors for the so called "Knowledge Society", in which knowledge constitutes, precisely, a strategic element for all nations and organizations, where the correct management of it, represents improvements in com- petitiveness and survival within a globalized economy [6].

In the degree to which knowledge is oriented towards producing innovations, in that degree a greater development in technology will be achieved. The Economic Commission for Latin America and the Caribbean (ECLAC) highlights that among the main factors that distinguish the current economy are the following [7]:

- mostly codified knowledge;

- science and technology in close relationship, high innovation rates and a short product life cycle;

- greater relevance in continuous learning, in education and in the issue of innovation in GDP growth;

- lower investment in fixed capital and more in intangible factors (R\&D, education, software);

- labour market and its variability in demand.

Tables 1 and 2 show the results obtained from the application of the pilot test to the 10 medium-sized companies in the textile and clothing sector.

Table 3 shows the percentage of variance $\left(R^{2}=0.37\right.$, $p<0.01)$ finding a statistically significant relationship between the variables "characteristics of companies in exports" $(\beta=0.42 ; p<0.01)$ and "infrastructure" (specifically in the dimension "renewal and expansion of products and services"). According to these results, renewal and expansion of the range of products is generated based on the presence of an export performance of medium-sized companies, so that medium-sized companies in the state of Hidalgo are competitive in their exports require the best infrastructure in their productive processes.

For its part, the results presented in table 4 show that there is a statistically significant relationship between the number of patents and utility models of companies and the variable "human capital formation", which indicates that innovation for the development of patents, utility models or copyright of companies $(\beta=-0.50 ; p<0.01)$ resides, to a large extent, in the 


\begin{tabular}{|c|c|c|c|c|}
\hline \multicolumn{5}{|c|}{$\begin{array}{l}\text { RESULTS OF THE HIERARCHICAL REGRESSION ANALYSIS OF THE PILOT TEST } \\
\text { (INFRASTRUCTURE/RENEWAL AND INCREASE OF THE VARIABILITY OF PRODUCTS AND SERVICES) }\end{array}$} \\
\hline Variable: Elements of the company & Step 1 & Step 2 & Step 3 & Step 4 \\
\hline Age & -0.05 & 0.08 & 0.05 & 0.05 \\
\hline Percentage of foreign capital & 0.05 & -0.07 & -0.07 & -0.09 \\
\hline Export percentage & - & $0.53^{* *}$ & $0.40^{* *}$ & $0.42^{* *}$ \\
\hline Sales & - & - & -0.03 & -0.02 \\
\hline Number of patents, prototypes and copyrights & - & - & - & 0.14 \\
\hline $\mathrm{R}$ & 0.09 & $0.30^{* *}$ & $0.30^{* *}$ & $0.32^{* *}$ \\
\hline $\mathrm{R}^{2}$ & 0.01 & $0.25^{* *}$ & $0.25^{* *}$ & $0.37^{* *}$ \\
\hline $\mathrm{R}^{2}$ Adjusted & 0.03 & 0.21 & 0.19 & 0.20 \\
\hline
\end{tabular}

Note: ${ }^{*} p<0.05$ and ${ }^{* *} p<0.01$

RESULTS OF THE HIERARCHICAL REGRESSION ANALYSIS OF THE PILOT TEST (FORMATION OF HUMAN CAPITAL)

\begin{tabular}{|l|c|c|c|c|}
\hline \multicolumn{1}{|c|}{ Variable: Elements of the company } & Step 1 & Step 2 & Step 3 & Step 4 \\
\hline Age & -0.06 & 0.08 & 0.05 & 0.05 \\
\hline Percentage of foreign capital & 0.06 & -0.07 & -0.07 & -0.09 \\
\hline Export percentage & -0.01 & -0.01 & 0.01 & -0.01 \\
\hline Sales & -0.01 & - & -0.01 & -0.02 \\
\hline Number of patents, prototypes and copyrights & $0.49^{* *}$ & $0.50^{* *}$ & $0.50^{\star *}$ & $0.50^{* *}$ \\
\hline$R$ & 0.20 & $0.25^{* *}$ & $0.55^{\star *}$ & $0.52^{* *}$ \\
\hline$R^{2}$ & 0.01 & $0.35^{* *}$ & $0.35^{* *}$ & $0.38^{* *}$ \\
\hline$R^{2}$ Adjusted & 0.03 & 0.22 & 0.29 & 0.23 \\
\hline
\end{tabular}

Note: ${ }^{*} p<0.05$ and ${ }^{* *} p<0.01$

formation of their human capital, obtaining a percentage of explained variance of $R^{2}=0.38(p<0.01)$

In general terms, both analyses carried out in the pilot show a significant association between the variables innovation in infrastructure and training of human capital and exports and innovations of companies, but not with the age of the company and its sales volume.

\section{CONCLUSIONS}

Technological innovation is a very important factor in the achievement of business competitiveness, which also has an impact on the economic development of any country, since it is a guiding axis in the production of goods and services.

The partial results of this research show interesting aspects to be analysed: in the first instance, the positive relationship between the characteristics of the companies and the infrastructure and innovation in the production processes of these. Similarly the role of investment in intellectual capital and in the generation of knowledge that brings innovation from the creation of brands and patents, key factors in achieving competitiveness.

The objective of this study is to identify the influence of innovation in technology on the competitiveness of medium-sized companies in the textile and clothing sector in the state of Hidalgo, in turn, develop improvement proposals that allow them to be competitive in the regional market, National and international.

\section{ACKNOLEDGEMENTS}

The authors wish to express their gratitude to the companies that collaborated in the study, to the Autonomous University of the State of Hidalgo and to the Institute of Economic and Administrative Sciences, for allowing and supporting research.

\section{REFERENCES}

[1] Giacometti, L., Innovación tecnológica y desarrollo de ventaja competitiva en la atención a la salud: enfoque conceptual y metodológico, In: Revista Gerencia y Políticas de Salud, 2013, 12, 25, 66-82

[2] Ibercondor, La industria textil en México, Available at: https://ibercondor.com/blog/la-industria-textil-mexico/ [Accessed March 28th 2018] 
[3] Saucedo, O., La industria textil en México: TLCAN, China y la globalización. Un análisis a favor de una estrategia de desarrollo integral, Cátedra Levi Strauss-Anáhuac por la libertad de asociación en la industria de la confección, Centro Idearse, Universidad Anáhuac, 2013

[4] Arroyo, M., Cárcamo, M., La evolución histórica e importancia económica del sector textil y del vestido en México, In: Economía y sociedad, 2010, 14, 25, 51-68

[5] Londoño, J., Tecnología como factor de innovación en empresas colombianas, In: Revista venezolana de gerencia, 2015, 20, 70, 201-216

[6] Aponte, G., Gestión de la innovación tecnológica mediante el análisis de la información de patentes, In: Negotium, 2016, 11, 33, 42-68

[7] Ríos, H., Marroquín, J., Innovación tecnológica como mecanismo para impulsar el crecimiento económico, In: Evidencia regional para México. Contaduría y Administración, 2013, 58, 3, 11-37

\section{Authors:}

\section{TIRSO JAVIER HERNÁNDEZ-GRACIA, DANAE DUANA-AVILA}

Autonomous University of the State of Hidalgo, Institute of Economic and Administrative Sciences, Academic Area of Administration, La Concepción circuit, km 2.5, San Juan Tilcuautla Municipality of San Agustín

Tlaxiaca, Hidalgo, 42161, Pachuca Hidalgo, México

e-mail: thernan@uaeh.edu.mx

Corresponding author:

DANAE DUANA-AVILA

e-mail: danae@uaeh.edu.mx 


\section{The challenge of young Romanian designers: creativity in business}

DOI: 10.35530/IT.071.03.1818

DENISA BOGDANA ABRUDAN

MARGARETA STELA FLORESCU

MĂDĂLINA DUMITRIȚA MATICIUC

DANA CODRUȚA DĂIANU

MARIAN NĂSTASE

\section{ABSTRACT - REZUMAT}

The challenge of young Romanian designers: creativity in business

The present paper focuses on the subject of creativity in business starting from a set of interviews with young designers (fashion designers mostly, but not exclusively). In order to provide an updated overview of the "ecosystem" of creativity, we intend to add to the field literature, thus offering a more comprehensive understanding of creativity by focusing on the role of designers in facilitating or inhibiting creativity in business in the fashion industry. The work was limited contextually to the fashion sector in the western region of Romania, with the data being collected through semi-structured interviews with entrepreneur fashion designers (producers of clothing, footwear and accessories). The analysis aims to identify and highlight the attributes of entrepreneur designers in the creative industry, as well as the ways in which they are inclined to develop their creativity in order to combine various materials or textures into something original. The results of our research are in fact empirical evidence regarding the strategic role of entrepreneur designers when it comes to creativity in business, a role that can allow them to achieve durable competitive advantage for their own businesses by developing both the analytical skills necessary for interpreting economic data to validate an idea, and the intuitive skills regarding the economic climate. Although the specific context may be considered a limitation of the study, it may become a real advantage for potential future research that will extend the boundaries of the present one.

Keywords: entrepreneurship, creative industry, fashion design, passion, imagination, competitive advantage

\section{Provocarea tinerilor designeri români: creativitatea în afaceri}

Lucrarea de față se concentrează pe tema creativității în afaceri pornind de la un set de interviuri cu tineri designeri (mai ales designeri de modă, dar nu exclusiv). Pentru a oferi o imagine de ansamblu actualizată a „ecosistemului” creativității, a fost prezentată literatura de specialitate din domeniu, oferind astfel o înțelegere mai cuprinzătoare a creativității, prin concentrarea pe rolul designerilor în facilitarea sau inhibarea creativității în afaceri în industria modei. Cercetarea s-a limitat contextual la sectorul modei din regiunea de vest a României, datele fiind colectate prin interviuri semi-structurate cu designeri de modă antreprenori (producători de îmbrăcăminte, încălțăminte și accesorii). Analiza își propune să identifice și să evidențieze atributele designerilor antreprenori din industria creativă, precum și modalitățile în care sunt înclinați să iși dezvolte creativitatea, pentru a combina diverse materiale sau texturi cu abordări originale. Rezultatele cercetării sunt de fapt dovezi empirice cu privire la rolul strategic al designerilor antreprenori, atunci când discutăm despre creativitatea în afaceri, rol care le poate permite să obțină un avantaj competitiv durabil pentru propriile afaceri, prin dezvoltarea atât a abilităților analitice necesare interpretării informațiilor economice pentru validarea unei idei, cât și a abilităților intuitive cu privire la climatul economic. Deși contextul specific poate fi considerat o limitare a studiului, acesta poate deveni un avantaj real pentru cercetările viitoare, care vor depăși limitele celei prezente și pot valida și în alt context rezultatele obtinute.

Cuvinte-cheie: antreprenoriat, industrie creativă, design vestimentar, pasiune, imaginație, avantaj competitiv

\section{INTRODUCTION}

As companies have become increasingly oriented towards gaining and maintaining competitive advantage by stimulating the creativity of their employees [1] we deem it important to understand how creativity in the entrepreneur designers' workplace can be facilitated or inhibited, by analysing their attributes and the individual manner in which the creative process unfolds.

In the last decades multiple studies have been carried out that have provided information of great importance regarding creativity. However, there is still a significant lack of qualitative research on this topic, the literature showing a predominance for quantitative research. For example, the works of Guilford [2] involved simply counting ideas, with no regard for the qualitative element, i.e. that arbitrariness of ideas. Torrance [3] analysed 388 correlations between intelligence and creativity. These pioneering tests were criticized [4] on the grounds that they were aimed at measuring creative intelligence and not creativity itself, but also because they used preponderantly quantitative analyses. This aspect continued even after the 2000s, when Vincent and his colleagues [5] analysed the correlation between intelligence and 
expertise. Thus, in order to rebalance the literature, we considered it relevant to carry out a qualitative research on the topic of creativity and to channel it into the business environment.

The economic environment has caused companies to focus on creativity. Thus, in order to survive in an environment that is changing at an unpredictable speed [6], organizations must stimulate the creativity of their employees, as their ideas are essential if they are to remain innovative and competitive [7]. Florinda [8] argued that people, through their creative potential, are key elements in adding economic value to their sector of activity.

Moreover, although there are several studies on creativity in business, they focus mainly on critical actors such as managers and employees from large fashion houses or large companies. In this regard, our paper innovates by presenting interviews with designers in charge of their own business, in order to shed light on how they perceive creativity in business. We intended to focus on a qualitative research on creativity in business, on the analysis of the creative process in the fashion industry by conducting interviews with Romanian entrepreneur designers.

\section{LITERATURE REVIEW}

The notion of creativity has a long history, its study appearing to have increased at the beginning of the $20^{\text {th }}$ century, especially in the field of psychology [9-10]. Nowadays, the concept of creativity is associated with the ability to bind unique connections, the emergence of new products [11] or the development of new and distinctive solutions for the existing problems [12].

As organizations face increasingly complex challenges, their ability to adapt and properly manage innovation projects is crucial in order to achieve longterm success and competitiveness [13].

There is ample evidence in favour of regarding the concept of creativity as having relevance in facilitating entrepreneurial success [14], an attribute that ensure the entrepreneurial process and can decisively help in discovering new business opportunities [15]. Entrepreneurship in the creative industries (creative entrepreneurship) is a concept that brings to the fore the combination of several qualities, such as those of being an artist or a creator with that of being a businessman and, in so doing, proves the ability to add value to the economic development, especially where the traditional economy has failed. Creative businesses are considered to be those sectors of creation, which focus on technological development, generate profit and rethink culture as a catalyst for national and regional development, constantly adapting to the needs and requirements of their own clients and of competitive and dynamic markets [16]. Businesses in the creative industries begin their activity on a small scale [17], but show great diversity. For them, creativity was the core of the idea and maybe even the answer to the question: What should companies do to become more innovative, more creative in order to fulfil the dreams, passions and desires of customers? [18].

Entrepreneurship in the fashion design sector requires the entrepreneur to bring together the new design process and business practices [19]. Because the design process is often intuitive and experimental, and business development is generally approached systematically and logically, these two areas require new skills and new ways of thinking, their successful combination being certain to generate new challenges [20]. More and more, the textile industry and the fashion business is connected to what we call green marketing and green business. That means that the entrepreneurs are interested in how the market evolves, how the ecopreneurship develops, how the consumer behaviour is changing and how to deal with the new challenges for sustainability and competitiveness in long run [21-22]. It is proven that when accepted and assumed, business knowledge is a strong point and entrepreneurial designers can use creativity to start and grow their own business [23].

Studies in this field show that an exploratory approach can highlight creativity and innovation, in doing business especially at their beginning [24-25]. In our case, for fashion designers, these types of business vision offer an inspired solution to achieve competitive advantage in a dynamic and complex business world. And, it is to remark that this wind of change, of being more accountable and involved in transforming the organizations in sustainable ways, is felt in all fields of society, going from public administration to private sector and NGO's [26].

The strategy of sustainable development for clothing business is possible to be implemented by integrating the vertical value chain and paying attention to their major components as the creative department, fashion design, but also better marketing and sales approaches. At the same time the creativity and innovation must be understood as key elements for the architecture of the modern business in textile industry, but as well as in all types of activity.

\section{METHODOLOGICAL APPROACH}

In this paper, we aimed to connect creativity and business in that way so that it might give us the insight into the different aspects of creativity in the entrepreneurship for the domain of creative industries. The idea is to raise awareness of the importance of creativity for industry, to gain better understanding of the creativity process, as well as the concrete solutions of creativity and business integrations might be proposed. In order to do that, two main research goals are formulated:

- to see how designers perceive creativity, targeting the questions of (a) how they define creativity,

(b) identification of attribute of creative individuals,

(c) identification of the factors that encourage creativity, (d) creativity process; 
- to consider how creativity helps entrepreneurs in business and how to perceive the link between those two.

In order to understand the complex meanings of creativity, we resorted to a qualitative approach, the data being gathered based on semi-structured interviews over a period of two calendar months. The interviews were conducted by a single researcher, always the same. Out of the 25 entrepreneur designers invited to participate in this research, only 17 responded to the invitation. Participation in the study was done on the basis of anonymity, which is why in the paper the designers are referred to using code names ranging from D1 to D17. Participation in the interviews was done on the principle of "convenience contacts" and, subsequently, using the snowball technique. The criteria for inclusion in the sample included being an entrepreneur from the western region of the country and belonging to a segment of the fashion industry. The geographical distribution targeted the major western cities as well as emerging cities.

Prior to the interviews, the participants were informed of the topic. The average time allocated to an interview was 45-60 minutes. The designers also completed a questionnaire with the help of which we collected a series of demographic data and significant experiences from their lives.

The transcribed interviews were processed using the qualitative analysis software ATLAS.ti. During the first stage, the data were coded for each category of questions in the interview, followed by a recording of the previous sections using codes that resulted from interviews inductively.

For a clearer presentation of the data, the topics discussed were illustrated in the paper with quotes from the interviews.

\section{EMPIRICAL RESULTS}

The transcribed interviews were processed using the qualitative analysis software ATLAS.ti. During the first stage, the data were coded for each category of questions in the interview, followed by a recording of the previous sections using codes that resulted from interviews inductively.

The interpretative analyses of the interviews led to the identification of 17 themes grouped into 4 categories: creativity in fashion design, attributes of creative individuals, the creative process and creativity in business.

As mentioned earlier, respondents were asked to talk about the evolution of their career in the fashion industry, with the interviews including questions regarding how entrepreneur designers define creativity, what the characteristics of creative individuals and the factors that encourage or inhibit creativity are and, business-wise, how creativity is helpful in their activity.

\section{Creativity in fashion design}

Regarding the evolution of their careers, the designers insisted that it was natural and incremental. We note the statements of two of the designers. In retrospect, D5 states about the beginning of his career: "I began modestly, by giving out what I was making. Upon realizing how great the demand was, I decided to put all the products up for sale, and now I only work on demand. I have been very pleased so far". In the same context, D6 gave the following account: "The evolution was organic. It started with the passion of a small child which then turned into a burning call. 10 years ago, I started to take on projects from customers, and 8 years ago I launched my first collection. But everything became orderly and settled five years ago when I started the company and the workshop".

The designers also proposed definitions for creativity, from their own perspective, with D6 and D11 describing the artistic and creative work as the passion of their life. The designers talked about the intrinsic motivation that caused them not to give up in difficult situations, in order to turn their ideas into reality. Thus, D6 mentions: "Creativity is the driving force of my life. I feel it start every day and always push me forward. Creativity is that aspect that helps me innovate, evolve and create a life of which I am proud", while D11 presents creativity through the lens of the different ways of exploring with what you have at hand: "A way of expressing your own style and ideas, uniqueness, innovation... there are certain attributes that some possess and others do not; in my case creativity starts from the materials I have available when I start working on something new. From a «fistful» of beads and crystals, I can make various products, I don't know ... a pair of earrings, a staple, a necklace - I choose the most successful option, on the spur of the moment. But for others it is just a «fistful» of beads and crystals..."

Also related to the definition of creativity was the subject of its origins, more precisely whether it is innate or not, and in this situation two types of answers stood out. The vast majority of respondents (14) correlated this question with the one linked to the definition of creativity and thus advanced the idea that individuals are born with talent that they subsequently develop through creativity, while 3 of the designers considered that anyone can develop their creative potential through learning and repetition.

With respect to the factors that stimulate/inhibit creativity, designers suggested there are numerous experiences that influence their creativity. Exposure to stimulating, challenging environments can increase creativity, as D1 states: "It is possible that a stroll or certain documentaries arouse my creativity... I do not force anything. Everything comes naturally".

Other designers, too, place the emphasis on nature as an incentive. However, the inhibitory factors seem to differ from one designer to another. More exactly: "Nature is always a helpful element. Even stress helps develop creativity. I have found that under stressful conditions, I show creativity. I often work better under pressure". D5 said, while D6 explained: "Natural light, rest and sun help a lot. And creativity is stifled by cold, darkness, stress, anxiety, or health 
factors". On the other hand, for D11, the inhibition of creativity is justified by the intense search: "While I work, I usually come up with the most ideas for future items (...) When I seek inspiration from other fields such as architecture, fashion, photography, etc. I'm completely confused, I can't stop searching and I can't focus on a subject, so too much research inhibits my creativity, I suppose".

The attributes of creative Individuals vs. the attributes of designers

One of the secondary aims of the research was to identify the opinions of the entrepreneur designers in the fashion industry regarding the attributes of creative individuals. The 17 designers constantly mentioned the same four attributes of creative people: imagination (14 designers), followed by originality (11 designers), passion for creation (9 designers) and intuition (8 designers) as can be seen in figure 1 .

Even when they talked about how they define creativity, some of the interview participants used qualities of creative people, mentioning passion almost as often as originality: D17 "For me, creativity means passion, harmony, sensitivity, emotion" or D13: "Freedom of expression, freedom to do what you like, how you like it and when you like it. Flexibility. Enthusiasm. It's actually... Passion".

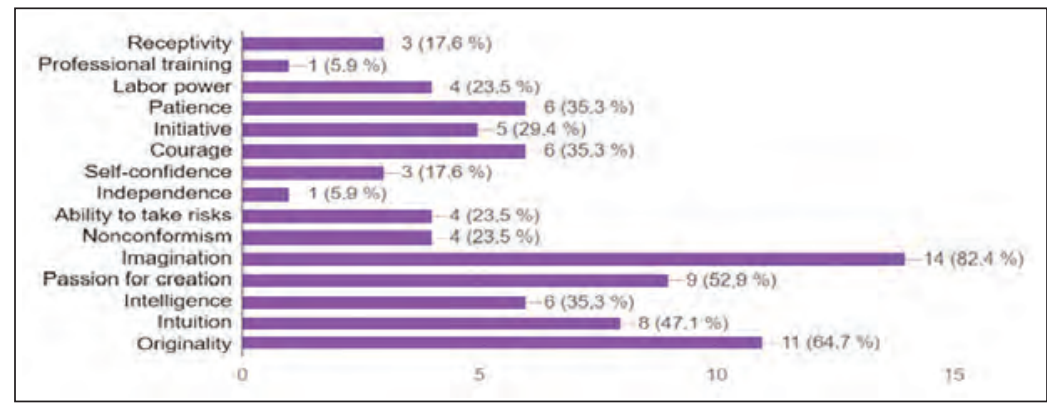

Fig. 1. The attributes of creative individuals
They all noted that the creative process is different from one product to another, from one creator to another, from one moment to another. For instance, D5 mentioned: "I start from the client's wish. He tells me what he wants from me, I ask him what colors and elements he generally wants to find in the final product and from there on everything comes only from my imagination".

It is worth noting that none of the designers has mentioned a perfect template for the creative process. Each of them spoke about diversity and at the same time about specificity. D1 emphasized: "I do not have a pattern of the creative process. It may start with a sketch that undergoes changes along the way, or I can sit at the work bench, simply start working and the ideas might spring to mind at any moment. Often an idea presents itself unexpectedly, so then I write it down, I look for solutions, do some trials, maybe sketch something and when I feel it may lead to something good, I start working".

\section{Creativity in business}

In the next decade, a quarter of all jobs will be completely new. The future is not predictable, but we will have to create it, and that means we will be forced to retrain our mind and adopt an entrepreneurial way of thinking. Companies, big or small, are challenged to adopt new business strategies, to create and develop a creative, innovative business environment. This is also evident from the opinions of the interviewed designers. D1: "There is a point where the two have to meet. A perfect balance must be created between them. Either you have someone to handle the business details, or you have to know when to put an end to the wave of creativity and pay attention to the

When asked which attributes define them as designers, their answers included most often the terms passion, patience and perseverance. Participants noted that being flexible is also a feature of creative people. Moreover, to the question "To what extent have these attributes impacted on your professional performance?" 10 of the designers responded "extensively", and the 7 others "a lot".

\section{The creative process}

The creative process seems to present a multitude of elements common to most interviewees, as D1, D5 and D6 explain. If, in the pre-interview stages, they considered creativity to be innate or developed, the vast majority consider inspiration as an incipient phase, as D6 does: "I start with inspiration, then I do research for that collection/that product. After the research, come the sketches and the materials. The next step is represented by the sketch and the design of the product itself. The trying on and the finish follow." reality and the material side". "You can be creative in any field [...]. Creativity is a business" mentions D11, while D13 looks at the results: "The business is the purpose of the art, the way it reaches the consumer. There is no art if it is not used, if no one sees it, it does not exist".

Also, D14 captures through his words the idea of success where creativity and business meet: "Innovation is always needed to succeed in business, it is very important to be creative, to always create new products that meet the needs of customers. For a company's financial success, creativity is essential". Each of the designers' opinions illustrates how they dispel the tensions and erase the boundaries between artistic creativity and business, as described by D8: "If art/design is based on subjectivity and emotion, then business is the objective and pragmatic part, and without both elements, a business in the creative industries would be pointless". 


\section{DISCUTIONS}

In order to elaborate this study, a number of 17 entrepreneur designers were asked to share their own opinions of creativity based on their own experiences, through semi-structured interviews. In the collected data set, descriptors were identified that refer to creativity, specific to each of the topics discussed. Following the data analysis, we were able to identify the most frequently used terms, revolving around the central ones ("creativity", "creative" and "business"), namely "work", "imagination", "product", "think", by taking into account the central position in the word cloud (figure 2). This actually reflects a very high density of these terms in the idiom of designers. The analysis of the network of keywords used by designers also revealed a particular focus on the following terms: "ideas", "passion" and "originality", especially when the discussions were about the attributes of creative people. When they referred to the creative process, designers quickly moved from "creativity" to "innovation", subsequently linking information about the materials used with terms such as "intuition", "patience" and finally, most of them talked about "results" and "creative solutions".

Based on the topics discussed regarding creativity, we proposed a model to help explain the opinions of the 17 entrepreneur designers from the fashion industry, a model that could contribute to the understanding of creativity in this sector (figure 3).

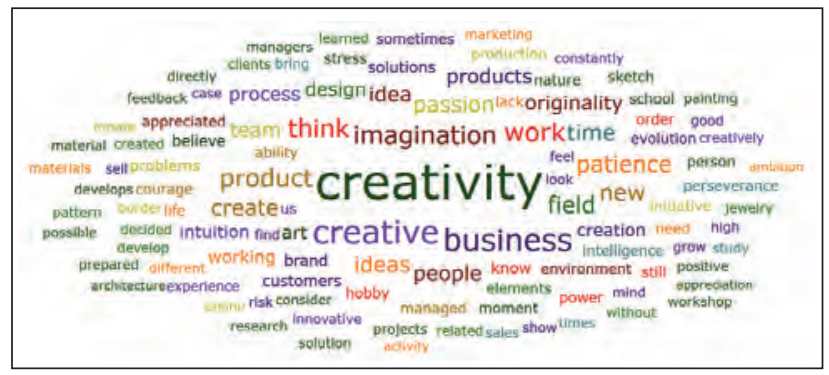

Fig. 2. Word cloud (Interviews processed using ATLAS.ti)
Based on the idea that designers regarded creativity as innate (being associated with the artist's actual activity) or developed (by making the distinction between talent and the ability to solve problems creatively), the creative process can be enriched by strategies meant to stimulate creativity, such as: participation in experience exchanges with other professionals, training/specialization courses and participation in conferences. Therefore, regardless of how they perceive the origin of creativity, and no matter how important it would be to use creativity stimuli (the designers' choices leaning entirely towards great and considerable importance), the participants in the study considered that these serve as a predisposition to the appearance of inspiration (D17: "Sometimes inspiration can be triggered by the sight of a colour, a pattern, or by the feeling of a texture or a fabric."). Whether doing research to advance, or making sketches to highlight the details or, rather, actually choosing the materials, one reaches the stage of making the pattern, a very important element in giving life to the idea. At this point, with the materials and the pattern ready, the cutting process may begin. A product can have several layers, it can be lined or made of different textures. For all these details, patterns must be made, based on which the cutting is done. The parts are then assembled and, before the finish, if the situation requires it, the sample is tried on and any necessary alterations are made so that the product conforms to the original idea. The last stage could be a final trying on or even the final touch.

\section{CONCLUSIONS}

The results show that although, initially, in their reports, designers regard creativity as a particularly important feature for those working in the fashion industry, when referring to the business, the notion of creativity actually appears to be associated with that of performance.

The analysis of the points of view of the entrepreneur designers who are active in the fashion industry

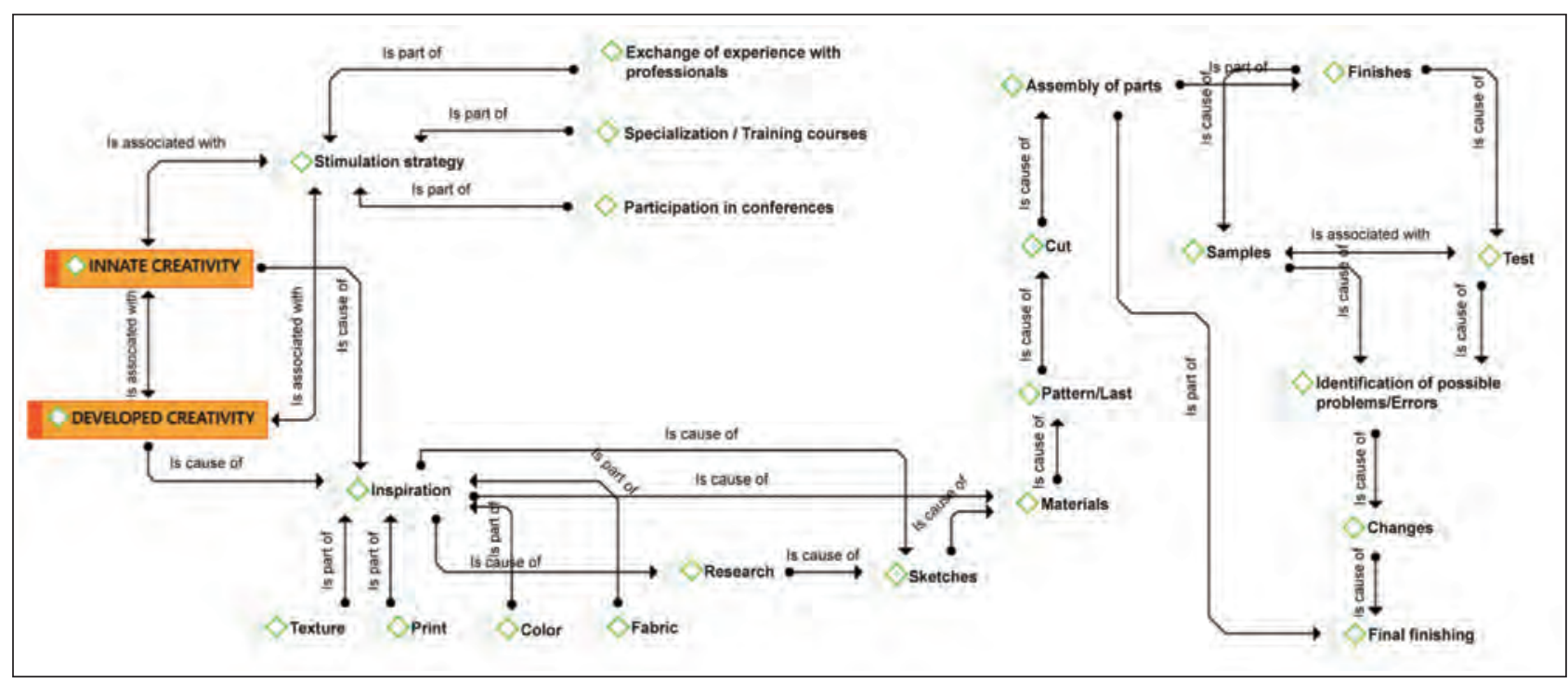

Fig. 3. The designers' perspectives on the creative process (processed using ATLAS.ti) 
shows that this pattern can be applied outside the creative industry. The origins of creativity, the attributes of creative people, the creative process and even the strategies to stimulate creativity can be transferred to any other field of activity, as they are not unique, and can thus contribute to a deeper understanding of the concept. Although the model has been validated by the research participants, they do not perceive it as the final outcome, but as a part/stage in the creative process. Since there are few studies conducted on the creativity of Romanian designers, our empirical study, through the obtained results, contributes to the literature by highlighting ways in which the entrepreneur designers manifest and develop their creativity in the context of the new business environment, in order to achieve sustainable competitive advantage.

This serves as proof that the business sector is one in which creativity can fit like a glove. Running a business is not an inhibiting factor for creativity. In fact, creativity can even be viewed as an art by anyone with an open mind, who is determined and willing to take risks while being able to identify opportunities and, in so doing, to bring out in an organized manner the latent potential of resources, so that in the end they can be used to create surplus value.

\section{LIMITS AND RECOMMENDATIONS}

We must keep in mind that this study is related to the designers' opinions of creativity in business and, as such, it provides a new perspective for future studies and additional approaches.

Regarding the answers analysed, it is necessary to pay attention to several limitations, out of which one of the main is the specific context: the fashion design industry in western Romania. Therefore, no generalization can be made regarding the entire creative sector. At the same time, the sample was partially self-selected, so our research could represent exclusively the opinion of those who were willing to participate in these interviews. The interviews largely involved the idea of introspection, and this can be considered difficult for those interviewed because they can omit certain relevant information. Although one of the limitations is the small number of interviewees, we chose a qualitative research to the detriment of a quantitative research because we sought a better understanding of the designers' ideas in certain situations, although this allows for the possibility of overestimating or underestimating them.

Future studies could support the present research if based on quantitative surveys mainly focused on the creativity of entrepreneur designers, and if the segmentation were targeted more precisely. Also, the features deemed irrelevant in the present paper might be revisited. Understanding creativity is necessary in the textile industry, and implicitly in fashion, as support for designers, because it can be the basis for improving education in the field: discovering a new idea by resorting to creativity is not enough to be successful, as creativity is a continuous process, just like education.

\section{ACKNOWLEDGEMENT}

This research was supported financially by the project CNFIS-FDI-2018-0582 - Supporting Excellence Research within The Bucharest University of Economic Studies in the context of the principles of sustainable development and open research. 6. Supporting field research excellence in universities Beneficiary: The Bucharest University of Economic Studies.

\section{REFERENCES}

[1] Gomes, J., Rodrigues, F., Veloso, A., Creativity at Work: The Role of Context, In: Human Resource Management, Innovation and Performance, London, Palgrave Macmillan, 2015, 282-297

[2] Guilford, J., The nature of human intelligence, New York: McGraw-Hill, 1967

[3] Torrance, E., The Minnesota studies of creative behavior: National and international extensions, In: Journal of Creative Behavior, 1967, 1, 137-154

[4] Amabile, T., Creativity in context, New York: Westview, 1996

[5] Vincent, A.S., Decker B.P., Mumford, M. D., Divergent thinking, intelligence, and expertise: A test of alternative models, In: Creativity Research Journal, 2002, 14, 163-178

[6] Ford, C.M., Gioia, D.A., Guidelines for creative action taking in organizations, In: Creative action in organizations: Ivory tower visions and real world voices, Thousand Oaks, Sage, 1995, 355-366

[7] Zhou, J., George, G.J.M., Awakening employee creativity: The role of leader emotional intelligence, In: Leadership Quarterly, 2003, 14, 545-568

[8] Florida, R., The rise of the creative class and how it's transforming work, leisure, community, and everyday life, New York, NY: Basic Books, 2002

[9] Vernon, D., Hocking, I., Tyler, T., An evidence-based review of creative problem solving tools, a practitioner's resource, In: Human Resource Development Review, 2008, 15, 2, 230-259

[10] Esquivias, M., Creatividad: definiciones, antecedentes y aportaciones, In: Revista Digital Universitaria, 2004, 5, 1, $1-17$

[11] Santos, C.M., Uitdewilligen, S., Passos, A.M., Why is Your Team More Creative Than Mine? The Influence of Shared Mental Models on Intra-group Conflict, Team Creativity and Effectiveness, In: Creativity and Innovation Management, 2015, 24, 4, 645-658

[12] Agogue, M., Levillain, K., Hooge, S., Gamification of creativity: Exploring the usefulness of serious games for ideation, In: Creativity and Innovation Management, 2015, 24, 415-429

[13] Behrens, J., A lack of insight: An experimental analysis of R\&D managers decision making in innovation portfolio management, In: Creativity and Innovation Management, 2016, 25, 239-250 
[14] Ludvig, A., Tahvanainen, V., Dickson, A., Evard, C., Kurttila, M., Kosovic, M., Gerhard, W., The practice of entrepreneurship in the non-wood forest products sector: Support for innovation on private forest land, In: Forest Policy and Economics, 2016, 66, 31-37

[15] Tu, C., Yang, S., The role of entrepreneurial creativity in entrepreneurial processes, In: International Journal of Innovation, Management and Technology, 2013, 4, 2, 286-289

[16] Howkins, J., The Creative economy - How people make money from ideas, London: Penguin Books, 2001

[17] Kohn, K., Wewel, S., Skills, scope and success: an empirical look at the start-up process in creative industries in Germany, In: Creativity and Innovation Management, 2018, 27, 3, 295-319

[18] Khan, R., "Be creative" in Bangladesh? Mobility, empowerment and precarity in ethical fashion enterprise, In: Cultural Studies, 2019, 33, 6, 1029-1049

[19] Aakko, M., Niinimäki, K., Fashion Designers as Entrepreneurs: Challenges and Advantages of Micro-size Companies, In: Fashion Practice, 2018, 10, 3, 354-380

[20] Mills, C., Enterprise orientations: a framework for making sense of fashion sector start $\square$ up, In: International Journal of Entrepreneurial Behavior \& Research, 2011, 17, 3, 245-271

[21] Kardos, M, Gabor, M.R., Cristache, N., Green Marketing's Roles in Sustainability and Ecopreneurship. Case Study: Green Packaging's Impact on Romanian Young Consumers' Environmental Responsibility, In: Sustainability, 2019, 3/11, 873

[22] Epuran, G., Tescasiu, B., Todor, R.D., Sasu, K.A., Cristache, N., Responsible Consumption - Source of Competitive Advantages and Solution for Tourist Protection, In: Revista Amfiteatru Economic, 2017, 19, 45, 447-463

[23] Karra, N., The UK Designer Fashion Economy. Value Relationships - Identifying Barriers and Creating Opportunities for Business Growth. A Report Commissioned for NESTA, Center for Fashion Enterprise, London, 2008

[24] Gu, X., Developing entrepreneur networks in the creative industries - a case study of independent designer fashion in Manchester, In: Handbook of Research on Small Business and Entrepreneurship, Cheltenham UK, Edward Elgar Publishing, 2014, 358-373

[25] Vaghely, I.P., Julien, P., Are opportunities recognized or constructed?, In: Journal of Business Venturing, 2010, 25, 1, 73-86

[26] Eliya, Y., Bibu, N., The Relation between Accountability and the Climate of Service in Israeli Public organisations, In: Revista de Management Comparat International/Review of International Comparative Management, 2019, 20, $1,30-51$

Authors:

$$
\begin{aligned}
& \text { DENISA BOGDANA ABRUDAN }{ }^{1} \text {, MĂDĂLINA DUMITRIȚA MATICIUC }{ }^{1} \text {, } \\
& \text { MARIAN NĂSTASE }{ }^{2} \text {, MARGARETA STELA FLORESCU², DANA CODRUȚA DĂIANU }{ }^{3}
\end{aligned}
$$

${ }^{1}$ West University of Timisoara, Faculty of Economics and Business Administration, Management Department, J.H. Pestalozzi Street, no.16, 300115, Timisoara, Romania e-mail: denisa.abrudan@e-uvt.ro, madalina.maticiuc@e-uvt.ro

${ }^{2}$ Bucharest University of Economic Studies, Faculty of Management, Management,

Piata Romana, no. 6, 010374, Bucharest, Romania

e-mail: margareta.florescu@ari.ase.ro

${ }^{3}$ Aurel Vlaicu University of Arad, Faculty of Economics, Economics Department, B-dul Revolutiei, no. 77, 310130, Arad, Romania

e-mail: cddaianu@yahoo.com

Corresponding author:

MARIAN NĂSTASE

e-mail: nastasem1@yahoo.com 


\title{
Attempts to improve the self-cleaning effect of the textile materials
}

\author{
DOI: 10.35530/IT.071.03.1626
}

IULIANA DUMITRESCU

LUCIA OANA SECĂREANU

OVIDIU-GEORGE IORDACHE

LAURENTIIU CHRISTIAN DINCĂ

CORNELIA-ELENA MITRAN

ARCADII SOBETKII

ELENA PERDUM

IRINA-MARIANA SĂNDULACHE

LUCIAN DIAMANDESCU

ABSTRACT - REZUMAT

\section{Attempts to improve the self-cleaning effect of the textile materials}

The objective of this study is to investigate the methods to create durable self-cleaning textiles by coating fabrics with $\mathrm{TiO}_{2}-(1 \%) \mathrm{Fe}-\mathrm{N}$-graphene (2\%). To improve the adherence of the nanoparticles, the polyester/cotton woven fabrics were pre-treated with polyacrylic acid (PA), carboxymethylcellulose (CMC) and polyethylene polyamine resin (EZF). The pre-treated materials were immersed in a doped $\mathrm{TiO}_{2}$ for 30 minutes at $40^{\circ} \mathrm{C}$ and dried at $125^{\circ} \mathrm{C}$. The finished fabrics were stained with methylene blue dye and exposed to visible light.

The SEM images show the presence of particles on polymers layers firmly attached on the material surface. The treatments determine the decrease of the exothermic peak $\left(452.48^{\circ} \mathrm{C}\right)$, characteristic of the cellulose decomposition, demonstrating an increase of the thermal conductivity of the materials. The doped $\mathrm{TiO}_{2}$-graphene induces a double degradation of methylene blue in comparison with untreated material and the materials treated with CMC, polyacrylic acid and cationic polymer. The effect is maintained after washing.

Keywords: doped $\mathrm{TiO}_{2}$-graphene, photocatalytic textiles, self-cleaning

\section{Încercări de îmbunătățire a efectului de auto-curățare al materialelor textile}

Obiectivul acestui studiu îl reprezintă cercetarea metodei de obținere a materialelor textile cu proprietăți de auto-curățare, durabile, prin acoperirea $\mathrm{cu} \mathrm{TiO}_{2}-(1 \%) \mathrm{Fe}-\mathrm{N}$-grafen (2\%). Pentru a îmbunătăți aderența nanoparticulelor, țesăturile din poliester/bumbac au fost pre-tratate cu acid poliacrilic (PA), carboximetilceluloză (CMC) și rășină polietilen poliamilică (EZF). Materialele textile pre-tratate au fost imersate în $\mathrm{TiO}_{2}$ dopat, timp de 30 de minute la $40^{\circ} \mathrm{C}$ și uscate la $125^{\circ} \mathrm{C}$. Țesăturile finisate au fost pătate cu albastru de metilen și expuse la lumină vizibilă.

Analiza SEM evidențiază prezența particulelor pe straturile polimerice, bine fixate pe suprafața materialului. Tratamentele determină scăderea vârfului exotermic $\left(452,48^{\circ} \mathrm{C}\right)$, caracteristic descompunerii celulozei, demonstrând o creștere a conductivității termice a materialului. $\mathrm{TiO}_{2}$-grafen dopat induce o dublă degradare a albastrului de metilen în comparație cu materialul netratat și materialele tratate cu CMC, acid poliacrilic și polimer cationic. Efectul se menține și după spălare.

Cuvinte-cheie: $\mathrm{TiO}_{2}$-grafen dopat, textile fotocatalitice, auto-curățare

\section{INTRODUCTION}

Self-cleaning textiles have many applications for protective uniforms, upholstery and carpets, window blinds, tents and awnings, filter fabrics, agricultural textiles, etc. [1]. Different compounds were tested to improve the photocatalytic self-cleaning efficiency such as $\mathrm{TiO}_{2}$ doped with metals, non-metals, metalsno-metals co-doping, dyes, heterojunctions $\left(\mathrm{ZnO} / \mathrm{TiO}_{2}\right.$; $\mathrm{TiO}_{2} / \mathrm{SiO}_{2} ; \mathrm{TiO}_{2} / \mathrm{WO}_{3}$ ). Recently, doped $\mathrm{TiO}_{2}$-graphene nanocomposites are intensive investigated due their efficiency to decompose pollutants and pathogenic microorganisms under visible light [2-6]. It is largely accepted that the high interfacial contact between graphene sheet and $\mathrm{TiO}_{2}$ nanoparticles facilitates the charge separation and electron transfer from $\mathrm{TiO}_{2}$ to graphene upon irradiation and overcome the fast recombination of the electrons and holes pairs, improving the photocatalytic activity [7].
Different physical and chemical methods were proposed for the immobilization of graphene- $\mathrm{TiO}_{2}$ on textiles such as atmospheric pressure metal organic chemical vapor deposition, electron beam evaporation, reactive magnetron sputtering, spray pyrolysis, sol-gel, and layer by layer assembly technique [8]. The most used method to prepare self-cleaning textiles remains the dip-pad-dry-cure method [9-11] due its large applicability on conventional production lines. The major drawback of immobilized $\mathrm{TiO}_{2}$ composites is the low coating adherence.

The objectives of this study are to investigate the methods to create durable self-cleaning textiles by coating fabrics with $\mathrm{TiO}_{2}-(1 \%) \mathrm{Fe}-\mathrm{N}$-graphene $(2 \%)$. To improve the adherence of the nanoparticles, the polyester/cotton woven fabrics were pre-treated with polyacrylic acid (PA), carboxymethylcellulose (CMC) and polyethylene polyamine resin (EZF). 


\section{EXPERIMENTAL}

\section{Materials}

Scoured and bleached 33\% cotton $/ 67 \%$ polyester woven fabric, $\mathrm{TiO}_{2}-(1 \%) \mathrm{Fe}-\mathrm{N}$-graphene (2\%), polyacrylic acid $(M w t=138.1 \mathrm{~g} / \mathrm{mol})$, carboxymethylcellulose $(C M C)$ and polyethylene polyamine resin (ITOFIX EZF, Fast Colours, UK), sodium dodecylhydrogenesulfate (DHS, Merck), Tween 80 (Sigma Aldrich), ethanol, a-terpineol (Merk), Imerol JSF (Archroma).

\section{Methods}

Preparation of $0.7 \mathrm{~g} / \mathrm{l} \mathrm{TiO}_{2}-(1 \%) \mathrm{Fe}-\mathrm{N}$-graphene (2\%) dispersion

To prepare the dispersion, in a 2 l reactor were successively added under intensive stirring on ultrasonic bath the following compounds: $527 \mathrm{ml}$ of water, $351 \mathrm{ml}$ of ethanol, $88 \mathrm{ml}$ of terpineol, $4.5 \mathrm{ml}$ of EHS, $17.5 \mathrm{ml}$ of Tween $80,10.5 \mathrm{ml}$ of Imerol JSF, $0.8 \mathrm{~g}$ DHS and $0.7 \mathrm{~g}$ doped $\mathrm{TiO}_{2}$-graphene. The mixture was stirred at $40^{\circ} \mathrm{C}$ for $60 \mathrm{~min}$. A white-gray dispersion is formed.

Fabric treatment

Cotton/polyester fabrics were separately immersed in $1 \mathrm{~g} / \mathrm{l}$ carboxymethylcellulose (CMC), $1 \mathrm{~g} / \mathrm{l}$ polyacrylic acid (PA) and $10 \mathrm{~g} / \mathrm{l}$ Itofix EZF solutions, kept at $80^{\circ} \mathrm{C}$ for 20 minutes and then, dried at $120^{\circ} \mathrm{C}$. The pretreated, dried materials are immersed in $0.7 \mathrm{~g} / \mathrm{l} \mathrm{TiO}{ }_{2}$ (1\%) Fe-N-graphene (2\%) dispersion, maintained under stirring at $40^{\circ} \mathrm{C}$ for 30 minutes and dried in the preheated oven at $125^{\circ} \mathrm{C}$.

Material abbreviation is the following:

A: cotton/polyester fabric immersed in $\mathrm{TiO}_{2}$-graphene dispersion;

CMC: cotton/polyester fabric immersed in $1 \mathrm{~g} / \mathrm{l} \mathrm{CMC;}$ $\mathrm{B}$ : cotton/polyester fabric immersed in $1 \mathrm{~g} / \mathrm{l} \mathrm{CMC}$ and later in $\mathrm{TiO}_{2}$-graphene dispersion;

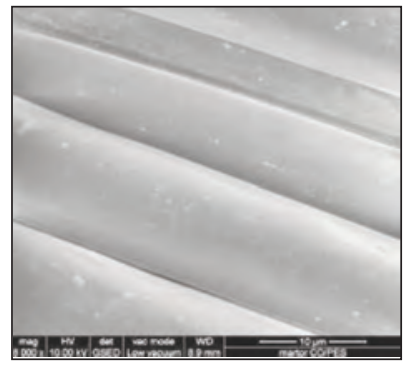

Untreated material

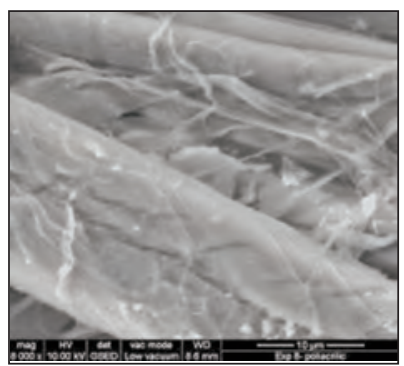

PA

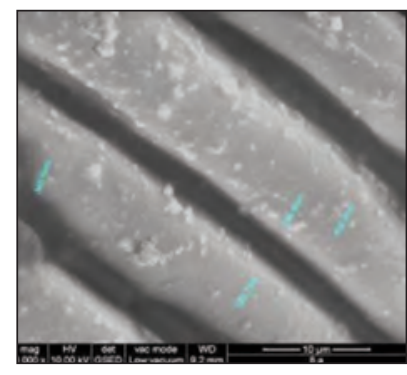

A

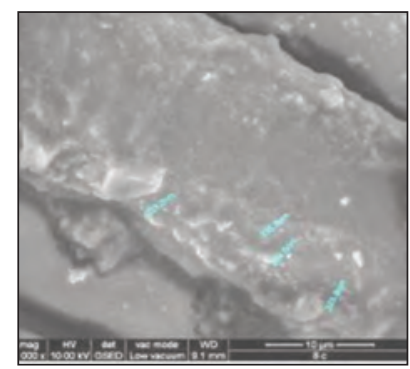

C

PA: cotton/polyester fabric immersed in $1 \mathrm{~g} / \mathrm{l}$ polyacrylic acid;

C: cotton/polyester fabric immersed in $1 \mathrm{~g} / \mathrm{l}$ polyacrylic acid and subsequently in $\mathrm{TiO}_{2}$-graphene dispersion;

EZF: cotton/polyester fabric immersed in $10 \mathrm{~g} / \mathrm{l}$ Itofix $E Z F$;

D: cotton/polyester fabric immersed in Itofix EZF and later in $\mathrm{TiO}_{2}$-graphene dispersion.

\section{Characterization}

The morphology of the fabric was investigated by scanning electron microscope (SEM, Quanta 200, FEI, Holland). The wetting ability was determined by measuring the contact angles of $5 \mu$ l distilled water droplet on a VCA Optima (AST Products Inc., USA) instrument. The results are the average of 5-10 measurements in different points on the samples surface. The thermal properties of the coated fabric were measured on DSC (Pyris Diamond, Perkin Elmer, USA) instrument, with a heating rate of $10^{\circ} \mathrm{C} /$ minute and using $10 \mathrm{ml} /$ minute air as a purging gas. The electrical resistivity was measured with PRS 801 digital multi-meter (Prostat Corporation, USA), according standard SR EN $1149-1: 2006$, at $20.7^{\circ} \mathrm{C}$ and $28.8 \%$ relative humidity. The photocatalytic efficiency of the untreated and treated materials was evaluated initially and after 5 washing cycles, by measuring the trichromatic coordinates of materials stained with methylene blue and exposed at UV and visible light on Hunterlab spectrophotometer, with CIELAB 1976 color space and D65-light source.

\section{RESULTS AND DISSCUSION}

\section{Characterization of the fabric by Scanning} Electron Microscopy (SEM)

The spreading of the particles and their size on the surfaces of the treated fabrics are shown on the SEM images (figure 1).

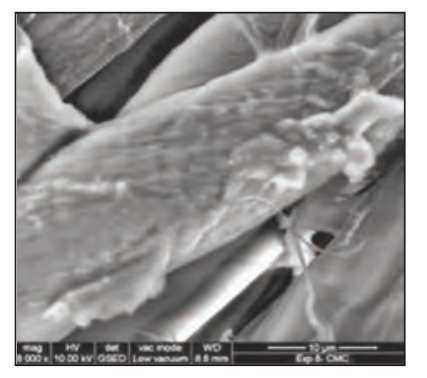

CMC

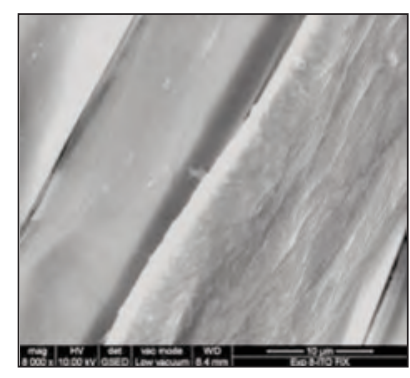

EZF

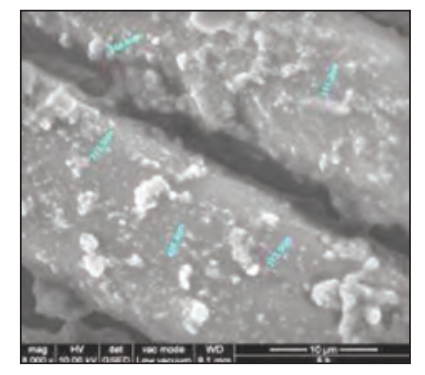

B

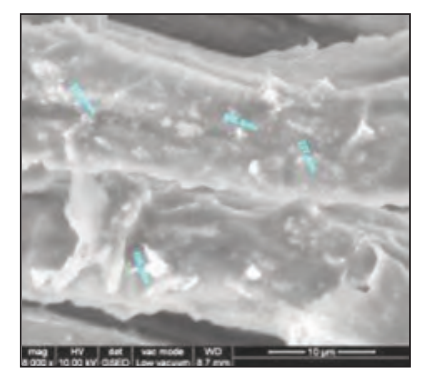

D

Fig. 1. SEM images of untreated and treated fabrics 


\begin{tabular}{|c|c|c|c|c|c|c|c|c|}
\hline \multicolumn{9}{|c|}{ IMAGES OF WATER DROPLETS AND CONTACT ANGLE VALUES } \\
\hline Sample & \multicolumn{2}{|c|}{ Untreated fabric } & \multicolumn{2}{|c|}{ CMC } & \multicolumn{2}{|c|}{ PA } & \multicolumn{2}{|c|}{ EZF } \\
\hline $\begin{array}{c}\text { Contact angle } \\
\text { left/right }\left(^{\circ}\right)\end{array}$ & 133.22 & 133.45 & 137.02 & 136.22 & 129.02 & 130.37 & 134.92 & 135.32 \\
\hline Image & & & & & & & & \\
\hline
\end{tabular}

SEM images show the $\mathrm{TiO}_{2}$ particles on cotton/ polyester woven fabric samples, before and after treatments. The samples CMC, PA, EZF are covered with thick layers of polymers. After the immersion in the doped- $\mathrm{TiO}_{2}-$ graphene dispersion, a large number of particles cover the fibers surface. The particles are in a larger number and more uniformly spread on the surface of the fabric coated only with doped $-\mathrm{TiO}_{2}$-graphene $(\mathrm{A})$ than on the surface of the samples covered with polymers and $\mathrm{TiO}_{2}$-graphene

\begin{tabular}{|c|c|c|c|}
\hline \multicolumn{4}{|c|}{ MATERIALS ELECTRICAL RESISTIVITY } \\
\hline Sample & $\begin{array}{c}\text { Surface resistivity } \\
\left(\Omega \mathbf{s q} \times \mathbf{1 0}^{\mathbf{1 3}}\right)\end{array}$ & $\begin{array}{c}\text { Volume resistivity } \\
\left(\Omega \times \mathbf{c m} \times \mathbf{1 0}^{\mathbf{1 5}}\right)\end{array}$ & $\begin{array}{c}\text { Thickness } \\
(\mathbf{m m})\end{array}$ \\
\hline Untreated material & 29.5 & 2.67 & 0.40 \\
\hline A & 42.5 & 11.2 & 0.41 \\
\hline CMC & 15.5 & 9.09 & 0.44 \\
\hline B & 63 & 2.48 & 0.43 \\
\hline PA & 15.5 & 8.82 & 0.43 \\
\hline C & 25 & 43.3 & 0.43 \\
\hline EZF & 20.5 & 10.5 & 0.44 \\
\hline D & 35 & 4.33 & 0.43 \\
\hline
\end{tabular}
$(B, C, D)$. As it can be seen from images, the particles are more agglomerated on the fabric $B$, covered initially with $\mathrm{CMC}$, probably due to porous surface of CMC and carboxyl groups which attract $\mathrm{TiO}_{2}$ particles.

\section{Surface wettability of the treated fabrics}

Due to the high content of thin polyester yarns and tight structure of the fabric, the untreated woven material is highly hydrophobic (contact angle of $133^{\circ}$ ). The hydrophoby of the materials is not significantly changed (table 1 ) if the materials are covered with polymers. After the $\mathrm{TiO}_{2}$-graphene treatment, the water static contact angle becomes zero, the water droplet being absorbed in less than 60 seconds, indicating a completely water wettability of the fabrics. The increased hydrophilic behavior of the materials could be correlated with the deposition of a large number of $\mathrm{TiO}_{2}$ particles on the materials surface knowing that graphene has water and oil repellency properties [12].

\section{Evaluation of the electrical resistivity}

The results of the materials' electrical resistivity are shown in the table 2.

Cotton/polyester fabric has anionic properties due to the hydroxyl and carboxyl groups respectively. By depositing layers of carboxymethylcellulose (sample $\mathrm{CMC}$ ) and polyacrylic acid (sample PA), the anionic character is accentuated leading to the decrease of the surface electrical resistivity. A smaller decrease of the electrostatic was observed for the fabric EZF covered with polyethylene polyamine layers. The materials coated with polymers and $\mathrm{TiO}_{2}$-graphene show higher electrical resistivities due to the thick layers and large agglomerates formed on the cotton/ polyester surface [13].

\section{Thermal conductivity}

The thermal behavior of the coated samples is shown in the figure 2 and tables 3 and 4 .

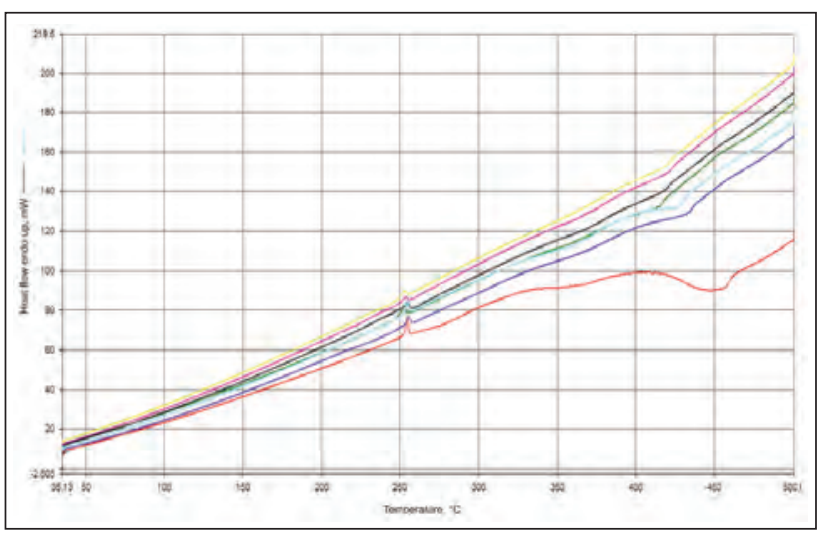

Fig. 2. DSC thermograme: $D$ - yellow; $C$ - purple; $\mathrm{B}$ - black; A - green; PA - blue; EZF - blue marine; $\mathrm{CMC}$ - red

The untreated material has 3 peaks, the first endotherm $\left(254.45^{\circ} \mathrm{C}\right)$ associated with the melting of the polyester yarns, the second $\left(353.11^{\circ} \mathrm{C}\right)$ associated 


\begin{tabular}{|c|c|c|c|c|c|c|c|c|c|}
\hline \multicolumn{10}{|c|}{ DSC RESULTS ANALYSES } \\
\hline Sample & \multicolumn{3}{|c|}{ Untreated material } & \multicolumn{2}{|c|}{ A } & \multicolumn{2}{|c|}{ CMC } & \multicolumn{2}{|c|}{ B } \\
\hline Weight (mg) & \multicolumn{3}{|c|}{3.4} & \multicolumn{2}{|c|}{3.7} & \multicolumn{2}{|c|}{2.8} & \multicolumn{2}{|c|}{2.5} \\
\hline Temp. max. $\left({ }^{\circ} \mathrm{C}\right)$ & 254.44 & 353.11 & 452.48 & 252.44 & 415.26 & 254.49 & 447.98 & 255.26 & 419.42 \\
\hline$\Delta \mathrm{H}(\mathrm{J} / \mathrm{g})$ & 26.95 & -77.97 & -210.54 & 22.73 & -16.47 & 31.93 & -638.79 & 12.39 & -3.75 \\
\hline Onset $\mathrm{t}\left({ }^{\circ} \mathrm{C}\right)$ & 253.30 & 340.86 & 435.32 & 249.38 & 407.16 & 252.38 & 418.27 & 252.32 & 415.57 \\
\hline
\end{tabular}

\begin{tabular}{|c|c|c|c|c|c|c|c|c|c|}
\hline \multicolumn{10}{|c|}{ DSC RESULTS ANALYSES } \\
\hline Sample & \multicolumn{3}{|c|}{ PA } & \multicolumn{2}{|c|}{ C } & \multicolumn{2}{|c|}{ EZF } & \multicolumn{2}{|c|}{ D } \\
\hline Weight (mg) & \multicolumn{3}{|c|}{2.8} & \multicolumn{2}{|c|}{2.4} & \multicolumn{2}{|c|}{2.3} & \multicolumn{2}{|c|}{-} \\
\hline Temp. max. $\left({ }^{\circ} \mathrm{C}\right)$ & 254.45 & 427.13 & 253.77 & 422.27 & 255.26 & 432.67 & 252.77 & 420.33 & 419.42 \\
\hline$\Delta \mathrm{H}(\mathrm{J} / \mathrm{g})$ & 28.994 & -133.4490 & 9.5335 & 0.6313 & 24.8835 & -52.8754 & 19.3429 & -4.9547 & -3.75 \\
\hline Onset $\mathrm{t}\left({ }^{\circ} \mathrm{C}\right)$ & 252.87 & 410.75 & 251.41 & 421.10 & 253.16 & 425.03 & 249.58 & 416.98 & 415.57 \\
\hline
\end{tabular}

with possible fiber impurities and the third endotherm $\left(452.48^{\circ} \mathrm{C}\right)$ associated with the burning of cotton [14]. Covering the materials with polymers and with $\mathrm{TiO}_{2}$ graphene, causes the enthalpy decrease of both fibers. It is possible that this decrease is due to the uneven deposition of the compounds, which leads to localized growth of thermal conductivity.

\section{Photocatalytic efficiency}

The aspect and the color modifications of the materials stained with methylene blue exposed 4 hours to visible light, are shown in the tables 5 and 6 .

As the notes on grey scale demonstrate, the doped $\mathrm{TiO}_{2}$-graphene induces a double degradation (table 6) of the methylene blue in comparison with untreated material and the materials treated with CMC, polyacrylic acid and cationic polymer. The highest lightness difference $\left(\mathrm{dL}^{*}\right)$ is recorded for sample a, coated with $\mathrm{TiO}_{2}$ /graphene. Instead, the highest color difference is recorded on the sample $D$, initially treated with the cationic polymer, followed in descending order by samples A, C and B. Probably, this effect is determined both by the uneven deposition of polymer layers and the blocking of a portion of $\mathrm{TiO}_{2}$ by the functional groups of the polymers (- carboxyl groups). The hypothesis is confirmed by the $\mathrm{dL}^{*}$ and $\mathrm{dE}^{*}$ values of samples treated only with polymers that decrease in the order: $\mathrm{PA}>\mathrm{CMC}>\mathrm{EZF}$.

ASPECT OF THE MATERIALS EXPOSED 4 HOURS AT VISIBLE LIGHT (XENOTEST)

\begin{tabular}{|c|c|c|c|c|}
\hline Time (hours) & Blank & CMC & Polyacrylic acid & EZF \\
\hline 0 & & & & \\
\hline
\end{tabular}




\begin{tabular}{|c|c|c|c|c|c|c|c|c|c|}
\hline \multicolumn{10}{|c|}{$\begin{array}{c}\text { TRICHROMATIC COORDINATES OF THE MATERIALS STAINED WITH MB AND EXPOSED } 4 \text { HOURS } \\
\text { TO VISIBLE LIGHT }\end{array}$} \\
\hline Sample & $L^{*}$ & $a^{*}$ & $\mathbf{b}^{*}$ & $\mathrm{dL}^{*}$ & $d^{*}$ & $\mathrm{db}^{*}$ & $\mathrm{dE}^{*}$ & $\begin{array}{l}\text { Strength } \\
\text { SUM (\%) }\end{array}$ & Note \\
\hline Blank & 67.61 & -3.10 & -28.66 & 1.85 & 5.31 & 9.94 & 11.42 & 67.49 & 2.00 \\
\hline A & 77.74 & -3.10 & -11.37 & 8.86 & 10.32 & 12.62 & 18.55 & 47.67 & 1.00 \\
\hline CMC & 63.66 & -3.43 & -31.42 & 2.20 & 1.19 & 10.23 & 10.53 & 72.66 & 2.00 \\
\hline$B$ & 80.85 & -2.19 & -11.47 & 6.62 & 10.48 & 9.35 & 15.53 & 54.90 & 1.00 \\
\hline PA & 77.42 & -2.22 & -23.73 & 4.93 & 6.15 & 10.67 & 13.27 & 67.49 & 1.50 \\
\hline C & 79.52 & -1.59 & -10.14 & 6.62 & 10.44 & 10.56 & 16.26 & 55.72 & 1.00 \\
\hline$E Z F$ & 83.41 & -0.74 & -16.86 & 0.15 & 8.11 & 3.93 & 9.01 & 78.84 & 1.50 \\
\hline$D$ & 75.37 & -4.88 & -12.03 & 8.68 & 10.19 & 14.96 & 20.07 & 44.98 & 1.00 \\
\hline
\end{tabular}

Carboxymethyl cellulose (CMC) contains several carboxymethyl $\left(-\mathrm{CH}_{2}-\mathrm{COOH}\right)$ groups linked to the hydroxyl groups of the glucopyranosyl rings and interacts with a larger number of $\mathrm{TiO}_{2}$ molecules than polyacrylic acid, inhibiting the photocatalytic activity. Consequently, as the results show, the discoloration of methylene blue is more intense on the sample treated with polyacrylic acid and $\mathrm{TiO}_{2}$ /graphene (sample $\mathrm{C}, \mathrm{dE}^{*}=16.26$ ) than that on the sample treated with $\mathrm{CMC}$ and $\mathrm{TiO}_{2}$ /graphene (sample $\mathrm{B}$, $\left.\mathrm{dE}^{*}=15.53\right)$. This demonstrates that the discoloration is induced by the photocatalytic effect of $\mathrm{TiO}_{2}$. graphene and not by any possible absorption of the dye by the polymers although the CMC is amorphous and according to SEM images is deposited in thicker layers than the polyacrylic acid.

The photocatalytic properties of the samples on the degradation of methylene blue (MB), in visible $(\lambda>400$ $\mathrm{nm})$ spectral regions $(\sim 1 \mathrm{~mW}$; at the irradiance of $2.5 \mathrm{~W} / \mathrm{m}^{2}$ ) were also measured by a PCC-2 (ULVAC RIKO, Chigasaki, Kanagawa, Japan) photocatalytic checker. The absorbance (ABS) is a measure of the photocatalytic efficiency of sample, higher negative values indicating better activity. The ABS values of the samples are depicted in the figure 3 .

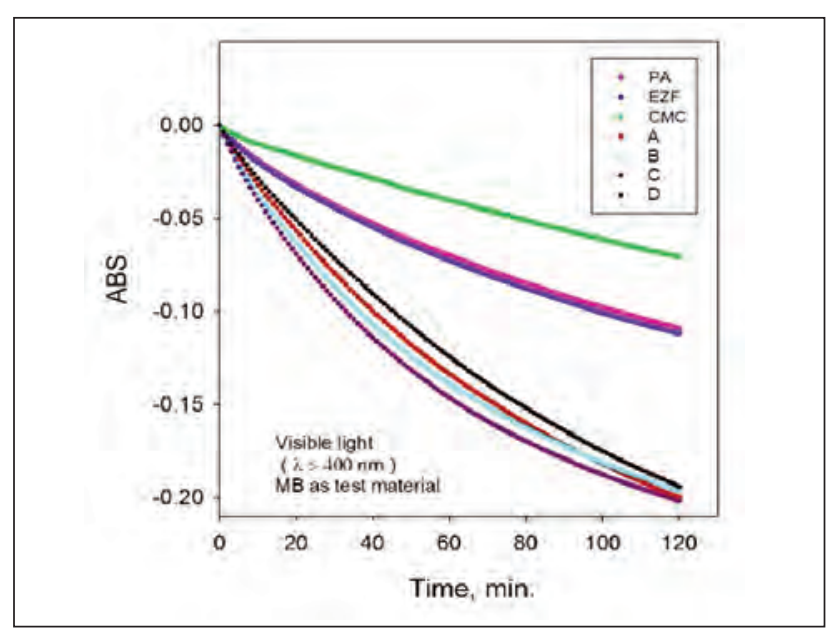

Fig. 3. The photocatalytic activity of the samples on the degradation of methylene blue
As the graph shows, the most intensive efficiency is demonstrated by the samples $\mathrm{c}$ and d (after 2 hours of exposure at visible light, almost $20 \%$ of dye is decomposed). No saturation tendency can be observed after 2 hours on irradiation in visible light. The slight differences between the two tests (UV-VIS spectrophotometry and photocatalytic checker) could be attributed to the intrisec non-uniformity of the textile materials and, accordingly to the deposited composites layers.

Evaluation of the photocatalytic effect after washing The treated materials were subjected to 5 washings at $40^{\circ} \mathrm{C}$ with distilled water. After drying, they were stained with $0.064 \mathrm{~g} / \mathrm{MB}$ for 20 minutes at $30^{\circ} \mathrm{C}$. The stained materials were exposed to visible light, the appearance and results of color change measurements being shown in tables 7 and 8 .

All the materials treated with $\mathrm{TiO}_{2}$-graphene preserve their photocatalytic efficiency after 5 washing cycles. According to the values of lightness and color differences, the highest photodegradation is shown by samples $C$ and $D$, pre-treated with polyacrilic acid and, respectively Itofix EZF and then with doped $\mathrm{TiO}_{2}$-graphene.

\section{CONCLUSIONS}

The SEM/EDAX analyses confirm the deposition of $\mathrm{TiO}_{2}$-graphene on fabrics. The fabrics coated with doped $\mathrm{TiO}_{2}$-graphene particles are highly hydrophilic due to the deposition of a high number of hydrophilic $\mathrm{TiO}_{2}$ particles on the materials surface. All the treated fabrics have electrical resistivity in the same range as untreated cotton/polyester.

The coated cotton/polyester fabrics with graphene oxide $/ \mathrm{TiO}_{2}$ nanocomposite show good photocatalytic self-cleaning activity evaluated by degradation of methylene blue under visible light irradiation. The used polymers promote greater adherence of the $\mathrm{TiO}_{2}$-graphene particles to the substrate demonstrated by the maintenance of the photocatalytic efficiency after 5 washing cycles. 
ASPECT OF THE MATERIALS EXPOSED 4 HOURS AT VISIBLE LIGHT (XENOTEST)ASPECT OF TREATED MATERIALS ACCORDING TO EXP. 8 AFTER 5 WASHES, EXPOSED 8 HOURS IN VISIBLE LIGHT

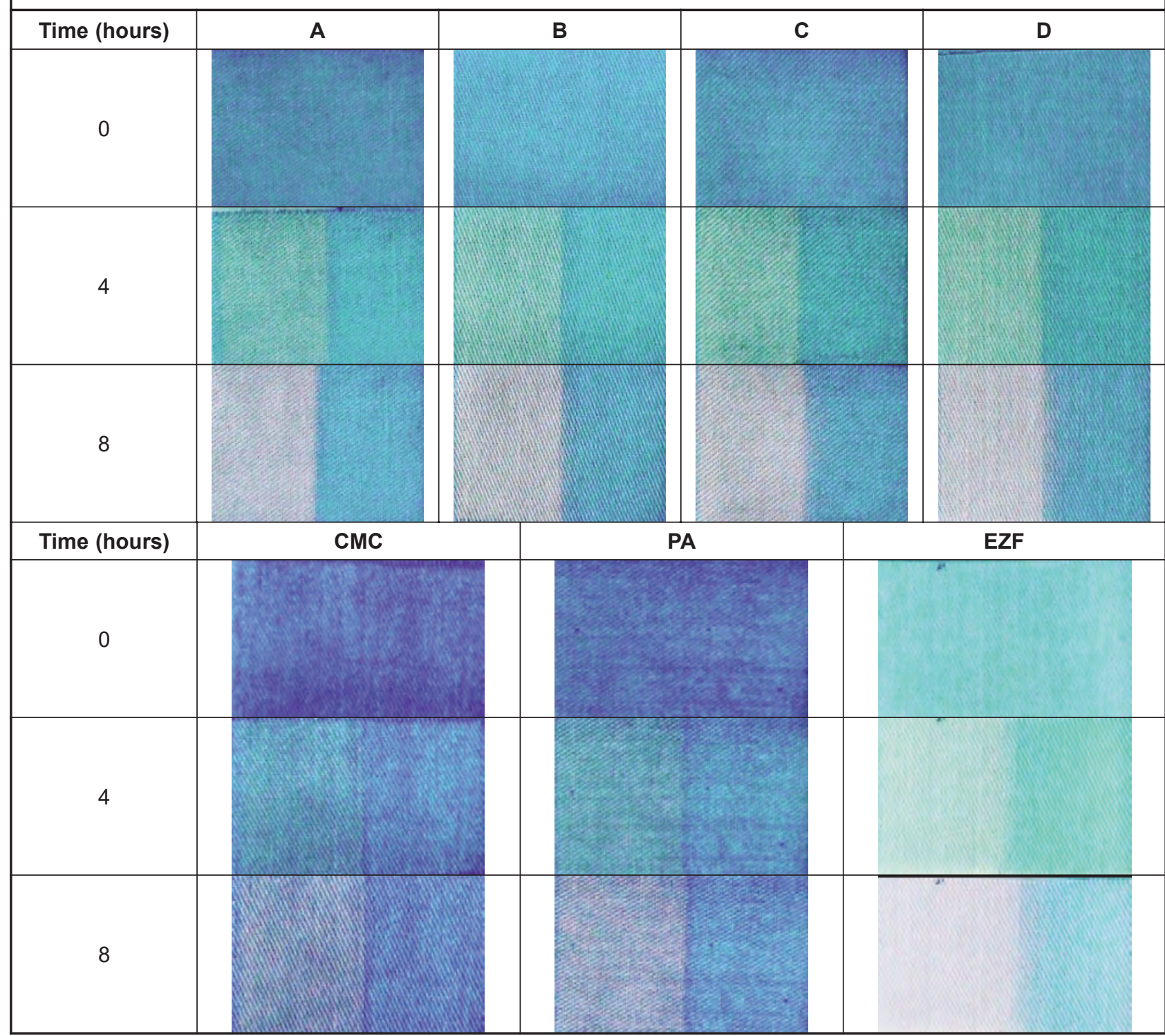

Table 8

TRICHROMATIC CO-ORDINATES OF THE MATERIALS AFTER 5 WASHES, EXPOSED 8 HOURS IN VISIBLE LIGHT (XENOTEST)

\begin{tabular}{|c|c|c|c|c|c|c|c|c|c|}
\hline Sample & $\mathbf{L}^{*}$ & $\mathbf{a}^{*}$ & $\mathbf{b}^{*}$ & $\mathbf{d L ^ { * }}$ & $\mathbf{d a *}$ & $\mathbf{d} \mathbf{b}^{*}$ & $\mathbf{d E}$ & $\begin{array}{l}\text { Strength } \\
\text { SUM (\%) }\end{array}$ & Note \\
\hline A & 74.92 & -1.07 & -10.60 & 9.36 & 12.01 & 20.98 & 25.92 & 44.35 & 1 \\
\hline CMC & 66.62 & -2.18 & -21.49 & 5.36 & 3.39 & 19.69 & 20.69 & 58.08 & 1 \\
\hline PA & 69.43 & -1.29 & -19.75 & 5.79 & 6.83 & 19.84 & 21.76 & 51.78 & 1 \\
\hline B & 75.89 & -0.73 & -9.75 & 10.44 & 11.82 & 20.92 & 26.20 & 46.13 & 1 \\
\hline C & 77.30 & -0.42 & -9.87 & 11.53 & 11.80 & 22.77 & 28.12 & 38.13 & 1 \\
\hline D & 77.96 & -0.50 & -9.13 & 11.50 & 12.21 & 21.37 & 27.17 & 38.19 & 1 \\
\hline EZF & 84.37 & 2.07 & -12.75 & 3.62 & 12.21 & 9.87 & 16.11 & 73.12 & 1 \\
\hline
\end{tabular}

\section{ACKNOWLEDGMENTS}

This work was supported by a research grant from The Executive Unit for Financing Higher Education, Research,
Development and Innovation (UEFISCDI) in the frame of Partnership PN II Program (Project No. 87/2014 - CLEANTEX). 


\section{REFERENCES}

[1] Gupta, D., Gulrajani, M.L., Self-cleaning finishes for textiles, available on-line, Available at: https://www.researchgate.net/publication/282482555_Self_cleaning_finishes_for_textiles [Accessed July 4th 2017]

[2] Vinu, R., Giridhar, M., Environmental remediation by photocatalysis, In: Journal of the Indian Institute of Science, 2010, 90, 2

[3] Norouzi, M., Maleknia, L., Photocatalytic Effects of Nanoparticles of TiO2 in Order to Design Self-Cleaning Textiles, In: Asian Journal of Chemistry, 2010, 22, 8, 5930-5936

[4] Wojtoniszak, M., Zielinska, B., Chen, X., et al., Synthesis and photocatalytic performance of $\mathrm{TiO}_{2}$ nanospheres-graphene nanocomposite under visible and UV light irradiation, In: J. Mater. Sci., 2012, 47, 3185-3190

[5] Zhang, H., Lv, X., Li, Y., et al., P25-graphene composite as a high performance photocatalyst, In: ACS Nano., 2009, 4, 380-386

[6] Nica, I.C., Stan, M.S., Popa, M., Chifiriuc, M.C., Lazar, V., Pircalabioru, G.G., Dumitrescu, I., Ignat, M., Feder, M., Tanase, L.C., Mercioniu, I., Diamandescu, L., Dinischiotu, A., Interaction of new-developed $\mathrm{TiO}_{2}$-based photocatalytic nanoparticles with pathogenic microorganisms and human dermal and pulmonary fibroblasts, In: Int. J. Mol. Sci., 2017, 18, 249

[7] Venkata, R.P., Viswadevarayalu, A., Janardhan R.K., Prathima B., Madhavi, V., Adinarayana R.S., Preparation of graphene- $\mathrm{TiO}_{2}$ nanocomposite and photocatalytic degradation of Rhodamine $B$ under solar light irradiation, In: Journal of Experimental Nanoscience, 2016, 11, 9, 722-736, https://doi.org/10.1080/17458080.2016.1144937

[8] Zgura, I., Frunza, S., Enculescu, M., Florica, C., Cotorobai, F., Deposition of titanium dioxide layers upon polyester textile materials: Checking the adherence by ultra-sonication, In: Rom. Journ. Phys., 2015, 60, 3-4, 488-494

[9] Yuranova, T., Laub, D., Kiwi, J., Synthesis, activity and characterization of textiles showing self-cleaning activity under daylight irradiation, In: Catal. Today, 2007, 122, 109-117

[10] Abidi, N., Cabrales, L., Hequet, E., Functionalization of a cotton fabric surface with titania nanosols: Applications for self-cleaning and UV-protection properties, In: ACS Appl. Mater. Interfaces 2009, 1, 2141-2146

[11] Kiwi, J., Pulgarin, C., Innovative self-cleaning and bactericide textiles, In: Catal. Today, 2010, 151, 2-7

[12] Hsieh, C.T., Chen, W., Water/oil repellency and work of adhesion of liquid droplets on graphene oxide and graphene surfaces, In: Surf Coatings Technol., 2011, 205, 4554-4561

[13] Deshmukha, H.P., Shinde, P.S., Patil, P.S., Structural, optical and electrical characterization of spray-deposited TiO2 thin films, In: Materials Science and Engineering, 2006, B, 130, 220-227

[14] Lin, L., et al., Preparation and properties of a washable flame-retardant coated fabric, In: Indian Journal of Fibre \&Textile Research, 2016, 41, 40-46

Authors:

IULIANA DUMITRESCU - In memoriam

OVIDIU-GEORGE IORDACHE1', CORNELIA-ELENA MITRAN',

ELENA PERDUM ${ }^{1}$, IRINA-MARIANA SĂNDULACHE ${ }^{1}$,

LUCIA OANA SECĂREANU ${ }^{1}$, LAURENȚIU CHRISTIAN DINCĂ ${ }^{1}$, ARCADII SOBETKII ${ }^{2}$, LUCIAN DIAMANDESCU ${ }^{3}$

${ }^{1}$ National Research and Development Institute for Textile and Leather - INCDTP, 16 Lucretiu Patrascanu Street, 030508, Bucharest, Romania e-mail: office@incdtp.ro

${ }^{2}$ National Research-Development Institute for Non-Ferrous and Rare Metals - IMNR, 102 Biruintei Blvd., 077145, Pantelimon, Ilfov, Romania

${ }^{3}$ National Institute of Materials Physics - NIMP, 405 A, Atomistilor Street, Bucharest-Măgurele, Romania

Corresponding author:

OVIDIU-GEORGE IORDACHE

e-mail: ovidiu.iordache@incdtp.ro 


\section{Validation method and proficiency test for the determination of free and hydrolysed formaldehyde}

DOI: 10.35530/IT.071.03.1423

LUCIA OANA SECĂREANU

MIHAELA-CRISTINA LITE

ELENA PERDUM

CORNELIA-ELENA MITRAN

OVIDIU-GEORGE IORDACHE

Validation method and proficiency test for the determination of free and hydrolysed formaldehyde

Formaldehyde resins are usually used in the textile industry to prevent wrinkling, as well as for conservation of textile artifacts. The International Agency for Research on Cancer (IARC) classified formaldehyde as carcinogenic to humans. There are several regulations regarding the amount of formaldehyde found in textiles, for example Oeko-Tex Standard 100, REACH and European Ecolabel. In the present work, a spectrophotometric method for quantitative determination of free and hydrolyzed formaldehyde extracted through partial hydrolysis by using aqueous extraction was developed and validated. The method is in conformity with SR EN ISO 14184-1:2012 standard. The results of the validation parameters are $0.0117 \mathrm{mg} / \mathrm{l}$ for detection limit and $0.039 \mathrm{mg} / \mathrm{l}$ for quantification limit. The working field was proved to be linear in $0.15 \mu \mathrm{g} \mathrm{CH}$ parameter value is $89.80 \%$. Selectivity was determined in relation to acetic anhydride and the spectrophotometric method was proven to be selective for the quantitative determination of formaldehyde. Besides the validation method, a control diagram has been constructed by measuring a solution of known concentration 10 times. The selected concentrations are $0.16 \mathrm{mg} / \mathrm{l}$ and $0.75 \mathrm{mg} / \mathrm{l}$. These solutions are measured before the actual samples. To ensure the accuracy of the results, our laboratory participated to a proficiency test conducted by ASQUAL. The z-score obtained was 0.38 and the number of participating laboratories was 13.

Keywords: formaldehyde, textile, ecology, validation method, proficiency test

\section{Metodă de validare și teste interlaboratoare pentru determinarea formaldehidei libere și hidrolizate}

Rășinile pe bază de formaldehidă sunt, de obicei, utilizate în industria textilă pentru prevenirea șifonării materialelor și, de asemenea, pentru conservarea artefactelor textile. Agenţia Internaţională pentru Cercetarea Cancerului (IARC) a clasificat formaldehida drept carcinogenă pentru oameni. În prezent, există câteva organisme pentru regularizarea cantităţii de formaldehidă regăsită în materialele textile: Oeko-Tex Standard 100, REACH și European Ecolabel. În această lucrare a fost descrisă dezvoltarea și validarea unei metode spectrofotometrice pentru determinarea cantitativă a formaldehidei libere și hidrolizate extrasă prin hidroliză parţială, utilizând extracţia apoasă. Aceasta metodă este în conformitate cu standardul SR EN ISO 14184-1:2012. Rezultatele parametrilor de validare sunt 0,0117 mg/l pentru limita de detecţie și 0,039 mg/l pentru limita de cuantificare. Domeniul de lucru s-a dovedit a fi liniar în intervalul 0,15 $\mu \mathrm{g}$ $\mathrm{CH}_{2} \mathrm{O} / \mathrm{ml}-6,00 \mu \mathrm{g} \mathrm{CH} \mathrm{H}_{2} \mathrm{O} / \mathrm{ml}$, cu un coeficient de corelaţie de 0,999977. În plus, valoarea parametrului de recuperare este $89,80 \%$. Selectivitatea a fost determinată în raport cu anhidrida acetică, iar metoda spectrofotometrică s-a dovedit a fi selectivă, pentru determinarea cantitativă a formaldehidei. Pe lângă metoda de validare, a fost elaborată o diagramă de control, prin analiza unei soluţii de concentraţie cunoscută de 10 ori. Concentraţiile selectate sunt 0,16 mg/l și 0,75 mg/l. Aceste soluţii au fost analizate înaintea probelor propriu-zise. Pentru a asigura acurateţea rezultatelor, laboratorul nostru a participat la un test interlaboratoare condus de către ASQUAL. Scorul z obţinut a fost 0,38, iar numărul de laboratoare participante a fost 13.

Cuvinte cheie: formaldehidă, textile, ecologie, metodă de validare, teste interlaboratoare

\section{INTRODUCTION}

As the industry grows, more chemical products enter our life and come in contact with our skin or can be inhaled or ingested. One of these substances is formaldehyde [1]. Since its discovery, at the end of the nineteenth century, formaldehyde, also known as formalin, has been proven to possess antifungal and antimicrobial properties and, due to this reason, it has been also used as treatment for the conservation of textile artifacts [2-4]. Formaldehyde has been classified as carcinogenic to humans by IARC
(International Agency for Research on Cancer) [5]. Formaldehyde is a common precursor to more complex compounds and materials. The textile industry uses formaldehyde-based resins as finishing agents to make fabrics crease-resistant [6-7]. Formaldehyde is usually added to textile products to make them wrinkle-free, shrink proof, flame retardant and to maintain the durability of the printing and dyeing, or to improve the texture. Textile products and clothing containing formaldehyde will gradually release free formaldehyde [8]. Formaldehyde causes respiratory 
inflammation by inhalation and skin inflammation by skin contact and it also irritates the eyes.

Furthermore, prolonged exposure to formaldehyde may cause allergies and cancer. There are two standards for the determination of formaldehyde from textiles: one of them is ISO 14184-1:2012 "Determination of formaldehyde - part 1: free and hydrolyzed formaldehyde (water extraction method)" and the other one is ISO 14184-2:2012 "Determination of formaldehyde - part 2: released formaldehyde (vapor absorption method)". The amount of formaldehyde must not exceed 16 ppm [9-10]. In this paper, a method to determine the free and hydrolyzed formaldehyde from textiles is reported, the extraction being performed in distilled water. The method has been validated and the control method to improve the certainty of the obtained results has been established.

\section{EXPERIMENTAL}

\section{Validation method}

To validate this method, the following performance parameters have been determined: selectivity (specificity), limit of detection and limit of quantification, working range, analytical sensitivity, precision (repeatability and reproducibility) and recovery.

Selectivity (specificity)

Selectivity (specificity) is the ability of the method to measure the behaviour of the analyte in the presence of other impurities and compounds [11]. To evaluate this parameter, acetic anhydride (figure 1) and acetaldehyde (figure 2) have been measured trough spectrophotometric method in scan mode (350-480 $\mathrm{nm}$ range). The two solutions were prepared identically to the formaldehyde solutions, according to ISO 14184-1:2012. Moreover, the mixture of components that are mentioned in the working procedure and each component individually, including the analyte of interest have been analyzed. The concentrations are: $150 \mathrm{~g} / \mathrm{l}$ ammonium acetate, $3 \mathrm{ml} / \mathrm{l}$ acetic acid, $2 \mathrm{ml} / \mathrm{l}$ acetyl acetone, Nash reagent, $1.50 \mathrm{mg} / \mathrm{l}$ formaldehyde solution with Nash reagent and $6 \mathrm{mg} / \mathrm{l}$ formaldehyde solution with Nash reagent (Nash reagent is a solution obtained by the dissolution in distilled water of $75 \mathrm{~g}$ ammonium acetate, $1.5 \mathrm{ml}$ glacial acetic acid and $1 \mathrm{ml}$ acetylacetone in a dark $500 \mathrm{ml}$ volumetric flask).

Limit of detection (LOD) and limit of quantification (LOQ)

The limit of detection represents the lowest analyte concentration of a sample that can be detected with reasonable statistical certainty, but not necessarily quantified as an exact value under the established test conditions. In broad terms, the limit of detection is the lowest analyte concentration of a sample that can be safely distinguished from zero [12-13]. There are two types of detection limits: one for the instrument and one for the method. The LOD of the instrument is based on a sample analysis, measured using a spectrophotometer, without passing by the sample preparation. The LOD of the method is based on a sample analysis, measured with the spectrophotometer after it was passed through the entire working procedure. To determine the LOD of the method 10 blank samples have been prepared (Nash reagent with water $1: 1 \mathrm{v} / \mathrm{v}$ ) according to the working procedure and they were analyzed. LOD was calculated according to the formula: $L O D=0+3 \times S_{0}$. LOQ represents the lower concentration of analyte that can be measured with an acceptable performance. LOQ was calculated using the formula: $L O Q=0+10 \times S_{0}$. Working range and method linearity

The working domain (the working concentration range) is the interval between the upper and the lower concentration of the analyte in the sample (including these concentrations) for which the procedure has been shown to have an adequate level of accuracy, precision and linearity [14]. For the determination of formaldehyde concentration, the working range is between $0.15 \mu \mathrm{g}\left(15 \mathrm{mg} / \mathrm{kg} \mathrm{CH} \mathrm{CH}_{2} \mathrm{O} / 1 \mathrm{~g}\right.$ of fab-

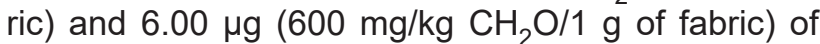
formaldehyde. To determine if the working range is suitable for the purpose of the method, 3 blank samples were submitted to UV-Vis spectrophotometer analysis and the 8 standard solutions $(0.1500 \mathrm{mg} / \mathrm{l}$, $0.30000 \mathrm{mg} / \mathrm{l}, 0.7500 \mathrm{mg} / \mathrm{l}, 1.5000 \mathrm{mg} / \mathrm{l}, 2.2500 \mathrm{mg} / \mathrm{l}$, $3.0000 \mathrm{mg} / \mathrm{l}, 4.5000 \mathrm{mg} / \mathrm{l}, 6.0000 \mathrm{mg} / \mathrm{l}$ ) were prepared according to SR EN ISO 14184-1:2012.

The linearity of a quantitative analytical method represents its ability to obtain results proportional to the concentration (quantity) of the analyte in the sample [13]. To evaluate the linearity, a calibration curve has been constructed, consisting of 8 concentration levels: 0.1275 (the concentration of the first solution is $15 \%$ lower than the one from the method), 0.3000 , $0.7500,1.5000,2.2500,3.0000,4.5000$ and 6.9000 $\mathrm{mg} / \mathrm{l}$ (the concentration of the last solution is $15 \%$ higher than the one from the method). The performance criteria are: the correlation coefficient to be 0.990000 , minimum and the curve to be linear.

Analytical sensitivity

The sensitivity of the analysis method represents the slope of the calibration curve or the regression coefficient [15]. To determine this parameter, a calibration curve in 8 points has been constructed.

Precision (repeatability and reproducibility)

The precision of the method is expressed by its repeatability and reproducibility. The description of repeatability is: the approximate results in a series of measurements from the same homogeneous sample under the same operating conditions, same analyst, same equipment, same laboratory and short operating time. The Repeatability Relative Standard Deviation (RSDR) ranges between $0.1-1.5 \%$ [13] To calculate the precision of the method a standard solution with concentrations of $2.5000 \mathrm{mg} / \mathrm{l}$ was submitted to ananlysis 10 times, in the same conditions. Reproducibility measures the dispersion of multiple measurement results for the same measurement, with the same method, in different laboratories, on identical samples, by different analysts using different equipment over a longer period of time. 


\section{Recovery}

Field recovery returns are accepted in $80-120 \%$ range for formaldehyde analysis using the spectrophotometric method. Three measurements were performed on an unfortified standard solution, on a fortified standard solution and on a fortified sample.

\section{Method robustness}

A RSD of up to $1 \%$ is acceptable for the determination of robustness. To evaluate the robustness of the method, three measurements of $2.25 \mathrm{mg} / \mathrm{l}$ formaldehyde solution after wavelength modification at 405 , 410 and $415 \mathrm{~nm}$ were performed.

\section{Proficiency test}

In order to confirm the precision and accuracy of the method, our laboratory participated at an inter-laboratory test organized by ASQUAL. A number of 13 laboratories took part at this study.

\section{Confirmation of the instrument performance}

To evaluate the quality of the equipment used for the analyis, a spectrum for a holmium oxide standard solution was recored.

\section{Uncertainty determination}

In order to calculate the uncertainty of the method it is necessary to take into account all the factors than can generate errors. Examples of such factors are: pipettes, volumetric flasks, analytical balance, the purity of the reagents used.

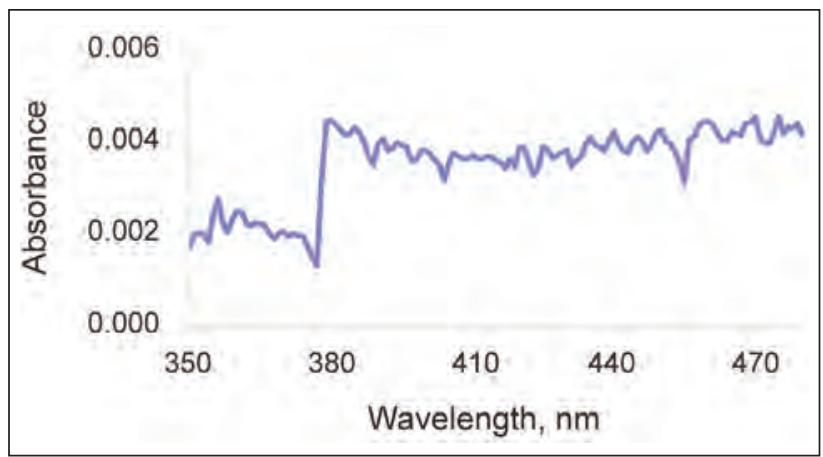

Fig. 1. UV-VIS spectrum for acetic anhydride

\section{RESULTS AND DISCUSSION}

\section{Selectivity (specificity)}

The overlapped UV-VIS spectra of the compounds used for this method, as well as the compounds with formaldehyde-like structure, such as acetaldehyde, are represented in figures 1,2 and 3 . These measurements were of great importance, as they have been used to prove that these substances do not interfere with the formaldehyde determination and that the method is selective.

\section{Limit of detection (LOD) and limit of quantification (LOQ)}

The values of LOD and LOQ are presented in table 1. These values indicate the suitability of the developed method for detection and quantification of formaldehyde at low levels.

\section{Working range and method linearity}

The data has been listed in table 2 . The values of the analyzed samples are very close to the known concentrations and the correlation coefficient is 0.99996 , therefore the chosen working range is suitable for the determination of formaldehyde in a concentration range between $0.15 \mathrm{mg} / \mathrm{l}-6.0 \mathrm{mg} / \mathrm{l}$.

By performing the calibration curve, a correlation coefficient of 0.999977 was obtained, which demonstrates excellent linearity in the $0.15 \mathrm{mg} / \mathrm{l}-6.00 \mathrm{mg} / \mathrm{l}$ concentration range, corresponding to $15 \mathrm{mg} / \mathrm{Kg}-$ $600 \mathrm{mg} / \mathrm{Kg} \mathrm{CH} \mathrm{CH}_{2} \mathrm{O} / \mathrm{g}$ of fabric. The data is listed in table 3.

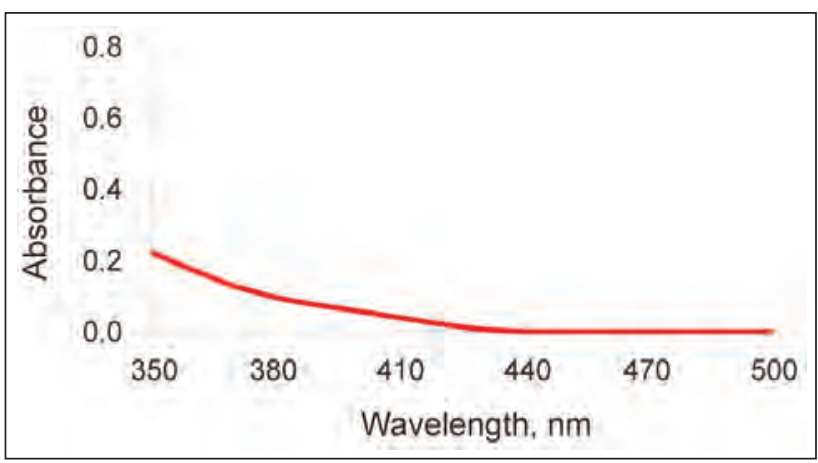

Fig. 2. UV-VIS spectrum for acetaldehyde

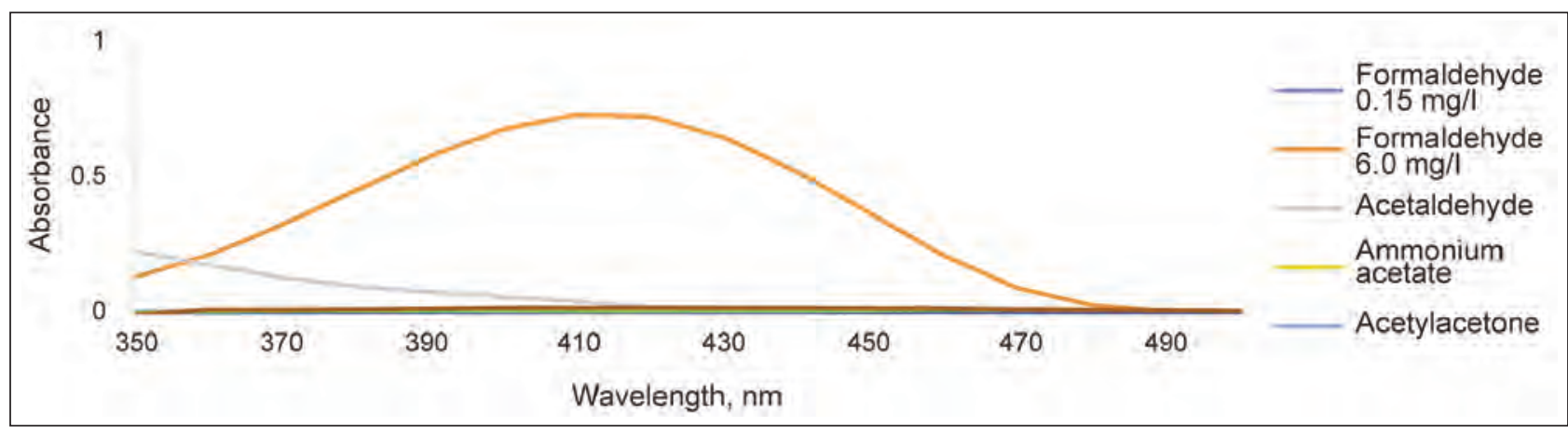

Fig. 3. Overlapped UV-VIS spectra of the compounds used for the current method, as well as the compounds with formaldehyde-like structure (acetaldehyde) 


\begin{tabular}{|c|c|c|c|c|c|c|c|c|c|c|}
\hline \multicolumn{11}{|c|}{ RESULTS FOR LOD AND LOQ MEASUREMENTS } \\
\hline $\begin{array}{c}\text { Blank - theoretical } \\
\text { concentration } 0(\mathrm{mg} / \mathrm{l})\end{array}$ & 1 & 2 & 3 & 4 & 5 & 6 & 7 & 8 & 9 & 10 \\
\hline Mean values $(\mathrm{mg} / \mathrm{l})$ & 0.0768 & 0.0554 & 0.0415 & 0.0480 & 0.0627 & 0.0558 & 0.0499 & 0.0807 & 0.0597 & 0.0656 \\
\hline Standard deviation $=\mathrm{S}_{0}$ & \multicolumn{10}{|c|}{0.0039} \\
\hline $\operatorname{LOD}\left(3 \times \mathrm{S}_{0}\right)$ & \multicolumn{10}{|c|}{0.0117} \\
\hline $\mathrm{LOQ}\left(10 \times \mathrm{S}_{0}\right)$ & \multicolumn{10}{|c|}{0.0390} \\
\hline
\end{tabular}

\begin{tabular}{|c|c|c|c|c|c|c|}
\hline \multicolumn{7}{|c|}{ CONCENTRATION VALUES CORRESPONDING TO THE 8 STANDARD SOLUTIONS } \\
\hline $\begin{array}{c}\text { Known } \\
\text { concentrations } x_{i} \\
(\mathrm{mg} / \mathrm{l})\end{array}$ & $\begin{array}{c}y_{i} \text { for the read } \\
\text { concentrations } \\
(\mathrm{mg} / \mathrm{l})\end{array}$ & $\begin{array}{c}\overline{x i} \\
(m g / l)\end{array}$ & $\begin{array}{c}\overline{y i} \\
(\mathrm{mg} / \mathrm{l})\end{array}$ & b slope & a intercept & $\begin{array}{c}\text { Pearson } \\
\text { coefficient } \rho\end{array}$ \\
\hline $\begin{array}{c}0.00 \\
\text { (blank sample) }\end{array}$ & 0.0348 & \multirow{9}{*}{2.0500} & \multirow{9}{*}{2.0524} & \multirow{9}{*}{0.9989} & \multirow{9}{*}{0.0047} & \multirow{9}{*}{1.0000} \\
\hline 0.1500 & 0.1587 & & & & & \\
\hline 0.3000 & 0.3072 & & & & & \\
\hline 0.7500 & 0.7457 & & & & & \\
\hline 1.5000 & 1.4768 & & & & & \\
\hline 2.2500 & 2.2367 & & & & & \\
\hline 3.0000 & 2.9856 & & & & & \\
\hline 4.5000 & 4.5302 & & & & & \\
\hline 6.0000 & 5.9963 & & & & & \\
\hline
\end{tabular}

\begin{tabular}{|c|c|c|c|}
\hline \multicolumn{3}{|c|}{ CONCENTRATION VALUES CORRESPONDING TO THE CALIBRATION CURVE } \\
\hline Level of concentration & Theoretical value & Measured value & Correlation coefficient $\mathbf{R}^{\mathbf{2}}$ \\
\hline 1 & 0.1275 & 0.1412 & \\
\hline 2 & 0.3000 & 0.2931 & \multirow{2}{*}{0.999977} \\
\hline 3 & 0.7500 & 0.7368 & \\
\hline 4 & 1.5000 & 1.4902 & \\
\hline 5 & 2.2500 & 2.2709 & \\
\hline 6 & 3.0000 & 2.9841 & \\
\hline 8 & 4.5000 & 4.5216 & 6.8896 \\
\hline
\end{tabular}

\section{Analytical}

\section{sensitivity}

The values of the obtained concentrations according to the measured absorbance of the solutions are listed in table 4. Based on these values, the method has been proven to have analytical sensitivity for the determination of formaldehyde.

\begin{tabular}{|c|c|c|c|c|c|c|}
\hline \multicolumn{7}{|c|}{ CONCENTRATION VALUES CORRESPONDING TO THE CALIBRATION CURVE } \\
\hline \multirow{2}{*}{$\begin{array}{c}\text { Specified } \\
\text { (mg/l) }\end{array}$} & \multirow{2}{*}{$\begin{array}{c}\text { Calculated } \\
(\mathrm{mg} / \mathrm{l})\end{array}$} & \multirow{2}{*}{$\begin{array}{c}\text { Residual } \\
\text { (mg/l) }\end{array}$} & \multicolumn{2}{|c|}{$\begin{array}{l}\text { Calibration } \\
\text { coefficient }\end{array}$} & \multirow{2}{*}{$\begin{array}{l}\text { Specified } \\
\text { correlation } \\
\text { coefficient }\end{array}$} & \multirow{2}{*}{$\begin{array}{l}\text { Calculated } \\
\text { correlation } \\
\text { coefficient }\end{array}$} \\
\hline & & & a & b & & \\
\hline 0.1500 & 0.1613 & -0.0113 & \multirow{8}{*}{-0.0046} & \multirow{8}{*}{-0.1395} & \multirow{8}{*}{0.9800} & \multirow{8}{*}{0.9999} \\
\hline 0.3000 & 0.3068 & -0.0068 & & & & \\
\hline 0.7500 & 0.7322 & 0.0178 & & & & \\
\hline 1.5000 & 1.4923 & 0.0077 & & & & \\
\hline 2.2500 & 2.2683 & -0.0183 & & & & \\
\hline 3.0000 & 2.9820 & 0.0180 & & & & \\
\hline 4.5000 & 4.5053 & -0.0053 & & & & \\
\hline 6.0000 & 6.0016 & -0.0016 & & & & \\
\hline
\end{tabular}




\section{Precision (repeatability and reproducibility)}

The results are presented in table 5 .

The RSDR values will be maximum 35\% (table 6).

\section{Recovery}

For the measurements performed on the unfortified standard solution, the average value obtained was 0.2986 , for the fortified standard solution the average value obtained was 2.3788 and for the fortified sample the average value obtained was 1.2174 . $\mathrm{R} \%=$
$100 \times \mathrm{c}^{\prime} / \mathrm{c} 3$ - were c3' is the theoretical concentration of the fortified sample and c3 - the average of the read fortified concentrations. The recovery is $\mathrm{R} \%=89.80 \%$, which is in the acceped range, proving that the method is suitable for the determination of formaldehyde.

\section{Method robustness}

The effect of each modification of the working conditions on the measurement results is represented in table 7 .

Table 5

\begin{tabular}{|c|c|c|c|c|c|c|}
\hline \multicolumn{7}{|c|}{ RESULTS FOR REPEATABILITY CALCULATION } \\
\hline $\begin{array}{c}\text { Theoretical } \\
\text { concentration } \\
\text { (mg/l) }\end{array}$ & $\begin{array}{c}\text { Read } \\
\text { concentration } \\
(\mathrm{mg} / \mathrm{l})\end{array}$ & $\begin{array}{c}\text { Average } \\
\text { concentration } \\
(\mathrm{mg} / \mathrm{l})\end{array}$ & $\begin{array}{c}\text { Repeatability } \\
\text { standard } \\
\text { deviation Sr } \\
\text { (mg/l) }\end{array}$ & $\begin{array}{c}\text { Repeatability } \\
\text { limit } r \\
(\mathrm{mg} / \mathrm{l}) \\
r=2.8 \mathrm{Sr}\end{array}$ & $\begin{array}{c}\text { Repeatability } \\
\text { relative standard } \\
\text { deviation }(\%) \\
\text { RSDr }=100 \times(\mathrm{Sr} / \mathrm{x})\end{array}$ & $\begin{array}{c}\text { Reproducibility } \\
\text { limit } \\
\mathrm{R}=1.6 \times \mathrm{r} \\
(\mathrm{mg} / \mathrm{l})\end{array}$ \\
\hline \multirow{10}{*}{2.5000} & 2.2018 & \multirow{10}{*}{2.2075} & \multirow{10}{*}{0.0025} & \multirow{10}{*}{0.0069} & \multirow{10}{*}{0.1100} & \multirow{10}{*}{0.0110} \\
\hline & 2.2065 & & & & & \\
\hline & 2.2057 & & & & & \\
\hline & 2.2063 & & & & & \\
\hline & 2.2082 & & & & & \\
\hline & 2.2092 & & & & & \\
\hline & 2.2090 & & & & & \\
\hline & 2.2090 & & & & & \\
\hline & 2.2092 & & & & & \\
\hline & 2.2098 & & & & & \\
\hline
\end{tabular}

Table 6

\begin{tabular}{|c|c|c|c|c|c|}
\hline \multicolumn{6}{|c|}{ RESULTS FOR REPRODUCIBILITY CALCULATION } \\
\hline $\begin{array}{l}\text { Theoretical } \\
\text { concentration } \\
\text { (mg/l) }\end{array}$ & $\begin{array}{c}\text { Average } \\
\text { concentration } \\
\text { (mg/l) }\end{array}$ & $\begin{array}{c}\text { Reproducibility } \\
\text { standard deviation } \\
\text { SR (mg/l) }\end{array}$ & $\begin{array}{l}\text { Reproducibility } \\
\text { limit } r \text { (mg/l) } \\
r=2.8 \mathrm{SR}\end{array}$ & $\begin{array}{l}\text { Reproducibility relative } \\
\text { standard deviation }(\%) \\
\text { RSDR }=100 \times(\mathrm{SR} / \mathrm{x})\end{array}$ & $\begin{array}{l}\text { Reproducibility } \\
\text { limit } R=1.6 \times r \\
(\mathrm{mg} / \mathrm{l})\end{array}$ \\
\hline 3 (First analyst) & \multirow{2}{*}{3.0489} & \multirow{2}{*}{0.0175} & \multirow{2}{*}{0.0489} & \multirow{2}{*}{0.0790} & \multirow{2}{*}{0.5735} \\
\hline 3 (Second analyst) & & & & & \\
\hline
\end{tabular}

Table 7

\begin{tabular}{|c|c|c|c|}
\hline \multicolumn{4}{|c|}{ RESULTS FOR ROBUSTNESS AFTER CHANGING THE WAVELENGTH VALUE } \\
\hline $\begin{array}{l}\text { Wavelength } \\
\quad(\mathrm{nm})\end{array}$ & $\begin{array}{l}\text { Formaldehyde standard } \\
\text { solution quantity (mg/l) }\end{array}$ & $\begin{array}{c}\text { Standard } \\
\text { deviation s }\end{array}$ & $\begin{array}{l}\text { Formaldehyde quantity detected }(\mathrm{mg} / \mathrm{l}) \\
\qquad \mathrm{RSD}=\mathrm{s} / \text { Xmedium }\end{array}$ \\
\hline \multirow{4}{*}{405} & \multirow{4}{*}{2.25} & \multirow{4}{*}{0.0017} & 2.2605 \\
\hline & & & 2.2625 Xmedium $=2.2619$ \\
\hline & & & 2.2627 \\
\hline & & & $2.2619 \mathrm{mg} / \mathrm{l} \pm 0.0761 \%$ formaldehyde \\
\hline \multirow{4}{*}{410} & \multirow{4}{*}{2.25} & \multirow{4}{*}{0.0015} & 2.2583 \\
\hline & & & 2.2599 Xmedium $=2.2595$ \\
\hline & & & 2.2603 \\
\hline & & & $2.2664 \mathrm{mg} / \mathrm{l} \pm 0.0662 \%$ formaldehyde \\
\hline \multirow{4}{*}{415} & \multirow{4}{*}{2.25} & \multirow{4}{*}{0.0015} & 2.2667 \\
\hline & & & 2.2673 Xmedium $=2.2664$ \\
\hline & & & 2.2652 \\
\hline & & & $2.2664 \mathrm{mg} / \mathrm{l} \pm 0.0675 \%$ formaldehyde \\
\hline
\end{tabular}




\section{Proficiency test}

The performance of the laboratory was evaluated according to "z-scores":

- $|z| \leq 2$ : result: correct (color code: green);

- $2<|z| \leq 3$ : result: questionable (warning signal color code: orange);

- $|z|>3$ : result: not satisfactory (action signal - color code: red).

The comparative results for the z-score obtained have been represented in figure 4 . The concentration values $(\mathrm{mg} / \mathrm{kg})$ attained by each laboratory have been presented in figure 5 . The leter $O$ was assigned to our laboratory and the $z$ score obtained was -0.38 .
Confirmation of the instrument performance

An example of the holmium oxide verification is shown in table 8.

The difference between the theoretical values and the measured values is less than $1 \mathrm{~nm}$, which is an indicator of the proper functioning of the equipment. Also, before each set of samples, 2 solutions from the calibration curve $(0.1600 \mathrm{mg} / \mathrm{l}$ and $0.7500 \mathrm{mg} / \mathrm{l})$ were analyzed. The values must range between the values from table 9 .

\section{Uncertainty determination}

The calculated value of the uncertainty for this method is $8.7 \%$.

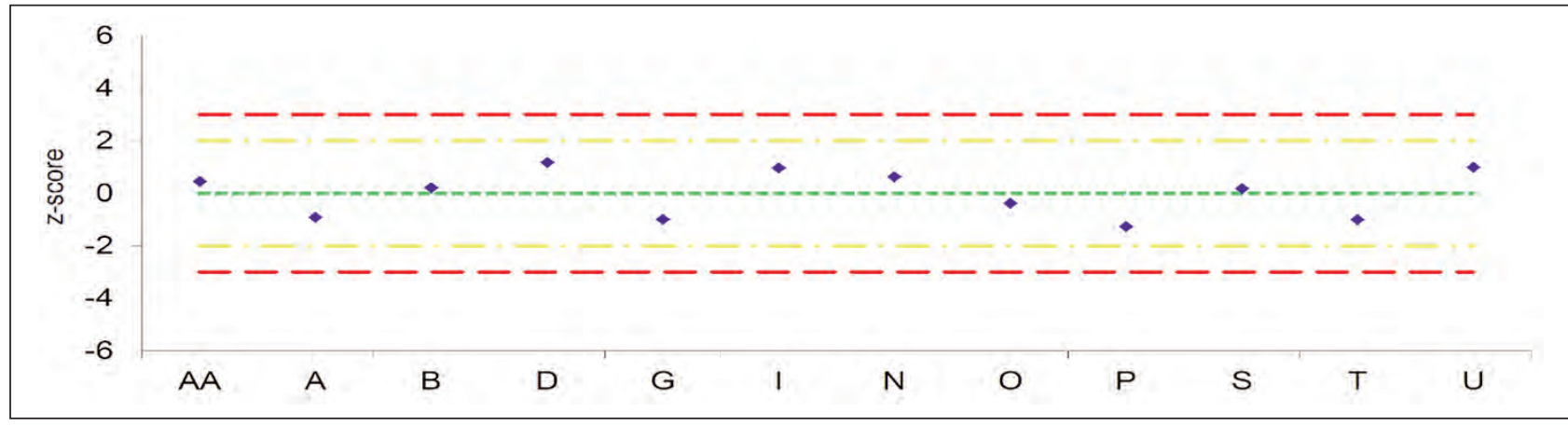

Fig. 4. Z-score value for each laboratory

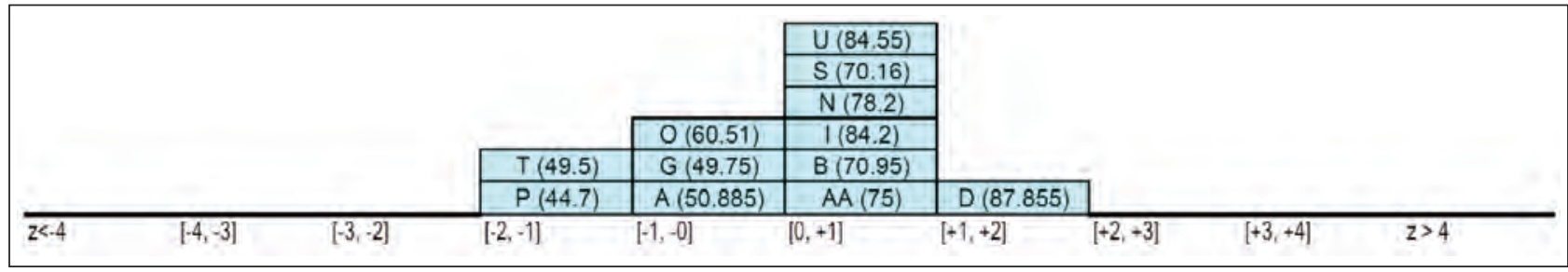

Fig. 5. Concentration in $\mathrm{mg} / \mathrm{kg}$ and z-score for each laboratory

Table 8

\begin{tabular}{|c|c|c|c|c|c|c|c|c|c|c|c|c|c|c|c|}
\hline \multicolumn{16}{|c|}{ RESULTS FOR HOLMIUM OXIDE MEASUREMENT } \\
\hline $\begin{array}{l}\text { Values } \\
\text { of wave- }\end{array}$ & $\begin{array}{c}\text { Spectral } \\
\text { slot }\end{array}$ & \multicolumn{14}{|c|}{ The corresponding wavelength T\% minimum (nm) } \\
\hline $\begin{array}{c}\text { Theoretical } \\
\text { values }\end{array}$ & \multirow{2}{*}{$2 \mathrm{~nm}$} & 241.10 & 250.00 & 278.10 & 287.50 & 333.50 & 345.40 & 361.10 & 385.80 & 416.60 & 451.30 & 467.90 & 485.20 & 536.90 & 640.80 \\
\hline $\begin{array}{c}\text { Measured } \\
\text { values }\end{array}$ & & 241.22 & 250.11 & 278.18 & 287.61 & 333.59 & 345.55 & 361.27 & 385.96 & 416.74 & 451.45 & 468.07 & 485.42 & 537.06 & 640.99 \\
\hline \multicolumn{2}{|c|}{ Confidence interval } & \multicolumn{14}{|c|}{$95 \%$ Confidence interval $\pm 1 \mathrm{~nm}$} \\
\hline
\end{tabular}

RESULTS FOR THE INTERMEDIARY VERIFICATION WITH TWO SOLUTIONS FORM THE CALIBRATION CURVE

\begin{tabular}{|c|c|c|c|c|c|c|}
\hline Result & \multicolumn{2}{|c|}{ Correct result } & \multicolumn{2}{c|}{ Acceptable result } & \multicolumn{2}{c|}{ Acceptable result } \\
\hline $\mathbf{x}$ & $\mathbf{x}-\mathbf{0 . 0 0 2 3 7 8}$ & $\mathbf{x}+\mathbf{0 . 0 0 2 3 7 8}$ & $\mathbf{x}-\mathbf{0 . 0 0 3 5 6 7}$ & $\mathbf{x}-\mathbf{0 . 0 0 2 3 7 8}$ & $\mathbf{x + \mathbf { 0 . 0 0 2 3 7 8 }}$ & $\mathbf{x}+\mathbf{0 . 0 0 3 5 6 7}$ \\
\hline 0.1697 & 0.1673 & 0.1721 & 0.1661 & 0.1673 & 0.1721 & 0.1733 \\
\hline $\mathbf{x}$ & $\mathbf{x}-\mathbf{0 . 0 0 1 8 6 6}$ & $\mathbf{x + 0 . 0 0 1 8 6 6}$ & $\mathbf{x}-\mathbf{0 . 0 0 2 7 9 9}$ & $\mathbf{x}-\mathbf{0 . 0 0 1 8 6 6}$ & $\mathbf{x}+\mathbf{0 . 0 0 1 8 6 6}$ & $\mathbf{x + 0 . 0 0 2 7 9 9}$ \\
\hline 0.7451 & 0.7432 & 0.747 & 0.7423 & 0.7432 & 0.747 & 0.7479 \\
\hline
\end{tabular}




\section{CONCLUSIONS}

A method for the determination of the free and hydrolysed formaldehyde from textile materials has been validated. The performance parameters (selectivity, limit of detection, limit of quantification, working range and method linearity, sensitivity, precision, recovery, robustness) of the method have been evaluated and they indicate that this method is precise and reliable. The method is accredited by RENAR, the Romanian Organism for the Accreditation of Laboratories.

\section{ACKNOWLEDGEMENTS}

This work was elaborated through Nucleu Program, conducted with $\mathrm{MCl}$ support, project no. 4N/2019/PN 191705 01 . The publication fee of the paper is funded by the Ministry of Research and Innovation within Program 1 Development of the national RD system, Subprogram 1.2 Institutional Performance - RDI excellence funding projects, Contract no. 6PFE/2018.

\section{REFERENCES}

[1] Kawakami, Y., Maruo, Y.Y., Nakagawa, T., Saito, H., A screening method for detecting formaldehyde emitted from textile products, In: Measurement: Journal of the International Measurement Confederation, 2015, 62, 41-46

[2] Schreier, T.M., Rach, J.J. \& Howe, G.E., Efficacy of formalin, hydrogen peroxide, and sodium chloride on fungalinfected rainbow trout eggs, In: Aquaculture, 1996, 140, 323-331

[3] Pietrzak, K., Otlewska, A., Danielewicz, D., Dybka, K., Pangallo, D., Kraková, L., Pu`skárová, A., Mária Bu`cková., Scholtz, V., Durovic, M., Surma-Slusarska, B., Demnerová, K., Gutarowska B., Disinfection of archival documents using thyme essential oil, silver nanoparticles misting and low temperature plasma, In: Journal of Cultural Heritage, 2017, 24, 69-77

[4] Gutarowska, B., Pietrzak, K., Machnowski, W., Milczarek, J.M., Historical textiles - a review of microbial deterioration analysis and disinfection methods, In: Textile Research Journal, 2017, 87, 2388-2406

[5] IARC Press Release 153, 2004, Available at: http://www.iarc.fr/ENG/Press_Releases/archives/pr153a.html [Accessed October 2019]

[6] NICNAS, Formaldehyde in Clothing and Textiles FactSheet, In: Australian National Industrial Chemicals Notification and Assessment Scheme, 2013

[7] Piccinini, P., Senaldi, C., Summa, C., European survey on the release of formaldehyde from textiles, Conducted within the CHEM TEST project on behalf of DG SANCO, 2007, ISBN 978-92-79-05215-6

[8] Sáenz, M., Alvarado, J., Pena-Pereira, F., Senra-Ferreiro, S., Lavilla, I., Bendicho, C., Liquid-phase microextraction with in-drop derivatization combined with microvolume fluorospectrometry for free and hydrolyzed formaldehyde determination in textile samples, In: Analytica Chimica Acta, 2011, 687, 50-55

[9] ISO 14184-1: 2011 Textiles - Determination of formaldehyde - Part 1: Free and hydrolysed formaldehyde (water extraction method)

[10] Decision no. 350/2014 laying down the ecological criteria for the award of the EU Ecolabel for textiles [notified with C(2014) 3677 number]; Celex number: 32014D0350, Published in Official Journal of the European Union no. 174 of 13.06 .2014

[11] Tanase, I.G., Pana, A., Radu, G. L., Buleandra, M., Validarea metodelor analitice, Ed. Printech, 2007

[12] ISO 11843, Capability of detection, Geneva (several parts)

[13] European Commission, Commission Decision 96/23/EC on measures to monitor certain substances and residues thereof in live animals and animal products and repealind Directives 85/258/EC and Decisions 89/187/EC and 91/664/EC, Off. J. Eur. Commun., 1, 125, 0010-0032, 23.05.1996

[14] ICH-Q2A, Guideline for Industry: Text on Validation of Analytical Procedures, 1995 Available at: http://www.fda.gov/ cder/guidance/index.htm [Accessed October 2019]

[15] Thompson, M., Ellison, S.L.R., Wood, R., Harmonized guidelines for single-laboratory validation of methods of analysis, In: Pure and Applied Chemistry, 2002, 74, 5, 835-855

Authors:

LUCIA OANA SECĂREANU ${ }^{1}$, CORNELIA-ELENA MITRAN ${ }^{1,2}$, IRINA-MARIANA SĂNDULACHE ${ }^{1,2}$, MIHAELA-CRISTINA LITEE ${ }^{1,2}$, ELENA PERDUM ${ }^{1}$, OVIDIU-GEORGE IORDACHE ${ }^{1}$

${ }^{1}$ National Research and Development Institute for Textiles and Leather - INCDTP, Lucretiu Patrascanu Street, no. 16, 030508, Bucharest, Romanaia e-mail: office@incdtp.ro

2Politehnica University of Bucharest, 1-7 Gheorghe Polizu Street, 011061, Bucharest, Romania e-mail: secretariat@chimie.upb.ro

Corresponding author:

CORNELIA-ELENA MITRAN

e-mail: cornelia.mitran@incdtp.ro 


\title{
Investigation of surface defects and apparel manufacturing efficiency of fabrics woven from recycled cotton and blends
}

\author{
DOI: $10.35530 / I T .071 .03 .1639$
}

KALKANCI MIHRIBAN

\section{ABSTRACT - REZUMAT}

\section{Investigation of surface defects and apparel manufacturing efficiency of fabrics woven from recycled cotton and blends}

For a sustainable life, new strategies have come to the forefront relating to design, production and recycling processes in textiles and apparel manufacturing industries. In this study, woven fabrics consisting of weft threads from recycled cotton fiber, original cotton fiber and original polyester fiber (35\%/65\% polyester/recycled cotton, 35\%/65\% polyester/original cotton) were made to order in a textile firm and have been investgated in terms of surface defects and apparel manufacturing efficiency. The types and numbers of defects obtained during inspection were recorded and evaluated by using Pareto analysis. The percentage of surface/fabric defective products in all defects is $78.57 \%$ for $35 \% / 65 \%$ polyester-recycled cotton fabrics and $69.09 \%$ for that in $35 \% / 65 \%$ polyester-original cotton fabrics. The percentage of second quality products at the end of apparel manufacturing is $4.9 \%$ for recycled cotton fabric products and $2.75 \%$ for original cotton fabrics.

Keywords: recycled fabric, fabric quality, second quality, wastage, apparel manufacturing efficiency

\section{Analiza defectelor de suprafață și a eficienței producției de îmbrăcăminte pentru țesăturile din bumbac reciclat și în amestec}

Pentru o dezvoltare durabilă, noi strategii sunt implementate privind procesele de proiectare, producție și reciclare în industria textilă și de îmbracăminte. În acest studiu, țesăturile realizate din bumbac reciclat, bumbac original și poliester original (35\%/65\% poliester/bumbac reciclat, 35\%/65\% poliester/bumbac original) au fost utilizate într-o companie producătoare de îmbrăcăminte și au fost analizate, în ceea ce privește defectele de suprafață și eficiența producției. Tipurile și numărul de defecte identificate în timpul inspecției au fost înregistrate și evaluate utilizând analiza Pareto. Procentul de produse cu defecte de suprafață din totalul defectelor este de $78,57 \%$, pentru țesăturile din $35 \% / 65 \%$ poliester/bumbac reciclat și 69,09\% pentru țesăturile din 35\%/65\% polyester/bumbac original. Procentul de produse de calitatea a doua, la sfârșitul producției de îmbrăcăminte este de 4,9\% pentru produsele din țesături din bumbac reciclat și de 2,75\% pentru țesăturile din bumbac original.

Cuvinte-cheie: țesătură reciclată, calitatea țesăturii, calitatea a doua, deșeuri, eficiența producției de îmbrăcăminte

\section{INTRODUCTION}

The recycling issue has come into prominence due to exhaustion of natural sources as well as the fact that textiles is an industry that is harmful for the environment. Other environmentally-friendly applications in textiles are carried out with strategies including "clean production", "recover/reuse", "reduction of waste in the first place", "product modification", "recycle", "energy recovery", and "waste utilization". Because of great production volumes, approximately one million tons of waste are generated in Turkey by the textile industry each year. If total recovery would be possible, this would be equal to $17 \%$ of annual national unginned cotton [2]. It is quite difficult to investigate recycling in textile production issue under one title because raw material, machinery, energy types and costs, environmental interactions during processes and recyclability of products are not the same [3]. Recycling is mostly carried out during spinning. Open end spinning utilizes recycled fibers in great ratios, as the open-end rotor spinning method allows use of shorter fibers compared to ring spinning [4].

However, the wastes that are generated in the end of apparel manufacturing processes are fabric roll start and end pieces (approximately 15\% of whole fabric), spread cutting leftovers, and defective fabric pieces [3]. The wastage ratios of carded yarn production is $5.5-10.5 \%$, combed yarn production is $12 \%$, and this ratio approaches $23 \%$ at fabric and apparel manufacturing steps [5]. Significant raw material recovery can be achieved, if the wastes of the apparel manufacturing and spinning are utilized.

There are different methods of recycling including product recovery, chemical recovery and thermal recovery [6]. The structural and mechanical properties of fabrics produced from textile wastes, and their utilization areas [7-11], the utilization potential of polyester/cotton blend fabrics in composite materials [12] and production possibilities and production parameters of recycled yarns [13-18] have been the subjects of recent studies. However, studies relating 


\begin{tabular}{|c|c|c|c|c|c|c|c|}
\hline \multicolumn{8}{|c|}{ FABRIC PROPERTIES } \\
\hline \multirow{2}{*}{$\begin{array}{c}\text { Order } \\
\text { number }\end{array}$} & \multirow{2}{*}{$\begin{array}{l}\text { Weft thread } \\
\text { raw material }\end{array}$} & \multirow{2}{*}{$\begin{array}{c}\text { Weft thread } \\
\mathrm{Ne}\end{array}$} & \multicolumn{2}{|c|}{ Density (thread/cm) } & \multirow{2}{*}{$\begin{array}{c}\text { Weight } \\
\left(\mathrm{g} / \mathrm{m}^{2}\right)\end{array}$} & \multirow{2}{*}{$\begin{array}{c}\text { Roll } \\
\text { number }\end{array}$} & \multirow{2}{*}{$\begin{array}{c}\text { Total } \\
\text { (m) }\end{array}$} \\
\hline & & & Warp & Weft & & & \\
\hline 1 & $35 \%$ PES-65\% r-Cotton & $20 / 1$ & 30 & 25 & 100 & 9 & 2372 \\
\hline 2 & $35 \%$ PES-65\% Cotton & $20 / 1$ & 30 & 25 & 100 & 8 & 2360 \\
\hline
\end{tabular}

to the defects of fabrics produced from recycled fibers and their effect on the apparel manufacturing are not sufficient.

Defect formation during woven fabric production is inevitable regardless of the raw material. In the studies which have been conducted in toweling fabric [19] and apparel fabric [20,21] weaving factories in order for determination and statistical evaluation of fabric defects, it was reported that $95 \%$ of problems which occur due to fabric defects can be solved by means of seven technical methods. These methods are flow chart, check sheet, cause effect diagram, histogram, scatter diagram, and control cards [22-23]. Woven fabric defects are deviations, which occur regionally, affect fabric appearance, change fabric structure and cause special changes in regional limitation [24]. Fabric defects have been defined by Turkish Standards Institute as "defects in fabrics which are caused by the yarn, auxiliary material, labor, machinery, equipment or working method, and can be seen and evaluated with eye and impair fabric appearance" [25].

In this study, it was aimed to determine and define defects that can be encountered on fabrics in a factory, which produces shirting fabrics from yarns of recycled cotton fibers and their blends (regenerated yarns, as known in the industry). The most common defects were investigated through Pareto analysis among statistical process control methods. Following, the efficiency of two fabrics made to order were compared by investigating defective pieces generated during sorting processes in apparel manufacturing and second-quality product amount formed at the end of production.

\section{MATERIAL and METHOD}

\section{Material}

The study has been carried out at a factory of yarnweaving (315 weaving machines) in Denizli (Turkey). This study has been conducted in a factory, located in Denizli province, (consisting of spinning and weaving mills), which has 315 weaving machines and produces home textiles (such as bedlinens) -, shirting, trouser and clothing fabrics. In the study, white shirting fabrics (weft threads of $35 / 65 \%$ polyester/recycled cotton and $35 / 65 \%$ polyester/original cotton) produced for two women's shirt orders were investigated. The warp thread was 100-denier polyester yarn for all fabrics which were woven with plain weave repeat. The recycled yarns were produced in the open-end spinning section of the mentioned factory. The recycled fibers were obtained from Uşak province. The length of the polyester staple fiber is $38 \mathrm{~mm}$. In woven fabrics, both weft and warp threads influence the physical and mechanical properties of the fabrics. In the industry, polyester fibers are preferred in blends for avoiding problems that can occur due to recycled yarns. In this study, no changes have been made in warp density and type. On the other hand, only changes to weft threads were made. In table 1 , the density and weight values of fabrics that were produced for orders are shown.

\section{Method}

Woven raw fabrics were investigated manually by using a light board. The controls were carried out on the raw fabric. Pareto analysis, among statistical process control methods, was used for statistical analysis of defect numbers obtained from the fabric inspection.

The defects that are classified in fabric inspection sheets used in the current study can be grouped in three main classes; defects in weft direction, defects in warp direction and other defects. The defects in weft direction are full-width double wefts, half-width double wefts, full-width broken weft, half-width broken weft, stop mark, weft fiber in color, soiledgreased weft, thin-thick weft, excessive weft density. The defects in warp direction are broken warp, excessive warp density, loose-tight warp, warp fiber in color, stained-greased warp, thin thick warp, double warps, missing warp, temple mark; and other defects include hole/tear/burst, slub, bad selvedge, knot, batch difference, and ripple effect.

All fabrics are received to the factory in two batches and in white color. Shirts were cut and sewn in the apparel supplier of the factory in Denizli. Apparel manufacturing processes have been carried out and then apparel manufacturing efficiency, and second quality ratios were determined.

\section{FINDINGS AND DISCUSSION}

\section{Woven fabric defect numbers and Pareto} analysis

In table 2, the width, length and grams per square information of fabrics produced for the orders are shown. According to this, 9 rolls from the 35\% PES $65 \%$ r-Cotton fabric, and 8 rolls from the 35\% PES $65 \%$ Cotton fabric were investigated.

In total, 2372 meters of $35 \%$ PES - 65\% r-Cotton and 2360 meters of $35 \%$ PES and $65 \%$ Cotton fabrics woven for orders were investigated and the obtained 


\begin{tabular}{|c|c|c|c|c|c|c|c|c|c|}
\hline \multicolumn{10}{|c|}{ STRUCTURAL PROPERTIES OF THE INVESTIGATED FABRICS } \\
\hline \multicolumn{10}{|c|}{$35 \%$ PES-65\% r-Cotton fabrics } \\
\hline Fabric roll number & 1 & 2 & 3 & 4 & 5 & 6 & 7 & 8 & 9 \\
\hline Fabric roll length $(\mathrm{m})$ & 347 & 248 & 150 & 222 & 373 & 286 & 276 & 175 & 295 \\
\hline Fabric roll width (cm) & 159 & 160 & 161 & 159.5 & 160 & 160 & 161 & 160 & 160 \\
\hline Weight $\left(\mathrm{g} / \mathrm{m}^{2}\right)$ & 103 & 110 & 109 & 105 & 101 & 100 & 102 & 109 & 105 \\
\hline \multicolumn{10}{|c|}{$35 \%$ PES $-65 \%$ Cotton fabrics } \\
\hline Fabric roll number & 1 & 2 & 3 & 4 & 5 & 6 & 7 & \multicolumn{2}{|c|}{8} \\
\hline Fabric roll length $(\mathrm{m})$ & 228 & 293 & 305 & 345 & 380 & 253 & 246 & \multicolumn{2}{|c|}{310} \\
\hline Fabric roll width $(\mathrm{cm})$ & 160 & 159.5 & 160 & 160 & 159.5 & 160 & 160 & \multicolumn{2}{|c|}{161} \\
\hline Weight $\left(\mathrm{g} / \mathrm{m}^{2}\right)$ & 102 & 100 & 103 & 101 & 101 & 100 & 109 & \multicolumn{2}{|c|}{104} \\
\hline
\end{tabular}

fabric defects were recorded in inspection sheets. The defects in the outermost 3 centimeters of fabric width were ignored. In case there are more than one defects in a running meter of the fabric, the defect with the highest penalty points was recorded into the control card. Pareto analysis, among statistical process control methods, was used for the statistical analysis of the defect numbers obtained from the fabric inspection.

The numbers of defects obtained from $35 \%-65 \%$ $r$-Cotton fabric rolls are given in table 3. Accordingly, the total number of defects obtained from 9 rolls is 293 . The numbers of defects obtained from $35 \%-65 \%$ Cotton fabric rolls are given in table 4 . Accordingly,

Table 3

\begin{tabular}{|c|c|c|c|c|c|c|c|c|c|}
\hline \multicolumn{10}{|c|}{ NUMBERS OF DEFECTS FOUND ON 35\% PES-65\% R-COTTON FABRIC ROLLS } \\
\hline Defect name & 1st roll & 2nd roll & 3rd roll & 4th roll & 5th roll & 6th roll & 7th roll & 8th roll & 9th roll \\
\hline Full-width double wefts & 5 & 3 & 2 & 2 & 4 & 2 & 6 & 1 & 3 \\
\hline Double wefts half-width or less & 3 & & 3 & 3 & 4 & 2 & 2 & 2 & 2 \\
\hline Full-width broken weft & & & & & 1 & & & & \\
\hline Half-width broken weft & 7 & 3 & 4 & 3 & 7 & 8 & 7 & 8 & 8 \\
\hline Stop mark & 5 & 4 & 2 & 4 & 5 & 3 & 6 & 2 & 4 \\
\hline Fiber in color & 3 & & & 1 & 4 & & 3 & & 1 \\
\hline Soiled-greased weft & & & 2 & & 3 & & 5 & & \\
\hline Thin-thick weft & 4 & 3 & & 3 & 5 & & & 3 & \\
\hline Excessive weft density & & & & & & 2 & & & \\
\hline Broken warp & 4 & 4 & 3 & 6 & 5 & 4 & 4 & 2 & 1 \\
\hline Excessive warp density & & & & 1 & & & 1 & 1 & 1 \\
\hline Tight-loose warp & & & & & 2 & & & & \\
\hline Drawing-in defect & & & & 1 & & & & 1 & \\
\hline Lattice & & & 1 & & & & & & \\
\hline Warp fiber in color & 1 & & & & & & & & \\
\hline Soiled-greased warp & & 1 & 1 & 2 & 3 & 1 & & 3 & \\
\hline Thin thick warp & & & & & & 1 & & & \\
\hline Double warps & & & & & & 1 & & & \\
\hline Missing warp & & & & & & 1 & & & \\
\hline Temple mark & & & & & 1 & & & & \\
\hline Hole-tear-burst & & & 1 & & & & & & \\
\hline Slub & & 1 & & 4 & 6 & & 1 & 4 & 1 \\
\hline Bad selvedge & 1 & 3 & & & 1 & 4 & 4 & & 4 \\
\hline Knot & & & & 3 & 1 & 1 & 1 & 3 & 1 \\
\hline Soil grease stain & & 2 & & & 3 & & 2 & & 1 \\
\hline Number of defects in the roll & 33 & 24 & 19 & 33 & 55 & 30 & 42 & 30 & 27 \\
\hline Total defect number & & & & & 293 & & & & \\
\hline
\end{tabular}




\begin{tabular}{|c|c|c|c|c|c|c|c|c|}
\hline \multicolumn{9}{|c|}{ NUMBERS OF DEFECTS FOUND ON 35\% PES-65\% COTTON FABRIC ROLLS } \\
\hline Defect name & 1st roll & 2nd roll & 3rd roll & 4th roll & 5th roll & 6th roll & 7th roll & 8th roll \\
\hline Full-width double wefts & 1 & 1 & 2 & 2 & 3 & 5 & 1 & 2 \\
\hline Double wefts half-width or less & & 2 & 2 & 3 & 4 & 2 & 2 & 3 \\
\hline Full-width broken weft & & 1 & & & 1 & & & \\
\hline Half-width broken weft & 1 & 2 & 1 & 1 & 1 & 1 & 3 & 2 \\
\hline Stop mark & 4 & 4 & 2 & 4 & 5 & 3 & 2 & 2 \\
\hline \multicolumn{9}{|l|}{ Fiber in color } \\
\hline Soiled-greased weft & & & & & 3 & 1 & & 2 \\
\hline Thin-thick weft & 1 & & & 3 & 2 & & 3 & \\
\hline Excessive weft density & & & 1 & & & & & \\
\hline Broken warp & 4 & 2 & 1 & 8 & 5 & 4 & 1 & 3 \\
\hline Excessive warp density & & 1 & 1 & 1 & & 1 & 1 & \\
\hline Tight-loose warp & & & & 2 & & & & \\
\hline Drawing-in defect & & & & 1 & & & 1 & \\
\hline Lattice & & & & & & & & 1 \\
\hline Warp fiber in color & & & 1 & & & & & \\
\hline Soiled-greased warp & 1 & & & 2 & 4 & & 3 & 1 \\
\hline Thin thick warp & & & & 1 & & & & \\
\hline Double warps & & & 1 & & & & & \\
\hline Missing warp & 1 & & & & & & & \\
\hline Temple mark & & & & & 1 & & & \\
\hline Hole-tear-burst & & & & & & & & 1 \\
\hline Slub & 1 & 2 & 1 & 5 & 7 & 1 & 4 & \\
\hline Bad selvedge & 3 & 4 & 4 & & 1 & 4 & & \\
\hline Knot & & 1 & 1 & 3 & 1 & 1 & 3 & \\
\hline Soil grease stain & 2 & 1 & 1 & & 3 & 2 & & \\
\hline Number of defects in the roll & 19 & 21 & 19 & 36 & 41 & 25 & 24 & 17 \\
\hline Total defect number & & & & & & & & \\
\hline
\end{tabular}

the total number of defects obtained from 8 rolls is 202.

In the defect report sheet, the defects are listed in descending order in terms of their numbers, and defect percentages and cumulative rates are given as in table 5.

Among the 25 woven fabric defects obtained from $35 \%-65 \%$ r-Cotton fabric rolls, the Pareto diagram shown in figure 1 has been arranged in order to determine $80 \%$ of the defects based on data gathered from table 5. In the conducted Pareto analysis, it was seen that half-width broken weft $(18.77 \%)$, stop mark $(11.95 \%)$, broken warp $(11.26 \%)$, full-width weft $(8.42 \%)$, double wefts half width or less $(7.17 \%)$, thin-thick weft $(6.14 \%)$, slub $(5.80 \%)$, bad selvedge $(5.80 \%)$, fiber in color $(4.10 \%)$ which take the highest 9 ranks constitute $80.55 \%$ of all defects.

Among the 25 woven fabric defects obtained from $35 \%$ PES - 65\% Cotton fabric rolls, the Pareto diagram shown in figure 2 has been arranged in order to determine $80 \%$ of the defects based on data gathered from table 5 . In the conducted Pareto analysis, it was seen that broken warp $(13.86 \%)$, stop mark $(12.87 \%)$, slub $(10.40 \%)$, double wefts half-width or less $(8.91 \%)$, full-width double wefts $(8.42 \%)$, bad selvedge $(7.92 \%)$, half-width broken weft $(5.94 \%)$, soiled greased warp $(5.45 \%)$, knot $(4.95 \%)$ which take the highest 9 ranks constitute $78.71 \%$ of all defects.

For the two fabric groups, if the first nine of twentyfive defect types can be avoided, it may be possible to decrease wastage amount by $80 \%$.

When table 5, figures 1 and 2 are investigated, it will be seen that the rankings of defect types are different in 35\% PES-65\% r-Cotton and 35\% - 65\% Cotton fabrics. The half-width broken weft defect, which ranks the first and constitutes $18.77 \%$ of all defects in the $35 \%$ PES-65\% r-Cotton fabric occurred due to the production method of the recycled cotton thread or fiber content. In the original fabrics, half-width broken weft defect descends to the seventh rank with a percent of $5.94 \%$. It is thought that the strength of weft threads decreases due to the fiber quality in the recycled yarns and this leads to weft breaks. Ersoy and Şenol reported in their study, related to yarn production from recycled fibers, that variations in mass per unit length increases based on yarn formation at high rotor speed and; hence, unevenness value 


\begin{tabular}{|c|c|c|c|c|c|c|c|c|}
\hline \multicolumn{9}{|c|}{ DISTRIBUTION OF DEFECTS IN THE FABRICS } \\
\hline \multirow{2}{*}{$\begin{array}{l}\text { Defect } \\
\text { order }\end{array}$} & \multicolumn{4}{|c|}{$35 \%$ PES $-65 \%$ r-Cotton fabrics } & \multicolumn{4}{|c|}{$35 \%$ PES $-65 \%$ Cotton fabrics } \\
\hline & $\begin{array}{l}\text { Defect } \\
\text { name }\end{array}$ & $\begin{array}{l}\text { Number } \\
\text { of defect }\end{array}$ & $\begin{array}{l}\text { Defect } \\
\text { percent }\end{array}$ & $\begin{array}{c}\text { Cumulative } \\
\text { percent }\end{array}$ & $\begin{array}{l}\text { Defect } \\
\text { name }\end{array}$ & $\begin{array}{l}\text { Number } \\
\text { of defect }\end{array}$ & $\begin{array}{l}\text { Defect } \\
\text { percent }\end{array}$ & $\begin{array}{c}\text { Cumulative } \\
\text { percent }\end{array}$ \\
\hline 1 & $\begin{array}{l}\text { Half-width broken } \\
\text { weft }\end{array}$ & 55 & 18.77 & 18.77 & Broken warp & 28 & 13.86 & 13.86 \\
\hline 2 & Stop mark & 35 & 11.95 & 30.72 & Stop mark & 26 & 12.87 & 26.73 \\
\hline 3 & Broken warp & 33 & 11.26 & 41.98 & Slub & 21 & 10.40 & 37.13 \\
\hline 4 & $\begin{array}{l}\text { Full-width double } \\
\text { wefts }\end{array}$ & 28 & 9.56 & 51.54 & $\begin{array}{l}\text { Double wefts } \\
\text { half-width or less }\end{array}$ & 18 & 8.91 & 46.04 \\
\hline 5 & $\begin{array}{l}\text { Double weft half } \\
\text { width or less }\end{array}$ & 21 & 7.17 & 58.7 & $\begin{array}{l}\text { Full-width double } \\
\text { wefts }\end{array}$ & 17 & 8.42 & 54.46 \\
\hline 6 & Thin thick weft & 18 & 6.14 & 64.85 & Bad selvedge & 16 & 7.92 & 62.38 \\
\hline 7 & Slub & 17 & 5.8 & 70.65 & $\begin{array}{l}\text { Half-width broken } \\
\text { weft }\end{array}$ & 12 & 5.94 & 68.32 \\
\hline 8 & Bad selvedge & 17 & 5.8 & 76.45 & $\begin{array}{l}\text { Soiled-greased } \\
\text { warp }\end{array}$ & 11 & 5.45 & 73.76 \\
\hline 9 & Fiber in color & 12 & 4.1 & 80.55 & Knot & 10 & 4.95 & 78.71 \\
\hline 10 & $\begin{array}{l}\text { Soiled greased } \\
\text { warp }\end{array}$ & 11 & 3.75 & 84.3 & Thin thick weft & 9 & 4.46 & 83.17 \\
\hline 11 & $\begin{array}{l}\begin{array}{l}\text { Soiled greased } \\
\text { weft }\end{array} \\
\end{array}$ & 10 & 3.41 & 87.71 & Soil grease stain & 9 & 4.46 & 87.62 \\
\hline 12 & Knot & 10 & 3.41 & 91.13 & $\begin{array}{l}\text { Soiled greased } \\
\text { weft }\end{array}$ & 6 & 2.97 & 90.59 \\
\hline 13 & Soil grease stain & 8 & 2.73 & 93.86 & $\begin{array}{l}\text { Excessive warp } \\
\text { density }\end{array}$ & 5 & 2.48 & 93.07 \\
\hline 14 & \begin{tabular}{|l}
$\begin{array}{l}\text { Excessive warp } \\
\text { density }\end{array}$ \\
\end{tabular} & 4 & 1.37 & 95.22 & $\begin{array}{l}\text { Full-width broken } \\
\text { weft }\end{array}$ & 2 & 0.99 & 94.06 \\
\hline 15 & $\begin{array}{l}\text { Excessive weft } \\
\text { density }\end{array}$ & 2 & 0.68 & 95.9 & Loose-tight warp & 2 & 0.99 & 95.05 \\
\hline 16 & Thin thick warp & 2 & 0.68 & 96.59 & Drawing-in defect & 2 & 0.99 & 96.04 \\
\hline 17 & Drawing-in defect & 2 & 0.68 & 97.27 & $\begin{array}{l}\text { Excessive weft } \\
\text { density }\end{array}$ & 1 & 0.50 & 96.53 \\
\hline 18 & Lattice & 1 & 0.34 & 97.61 & Lattice & 1 & 0.50 & 97.03 \\
\hline 19 & Warp fiber in color & 1 & 0.34 & 97.95 & Warp fiber in color & 1 & 0.50 & 97.52 \\
\hline 20 & Thin thick warp & 1 & 0.34 & 98.29 & Thin thick warp & 1 & 0.50 & 98.02 \\
\hline 21 & Double warps & 1 & 0.34 & 98.63 & Double warps & 1 & 0.50 & 98.51 \\
\hline 22 & Missing warp & 1 & 0.34 & 98.98 & Missing warp & 1 & 0.50 & 99.01 \\
\hline 23 & Temple mark & 1 & 0.34 & 99.32 & Temple mark & 1 & 0.50 & 99.50 \\
\hline 24 & Hole-tear-burst & 1 & 0.34 & 99.66 & Hole-tear-burst & 1 & 0.50 & 100.00 \\
\hline 25 & $\begin{array}{l}\text { Full-width broken } \\
\text { weft }\end{array}$ & 1 & 0.34 & 100 & Fiber in color & 0 & 0.00 & 100.00 \\
\hline
\end{tabular}

increases. Cotton fibers are shorter than polyester fibers. Moreover, in a group of cotton fibers, fibers of different lengths and thicknesses are present. When this situation is taken into consideration, the unevenness of a thread increases with increment in its cotton content [26]. Thus, specifical defects present on recycled fabrics are half-width broken weft, thin thick weft and fiber in color defects.

Whereas half-width broken defect and thin thick weft defects are caused by yarn unevenness, another special defect found in recycled fabrics is fiber in color. In the first production step of recycled yarn manufacturing which is waste sorting, separation of colored fabric pieces and mixing of colored fibers during sorting are considered to be the reason for this defect.

The stop mark $(11.95 \%)$, broken warp $(11.26 \%)$, fullwidth double wefts $(8.42 \%)$, slub $(5.80 \%)$, bad selvedge $(5.80 \%)$ defects found on $35 \%$ PES-65\% r-Cotton fabrics are considered as mechanical and labor defects [25]. Consequently, these are defects not related to the production and quality of the recycled yarns but are defects that occur during weaving. The defects, which have been commonly encountered within the scope of this study, are given in figure 3. 


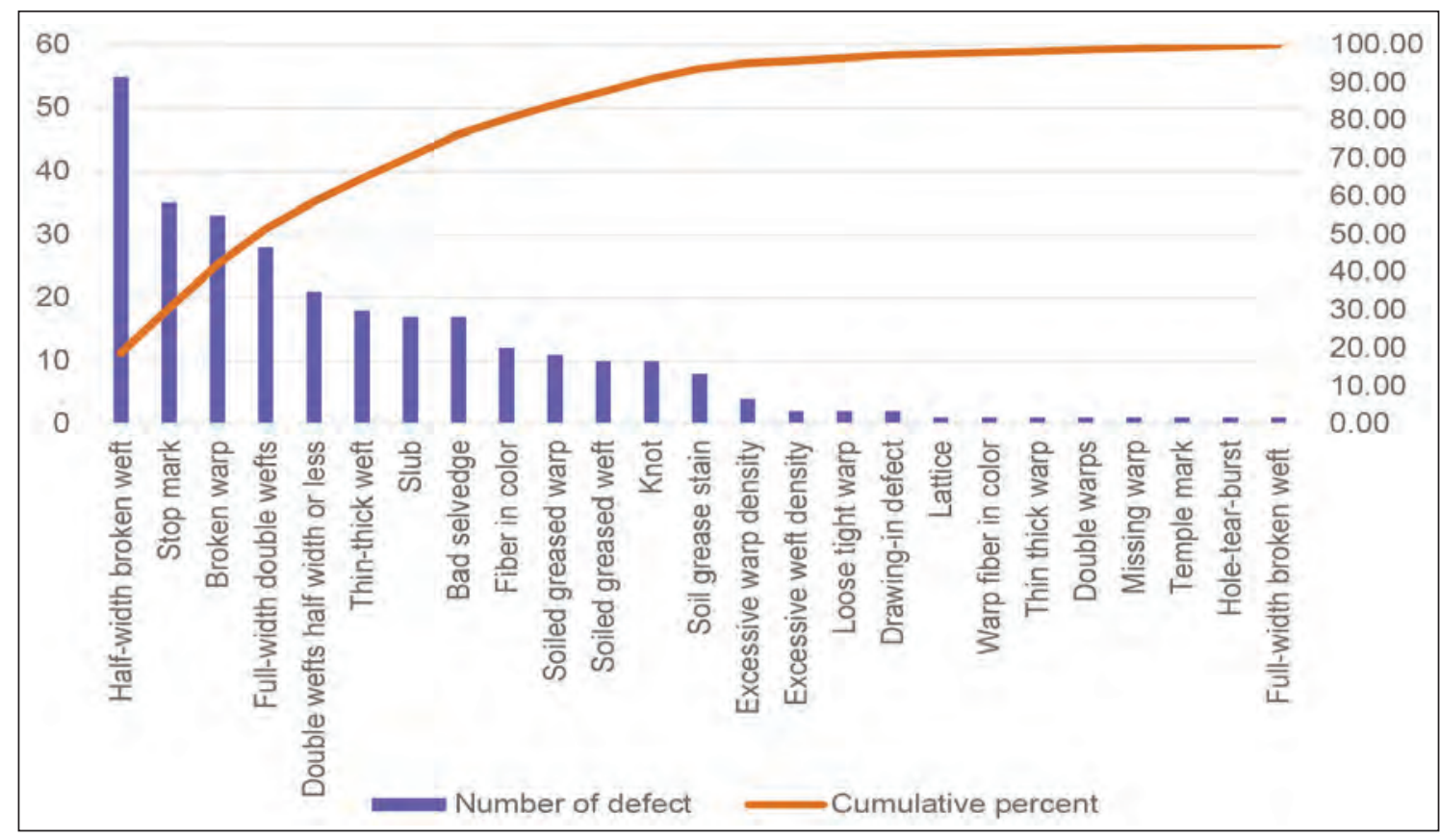

Fig. 1. Pareto diagram showing defect amounts found on 35\% PES-65\% r-Cotton fabrics

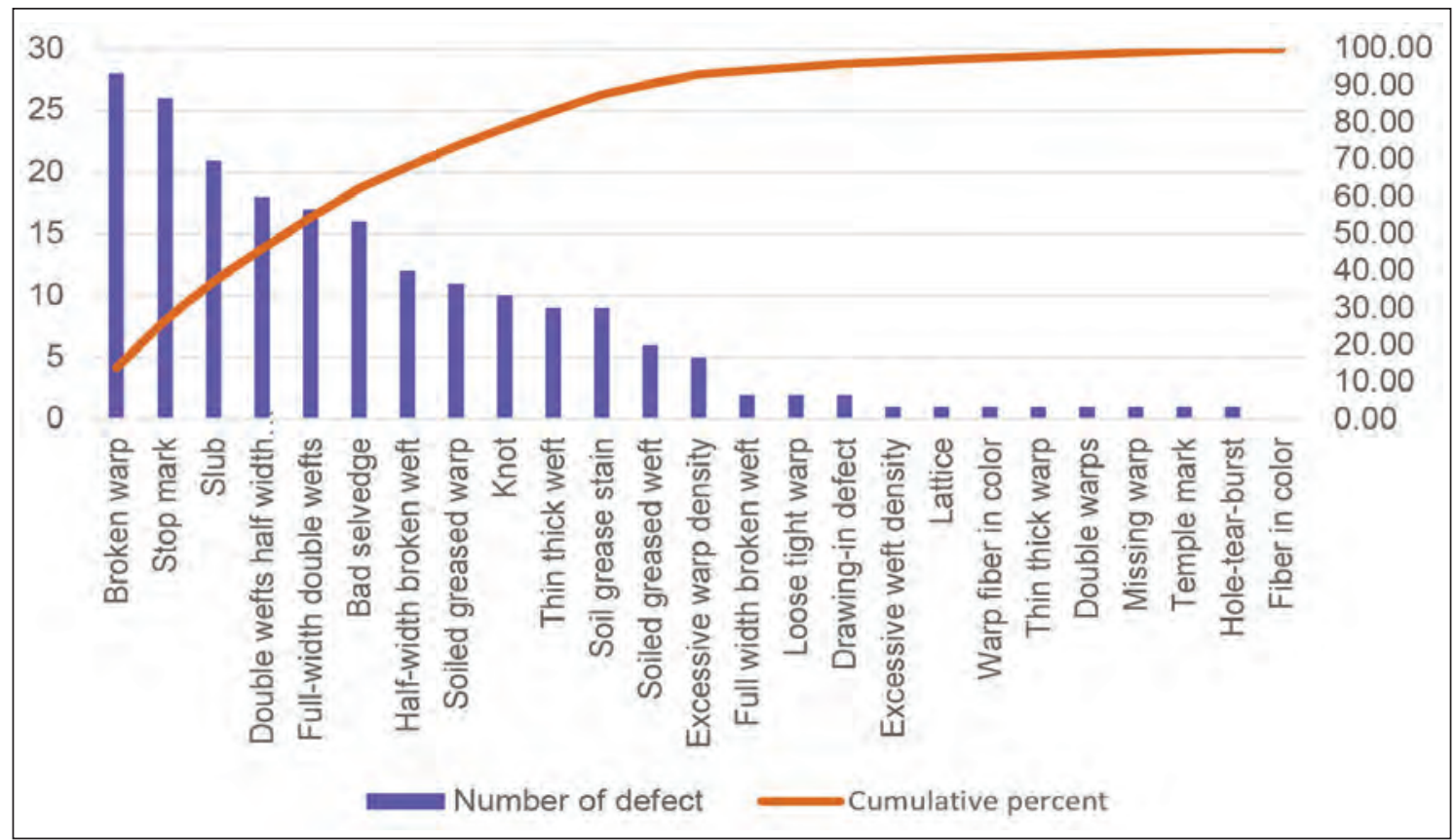

Fig. 2. Pareto diagram showing defect amounts found on $35 \%$ PES- $65 \%$ Cotton fabrics

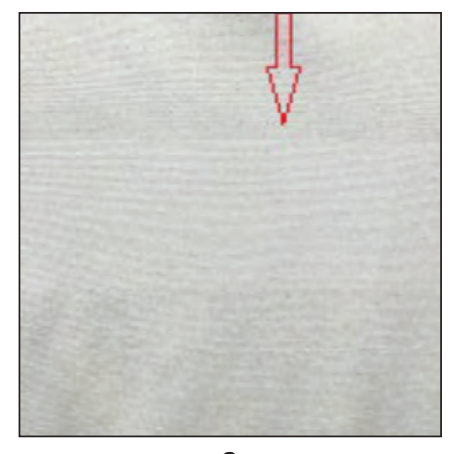

a

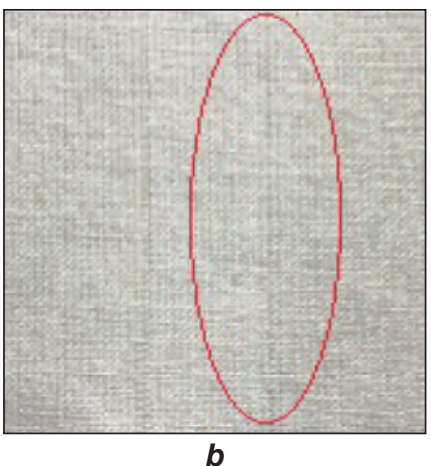

b

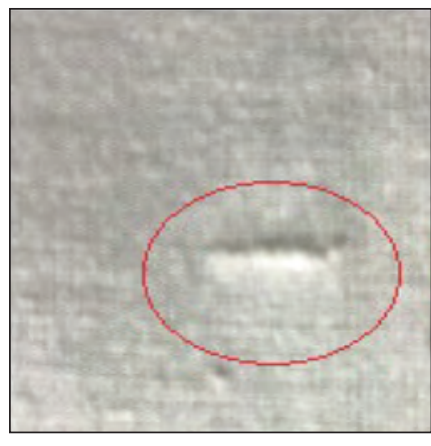

c

Fig. 3. Fabric defects commonly encountered within the scope of this study: a - stop mark; $b$ - broken warp; $c$ - slub 
Apparel manufacturing processes and percentage of second quality products

In total, 17 fabric rolls were sent to the cutting department were spread and cut. The marker efficiency values are given in table 6 . The marker includes each one from four different sizes $(36,38,40,42)$. Each spread included 100 plies. 5 spreads were laid for $53 \%$ PES-65\% r-Cotton and 5 for 35\% PES-65\% Cotton fabrics. Thus, total 10 spreads were laid. When the fabric roll ends, or when a fabric defect has to be cut out, splicing should be carried out to
$4.9 \%$ and $2.75 \%$, respectively. The difference between them is $2.15 \%$.

After the production, the distributions of defects for the second quality products with irreparable defects are shown in table 8 . These defects include cutting -measurement defects, dyeing-printing defects, sewing defects, thread-weaving defects and other defects. According to Table 8, the rates of weaving/ surface defective product in all defects are $78.57 \%$ and $69.09 \%$ for the $35 \%$ PES - 65\% r-Cotton and $35 \%$ PES - 65\% Cotton fabrics, respectively.

CUTTING AND SPREADING INFORMATION OF THE ORDER

\begin{tabular}{|c|c|c|c|c|c|c|c|c|c|c|c|}
\hline Fabric type & $\begin{array}{c}\text { Total } \\
\text { fabric } \\
\text { (m) }\end{array}$ & $\begin{array}{c}\text { Planned } \\
\text { amount } \\
\text { to be cut }\end{array}$ & $\begin{array}{c}\text { Number } \\
\text { of rolls }\end{array}$ & $\begin{array}{c}\text { Number } \\
\text { of } \\
\text { spreads }\end{array}$ & $\begin{array}{c}\text { Assort- } \\
\text { ment }\end{array}$ & \multicolumn{4}{|c|}{ CAD Efficiency } \\
(\%)
\end{tabular}

\begin{tabular}{|c|c|c|c|c|c|c|}
\hline \multicolumn{1}{|c|}{ REALIZED ORDER INFORMATION } \\
\hline Fabric type & $\begin{array}{c}\text { Total fabric } \\
\text { length } \\
\text { ( } \mathbf{m})\end{array}$ & $\begin{array}{c}\text { Planned } \\
\text { amount } \\
\text { to be cut }\end{array}$ & $\begin{array}{c}\text { Splicing } \\
\text { number }\end{array}$ & $\begin{array}{c}\text { First quality } \\
\text { (number) }\end{array}$ & $\begin{array}{c}\text { Second } \\
\text { quality } \\
\text { (number) }\end{array}$ & $\begin{array}{c}\text { Second quality } \\
\text { percentage in the } \\
\text { order (\%) }\end{array}$ \\
\hline $35 \%$ PES-65\% r-Cotton fabric & 2372 & 2000 & 43 & 1902 & 98 & 4.9 \\
\hline $35 \%$ PES-65\% Cotton fabric & 2360 & 2000 & 29 & 1945 & 55 & 2.75 \\
\hline
\end{tabular}

\begin{tabular}{|c|c|c|c|c|c|c|c|}
\hline \multicolumn{7}{|c|}{ THE DEFECTIVE PRODUCT DISTRIBUTION IN THE ORDER } \\
\hline Fabric type & $\begin{array}{c}\text { Cutting/ } \\
\text { measurement } \\
\text { defects } \\
\text { (number) }\end{array}$ & $\begin{array}{c}\text { Dyeing/ } \\
\text { printing } \\
\text { defect } \\
\text { (number) }\end{array}$ & $\begin{array}{c}\text { Sewing } \\
\text { defect } \\
\text { (number) }\end{array}$ & $\begin{array}{c}\text { Weaving/ } \\
\text { surface } \\
\text { defect } \\
\text { (number) }\end{array}$ & Others & $\begin{array}{c}\text { Second } \\
\text { quality } \\
\text { (number) }\end{array}$ & $\begin{array}{c}\text { Second quality } \\
\text { rate based on } \\
\text { weaving (\%) }\end{array}$ \\
\hline $\begin{array}{c}35 \% \text { PES-65\% } \\
\text { r-Cotton fabric }\end{array}$ & 13 & 4 & 1 & 77 & 3 & 98 & 78.57 \\
\hline $\begin{array}{c}35 \% \text { PES-65\% } \\
\text { Cotton fabric }\end{array}$ & 11 & 3 & 2 & 38 & 1 & 55 & 69.09 \\
\hline
\end{tabular}

avoid incomplete fabric pieces. For 35\% PES-65\% r-Cotton and 35\% PES, 65\% Cotton fabrics 43 and 29 splicing actions were carried out respectively. For each splicing, the overlapping fabric length was between 20 and $60 \mathrm{~cm}$. Once spreading and cutting oprations have been completed, the enumerated product pieces were bundled, labeled and dispatched to the sewing room. After the sewing processes, $100 \%$ product quality inspection was carried out and the first and second quality items were separated.

In table 7, the first and second quality ratios obtained at the end of production are given. According to this, the second quality product ratio for 35\% PES-65\% r-Cotton and 35\% PES-65\% r-Cotton fabrics are

\section{CONCLUSIONS}

This study has been conducted in order to define and determine defects encountered in weaving and apparel production processes of fabrics manufactured from recycled yarns and equivalent original yarns.

After weaving, 293 defects have been reported in 2372 meters of fabric produced by using 35\% PES $65 \%$ r-cotton yarn in weft and 202 defects have been reported in 2360 meters of fabric produced by using $35 \%$ PES - $65 \%$ cotton yarn in weft. After the production, it was seen that the ranking of defect types shows difference between 35\% PES - 65\% r-Cotton and $65 \%$ Cotton fabrics. By use of Pareto analysis 
technique, a number of defect types have been arranged in terms of their prominence. By this means, the most important fabric defects in recycled fabrics have been determined. The specific defect types confronted in recycled fabrics have been observed as half-width broken weft defect, thin-thick weft defect and fiber in color defect. It is not possible to avoid all fabric defects found during woven fabric quality inspection. However, it is necessary to carefully plan arrangements and developments related to recycled yarn manufacturing which is the first step of production in order to take the process under control and to attain required product quality. It is impossible to avoid all undesired fabric defects in the final product before their occurrence. However, via reduction of defective production, the require product quality can be achieved and operating costs can be substantially decreased.

At the end of apparel production, the fabric/surface defective product rates in all defects for 35\% PES $65 \%$ r-Cotton and 35\% PES - 65\% Cotton fabrics were $78.57 \%$ and $69.09 \%$, respectively. The fabric/ surface defective product increase in shirts produced from $35 \%$ PES - 65\% r-Cotton fabrics was $9.48 \%$. At the end of the production, percentage of the second quality products for $35 \%$ PES - 65\% r-Cotton and $35 \%$ PES - $65 \%$ Cotton fabrics were $4.9 \%$ and
$2.75 \%$, respectively. When the two fabrics produced at the same construction, under the same conditions and in the same factory, are compared, it can be said that the difference stems from recycled threads. However, when the positive environmental contributions and economical advantages of recycled yarns are taken into consideration, this difference should be ignored.

Based on its positive effect on the price and environment, the importance of yarn and fabric production from recycled raw material is growing day by day. Nevertheless, standardization of quality is needed for recycled yarns. More research study is necessary related to production of higher quality recycled yarns and fabrics more efficiently.

It is suggested that determination of various mechanical and physical properties of fabrics produced from recycled yarns of different fiber blends and blend ratios and improvement of these properties can be the subject of future research.

\section{ACKNOWLEDGEMENT}

The author acknowledges employees and directors of CNF Tekstil and Osman Canlı Tekstil who contributed to the experimental work.

\section{REFERENCES}

[1] Eser, B., Çelik, P., Çay, A., Akgümüş, D., Sustainability and Recycling Opportunities in the Textile and Apparel Sector, In: Journals of Textiles and Engineer, 2016, 23, 101, 43-60

[2] Altun, Ş., Recycling of Textile Pre-consumer and Post-Consumer Wastes and Its Environmental and Economical Effects, Uşak Ticaret ve Sanayi Odası Raporu, 2016

[3] Güngör, A., Palamutçu, S., İkiz, Y., Cotton Textiles and the Environment: Life Cycle Assessment of a Bathrobe, In: Textile and Apparel, 2009, 19, 3, 197-205

[4] Merati, A.A., Okamura, M., Producing Medium Count Yarns from Recycled Fibers with Friction Spinning, In: Text. Res. J., 2004, 74, 7, 640-645

[5] Altun, Ş., Revealing the General Profile of the Textile and Garment Waste and Recycling Facility in Turkey, Project no. 109 Y008, 2010

[6] Wulfhorst, B., Textile Technology, Translation Demir, A, Torun, A.R., İstanbul, 2003, 295-300

[7] Umar, M., Shaker, K., Ahmad, S., Nawab, Y., Umair, M., Maqsood, M., Investigating the Mechanical Behavior of Composites Made from Textile Industry Waste, In: The Journal of The Textile Institute, 2017, 108, 5, 835-839

[8] Bjo, S., Aronsson, J., Henriksson, G., Persson, A., Textile Qualities of Regenerated Cellulose Fibers from Cotton Waste Pulp, In: Textile Research Journal, 2018, 88, 21, 2485-2492

[9] Silva, R., Byrne, N., Utilization of Cotton Waste for Regenerated Cellulose fibres: Influence of Degree of Polymerization on Mechanical Properties, In: Carbohydrate Polymers, 2017, 174, 89-94

[10] Inoue, M., Yamamoto, S., Performance and Durability of Woven Fabrics Including Recycled Polyester Fibers, In: Journal of Textile Engineering, 2004, 50, 2, 25-30

[11] Larney, M., Van Aardt, A.M, Case study: Apparel Industry Waste Management: A Focus on Recycling In South Africa, In: Waste Management \& Research, 2010, 28, 36-43

[12] Zoua, Y., Reddya, N., Yang, Y., Reusing Polyester/Cotton Blend Fabrics for Composites, In: Composites Part B: Engineering, 2011, 42, 4, 4, 763-770

[13] Duru, P.N., Babaarslan, O., Determining an Optimum Opening Roller Speed for Spinning Polyester/Waste Blend Rotor Yarns, In: Textile Research Journal, 2003, 73, 10, 907-911

[14] El-Nouby, G.M., Hairiness of Yarns Made of Recycled Waste Fabric, In: J. Appl. Sci. Res., 2007, 3, 10, 972-976

[15] Halimi, T.M., Ben Hassen, M., Azzouz, B., Sakli, F., Effect of Cotton Waste and Spinning Parameters on Rotor Yarn Quality, In: Journal of The Textile Institute, 2007, 98, 437-442

[16] Kaplan, S., Göktepe, Ö., Investigation into Navel Selection for Rotor Spinning Machine Using Cotton Waste, In: Fibres \& Textiles in Eastern Europe, 2006, 14, 3, 58-62 
[17] Wanassi, B., Azzouz, B., Hassen, M.B., Recycling of Post-industrial Cotton Wastes: Quality and Rotor Spinning of Reclaimed Fibers, In: International Journal of Advanced Research, 2015, 3, 6, 94-103

[18] El-Nouby, G.M., Recycled Yarn from Textile Waste - Part I: Recycled Yarn Hairiness, In: Egy. J. Text. \& Polym. Sci. \& Tech., 2006, 11

[19] Ala, D.M., İkiz, Y., Defect Detection of Velvet Bathrobe Fabrics and Grading with Demerit Point Systems, In: Pamukkale University Journal of Engineering Sciences, 2015, 21, 7, 288-295

[20] Ala, D.M., İkiz, Y., A Statistical Investigation for Determining Fabric Defects That Occur During Weaving Production, In: Pamukkale University Journal of Engineering Sciences, 2015, 21, 7, 282-287

[21] Kısaoğlu, Ö., Fabric Quality Control Systems, In: Pamukkale University Journal of Engineering Sciences, 2006, 12, 2, 233-241

[22] Patır, S., İstatistiksel Proses Kontrol Teknikleri ve Kontrol Grafiklerinin Malatya'daki Bir Tekstil (İplik Dokuma) Işletmesinde Bobin Sarım Kontrolüne Uygulanması, In: The Journal of Social Economic Research., 2009, 9, 18, 231-249

[23] Dülgeroğlu, K.Ö., A Statistical Quality Control System in a Medium-Scale Weaving Mill: II. Control of Loom Stoppages, In: Pamukkale University Journal of Engineering Sciences, 2010, 16, 3, 303-313

[24] Dülgeroğlu, K.Ö., A Statistical Quality Control System in a Medium-Scale Weaving Mill: I. Control of Fabric Defects, In: Pamukkale University Journal of Engineering Sciences, 2010, 16, 3, 291-301

[25] Turkish Standards Institute, Definition and Terminology Relating to Woven Fabric Defects, Ankara, Türkiye, TS 471 ISO 8498, 2005

[26] Ersoy, Y., Şenol, M.F., Type of Raw Material and Production Parameters Effect on Yarn Quality: An Application on Open-End Spinning, In: The Journal of Graduate School of Natural and Applied Sciences of Mehmet Akif Ersoy University, 2017, 8, 1, 96-107

Author:

KALKANCI MIHRIBAN

Pamukkale University, Denizli Vocational School of Technical Sciences,

Camlaraltı Mah. Fakülte Cad. no. 30, 20160, Kınıkı/Denizli, Turkey

Corresponding author:

KALKANCI MIHRIBAN

e-mail: mkalkanci@pau.edu.tr 


\section{Reduction of material consumption for garments from checked fabrics}

DOI: $10.35530 / 1 T .071 .03 .1667$

\section{ABSTRACT - REZUMAT}

\section{Reduction of material consumption for garments from checked fabrics}

The use of CAD/CAM systems have greatly optimized material utilization of garment styles from plain fabrics. Processing of intricate pattern materials is still work and material consuming. Increased material consumption is obtained because of two reasons: necessity to match pattern on ready garments and unfixed textile material structure. The fabric loss related to the pattern matching necessity is the most difficult to reduce. A style of classical women jacket was tested to compare efficiency of plain and checked fabric markers for sizes 36-54. It was determined that marker length is dependent on the conformity of the size of the checked fabric repeat and the length of the longest components placed in a sectioned marker. Reducing the length of the style slightly it was possible to reduce marker length considerably for certain size markers. Marker length, fabric consumption and, with it, product costs can be reduced conforming the length of the style to the size of the checked fabric repeat. Length tolerance - acceptable slight variations of the length of the style which does not change design and visual perception of the style should be determined by designers. Specialized software could be developed to vary the length of the style in the interval of length tolerance to reduce fabric consumption and with it product costs of certain production orders. Improving manufacturing efficiency and reducing fabric use, the styles from checked materials could be included in garment collections more often.

Keywords: checked fabrics, pattern matching, marker length, cutting room management systems, automated cutting

\section{Reducerea consumului de material pentru îmbrăcămintea realizată din țesături în carouri}

Sistemele CAD/CAM au optimizat foarte mult utilizarea materialelor pentru producția de îmbrăcăminte. Totuși, utilizarea țesăturilor cu modele complexe conduce la consum mare de material. Consumul crescut de materiale este obținut din două motive: necesitatea de a potrivi modelul țesăturii și structura flexibilă a materialului textil. Pierderea de material cauzată de necesitatea de potrivire a modelului țesăturii este cel mai dificil de redus. S-a selectat un sacou clasic pentru femei, pentru a compara eficiența încadrărilor țesăturilor simple și a celor în carouri pentru mărimile 36-54. S-a observant că lungimea încadrării depinde de dimenisunea constantă a carourilor și de lungimea reperelor dintr-o încadrare secționată. Reducând lungimea produsului a fost posibilă reducerea considerabilă a lungimii încadrării pentru anumite mărimi. Lungimea încadrării, consumul de material și, odată cu aceasta, costurile produselor pot fi reduse în funcție de lungimea produsului și dimensiunea carourilor. Toleranța la lungime - variații acceptabile ale lungimii produsului care nu schimbă designul și percepția vizuală ar trebui să fie indicate de designeri. Un software specializat ar putea fi dezvoltat pentru a varia lungimea produsului în intervalul de toleranță, pentru a reduce consumul de material și, odată cu acesta, costurile produsului pentru anumite comenzi de producție. Îmbunătățind eficiența producției și reducând utilizarea materialelor, țesăturile în carouri ar putea fi incluse mai des în colecțiile de îmbrăcăminte.

Cuvinte-cheie: țesături în carouri, potrivirea modelului, lungimea încadrării, sisteme de management a secției de croire, croire automată

\section{INTRODUCTION}

Fast fashion is changing traditional rules of fashion market and customers are demanding quick changes of wide diversity of styles produced in smaller quantities [1]. The use of different patterning of the material is one option to follow customers' demands. The same jacket can look visually very different produced from plain material, striped or checked material [2]. Garment industry should use more materials with intricate patterns to increase diversity of garment collections. To ensure it, material utilization of styles from intricate pattern fabrics should be improved with it reducing fabric and final product costs.

In garment manufacturing it is well known fact that design of garment styles are always more or less dependent on several factors which influence product costs: efficiency of production process and material costs - fabric consumption and its price. As fabric costs in garment manufacturing account more than half $(50-70 \%)$ of the total product costs, designers have to create styles which are efficient in materials use. Because of this reason not often in garment collections are included styles with increase material consumption, such as, wide and long skirts (sun cut skirts), obliquely cut skirts/dresses (figure 1) also different styles from striped or checked materials.

The use of CAD/CAM systems in garment industry has greatly optimized material utilization of plain fabrics. The industry is using different management software which organize and plan all work processes starting from style designing till sell of ready goods. During the last two decades it is supplemented with new parts [1]. Specialized software which can screen 


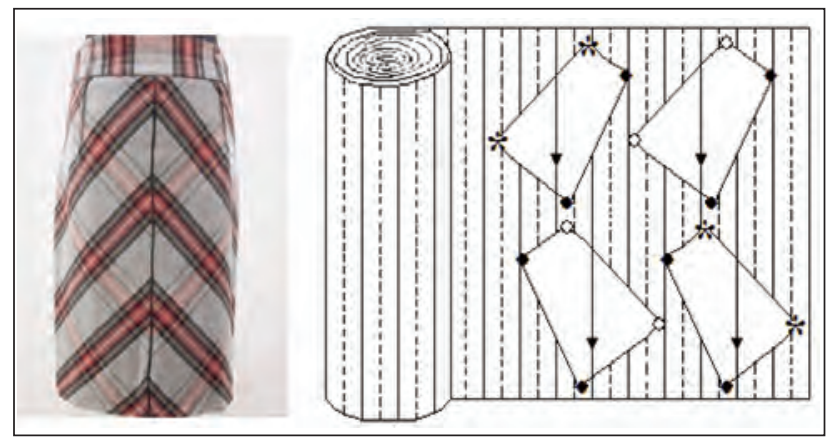

Fig. 1. Skirt with increased fabric consumption because of necessity to match fabric pattern

different nesting variants for the same order in a minute and choose the one with the highest fabric utilization level are used to reduce total fabric consumption of the order and with it also product costs [3-4]. Cut planning and scheduling improvements [5-9], as well as, possibilities to reduce fabric loss [10-11] are described in several latest papers. However, the innovations mostly improve plain fabric processing. Nesting and cutting problems of styles from intricate pattern materials are rarely researched and discussed in published sources. 1st and 2nd edition of "Industrial cutting of textile materials" [12-13] are the only books describing manual, semi and fully automated cutting methods for intricate pattern fabrics.

\section{THE REASONS OF INCREASED FABRIC CONSUMPTION}

Processing garment styles from checked fabrics, increased material consumption comparing with plain materials is obtained because of two reasons: necessity to match pattern in all produced garments and unfixed textile material structure. Problems arising from movable fabric structure can be solved in more or less effective way depending on cutting method used: manual, semi or fully automated [14-15]. The most advanced technologies offer continues singleply automated cutting when shapes of the pattern pieces in the markers are changed in accordance with imperfect fabric structure (and with it imperfect pattern) advanced on the cutting surface (Mosaic by Lectra, AutoMatch by Gerber, Multi-array scanner (MAS) system by Bullmer, VisionCut by Gemini and Match++ by Optitex, VisionPRO by Eastman) [15]. Using the fully automated single-ply processing method, material cutting process becomes fully independent on distortions of the fabric structure/pattern during cutting process.

The fabric loss related to the pattern matching necessity is the most problematical and the most difficult to reduce. In creating markers for styles from checked fabrics, pattern pieces are placed directly on the fabric (using manual cutting) or on the image of the fabric pattern. Matched fabric pattern in the ready garment has to be obtained in both directions (vertical and horizontal) and fabric pattern has to be symmetrical in all symmetrical components. To fulfill these conditions some areas of the fabric often are left unused. Besides, to ensure the same coordinated pattern in all garments produced, the start of the marker always must be at the same position of the repeat of the fabric pattern. Very often because of this last demand the certain part of the material in all its widths has to be cut off and wasted (figure 2). In critical situation this amount of fabric can be very close to full size of one pattern repeat (figure 3 ). The larger is the repeat, the larger can be fabric loss [16-17].

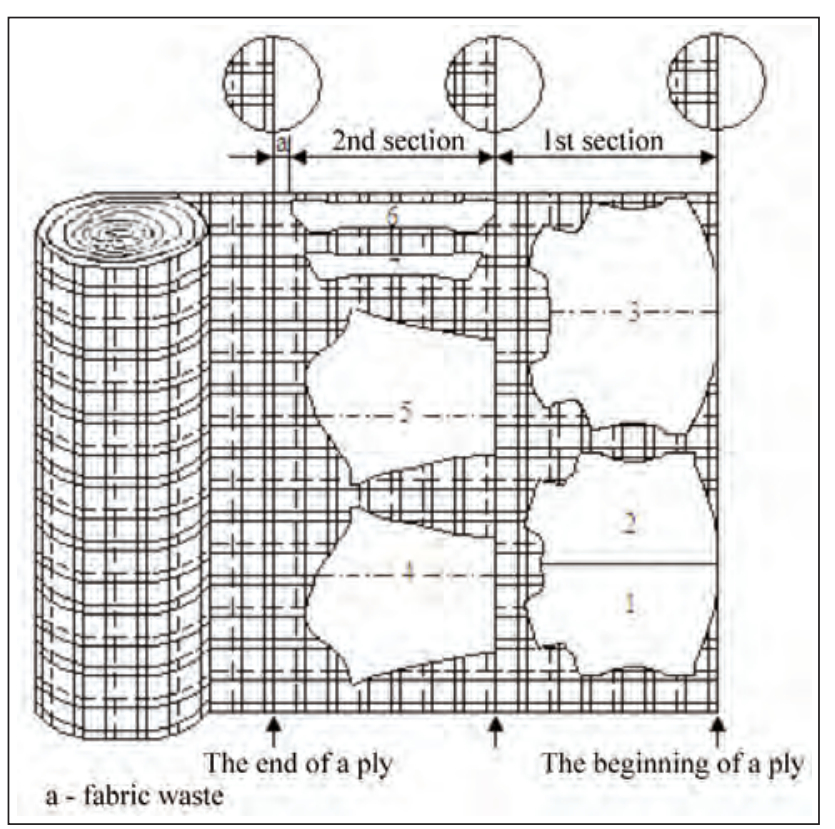

Fig. 2. Extension of marker length to match the pattern in between all garments produced

\section{FIRST EXPERIMENT}

The experiment was performed to estimate the factors that affect fabric utilization matching fabric pattern of styles from checked fabrics. 5 styles of classical women jacket were chosen. Although the styles had similar design, they differed in: length, a body part division principles (configuration and size of a front and a back side parts), a collar, pockets. Markers were created by software Mosaic (Lectra) for 10 their sizes: $36-54$ on both - plain and checked material. Total amount of tested markers - 100 (50 for plain fabric and 50 for checked fabric).

\section{Fabrics used in the experiment}

The plain and checked fabric with the same width $152 \mathrm{~cm}$ was chosen (a marker width $148 \mathrm{~cm}$ ). The checked fabric had symmetrical checks with a repeat $5.5 \times 5.5 \mathrm{~cm}^{2}$ (figure $3, b$ ).

\section{Marker making}

In making markers manually or in semi-automated way from both plain and checked fabrics, the pattern pieces of a jacket are traditionally grouped in sections to ease further cutting process (for plain and checked fabrics) and to ensure coordination of pattern on the cut components (for checked materials) [18]. Only advanced fully automated single-ply cutting 


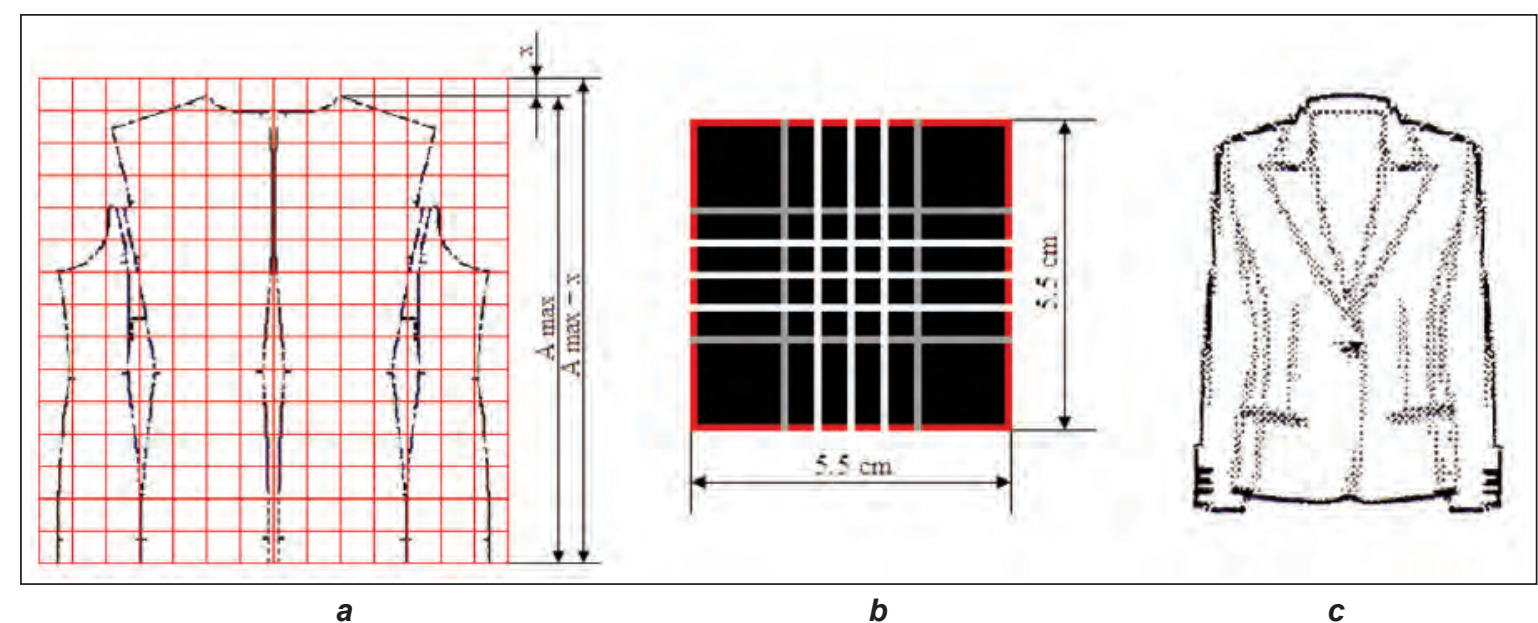

Fig. 3. The length of one section extended to the full number of fabric repeats:

$a-x$ fabric loss, $b$ - fabric repeat; $c$ - style of jacket used in the 1 st and the 2 nd experiment

method can use more efficient conventional markers where pattern pieces are not grouped in separate sections [15]. However, till now single-ply cutting [19-20] in mass production of garments is used rarely. It is fully new processing method which has to be supported with automated single-low ply cutters which are not yet typical for garment manufacturers. Because of dominate used of sectioned markers producing jackets, it was decided to use them also for experiment.

\section{Markers on plain fabric}

Pattern pieces of all sizes were laid in separate groups to create two sections:

- The first section - placed body components of the jacket: backs, back sides, front and front sides.

- The second section - placed upper sleeves, under sleeves and facings.

All other smaller size pattern pieces were placed in available free areas in the first or second section. If all body components could not be placed in the first section, one or two pattern pieces of the side components were moved to the second section (mostly for sizes up to 46, figure $4, a$ and 5,a). Analyzing obtained markers for the plain fabric, it was found that marker length was dependent on the shape and size of the components and their mutual placement in the marker. Average marker efficiency for all 10 tested sizes of 5 styles was $73.9 \%$.

Plain fabric marker length and marker efficiency for all 10 tested sizes of the style 3 (figure 3,c) are showed in the table 1. The same style will be tested also in the 2nd experiment.

\section{Markers on checked fabric}

To ensure precise pattern coordination in all cut components two different actions had to be performed by making sectioned markers on checked material:

- pattern pieces had to be placed on the fabric in certain way to coordinate horizontal and vertical lines of the fabric on the cut components and to ensure symmetry of the pattern on symmetrical components;

- certain fabric allowances had to be added around pattern pieces to support further manual or semiautomated cutting of components [14, 17-18].

\begin{tabular}{|c|c|c|c|c|c|c|c|}
\hline \multicolumn{7}{|c|}{ PLAIN FABRIC MARKER LENGTH AND MARKER EFFICIENCY } \\
\hline \multirow{2}{*}{ Size } & Marker length (cm) & \multicolumn{2}{c|}{ Marker length difference } & \multicolumn{2}{c|}{ Marker efficiency (\%) } & Marker efficiency \\
& Plain & Checked & $\mathbf{c m}$ & $\%$ & Plain & Checked & difference (\%) \\
\cline { 2 - 7 } & 152 & 165 & 13 & 7.8 & 74.3 & 69.8 & 6.0 \\
\hline 36 & 157 & 170.5 & 13.5 & 7.9 & 74.8 & 69.9 & 6.5 \\
\hline 38 & 167.2 & 181.5 & 14.3 & 7.8 & 75.3 & 69.3 & 7.9 \\
\hline 40 & 171.2 & 187 & $15, .8$ & 8.4 & 74.4 & 68.2 & 8.3 \\
\hline 42 & 182 & 198 & 16 & 8.0 & 74.6 & 66.1 & 8.5 \\
\hline 44 & 185.2 & 203.5 & 18.3 & 9.0 & 74.3 & 65.3 & 12.1 \\
\hline 46 & 195.2 & 214.4 & 19.2 & 8.9 & 74.8 & 65.6 & 12.2 \\
\hline 48 & 203.9 & 225.7 & 21.8 & 9.6 & 74.6 & 66.3 & 11.1 \\
\hline 50 & 209.4 & 232.1 & 22.7 & 9.7 & 74.1 & 66.0 & 10.9 \\
\hline 52 & \multirow{2}{*}{212.2} & 236.5 & 24.3 & 10.3 & 74.0 & 66.8 & 9.7 \\
\hline \multirow{2}{*}{54} & & & 0 & 8.7 & 74.5 & 67.3 & 9.6 \\
\hline
\end{tabular}


The largest, most important pattern pieces - both back components and both front components - were placed in the marker next to each other to ensure symmetrical placement of vertical lines in their pattern (figure $3, a, 4, b$ and $5, b$ ). All other body pattern pieces (back sides, front sides) were placed next to their main components or in some other free spaces in the markers aligning their pattern in horizontal and vertical directions. The described actions did not change the placement of the pattern pieces as similar placement of body pieces were used also in plain fabric markers.

Fabric allowances were added on side edges of symmetrical front and back components placed with their inner edges together. For other components, the fabric allowances were added on one of their sides. A fabric allowance, one repeat wide, was added also to the small components (flaps of pockets, welts, others) to coordinate their pattern later with the checks of their main components. The described actions influenced placement of the pattern pieces in width of the fabric:

- the number of pattern pieces placed in one section reduced or it was necessary to replace some pattern pieces with smaller ones in the section for the most part of tested markers (figure $5, b$ );

- comparatively large areas of the fabric appeared which had to be left unused (figure $3, b$ and $4, b$ ).

The length of minimum one section of the marker was determined by the projectional length of longest components placed in the sections - a back, a front or a facing (figure $3, a$ ). The length of the sections was also depended on a repeat of the fabric. To ensure coordinated pattern in all garments cut from more than one fabric ply, the length of the marker had to be extended to full length of " $n$ " fabric repeats (checks) (figure 2). This additional action increased the length of the markers, and with it, reduced fabric utilization.

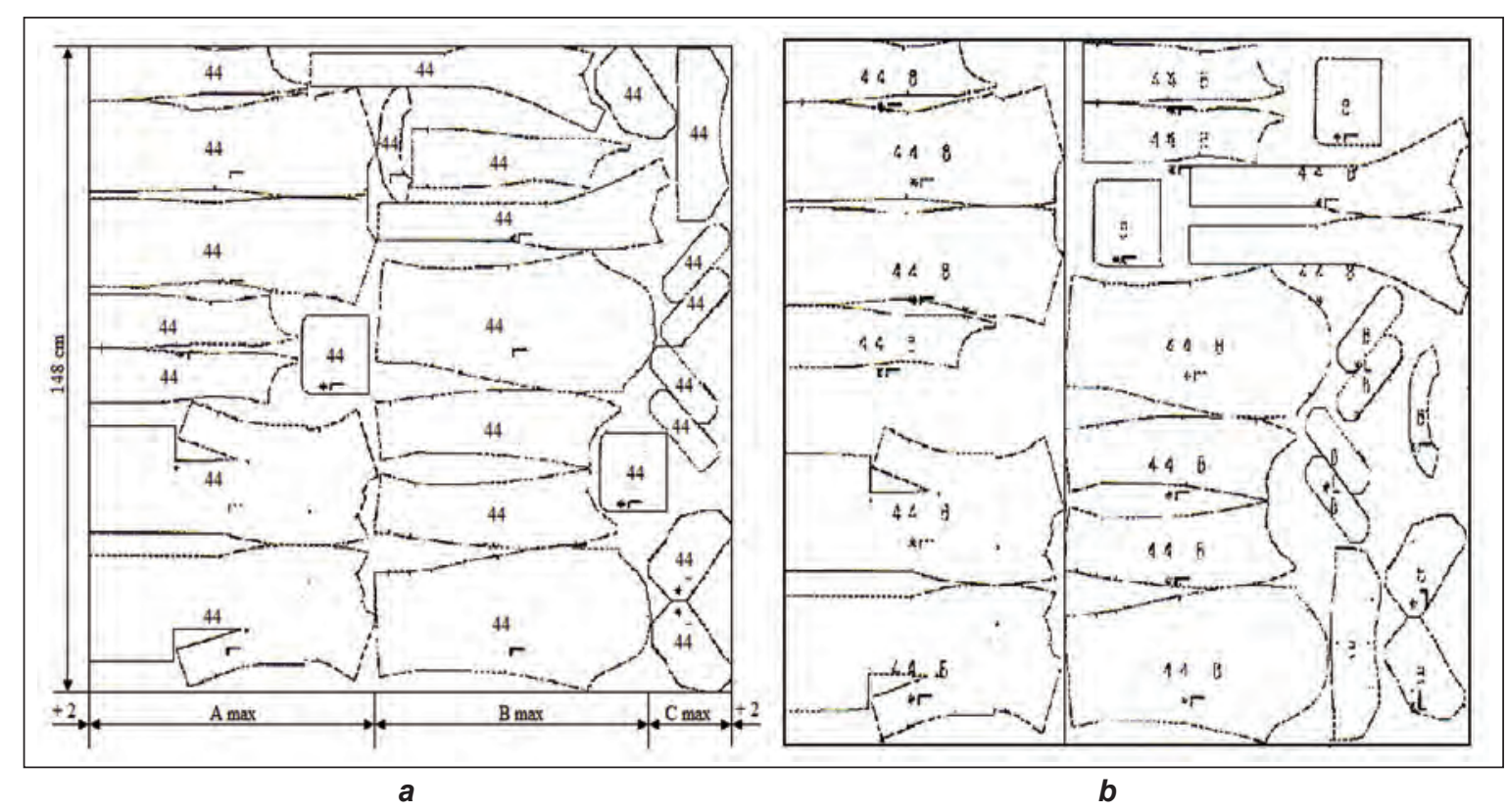

Fig. 4. Markers of the size 44 for: $a$ - plain fabric; $b$ - checked fabric

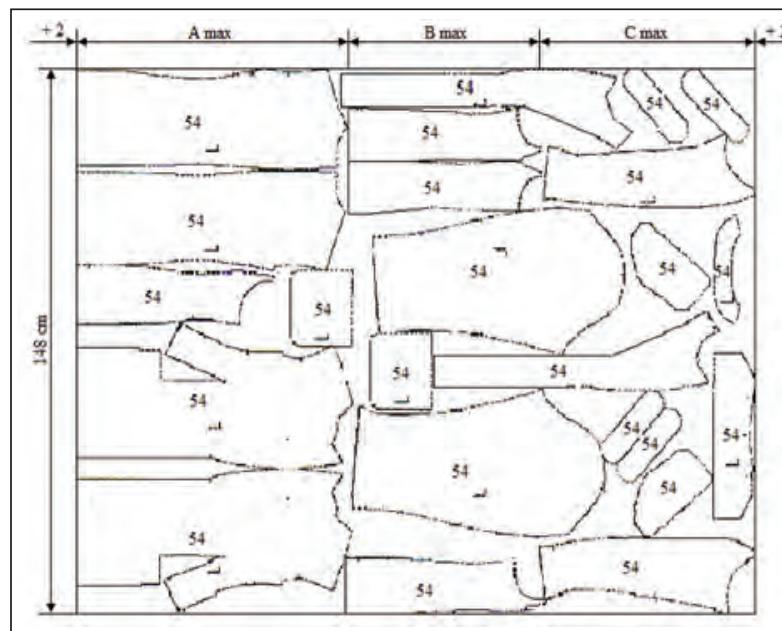

a

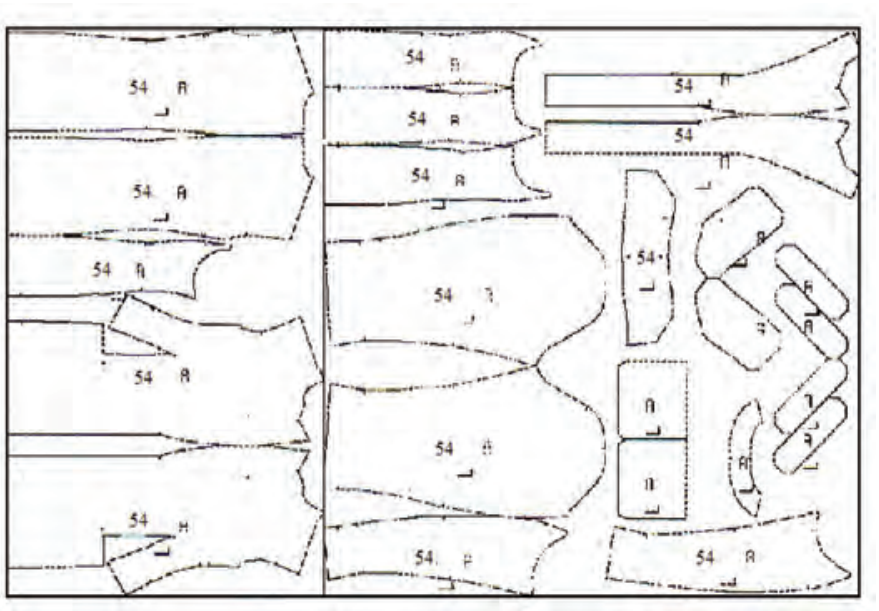

b

Fig. 5. Markers of the size 54 for: $a$ - plain fabric; $b$ - checked fabric 


\begin{tabular}{|c|c|c|c|c|c|c|c|}
\hline \multicolumn{8}{|c|}{ CHECKED FABRIC MARKER LENGTH AND MARKER EFFICIENCY } \\
\hline \multirow{3}{*}{ Size } & \multicolumn{2}{|c|}{ Original length jacket } & \multicolumn{2}{c|}{ Reduced length jacket } & Reduction of & \multicolumn{2}{|c|}{ Marker efficiency (\%) } \\
\cline { 2 - 8 } & $\begin{array}{c}\text { Marker } \\
\text { length (cm) }\end{array}$ & $\begin{array}{c}\text { Full fabric } \\
\text { repeats }\end{array}$ & $\begin{array}{c}\text { Marker } \\
\text { length (cm) }\end{array}$ & $\begin{array}{c}\text { Full fabric } \\
\text { repeats }\end{array}$ & $\begin{array}{c}\text { length } \\
\text { (cm) }\end{array}$ & $\begin{array}{c}\text { Original } \\
\text { length jacket }\end{array}$ & $\begin{array}{c}\text { Reduced } \\
\text { length jacket }\end{array}$ \\
\hline 36 & 165 & 30 & 165 & 30 & 0 & 69.8 & 68.9 \\
\hline 38 & 170.5 & 31 & 165 & 30 & -5.5 & 66.1 & 69.3 \\
\hline 40 & 181.5 & 33 & 181.5 & 33 & 0 & 68.6 & 66.8 \\
\hline 42 & 187 & 34 & 187 & 34 & 0 & 68.5 & 64.3 \\
\hline 44 & 198 & 36 & 192.5 & 35 & -5.5 & 66.1 & 68.4 \\
\hline 46 & 203.5 & 37 & 203.5 & 37 & 0 & 66.3 & 65.2 \\
\hline 48 & 214.4 & 39 & 214.4 & 39 & 0 & 65.8 & 65.3 \\
\hline
\end{tabular}

Necessity to coordinate checked pattern and the use of additional fabric allowances changed the placement of pattern pieces in the checked fabric markers and, comparing with plain fabric markers, increased their length. The marker length for checked material of all 5 tested styles increased in average for $8.2 \%$. The marker efficiency for checked material of all 5 tested styles reduced in average for $10.2 \%$.

Checked fabric marker length and marker efficiency for all 10 tested sizes of the style 3 (figure $3, c$ ), (this style will be tested also in the 2nd experiment, see below) are showed in the table 1 .

The results of the 1st experiment showed that the length of a sectioned marker (material use) is more influenced by the length of the longest pattern pieces determining the length of separate sections and the size of a fabric repeat and less influenced by mutual placement of the pattern pieces in the markers. It was also seen that there is no certain correlation between the size of the style/ pattern pieces and marker efficiency (fabric utilization). The number of other parameters and their mutual combinations (mutual placement of pattern pieces in the marker) influences marker efficiency and fabric utilization level. They are:

1. for plain fabric - the width of the fabric and the dimensions, shape, number of the pattern pieces;

2. for checked fabric - the width of the fabric, size of the repeat, kind of the repeat/ pattern (symmetrical, asymmetrical), the dimensions, shape, number of the pattern pieces and pattern matching requests.

\section{SECOND EXPERIMENT}

Performing the 1st experiment it was noticed that in few markers created for checked fabric (12 markers from 50 ) the length of a section (with it also the length the marker) had to be extended almost for whole size of the checked fabric repeat as the longest component exceeded previous repeat of the fabric for very small value - only $1-2 \mathrm{~cm}$. For example, for the size 44 of the styles 3 (figure $3, c$ ): the length of first section (determined by the length of the front/back) had to be extended from $78.6 \mathrm{~cm}$ to $82.5 \mathrm{~cm}$ - to get full 15 repeats of the fabric. Thus, the marker length extended for $3.9 \mathrm{~cm}$. To coordinate pattern in between fabrics plies this amount of fabric will be cut off and wasted (figure $3, a$ ). Producing this size jacket in large qualities fabric loss could be serious.

To try to avoid above described critical fabric loss it was decided to make the 2 nd experiment. It was decided to change slightly the length of the longest components and with it - the length of the style, and to improve fabric utilization. The jacket of the style 3 which had the critical fabric loss in the 1st experiment was chosen for the 2 nd experiment (figure $3, c$ ). The original length of the jacket $(2 \mathrm{~cm}$ above hip level) allowed to make needed changes not influencing visual perception and design of the style.

The length of the jacket was reduced for $1.6 \mathrm{~cm}$. The needed changes were performed for all components of all tested sizes and new sectional markers were created. It was seen that reducing the length of the jacket for $1.6 \mathrm{~cm}$ :

- for sizes 38 and 44 the marker length reduced (for 5.5.cm - one fabric repeat) and marker efficiency increased (size 38 from $66.1 \%$ to $69.3 \%$, for size 44 from $66.1 \%$ to $68.4 \%$ ).

- for all other sizes marker the length of the markers did not change, but the marker efficiency reduced (table 2).

The results of the 2nd experiment show that it is possible to reduce sectioned marker length and with it fabric use reducing slightly the length of the style. Although for the 5 markers from 7 tested the length did not change but fabric utilization reduced, final positive effect - reduction of total fabric consumption - could be obtained developing certain production orders. The orders for garment sizes from "critical loss markers" are larger, the larger fabric savings can be obtained from slight reduction of the length of the style, the lower product costs for the ready goods.

\section{DISCUSSIONS}

The experiments proved that it is possible reduce total fabric consumption of certain manufacturing orders reducing fabric loss which appears because of necessity to match fabric pattern on ready garments. Marker length, with it fabric consumption, can be reduced conforming the length of the style with the 
fabric pattern repeat. Obviously the larger is the fabric repeat the larger fabric loss can appear and, and the same time, less possibilities exist to reduce fabric consumption correcting the length of the style.

Length tolerance - acceptable slight variations of the length of the style. It could be used for styles whose design and visual perception cannot be changed reducing their length in the interval of the length tolerance. The length tolerance has to be determined by the designer for the every certain style. The length tolerance could be used for different kind of garments - skirts, dresses, jackets, coats. It can be larger for longer styles and smaller or even unacceptable for short styles where length of the style is strictly determined by its proportions or completation with other styles.

Reduction of fabric consumption and with it total product costs by help of slight variations of the length of the style can be effective using semi-automated cutting methods and marker making software for patterned fabrics, such as, Mosaic by Lectra, Visual Nest by Morgan Tecnica, Match It by Bullmer, In Vision by Gerber, supplementing them with new parts [14-15]. Specialized cut planning software which screens different nesting variants for the same order and choose the one with the highest fabric utilization level is already developed and used by industry for plain fabrics [3, 4]. Similar principle could be used developing new software to detect "critical loss markers" and their importance in certain production orders (depending on ordered quantities) for checked fabric styles. Work steps could be following:

- the user of the software inserts the length tolerance for the certain style - value (in $\mathrm{cm} / \mathrm{mm}$ ) by which the length of the style could be reduced to reduce total fabric composition of the order.

- in semi or fully automated way markers are created for all necessary sizes of the order;

- software detects critical marker/markers - markers where the longest component in the section exceeds the end of the fabric report only up to length tolerance;

- software calculates how large could be total fabric loss for whole order because of the "critical markers" taking into account number of garments ordered from the "critical markers";
- software calculates total fabric consumption and compares it with fabric loss obtained from "critical markers";

- software changes the length of the components of the style for necessary value $(\mathrm{cm} / \mathrm{mm})$ to improve efficiency of the "critical markers";

- software creates new markers for all sizes of the order;

- software calculates total fabric consumption for the order and compares it with the original variant.

Above described work principle is only general. After necessary software is developed it has to be checked with new experiments and improved in detailed way.

\section{CONCLUSIONS}

In this paper the marker making of garment styles from checked fabrics was analyzed to reduce the fabric consumption for certain production orders from checked materials. The main reasons of increased fabric losses comparing with plain fabrics were determined. It was tried to find possibilities to reduce fabric consumption conforming the length of a style to efficient fabric use in sectioned markers. As the result of two performed experiments following conclusions were made:

1. The length of the sectioned marker is dependent on the shape and dimensions of the components, size of the fabric pattern repeat and the length of the longest components - the length of the style included in the marker.

2. Marker length, fabric consumption and, with it, product costs can be reduced conforming the length of the style with the size of the checked fabric repeat.

3. Designing styles from checked fabrics should be determined length tolerance - the interval in which the length of the style can be reduced not affecting its design and visual perception.

4. Using appropriate software the length tolerance could be used to reduce fabric consumption for certain manufacturing orders in efficient way.

5. Improving manufacturing efficiency and reducing fabric use, the styles from checked materials could be included in garment collections more often. They could help to raise diversity of garment collections demanded by market in efficient way.

\section{REFERENCES}

[1] Senanayake, M., Product development, production planning and selection of materials, In: Nayak, R. Padhye, Automation in Garment Manufacturing, Woodhead Publishing, Elsevier, ISBN 9780081012116, Cambridge, 2015, 19-56

[2] Beikule, I., Vilumsone, A., Vilumsone, I., Design of clothing using visual correction, In: 4th International Textile, Clothing and Design Conference - Magic World of Textiles. Dubrovnic, Croatia, 2008, 160-173

[3] Vilumsone-Nemes, I., Automated cutting room management systems to reduce fabric consumption, In: 5th International Scientific-Professional Symposium Textile Science and Economy, Tehnički fakultet »Mihajlo Pupin«, Zrenjanin, 2014, 119- 126

[4] Vilumsone-Nemes, I., Lay planning and marker making in textile cutting operations, In: Industrial cutting of textile materials, 2nd edition, Woodhead Publishing, Elsevier, ISBN-9780857091345, Cambridge, 2018, 13-26

[5] Wong, W.K., Chan, C.K., IP, W.H., Optimization of spreading and cutting sequencing model in garment manufacturing, In: Computer Industry, 2000, 43, 1, 1-10 
[6] Wong, W.K., Chan, C.K., An Artificial Intelligence Method for Planning the Clothing Manufacturing Process, In: Journal of Textile Institute, 2001, 92, 2, 168-178

[7] Kwong, C.K, IP, W.H., Chan, C.K., Wong, W.K., Optimization of manual fabric cutting process in apparel manufacturing using genetic algorithms, In: International Journal of Advanced Manufacturing Technology, 2005, $27,1,152-158$

[8] Wong, W.K., Guo, Z.X., Leung, S.Y.S., Applications of artificial intelligence in the apparel industry: a review, In: Textile Research Journal, 2011, 81, 1871-1892

[9] Wong, W.K., Guo, Z.X., Leung, S.Y.S., Optimizing decision making in the apparel supply chain using artificial intelligence (Al): From production to retail, Woodhead Publishing, ISBN 9780857097798, Cambridge, 2013

[10] Dumishllari, E., Guxho, G., Influencce of lay plan solution in fabric efficiency and consume in cutting section, In: AUTEX Research Journal, 2016, 16, 4, 222-227

[11] Azmat, H., Naveed, T., Zhong, Y., Reducing fabric wastage through image projected virtual marker (IPVM), In: Textile Research Journal, 2017, 88, 14

[12] Vilumsone-Nemes, I., Industrial cutting of textile materials, 1st edition, Woodhead Publishing, Elsevier, Cambridge, 2012

[13] Vilumsone-Nemes, I., Industrial cutting of textile materials, 2nd edition, Woodhead Publishing, Elsevier, Cambridge, 2018

[14] Vilumsone-Nemes, I., Multiply processing of styles from intricate pattern fabrics, In: Industrial cutting of textile materials, 2nd edition, Woodhead Publishing, Elsevier, Cambridge, 2018, 241-253

[15] Vilumsone-Nemes, I., Automated single ply processing of styles from intricate pattern fabrics, In: Industrial cutting of textile materials, 2nd edition, Woodhead Publishing, Elsevier, Cambridge, 2018, 255-265

[16] Vilumsone-Nemes, I., Marker making for garment styles from intricate pattern fabrics, In: Industrial cutting of textile materials, 2nd edition, Woodhead Publishing, Elsevier, Cambridge, 2018, 255-265

[17] Vilumsone, I., Spulgite, M., Purina, B., Beikule, I., Marker making for materials with striped patterns, In: Scientific Proceedings of Riga Technical University, 9th part: Material Science Textile and Clothing Technology., Riga, Latvia, 2009, 4, 119-125

[18] Vilumsone-Nemes, I., Manual marker making, spreading and cutting materials with check patterns, In: Industrial cutting of textile materials, 1st edition, Woodhead Publishing, Elsevier, Cambridge, 2012, 171-179

[19] Nemeša, I., Automated knife cutting systems to process textiles, In: Tekstilna Industrija, 2017, 4

[20] Nemeša, I., Automatizovano jednoslojno krojenje tekstilnih materijala, In: Tekstilna Industrija, 2018, 2, 23-29

\section{Authors:}

\section{INETA VILUMSONE-NEMES ${ }^{1}$, DANA BELAKOVA ${ }^{2}$}

${ }^{1}$ University of Novi Sad, Technical faculty "Mihajlo Pupin”, Department of Textile Sciences and Clothing Design Đure Đakovića bb, 23000, Zrenjanin, Serbia

${ }^{2}$ Riga Technical University, Institute of Design Technologies of the Faculty of Materials Science and Applied Chemistry, Kīpsalas 6, Riga, Latvia

e-mail: dana.belakova@rtu.Iv

Corresponding author:

INETA VILUMSONE-NEMES

e-mail: inetavil@gmail.com 


\title{
Study on the origin and evolution of the Chinese batik
}

\author{
DOI: 10.35530/IT.071.03.1694
}

\section{ABSTRACT - REZUMAT}

\section{Study on the origin and evolution of the Chinese batik}

The origin and spread of the Chinese batik have always been a controversial issue in the field of Chinese dyeing and waving historiography. The systemic analysis was carried out by the methods of textile archaeology and literature research in this paper. Conclusions have been made as follows: there were two models in the origin of Chinese batik. One, such as the Central Plains area, was the type of external afference. Another model, such as the south-western ethnic areas, was the type of generating from the inside of the area. The transmutation of batik in Central Plain areas have passed through three stages: introduction from the Eastern Han Dynasty to the Northern and Southern Dynasties, mass acceptance during the Sui Dynasty, Tang Dynasty and Five Dynasties, obsolescence during the Two Song Dynasties. From the perspectives of the reason, the rapid disappearance of batik in the Central Plains areas were caused by the special internal and external environment and the development trend of dyeing technology of the Song Dynasty.

Keywords: batik, origin, transmission, ash resist dye, clamp resist dye

\section{Studiu privind originea și evoluția tehnicii batik în China}

Originea și răspândirea tehnicii batik au reprezentat întotdeauna o problemă controversată în domeniul istoriografiei vopsirii și țeserii din China. Analiza sistemică din această lucrare a fost realizată prin metodele de arheologie textilă și cercetare în literatura de specialitate. Concluziile au fost următoarele: la originea tehnicii batik din China au existat două modele. Unul provine din zona Câmpiei Centrale, reprezentând tipul extern. Un alt model provine din zonele etnice din sud-vest, reprezentând tipul care a fost generat din interiorul zonei. Transmutarea tehnicii batik în zonele Câmpiei Centrale a trecut prin trei etape: introducere din dinastia Han din est în dinastiile din nord și sud, acceptarea în masă în timpul dinastiei Sui, dinastiei Tang și în timpul celor cinci dinastii, ieșirea din uz în timpul celor două dinastii Song. Din perspectivele motivului dispariției acestei tehnici, aceasta a avut loc rapid în zonele Câmpiei Centrale din cauza mediului intern și extern și a tendinței de dezvoltare a tehnologiei de vopsire a dinastiei Song.

Cuvinte-cheie: batik, origine, transmitere, colorant rezistent din cenușă

\section{INTRODUCTION}

As one of the four great fabric dyeing (tie dye, clamp resist dye, wax resist dye and ash resist dye) in China, batik was a highlight in the Central Plains region during the period of the Sui and Tang dynasties. However, batik disappeared in the Central Plain areas after the Song dynasty and there are some historical relics only in south-western ethnic areas today.

Therefore, exploring the problem of the origins and spread of Chinese batik technique plays a very important role in study on essence of extinction of batik in the Central Plains region. The author states that types of origin of Chinese batik technique should be first analysed. Then the division of development stages of it should be carried out. On this basis, the cause of extinction of batik can be summed up in the end.

\section{ORIGIN OF CHINESE BATIK TECHNIQUE}

The origin of Chinese batik has no background of its origin in spinning and dyeing. The author views the origin of Chinese batik technique can be divided into two types: external afference and internal self-generating.

\section{The type of external afference}

The theory of the external afference refers to opinion that Chinese batik technique was obtained from communication with the outside world rather than originated from China. British scholar L.W.C. Miles holds that fabrics with batiks appeared in 1500 B.C. Having studied on the pattern of the Ishtar batik fabric (figure 1) unearthed in Xinjiang, Zhao Feng concluded that it has obvious characteristics of Indian culture. It can be deduced from the conclusion that Chinese batik technique originated from India [1]. Lei Guiuan and Forrest assume that it originated from Java and original timeline is now difficult to identify [2]. 


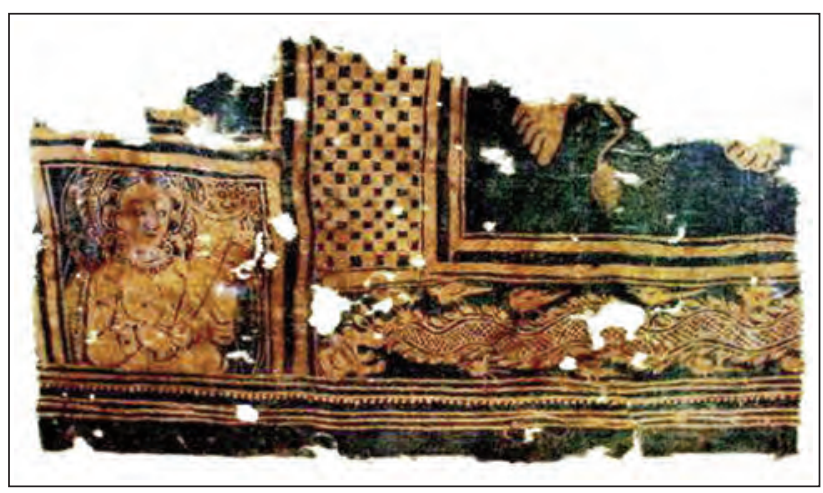

Fig. 1. Ishtar batik fabric

All versions of Song of wax printing, the ancient song of Miao ethnics, show the batik was invented and created by native girls. Second, legend of Miao nationality tells that Chi You, an ancestor of Miao, was defeated and turned into the maple when he died. Miao People apply the maple-leaf juice on their banners and clothes to memorialize Chi You. Thus the secret of resist dyeing had been discovered and has been retained in Basha Miao households in Congjiang, Guizhou province. Therefore, the batik evolved from maple liquid dyeing is Chinese Miao. The batik technique was fully utilized when Miao and Yao (Miao and Yao had genetic relationship and have been deemed as Wuyi Man in Chinese ancient books) had completed their migration to southwest china in Qin and Han Dynasties (220 B.C. - 220 A.D.), which shows that Miao and Yao have had the batik technique before Qin and Han Dynasties. In a word, the time of origin of batik technique in Miao and Yao has far to be earlier than the East Han Dynasty when the batik technique was present in western regions. So, the model of origins of Chinese batik technique is internal self-generation from the angle of minority nationalities.

\section{DEVELOPMENT AND EVOLUTION OF THE BATIK TECHNIQUE IN THE CENTRAL PLAINS OF CHINA}

It is well known that the batik technique of the Central Plain areas stemmed from India and introduced from Western Regions (afferent pathway similar to Buddhism). However, the batik is not the same as Buddhism whose development stretches without a break. It is like a shooting star quickly disappearing in the long river of history. The authors think the development and evolution of the batik in the Central Plain areas undergone three process: Introduction from the Eastern Han Dynasty to the Southern and Northern Dynasties (A.D. 25-589), wide popularity during the period of Sui-Tang and Five Dynasty (A.D. 581-960) and then decline in the Two Song Dynasties (A.D. 960-1279).

Introduction of the batik technique in the Central Plains area

The unearthed textiles, blue wax printing wool fabric and cotton fabric in the Northern Dynasties (A.D. 396-581), of Wuyulaike Site in the Yutian county of Xinjiang are proofs that the batik technique was brought to the center of China from Western Region besides the Ishtar batik fabric. Obviously, these two batik fabrics were not fabricated by artisans of Han nationality. The reasons are as followings:

- Wool fabric is main cloth material of northern minority nationality, silk, ko-hemp and flax are mainly used for the cloth material in the Central Plains Area.

- Cotton fabric introduced as "Tu-gong" from Western Regions and Southwestern ethnic areas and did not spread to Yangtse River Delta Area until the ending of Song and beginning of Yuan Dynast. sons are as follows. 
- The two batik fabrics were discovered in Western Regions, the communications centre of Silk Road. It is well known that Western Regions are the convergent center of West Asia, South Asia and Central Plains civilization. Meanwhile, the related records about the batik fabrics of West Asia and South Asia has emerged greatly early before Anno Domini. Physical batik fabrics did not appear in Central Plains until the period of the Sui and Tang Dynasties.

Therefore, the author holds that the possibility that the batik spread from Western Regions to the Central Plains is high.

Wide popularity of the batik technique in the Central Plains area

During the Sui, Tang and Five Dynasties, the batik quickly became popular in the Central Plains and was rapidly improved in technology, which can be verified with textile archaeology. The Viewpoint that the batik had been popular and developed rapidly in Central Plains was hinted by two evidences: the banners in Mogao Grottoes in Dunhuang and the batik fabrics of the Tang Dynasty had been kept in the Shosoin of Nara in Japan.

Evidence 1: A lot of unearthed batik fabrics of the Tang Dynasty in Mogao Grottoes in Dunhuang. In the 1960s, there were a lot of batik fabrics in banners discovered in Mogao Grottoes, e.g. cloud bird flowergrass patterns on lake blue background of the silk batik, the lucidum flower-bird pattern on deep red background of the silk batik, the cloud and flower-bird pattern on yellow background of the batik silk and the flower pattern on earthy yellow background of the batik silk [5]. The author considers the possibility that they all were made from the Central Plains is great. The reason is as follows: all are silk fabrics. As is known, the Central Plains, silk fabrics' hometown, can provide conditions for silk fabrics manufacturing. Secondly, as early as the Qin and Han Dynasties, the Central Plains people had a tradition of using lucidum, Ruicao and auspicious cloud as "Xiang Rui" patterns in silk fabric. In addition, there was also a kingdom of Gaochang in the Western Regions established by the Han nationality in the Sui and Tang Dynasties. According to researched historical documents, Gaochang was actually a local regime established by Han immigrants who migrated to the Western Regions during the Han-Jin period. The technique of silk weaving of Gaochang was surprisingly excellent, which was verified with the wooden figures of the Kesi belt in Zhangxiong the tomb. Showing the artisans of Han Nationality also had the possibility to apply the batik to silk fabrics. Although the batik fabrics in these flags are not necessarily made by Han artisans in the Central Plains, the possibility is there. Even if the batik fabric painted by Gaochang craftsmen, also conclude that the Han nationality had already begun to apply the batik craft to silk fabrics, this completed the transformation of the wax printing materials from wool and cotton fab- rics to the silk. In the fourteenth year of the Era Zhenguan (640 A.D.), Gaochang was destroyed by LiShimin, Emperor Taizong of the Tang Dynasty (A.D. 599-649). The Tang Dynasty resettled the military and civilian officials of Gaochang, and the dominant power in Gaochang were moved to Chang'an and Luoyang [6]. So the author feels this the result concurred that the batik technique brought to the Central Plains area is because of inner migration of the dignitaries in Gaochang, which promotes its development here.

Evidence 2: The batik fabrics of Tang Dynasty collected in the Shosoin of Nara. Japan. The Shosoin, Warehouse of Japan during Nara time (A.D. 710-794), had housed daily necessities and precious articles of Shengwu Mikado (A.D. 701-756), which include treasures of Chinese antiques, relics of Western Regions and creations made by Japan in imitation of Chinese cultural relics. Therefore, treasures collected in the Shosoin of Nara provided important material for inquiring into the utensils of the Nara time and the flourishing period of Tang Dynasty. Nowadays, a large number of batik products are stored in the Shosoin of Nara even today, among which the batik folding screen with tree and elephant as well as tree and goat design (figure 2) might be the most famous work. It was drawn from dyeing animal hairs with exquisite patterns and elegant tone [7]. Even as the opinions expressed in "Research for the History of Dyeing and Waving" by scholar Akashi Senjin, the famous screen of the Tang Dynasty was imported into Japan as a precious gift of friendship. Although it cannot be concluded that the batik folding screen with tree and elephant as well as tree and goat design came from the Central Plains of Tang Dynasty, there is no doubt that it was welcomed in here, where as the diplomats would have sent it back to Japan.

Wax printing was always a professional behaviour in manual workshop in the Central Plains of Tang Dynasty. In order to maintain the efficiency of printing

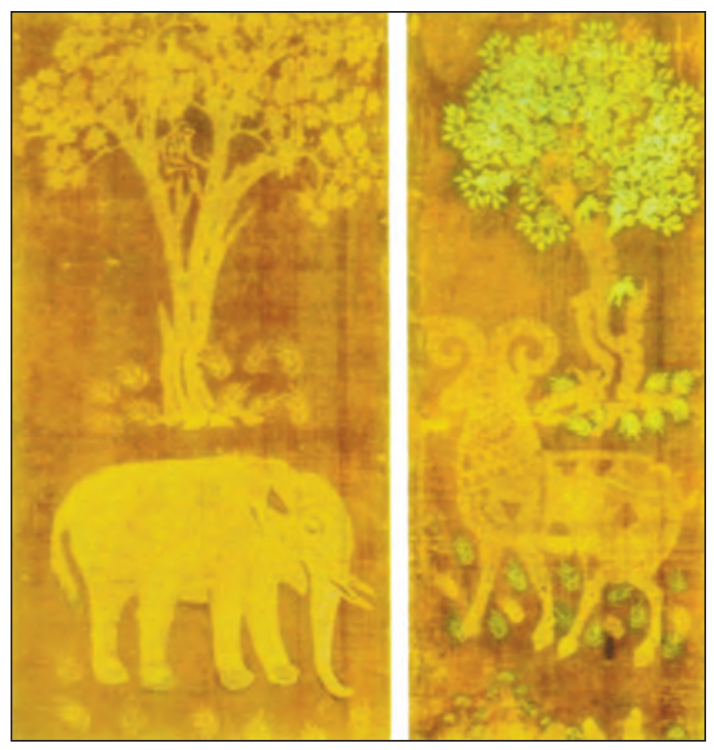

Fig. 2. Batik folding screen with tree and elephant as well as tree and goat 
and guarantee the quality of products, the batik fabrics were mainly produced by the following two methods: i) a small convex template was used to simplify operation; ii) paper type printing was used to further improve production efficiency. The authors think: these two methods are different from manual wax printing or the boards coated with wax of southwest minority area by viewing the mode of production. This suggests that there is little possibility of the batik spread from southwest minority area to the Central Plains. It can also be illustrated that the enormous social demand of the batik fabrics in Tang Dynasty, which standardized production are being obtained to promote its development in the Central Plains of China. People began to popularize application of pattern waxing method after Tang Dynasty. Which laid a foundation for the generation and development of ash resistant dye in the Central Plains area and the batik that replaced by it.

\section{Withered development of the batik in the Central Plains area}

The declining period of the batik in the Central Plains area refers to the period between the two Song Dynasties. At this time, the batik fabric was disappeared almost in Central Plains. Zhou Qufei (A.D. 1135-1189), scholar of Nan Song Dynasty, records Yao people use two pieces of wood with carved patterns to clip the grey cloth, the melted wax goes into the wood patterns, and then dyeing cloth with indigo. The wax is then melted by boiling the cloth to form exquisite pattern [8]. This is particular dyeing method of Yao people the batik was very rare in the Central Plains in the era of Zhou Qufei. Otherwise, he would not have been recorded the, waxing and valerian craft as a kind of odd skill. Exactly what caused the sudden disappearance of batik in Central China is still worth discussing. The author believes it was the sudden extinction of the batik craft in Central Plains that led to the existence of illusion that Chinese batik originated from the southwest minority region.

\section{ANALYSIS ON THE CAUSES OF BATIK EXTINCTION IN THE CENTRAL PLAINS}

Between Northern and Southern Song, the reason for the rapid disappearance of the batik in the Central Plains is generally attributed to the ban on dyeing valerian in the Song Dynasty. It is well known that the extinction of any process is not mainly caused by a certain major factor, but should be considered comprehensively from various factors in the process's internal and external history. The author thinks that the reasons for the rapid disappearance of wax valerian in the Central Plains should be considered from the political environment of Song Dynasty, the economic cost of the batik and the creation of ash resist dye technology.
The Song dynasty dyeing ban was an important political reason for the disappearance of the batik in the folk society

There are strict regulations on the Yufu system in ancient China. The prohibition of dyeing valerian in the civil society is closely related to the Yufu system system.

Such bans were introduced during the Era Xianping of Emperor Zhenzong (998-1003) and Era Tiansheng of Emperor Renzong (1023-1032). The ban imposed during the reign of Emperor Huizong of the Song Dynasty (1082-1135, 1100-1126) was the most severe. According to the records in the historical materials, the dyeing fabric has been widely used in the clothing of the army and guards. In order to strictly separate from the clothing of the common people, the use of dyeing is prohibited to them.

The lack of beeswax in Song Dynasty is an important economic factor to limit the development of the batik

The main raw material for valerian in Central Plains is beeswax. However, beeswax is widely used in Chinese. As early as the Han Dynasty, beeswax was used for the Lighting of royal and noble families [9]. The use of candles can be confirmed in mural painting of Yongtai princess's tomb. There are other important uses for beeswax:

- Used in pharmaceutical production.

- Used in seal of documents. Sealing letters and official documents was an important means to prevent information from leakage in ancient times. It is conceivable that the demand of beeswax is large because of frequent war between the two Song Dynasties.

- Used in cultural trades. Beeswax was an important ingredient in the production of statues and calligraphy mounting. The Song Dynasty, with its thriving culture, must have had a great demand for beeswax.

- Used in all aspects of production and life. In ancient times (including the song dynasty), beeswax was widely used as anti-corrosion and lubricating materials in shoe making, car making, textile and other industries [10]. The beeswax was very widely used in the ancient Central Plains.

Beeswax was very difficult to obtain in the Central Plains of the Song Dynasty, which can be examined from the price of beeswax paid to the court from various places. According to the History of Song Dynasty, Song Hui Yao Ji Gao and Yuan Feng Jiu Yu Zhi, Henan, Shaanxi, Chongqing, Gansu and Anhui all paid less than $50 \mathrm{~kg}$ waxes, and even Pengshui county, Chongqing city, only paid $5 \mathrm{~kg}$ per wax [11]. Beeswax was very expensive, some counties could not even pay $5 \mathrm{~kg}$. Obviously, the beekeeping level in the Tang Dynasty was far lower than that in the Song dynasty. Why did the development of wax resist dye reach its peak in the Tang Dynasty, while gradually disappeared in the Song Dynasty? 
On the one hand, compared with the Song Dynasty, the Tang Dynasty had a vast territory. Even in the early Northern Song Dynasty, its territory was far less than half that of the Tang Dynasty, let alone the Southern Song Dynasty. The areas where beeswax was obtained in the Tang Dynasty were far greater in the Song Dynasty, which could fully compensate for the loss of beekeeping technology lower in the Song Dynasty. According to the New Book of Tang, Gansu, Sichuan, Shaanxi, Hubei, Anhui, Shanxi, Zhejiang, Fujian, Guizhou and other places have paid beeswax as tribute to the imperial court [12]. The Tang Dynasty established 415 Jimi Zhou in the southwest minority regions [13], which includes the major areas of beeswax products. It is not hard to see that the number of beeswax directly obtained in the Central Plains of the Song Dynasty would be much lower than that of the Tang Dynasty.

On the other hand, in the early days of Tang Dynasty, emperor Tai Zong attacked the Turk in the north and the Gaochang in the west, which made the Silk Road run smoothly. At the same time, the Sea Silk Road in the southwest was opened. The strongest period of the Northern Song Dynasty, the north and northwest regions were controlled by the Liao and the Western Xia respectively, and the communication between the land and Central Asia was completely blocked. The southwest regions cannot be effectively controlled and a large-scale war burst in Jiaozhi (Vietnam). At this time in the Northern and Southern Dynasties, only the Sea Silk Road could be used. By comparing the tang and song dynasties, it can be seen that the Tang Dynasty had strong national power, vast territory and smooth traffic between east and west, and the Song Dynasty was the opposite. Therefore, the Song Dynasty had far less means to obtain beeswax from external environments than the Tang Dynasty, which prevented the development of wax resist dye.

The production of ash resist dye in Song Dynasty is an important technical factor for the complete disappearance of the batik

The ash resistant dye is also called Yao ban bu, printing and dyeing by using prepared slurry and resist dyeing technique. Since the song dynasty, it was rising rapidly in Jiangnan regions and is in existence today. According to the Complete Collection of Pictures and Books of Old and New Times, Yao ban bu was originated from Jiading and Anting Towns [14]. From its raw material and technological characteristics, the ash resistant dye is quite suitable for the development in Central Plains. To begin with, the ash resist dye used soybean flours and limes as slurries of resist dye, which is characterized by simple process and low cost. So, it gradually replaced other dyeing and printing technology, and quickly spread from Jiangnan to Jiangbei [15]. In addition, its slurry does not need heating and much simpler than wax resist dye. In the end, due to the stencil frame made for duplicating the blank, it can be produced simultaneously by different printmakers using the same stencil frame, which leads to standardized production. The batik, by contrast, is less likely to achieve this because it needs to heat and use hand drawing. Based on the comparative analysis of the batik and the ash resistant dye in resist dye slurry, and the process characteristics and quality control, the author believes that it is almost a historical necessity for the batik craft to gradually withdraw from people's sight in Central Plains after the production of the ash resistant dye.

\section{CONCLUSIONS}

The results of our research can be summarized as follows:

- The origin of Chinese batik technique can be divided into two types: external afference and Internal self-generating. The origin type of the batik in the Central Plains belongs to the external afferent type, which was introduced from the Indian civilization to the Central Plains through the western regions, and developed a unique dying method in the Central Plains Region. On the contrary, the origin type in the southwest minority region belongs to the type of internal self-generating, which is formed gradually through the migration process of Miao and Yao people and their living environment.

- The development and evolution of the batik in the Central Plain areas have undergone three process: Introduction from the Eastern Han Dynasty to the Southern and Northern Dynasties (A.D. 25-589), wide popularity during the period of Sui-Tang and Five Dynasty (A.D. 581-960) then decline in the Two Song Dynasties (A.D. 960-1279).

- The reasons for the rapid disappearance of wax valerian in the Central Plains should be considered from the internal and external environment and the development trend of dyeing technology. To be specific, the political environment of Song Dynasty, the economic cost of the batik and the creation of ash resist dye technology are the major factor of its demise.

\section{ACKNOWLEDGEMENTS}

The author would like to thank Chinese ministry of education for giving financial support for this study.

\section{REFERENCES}

[1] Zhao, F., Chinese Silk Art History, Chinese Academy of Art Press, Hangzhou, 1992

[2] He, C., Yang, W.B., Province Batik, Soochow University Press, Suzhou, 2009

[3] Xinjiang Uighur Autonomous Region Museum, Culture Unearthed in Xinjiang, Culture Relics Publishing House, Beijing, 1975

[4] Chen, W.J., History of Chinese Textile Science and Technology (Ancient Part), Science Press, Beijing, 1984 
[5] Wang, L., Zhao, F., Study and analysis of existing fabric of Dunhuang banners, In: Dunhuang Research, 2008, 1, $1-9$

[6] Zhang, F.F., Zhang, P., Kingdom Gaochang, China Radio International Press, Beijing, 2013

[7] Bao, Y.Z., Talk on color batik, In: Dyeing \& Finishing, 1985, 3, 25-26

[8] Yu, X.L., Chinese Blue Calico, People's Fine Arts Publishing House, Beijing, 2008

[9] Yang, S.P., Knowledge of the honeybee and technology of bee husbandry in Ancient China, In: Agricultural Archaeology, 1988, 1, 242-251

[10] Ge, F.C., Chen, D.H., Li, Y.F., Time-honoured Changbai bee culture (19) - The Study on beeswax of Chinese Ancient, In: Zhongguo Yangfeng, 1998, 1, 27-28

[11] Zhang, X.Y., The research of bee husbandry in the Song Dynasty, In: Journal of Bee, 2007, 5, 14-16

[12] Guo, R., The research of bee husbandry in the Tang Dynasty, In: The Journal of Chinese Social and Economic History, 2011, 1, 5-10

[13] Fang, T., Discuss in boundary defense thoughts and administrative policy for Chinese southwest borderland in Tang Dynasty, In: Journal of Yunnan Minzu University (Social Sciences), 2001, 2, 51-54

[14] Wu, Y.X., Wu, L.S., The Soul of Gua Jiang Yin Ran - Chinese Blue Calico, Heilongjiang People's Publishing House, Harbin, 2011

[15] Wu, Y.X., Wu, L.S., Blue Allover, China Society Press, Beijing, 2009

\section{Authors:}

LI BIN ${ }^{1}$, ZHAO HONGYAN ${ }^{2}$, LI YIXIAO ${ }^{3}$, JIANG XUEWEI ${ }^{1}$, HONG YU $^{1}$, TAO HUI ${ }^{1}$

${ }^{1}$ Wuhan Textile University, School of Fashion,

Minzu Avenue in Hongshan District, 430073, Wuhan, China

e-mail: libin790121@qq.com,wiiii1i@sina.com

${ }^{2}$ Wuhan Textile University, Hubei Research Center of Intangible Cultural Heritage, Minzu Avenue in Hongshan District, 430073, Wuhan, China

${ }^{3}$ Institute of Textiles\&Clothing, The Hong Kong Polytechnic University, Hong Kong, China

e-mail: 953592363@qq.com

Corresponding authors:

ZHAO HONGYAN

e-mail: 530417418@qq.com

JIANG XUEWEI

e-mail: jxw21981@163.com

TAO HUI

e-mail: 932678733@qq.com 


\title{
The effects of online marketing on financial performance in the textile industry
}

DOI: $10.35530 / \mathrm{IT} .071 .03 .1826$

MIHAI CRISTIAN ORZAN

MARGARETA STELA FLORESCU

OCTAV IONUT MACOVEI

\author{
SORIN BURLACU \\ OLGUTA ANCA ORZAN
}

\section{ABSTRACT - REZUMAT}

\section{The effects of online marketing on financial performance in the textile industry}

Although Romania has an Internet penetration rate of $73.8 \%$, over the world average, below the European Union average of $85.2 \%$, Romanian Internet users ranked $28^{\text {th }}$ in online shopping, the lowest position in EU, while the Romanian enterprises are the least digital in the EU ranking on the lowest positions in using social media and e-commerce. The aim of this paper is to examine the impact of using online marketing tools in the development and implementation of marketing strategies and their impact on organizational performance in the textile industry. We propose an empirical model, rooted in an in-depth survey of over 897 Romanian organizations acting on the textile industry market (production, distribution or retail), which gives us a general overview of antecedents of online marketing success and its impact on organizational performance.

Keywords: e-commerce, online strategy, online distribution, crowdsourcing, marketing metrics

\section{Influența instrumentelor de marketing online asupra performanței financiare a organizațiilor din industria textilă}

Cu toate că, în România, internetul are o rată de penetrare de $73,8 \%$, peste media mondială, dar sub media de $85,2 \%$ a ţărilor din Uniunea Europeană, utilizatorii de internet români s-au clasat pe locul 28 la cumpărăturile online, ultima poziție la nivelul UE, în timp ce întreprinderile românești sunt cele mai puțin digitalizate la nivelul UE, fiind pe ultimul loc în utilizarea mediilor sociale şi a comerțului electronic. Scopul lucrării este de a analiza impactul utilizării instrumentelor de marketing online în elaborarea și implementarea strategiilor de marketing și asupra performanței organizaționale pentru întreprinderile ce activează în industria textilă. Ca urmare a studiului, s-a dezvoltat un model empiric, pe baza unui sondaj cu 897 de respondenţi din organizații românești, care acționează pe piața industriei textile (producție, distribuție sau vânzare cu amănuntul) și care ne oferă o imagine de ansamblu bine definită a succesului marketingului online și a impactului său asupra performanței organizaționale.

Cuvinte-cheie: e-comerţ, strategie online, distribuţie online, crowdsourcing, indicatori ai performanţei

\section{INTRODUCTION}

$21^{\text {st }}$ century is the age of globalization and information society. The interconnections between people, people and organizations and between organizations and organizations are ever increasing. The Internet plays a key role in this evolution of the society, being the word and the key technology of the last two decades. The world Internet penetration rate increase since the year 2000 with $1100 \%$ [1]. More and more word companies and organizations have begun to appreciate and benefit from the advantages that the online environment brings to their marketing activity, regardless of its nature, a trend that also manifests in Romania. The Internet penetration rate in Romania is $73.5 \%$, over the world average but below the European Union average of $85.2 \%$ [1].

A study conducted by Śledziewska et al. for Google [2] showed that Romania is the least digital country in the European Union ranking $28^{\text {th }}$ in the Digital Economy and Society - DESI Index, the last place, revealing problems that hold back the Romanian business sector. Furthermore, Romanian ranked $27^{\text {th }}$, regarding the level of digital skills of the society, outperforming only Bulgaria. Romanian Internet users ranked $28^{\text {th }}$ in online shopping and $27^{\text {th }}$ position in users engaging in online services and online banking. Also, the level of development of Digital Public Services (like e-government) is the second lowest in the European Union (27 $7^{\text {th }}$ place).

The same study shows that Romanian companies and organizations are not using social media, ranking the lowest in the UE at this chapter (28 ${ }^{\text {th }}$ place), and do not take full advantage of other digital tools [2]. Regarding the use of electronic information sharing software, like management tools, Romanian organizations also rank on some of the lowest position: $24^{\text {th }}$ place for software like ERP software and $26^{\text {th }}$ for cloud computing services. Furthermore, Romanian companies and organizations are not engaged in ecommerce, Romania placing on lower positions at 
criteria like the share of firms selling online $\left(24^{\text {th }}\right.$ place), turnover share (24 $4^{\text {th }}$ place) and cross-border selling $\left(28^{\text {th }}\right.$ place).

In conclusion, Romanian enterprises are the least digital in the EU and these country's problems with digital transformation affect the business environment. These researches show a lot about the maturity of the online business environment in Romania, which has a great development potential, but much to reach the level of maturity of the most economically developed European states. The aim of this paper is to examine the impact of designing online marketing strategies and implementing online marketing techniques on the financial and marketing performance of Romanians' textile industry organizations in order to explain and predict their intention to continue using online marketing tools to achieve their strategic objectives.

A unique econometric model has been proposed for this study in order to analyze the influence of using online marketing techniques in implementing marketing strategies on the textile industry organizations' financial and marketing performance and their intention to continue using online marketing strategies and techniques.

\section{RESEARCH MODEL AND HYPOTHESES}

The development of online environment implies the adoption of marketing tools in order to achieve the short, medium or long-term strategic objectives. The results of adopting online marketing tools should be reflected in the company's marketing performance and implicitly in their financial performance, including reputation, market share, number of clients, customer loyalty. Thus, some of the research questions we try to answer include:

1. How is the use of online marketing techniques and tools in implementing marketing strategies reflected in the textile industry organization's marketing and financial performance?

2. Can it be said that using online marketing techniques in implementing marketing strategies, will the textile industry organization increase its reputation, market share or number of clients?

3. Furthermore, the mere adoption of online marketing tools does imply the continuity of this decision? As a result, we are proposing the following hypotheses:

- Hypothesis 1: The frequency of using online marketing techniques has a direct and positive effect on the frequency of using online marketing techniques.

Online marketing techniques can be used to implement marketing strategies for the four marketing mix elements: price, product, place, and promotion [3]. Thus, we state that:

- Hypothesis 2-5: The frequency of using online marketing techniques has a direct and positive effect on implementing product (H3-price, H4-place, H5-promotion) marketing strategies.
The link between the use of business strategies and the textile industry organizations' financial performance has been described and verified in many studies, most frequently on the link between Porter's generic strategies used by textile industry organizations and their impact on the financial performance, moderated by the organization's internal and external environment [4-6]. There are many adaptations of this model, one of them regarding the influence of using strategies on the success of online marketing [7]. We hereby formulate the $\mathrm{H} 6-\mathrm{H} 9$ hypotheses of the research:

- Hypotheses 6-9: The frequency of using online marketing techniques in implementing product (H7 - price, H8 - place, H9 - promotion) marketing strategies has a direct and positive effect on textile industry organizations' marketing performance.

The marketing performance of the textile industry organization, which combines aspects of increasing the organization's reputation, market share, number of customers and their loyalty, is determined to a lesser or greater extent by the use of online marketing tools, which underpin the implementation of marketing strategies in the online environment.

- Hypothesis 10: The frequency of using online marketing techniques on implementing marketing strategies has a direct and positive effect on textile industry organizations' marketing performance.

- Hypothesis 11: The frequency of using online marketing tools on implementing marketing strategies has a direct and positive effect on textile industry organizations' marketing performance.

A textile industry organization's marketing performance reflects its financial performance: increasing turnover, sales revenue, profits, and leads. In other words, the benefits of using online marketing tools in implementing marketing strategies reflect in the organizations' financial performance [8]:

- Hypothesis 12: Textile industry organizations'marketing performance has a direct and positive effect on organizations' financial performance.

However, developing and implementing online marketing strategies and techniques entails costs for the organization that adopts them. First, it is about spending with qualified staff, because not all employees have knowledge, skills or abilities to develop or implement an online marketing strategy or technique. Second, the development and implementation of online marketing techniques involve the use of technological equipment [9]. The continued use of these techniques involves maintenance costs. All these costs reflect in the company's financial performance and the profit will change:

- Hypothesis 13: The costs of implementing online marketing techniques have a direct and positive effect on textile industry organizations' financial performance.

Relative advantages are a concept taken from Diffusion of Innovation Theory [10]. There is no general rule on the components of the relative advantage 
concept. These depend on the perceptions and specific needs of a user group [10].

Thus, in the present research, the relative advantages of using online marketing strategies and techniques can be reflected in the textile industry organization's financial performance. The extent to which marketers perceive the relative benefits of using online marketing tools to achieve strategic goals depends not only on the adoption rate [10] but also on the continuity of intent [11].

- Hypothesis 14: Textile industry organizations' financial performance has a direct and positive effect on textile industry organizations' intention to continue using online marketing techniques.

Simple adoption of online marketing strategies and techniques does not imply continuity. Marketing decision makers can always give up their use. The basis for this assertion is found in the Theory of Dissemination of Innovation [10], which states that the adoption of innovation can result either in continuity or discontinuity.

The Expectation Confirmation Theory [12] places satisfaction as the main predictor of the behavioural continuity intention. This causal link between satisfaction and intention was validated for individual behaviour in the case of intention to continue shopping online [3], and will be adapted to the study of textile industry organizational behaviour:

- Hypothesis 15: Satisfaction of using online marketing techniques has a direct and positive effect on textile industry organizations' intention to continue using online marketing techniques.

However, decision-makers' satisfaction with their decision to use online marketing strategies and techniques is determined by certain factors. The Expectation Confirmation Theory [12] postulates product performance as a key predictor of the extent to which customers are satisfied with choosing a product. In a similar way, we will assume that the decision makers will be satisfied with their decision to use online marketing tools to the extent that they perceive a higher level of financial performance due to the development and implementation of online marketing strategies and techniques:

- Hypothesis 16: Textile industry organizations' financial performance has a direct and positive effect on organizations' satisfaction of using online marketing techniques.

The textile industry organizations operate in accordance with the evolution of the economic and social environment, which implies the adaptation of the enterprise's activity to the external environment. The company meets customers, the most important component of organization's micro-business. Customers can be the ones who put pressure on the business to adopt online marketing tools or techniques. To substantiate the direct and positive effects of these pressures, we have resorted to the study of the Theory of Behaviour Planned [13], which take into account the social component in the study of the behavioural intent of individuals.

- Hypothesis 17: The level of external pressure has a direct and positive effect on textile industry organizations' intention to continue using online marketing techniques.

Adoption and continued use of information technology closely link to the concept of compatibility. Compatibility is a concept specific to the Diffusion of Innovation Theory [10] and represents "the degree to which innovation is perceived as consistent with past values, experiences, and needs of potential users".

Similarly, the variable compatibility was built in the present research. Compatibility implies a concordance between the overall purpose, goals, values and organizational culture of the enterprise, and the use of online marketing strategies and techniques.

- Hypothesis 18: The compatibility with using online marketing techniques has a direct and positive effect on textile industry organizations' intention to continue using online marketing techniques.

\section{METHODOLOGY, DATA ANALYSIS AND RESULTS}

The survey instrument was pretested on a sample of 60 respondents and the questions were adjusted after the reliability and internal consistency analysis. The model contains two types of variables: six variables measured on a frequency scale and seven variables are measured on a 7-point Likert scale ranging from 1 - Strongly disagree to 7 - Strongly agree as shown in figure 1.

The target population consists of all companies and textile industry organizations with a presence in the online environment registered in the Romanian National Trade Register Office. The resulted sample size statistically representative for a confidence interval of $95 \%$ and an error of $+/-3$ has 874 respondents. A survey was conducted on a sample of 944 Romanian textile industry organizations, with 893 entries validated and subjected to further analysis.

In the research, the four steps [14] and double phasing of the analysis process [15] were applied. First, the reliability and internal consistency analysis for variables measured with Likert scales followed that the items corresponding to each construct have a Cronbach's Alpha value over 0.7 [16], the items being accurate and describing well the latent construct (table 1). Next, the average variance extracted (AVE) values from table 1 , which are all over 0.5 , show constructs' good convergent validity and the square roots of AVE are higher than any other correlation among latent variables (table 1), resulting a good discriminant validity [16].

\section{RESULTS AND DISCUSSION}

The proposed research model was analyzed using WarpPLS 6.0 with the bootstrap resampling method. 


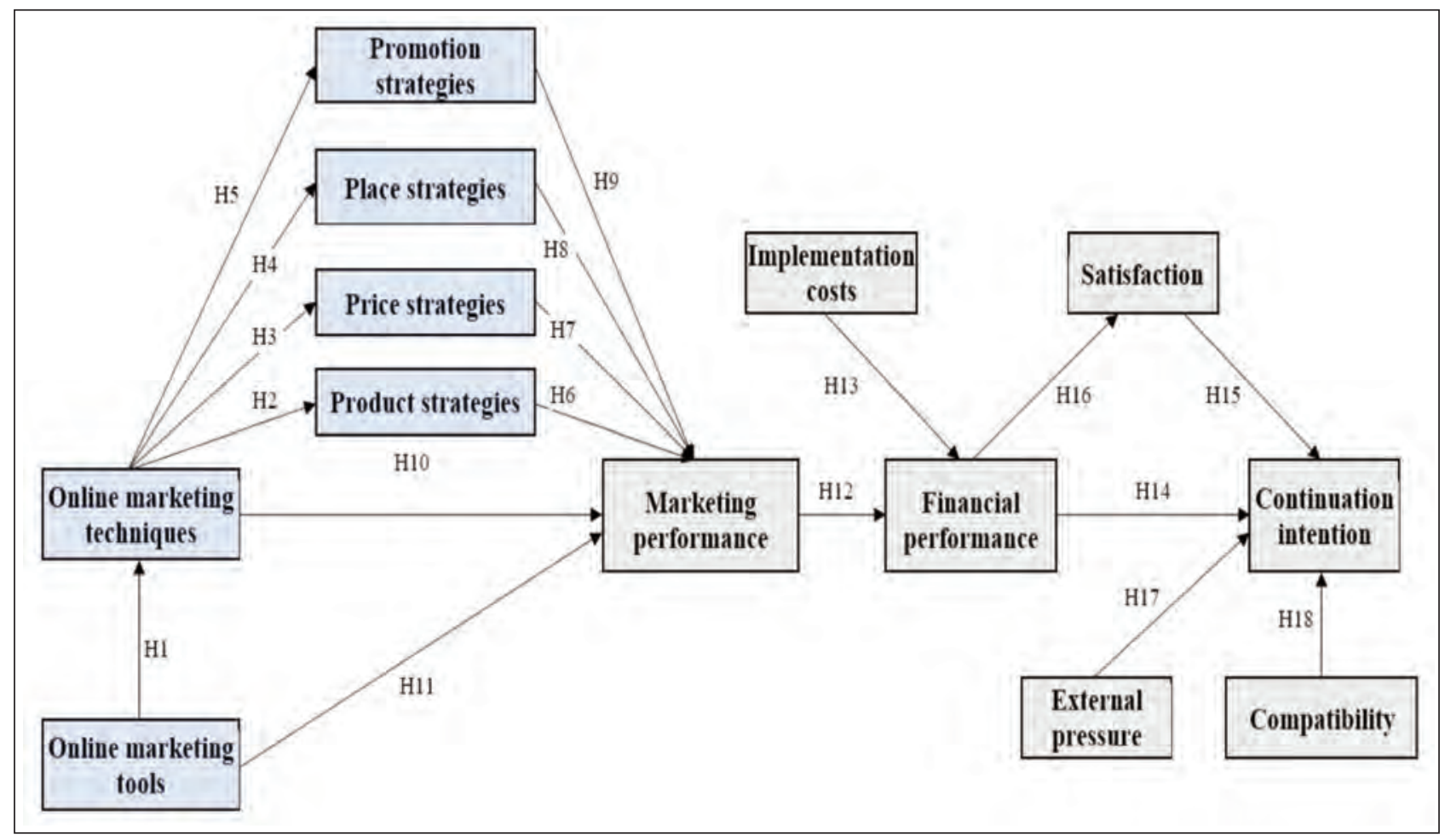

Fig. 1. The research model: the performance model of using online marketing techniques

Table 1

\begin{tabular}{|l|c|c|c|c|c|c|c|c|c|}
\hline \multicolumn{10}{|c|}{ RELIABILITY AND VALIDITY ANALYSIS } \\
\hline \multicolumn{1}{|c|}{ Items } & Alpha & AVE & $\mathbf{1}$ & $\mathbf{2}$ & $\mathbf{3}$ & $\mathbf{4}$ & $\mathbf{5}$ & $\mathbf{6}$ & $\mathbf{7}$ \\
\hline 1. MK_PERF & 0.897 & 0.710 & $\mathbf{0 . 8 4 3}$ & 0.643 & -0.282 & 0.503 & 0.551 & 0.462 & 0.496 \\
\hline 2. FIN_PERF & 0.929 & 0.779 & 0.643 & $\mathbf{0 . 8 8 3}$ & -0.36 & 0.522 & 0.698 & 0.499 & 0.533 \\
\hline 3. COSTS & 0.794 & 0.629 & -0.282 & -0.36 & $\mathbf{0 . 7 9 3}$ & -0.298 & -0.268 & -0.283 & -0.292 \\
\hline 4. SATISFAC & 0.911 & 0.790 & 0.503 & 0.522 & -0.298 & $\mathbf{0 . 8 8 9}$ & 0.645 & 0.572 & 0.502 \\
\hline 5. INTENTIO & 0.899 & 0.832 & 0.551 & 0.698 & -0.268 & 0.645 & $\mathbf{0 . 9 1 2}$ & 0.587 & 0.589 \\
\hline 6. COMPATIB & 0.932 & 0.772 & 0.462 & 0.499 & -0.283 & 0.572 & 0.587 & $\mathbf{0 . 8 7 8}$ & 0.502 \\
\hline 7. EXT_PRES & 0.887 & 0.751 & 0.496 & 0.533 & -0.292 & 0.502 & 0.589 & 0.502 & $\mathbf{0 . 8 6 6}$ \\
\hline
\end{tabular}

Note: Square roots of AVE's shown on diagonal

Figure 2 shows the model's estimates of $\beta$ path coefficients with their probability values and the $R^{2}$ coefficients. Estimates show that textile industry organizations' marketing performance (MKPERF) variance is explained by its six predictors measured on frequency scale in a proportion of $64 \%$, which is very good, the main predictor being the frequency of using online marketing techniques (TECHNIC), with a beta coefficient of 0.30 , followed by the frequency of using online marketing techniques in implementing promotion marketing strategies with a beta path coefficient of 0.22 .

Textile industry organizational financial performance (FINPERF) variable variance is explained by its two predictors variance in a percentage of $47 \%$, the strongest predictor being textile industry organization marketing performance (MKPERF), as expected (beta $=0.57$ ), while the costs of implementing online marketing techniques also manifest an influence of only 0.22 , suggesting that textile industry organizations don't perceive the costs as a strong obstacle in using online marketing techniques. The third most important dependent variable's variance, intention to continue using online marketing techniques (INTENTIO) is explained in a proportion of $63 \%$ by the variance of its four predictors, the strongest being financial performance (FINPERF, beta $=0.38$ ), followed by the mediating variable adapted for the context of business, satisfaction of using online marketing techniques (SATISFAC, beta $=0.26$ ).

All ten models fit and quality indices from table 2 have very good or excellent values and probabilities. The AVIF index, which is the most important measure of the model fit, is 1.224 , under the ideal limit of 3.3 , while the ARS index is 0.291 for a $p<0.001$ [18]. The third most important index, APC, is 0.232 for a $p<0.001$ [18].

In conclusion, our findings validated the proposed model and its research hypotheses. 


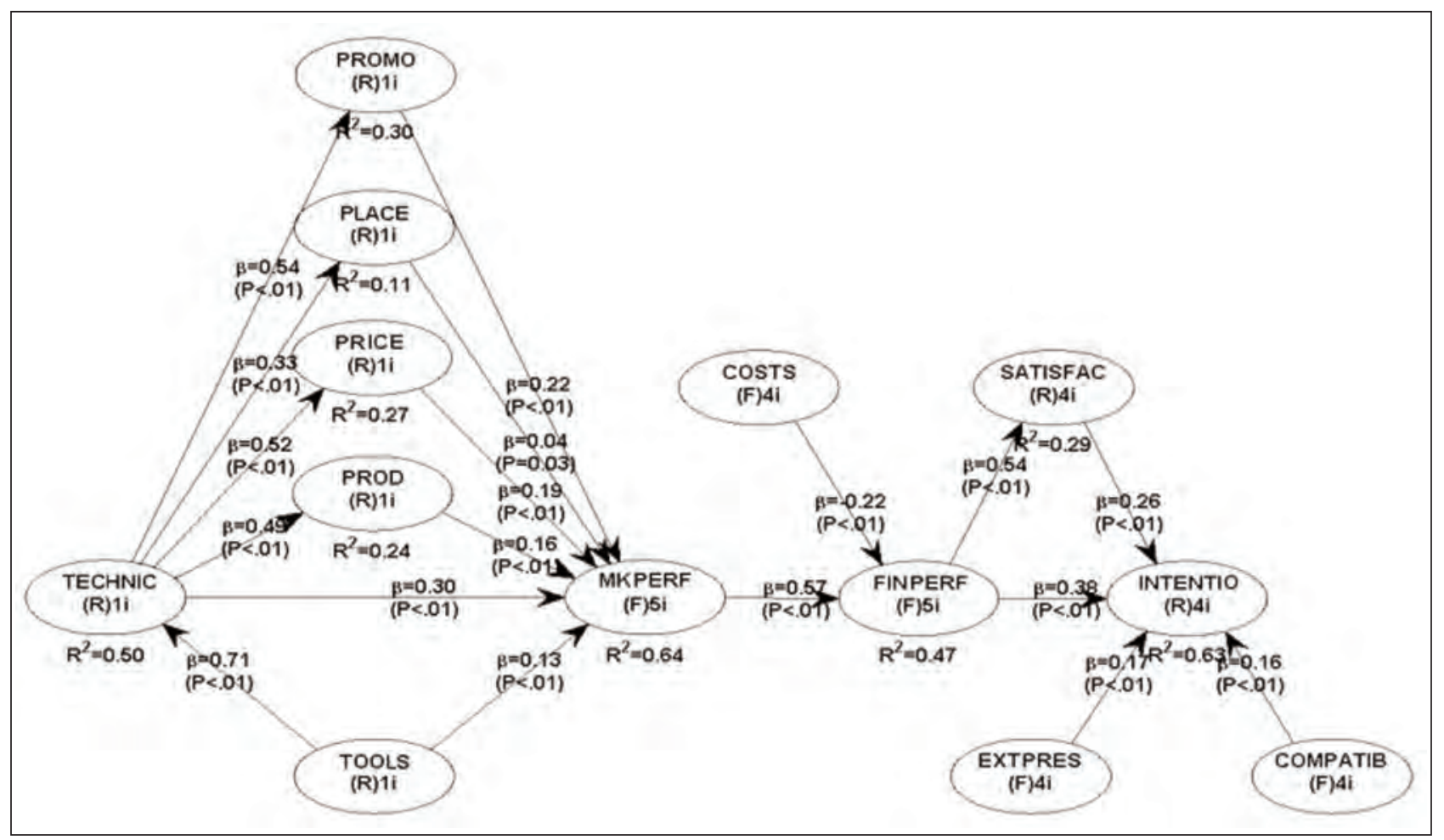

Fig. 2. Estimated model using PLS Analysis

Table 2

MODEL FIT AND QUALITY INDICES (COMPUTED WITH WARPPLS 6.0)

\begin{tabular}{|l|l|}
\hline \multicolumn{1}{|c|}{ Indices } & \multicolumn{1}{c|}{ Criterion } \\
\hline Average path coefficient $(\mathrm{APC})=0.232$ & $\mathrm{P}<0.001$ \\
\hline Average R-squared (ARS) $=0.291$ & $\mathrm{P}<0.001$ \\
\hline Average adjusted R-squared (AARS) $=0.453$ & $\mathrm{P}<0.001$ \\
\hline Average block VIF (AVIF) $=1.224$ & acceptable if $\leq 5$, ideally $\leq 3.3$ \\
\hline Average full collinearity VIF (AFVIF) $=1.879$ & acceptable if $\leq 5$, ideally $\leq 3.3$ \\
\hline Tenenhaus GoF $(\mathrm{GoF})=0.487$ & $\begin{array}{l}\text { small } \geq 0.1 \\
\text { medium } \geq 0.25 \\
\text { large } \geq 0.36\end{array}$ \\
\hline Sympson's paradox ratio (SPR) $=1.000$ & acceptable if $\geq 0.7$, ideally $=1$ \\
\hline R-squared contribution ratio $(\mathrm{RSCR})=1.000$ & acceptable if $\geq 0.9$, ideally $=1$ \\
\hline Statistical suppression ratio $(\mathrm{SSR})=1.000$ & acceptable if $\geq 0.7$ \\
\hline $\begin{array}{l}\text { Nonlinear bivariate causality direction ratio } \\
\text { (NLBCDR) }=1.000\end{array}$ & acceptable if $\geq 0.7$ \\
\hline
\end{tabular}

adapted to individual consumer behaviour specific metrics, such as satisfaction, intention to continue the use, compatibility or normative behaviour.

The methodological implications consist mainly in proposing, testing and validating measurement scales such as the financial and marketing performance of textile industry organizations, strategy implementation costs, textile industry organizations' compatibility issues implementing online marketing techniques and external pressure felt by textile industry organizations. These metrics proved to be reliable and can be used in future research.

\section{IMPLICATIONS, CONCLUSIONS AND FURTHER RESEARCH}

In this study, we studied the positive effects of online marketing tools on marketing performance in an emerging economy, as well as their implications on textile industry organizational financial performance. Furthermore, we measured a synergetic effect of online marketing techniques on textile industry organization's marketing and financial performance.

The theoretical implications include introducing new relationships between the thirteen variables adapted for the case of using online marketing techniques by companies and textile industry organizations, as well as novel ways of measuring marketing performance,
The managerial implications consist in establishing the direct and positive effect of the use of online marketing tools in achieving strategic marketing objectives on the marketing and financial performance of the textile industry organizations. From these relationships we can observe that textile industry organizations which are not currently using online marketing tools in implementing their marketing strategies have poor marketing and financial performance and need to adopt them as soon as possible in order to be competitive and survive in the future.

Future research could analyse the relationship between the usage of brand and loyalty strategies in 
the online environment and the textile industry organization's financial performance.

\section{ACKNOWLEDGEMENTS}

This research was supported financially by the project CNFIS-FDI-2018-0582 - Supporting Excellence Research within The Bucharest University of Economic Studies in the context of the principles of sustainable development and open research. 6. Supporting field research excellence in universities Beneficiary: The Bucharest University of Economic Studies.

\section{REFERENCES}

[1] Internet World Stats, Usage and Population Statistics, 2020, Available at: http://www.internetworldstats.com/ stats.htm [Accessed March 2020]

[2] Śledziewska, K., Włoch, R., Akhvlediani, T., Gyódi, K., Zięba, D., Transformation of Small and Medium Enterprises in ROMANIA, CDELab UW - Commissioned by Google, 2020, Available online at: https://www.delab.uw. edu.pl/pl/digital-transformation-of-small-and-medium-enterprises-in-romania/ [Accessed March 2020]

[3] Orzan, G., Iconaru, C., Popescu, I.C., Orzan, M., Macovei, O.I., PLS-based SEM analysis of apparel online buying behavior. The importance of eWOM, In: Industria Textila, 2013, 64, 6, 362-367

[4] Kim, E., Nam, D., Stimpert, J.L., The applicability of Porter's generic strategies in the digital age: Assumptions, conjectures, and suggestions, In: Journal of Management, 2020, 569-589

[5] Allen, R.S., Helms, M.M., Linking strategic practices and textile industry organizational performance to Porter's generic strategies, In: Business Process Management Journal, 2006, 433-454

[6] Georganta, Z., Vogiatzi, M., The Effects of Information and Communication Technologies on E-Business Performance: Designing a Path Analysis Framework, In: Journal of Information Technology Impact, 2010, 10, 3, 137-160

[7] Elliot, R., Rupping, P.T., The Influence of Porter's Generic Strategies on the Success of Internet Marketing, In: Australian \& New Zealand Marketing Academy Conference, 2004, 1-9

[8] Ceptureanu, E.G., Ceptureanu, S.I., Orzan, M.C., Bordean, O.N, Rădulescu, V., Empirical Study on Sustainable Opportunities Recognition. A Polyvinyl Chloride (PVC) Joinery Industry Analysis Using Augmented Sustainable Development Process Model, In: Sustainability, 2019, 9, 10, 420-427, https://doi.org/10.3390/su9101779

[9] Tuta, M., Zara, I.A., Orzan, G., Purcărea, V.L, Orzan, O.A., Competitive Intelligence: An Enhancement to Business Intelligence, In: Economic Computation and Economic Cybernetics Studies and Research, 2014, 48, 2, 151-161, https://doi.org/10.3390/su9101779

[10] Rogers, E.M., Diffusion of Innovations, The Free Press Publishing, New York, 1995

[11] Bhattacherjee, A., Premkumar, G., Understanding changes in belief and attitude toward information technology usage: A theoretical model and longitudinal test, In: MIS Quarterly, 2004, 229-254

[12] Oliver, R.L., A Cognitive Model of the Antecedents and Consequences of Satisfaction Decisions, In: Journal of Marketing Research, 1980, 460-469

[13] Ajzen, I., The Theory of Planned Behavior", In: Organizational Behavior and Human Decision Processes, 1991, 179-211

[14] Morteza, C., Norzima, B.Z., Faieza, A.A., The Interactive Model of User Information Technology Acceptance and Satisfaction in Small and Medium-sized Enterprises, In: European Journal of Economic, Finance and Administrative Sciences, 2010, 19, 181-211

[15] Kline, R.B., Principles and Practice of Structural Equation Modeling (3rd edition), The Guilford Press, New York, USA, 2011

[16] Kock, N., WarpPLS User Manual: Version 6.0. Laredo, TX: Script Warp Systems, 2017

\section{Authors: \\ MIHAI CRISTIAN ORZAN ${ }^{1}$, MARGARETA STELA FLORESCU², OCTAV IONUT MACOVEI ${ }^{1}$, SORIN BURLACU ${ }^{2}$, OLGUTA ANCA ORZAN ${ }^{3}$}

${ }^{1}$ Bucharest University of Economic Studies, Faculty of Marketing, Bd. Dacia, no. 41, 010374, Bucharest, Romania e-mail: octav.macovei@yahoo.com

${ }^{2}$ Bucharest University of Economic Studies, Faculty of Administration and Public Management,

Piața Romana, no. 6, 010374, Bucharest, Romania e-mail: sburlacu@man.ase.ro

${ }^{3}$ Emergency University Hospital Elias, Bd. Mărăşti, no. 17, 011461, Bucharest, Romania e-mail: orzan@yahoo.com

Corresponding author:

MARGARETA STELA FLORESCU

e-mail: margareta.florescu@ari.ase.ro 
Industria Textila magazine is an international peerreviewed journal published by the National Research \& Development Institute for Textiles and Leather - Bucharest, in print editions.

Aims and Scope: Industria Textila journal is addressed to university and research specialists, to companies active in the textiles and clothing sector and to the related sectors users of textile products with a technical purpose.

\section{Submission of Manuscripts}

Please read the guidelines below then visit the Journal's submission site manuscriptmanager.net/it or the button Submit manuscript to upload your manuscript. Please note that manuscripts not conforming to these guidelines may be returned.

Copyright Transfer Agreement must be signed and returned to our Editorial Office by mail, as soon as possible, after the preliminary acceptance of the manuscript. By signing this agreement, the authors warrant that the entire work is original and unpublished, it is submitted only to this Journal and all the text, data, Figures and Tables included in this work are original and unpublished, and have not been previously published or submitted elsewhere in any form. Please note that the reviewing process begins as soon as we receive this document. In the case when the paper has already been presented at a conference, it can be published in our journal only if it has not been published in a generally available conference materials; in such case, it is necessary to give an appropriate statement placed in Editorial Notes at the end of the article.

Manuscripts submitted are check against plagiarism with Anti-plagiarims System. Manuscripts of the following types are accepted:

Research Papers - An original research document which reports results of major value to the Textile Community

Book Reviews - A brief critical and unbiased evaluation of the current book, normally invited by the Editor.

Manuscripts shall be submitted in English in single-spaced typing, A4 paper, Arial, margins $2 \mathrm{~cm}$ on all sides, under electronic version in Word for Windows format.

The volume of the submitted papers shall not exceed 8 pages (including the bibliography, abstract and key words), typescript pages including tables, figures and photographs.

All articles received are reviewed by minimum two reviewers, renowned scientist and considered expert in the subject the article concerns, which is appointed by the editorial board. After the article has been accepted, with the completions and the modifications required by the reviewers or by the editorial staff, it will be published.
The submission of the above-mentioned papers is by all means the proof that the manuscript has not been published previously and is not currently under consideration for publication elsewhere in the country or abroad.

There may also be published papers that have been presented at national or international scientific events, which have not been published in volume, including the specification related to the respective event.

The articles assessed as inappropriate by the reviewer or by the editorial staff, concerning the subject matter or level, shall not be published.

The manuscript shall be headed by a concise title, which should represent in an exact, definite and complete way the paper content.

The manuscript shall also be headed by complete information about the author(s): titles, name and forename(s), the full name of their affiliation (university, institute, company), department, city and state, as well as the complete mailing address (street, number, postal code, city, country, e-mail, fax, telephone).

Tables and figures (diagrams, schemes, and photographs) shall be clear and color, where possible.

The photographs shall be sent in original format (their soft), or in JPEG or TIF format, having a resolution of at least 300 dpi.

All tables and figures shall have a title and shall be numbered with Arabic numerals, consecutively throughout the paper and referred by the number in the text.

Generally, symbols and abbreviations shall be used according to ISO 31: Specifications for quantities, units and symbols. SI units must be used, or at least given comprehensive explanations or their equivalent.

Cited references shall be listed at the end of the paper in order of quotation and contain: for a paper in a periodical - the initials and surname of the author(s), title of journal and of the article, year and number of issue, number of volume and page numbers; for a book - the initial and surname of the author(s), full name of the book, publisher, issue, place and year of publishing, and the pages cited; for patents - the initial and surname of the author(s), the title, the country, patent number and year. It is preferable not to use sites as references.

[1] Hong, Y., Bruniaux, P., Zhang, J., Liu, K., Dong, M., Chen, Y., Application of 3D-to-2D garment design for atypical morphology: a design case for physically disabled people with scoliosis, In: Industria Textila, 2018, 69, 1, 59-64, http://doi.org/10.35530/IT.069.01.1377

Authors are requested to send an abstract of the paper, preferably no longer than 250 words and a list of 5-6 key words (preferably simple, not compound words, in alphabetical order). 